\title{
Barkás vesszőként alkalmazható hazai Salix taxonok termesztésbe vonása és posztharveszt kezelése
}

\section{DOKTORI ÉRTEKEZÉS}

\author{
Treerné Windisch Mária
}

Készült a Budapesti Corvinus Egyetem, Kertészettudományi Kar Dísznövénytermesztési és Dendrológiai Tanszékén

Budapest

2014 


\section{A doktori iskola}

megnevezése:

tudományága:

vezetője:

Témavezető:
Kertészettudományi Doktori Iskola

Növénytermesztési és kertészeti tudományok

Dr. Tóth Magdolna

egyetemi tanár, DSc

BUDAPESTI CORVINUS EGYETEM, Kertészettudományi Kar,

Gyümölcstermő Növények Tanszék

Tillyné dr. Mándy Andrea

egyetemi docens, CSc

BUDAPESTI CORVINUS EGYETEM, Kertészettudományi Kar,

Dísznövénytermesztési és Dendrológiai Tanszék

A jelölt a Budapesti Corvinus Egyetem Doktori Szabályzatában elöírt valamennyi feltételnek eleget tett, az értekezés mühelyvitájában elhangzott észrevételeket és javaslatokat az értekezés átdolgozásakor figyelembe vette, ezért az értekezés nyilvános vitára bocsátható.

Dr. Tóth Magdolna, DSc

Az iskolavezető jóváhagyása
Tillyné dr. Mándy Andrea, CSc

A témavezető jóváhagyása 
A Budapesti Corvinus Egyetem Élettudományi Területi Doktori Tanács 2013. december 4-i határozatában a nyilvános vita lefolytatására az alábbi bíráló Bizottságot jelölte ki:

\section{BÍRÁLÓ BIZOTTSÁG:}

Elnöke

Rimóczi Imre, DSc, Budapesti Corvinus Egyetem

\section{Tagjai}

Hegedüs Attila, PhD, Budapesti Corvinus Egyetem

Neményi András, PhD, Szent István Egyetem

Simon Gergely, PhD, Budapesti Corvinus Egyetem

Sütöriné Diószegi Magdolna, PhD, Budapesti Corvinus Egyetem

Opponensek

Máthé Ákos, DSc, Nyugat-Magyarországi Egyetem

Szafián Zsolt, PhD, Prenor

Titkár

Sütöriné Diószegi Magdolna, PhD, Budapesti Corvinus Egyetem 


\section{TARTALOMJEGYZÉK}

1.1 A HAZAI BARKAFÜZEK, MINT VÁGOTT VIRÁGOK (BARKÁS VESSZŐK) ALKALMAZÁSÁNAK LEHETŐSÉGEI ÉS PROBLÉMÁl .............1

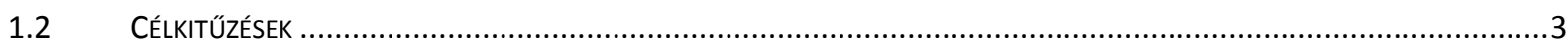

2

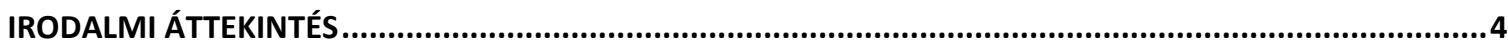

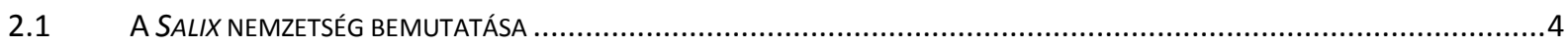

2.1.1 A Salix nemzetség általános jellemzése és taxonómiája .................................................................

2.1.2 Hazánkban öshonos fontosabb barkás Salix fajok ..........................................................................

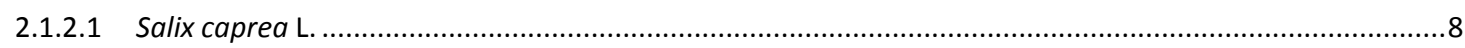

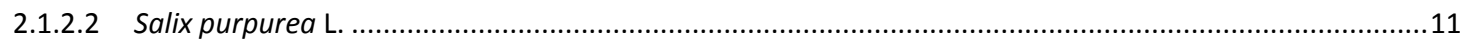

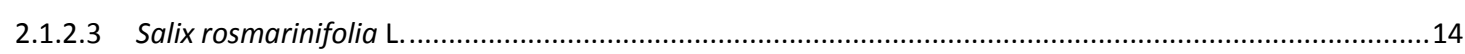

2.1.2.4 Magyarországon honos, barkás vessző termesztésre alkalmas egyéb füz fajok ........................................16

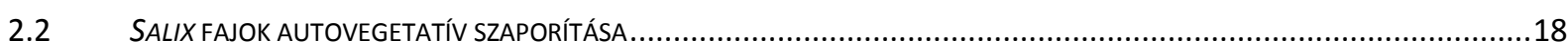

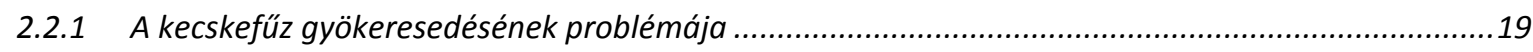

2.2.2 Barkás vesszök termesztése …………………...................................................................19

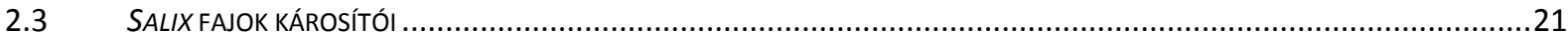

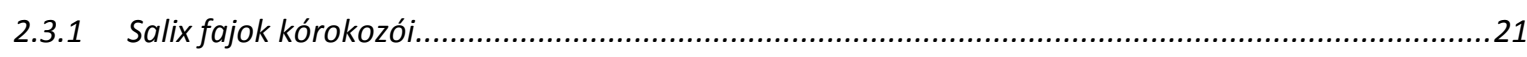

2.3.1.1 Levél- és hajtáskórokozók.......................................................................................................21

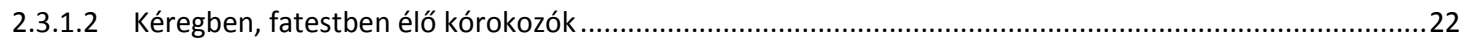

2.3.1.3 Törzs- és tőkorhasztó gombák .............................................................................................2

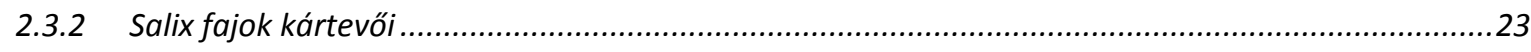

2.4 NYÍLASZTÁS - A NÖVÉNYEK NYUGALMI ÁLLAPOTÁRA HATÓ TÉNYEZŐK...........................................................25

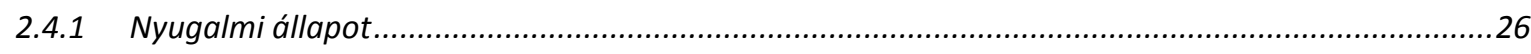

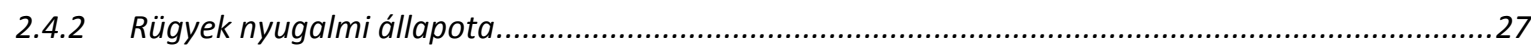

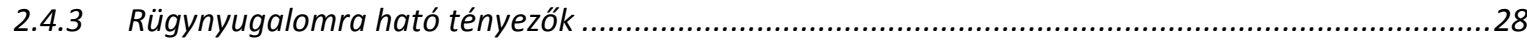

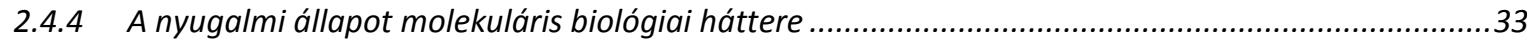

2.5 VÁGOTT VIRÁGOK ÉS VÁGOTT ZÖLDEK HOSSZABB TÁVÚ TARTÓSÍTÁSÁNAK LEHETŐSÉGEI..............................................35

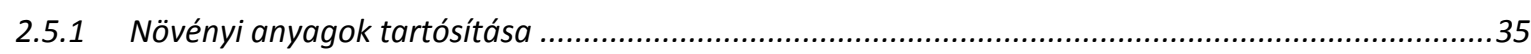

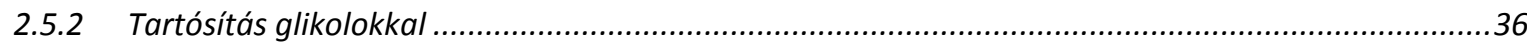

2.5.2.1 Növényi anyagok tartósitására használt fóbb glikolok.........................................................................37

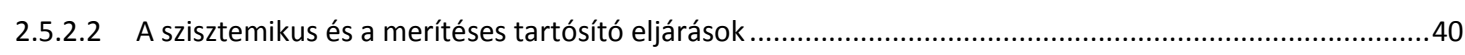

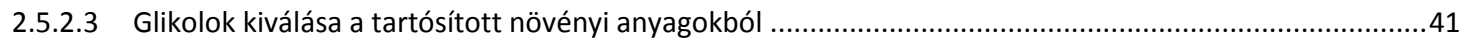

2.5.2.4 A tartósító oldat összetevői ...........................................................................................................

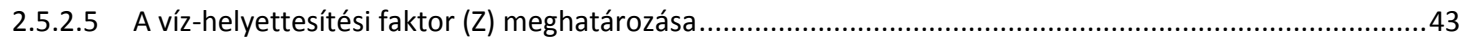

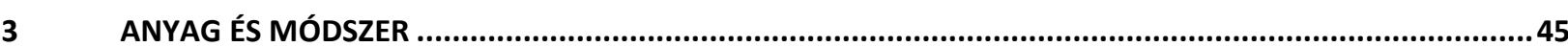

3.1 BARKÁS VESSZÖ TERMESZTÉS CÉUÁBÓL SZELEKTÁLT SALIX KLÓNOK MORFOLÓGIAI ÉS FENOLÓGIAI VIZSGÁLATA, VESSZŐHOZAMA ÉS GYÖKERESEDÉSE.

3.2 A MELEGTALP KEZELÉS, A GYÖKEREZTETŐ SZEREK, ÉS A SZAPORÍTÁSI IDŐPONTOK HATÁSÁNAK VIZSGÁLATA A GYÖKERESEDÉSRE

3.3 SALIX FAJOK KÁROSÍtÓ́INAK ÉS MÁS MINŐSÉGRONTÓ TÉNYEZŐINEK VIZSGÁLATA 
3.5 SALIX VESSZŐK HOSSZÚ TÁVÚ TARTÓSÍTÁSI LEHETŐSÉGEINEK VIZSGÁLATA ............................................................51

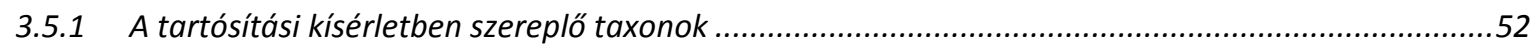

3.5.2 A tartósítási kísérlet során alkalmazott kezelések ................................................................52

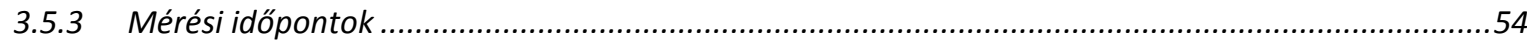

3.5.4 Új módszer Salix vesszők rugalmassági modulusának meghatározására........................................54

3.5.5 A vesszök víztartalmának és víz-helyettesítési faktorának (Z-érték) meghatározása.......................57

3.5.6 Morfológiai paraméterek értékelésének módszere ....................................................................58

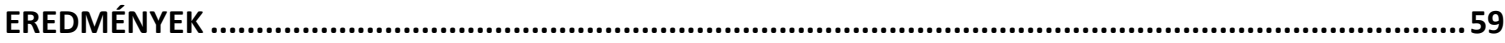

4.1 BARKÁS VESSZŐ TERMESZTÉS CÉLÁBÓL SZELEKTÁLT SALIX KLÓNOK MORFOLÓGIAI ÉS FENOLÓGIAI JELLEMZŐI, VESSZŐHOZAMA ÉS GYÖKERESEDÉSE

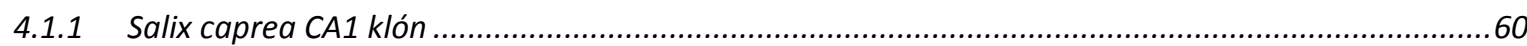

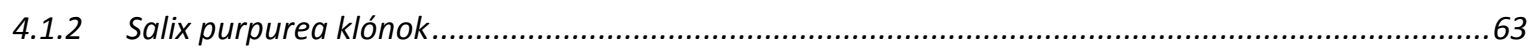

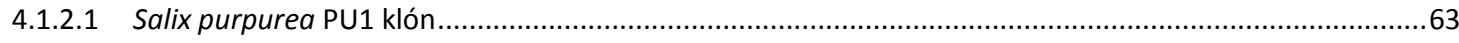

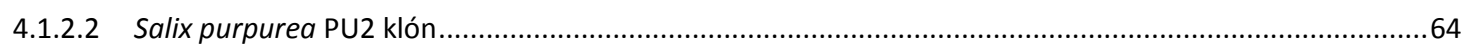

4.1.2.3 A rügypikkely leválásának sajátosságai .........................................................................................65

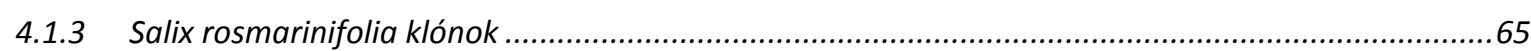

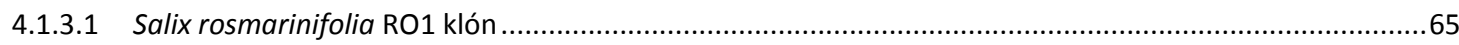

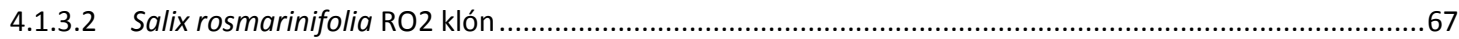

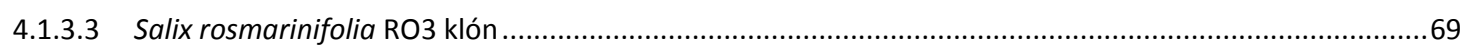

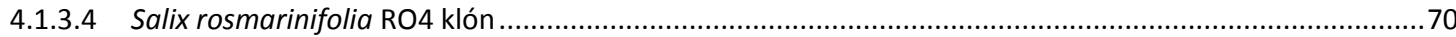

4.2 A MELEGTALP KEZELÉS, A GYÖKEREZTETŐ SZEREK ÉS A DUGVÁNYOZÁS IDŐPONTJÁNAK HATÁSA A GYÖKERESEDÉSRE ..........71

4.2.1 Salix caprea CA1 klón gyökereztetésének eredményei............................................................72

4.2.1.1 A melegtalp kezelés hatása a gyökeresedésre..................................................................................72

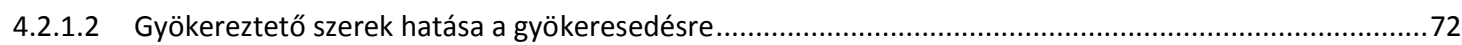

4.2.1.3 A dugványszedés és a gyökereztetés időpontjának hatása a gyökeresedésre ......................................73

4.2.2 Salix rosmarinifolia RO3 klón gyökereztetésének eredményei......................................................74

4.2.2.1 A melegtalp kezelés hatása a gyökeresedésre..................................................................................74

4.2.2.2 Gyökereztető szerek hatása a gyökeresedésre .................................................................................. 74

4.2.2.3 A dugványszedés és a gyökereztetés időpontjának hatása a gyökeresedésre ........................................75

4.3 SALIX FAJOK KÁROSÍTÓI ÉS MÁS MINŐSÉGRONTÓ TÉNYEZŐI ...........................................................................77

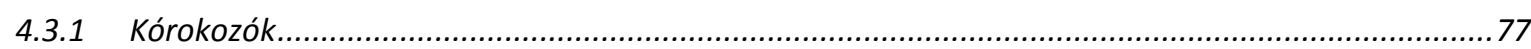

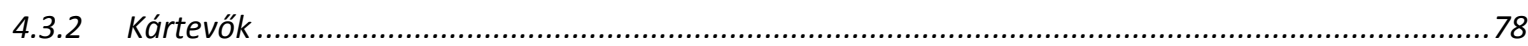

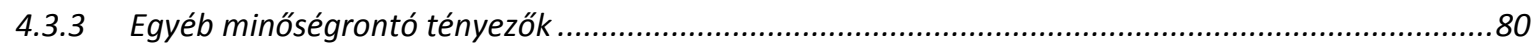

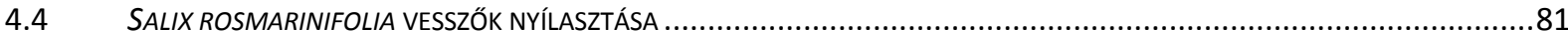

4.5 A TARTÓSÍTÓ KEZELÉSEK HATÁSA SALIX VESSZŐK RUGALMASSÁGÁRA ÉS MORFOLÓGIAI PARAMÉTEREIRE ........................85

4.5.1 Salix caprea vesszök tartósításának eredményei .....................................................................85

4.5.2 Salix purpurea vesszők tartósításának eredményei ................................................................90

4.5.3 Salix rosmarinifolia vesszők tartósításának eredményei..........................................................93

4.5.4 Salix vesszők víztartalmának és víz-helyettesítési faktorának (Z-érték) meghatározása..................97

4.6 ÚJ TUDOMÁNYOS EREDMÉNYEK 


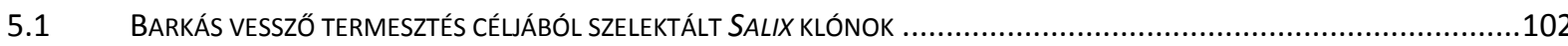

5.2 A MELEGTALP KEZELÉS, A GYÖKEREZTETŐ SZEREK ÉS A DUGVÁNYOZÁS IDŐPONTJÁNAK HATÁSA A GYÖKERESEDÉSRE .........104

5.2.1 Salix caprea CA1 klón gyökeresedése ...........................................................................105

5.2.2 Salix rosmarinifolia RO3 klón gyökeresedése ......................................................................106

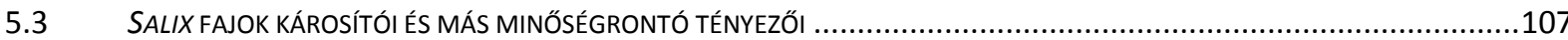

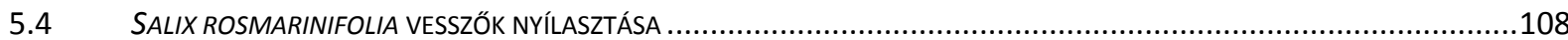

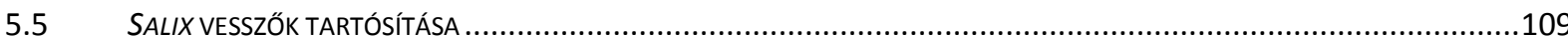

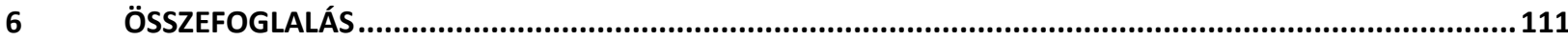

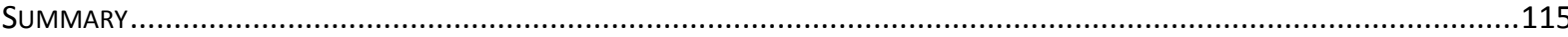

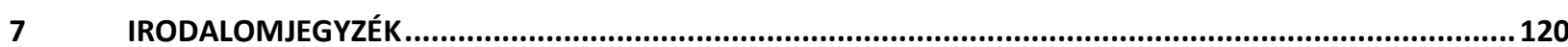

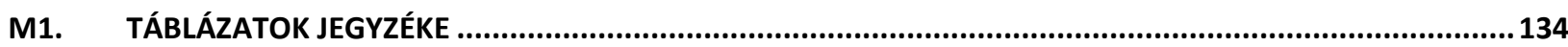

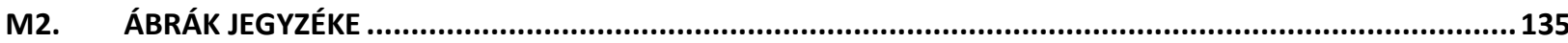

M3. FÚZ FAJOK NÉHÁNY EGYÉB FELHASZNÁLÁSI TERÜLETE .........................................................138

M4. FÜZ FAJTÁK NÉHÁNY JELLEGZETES TULAJDONSÁGA UPOV (2003) IRÁNYELVEK ALAPJÁN ....................139

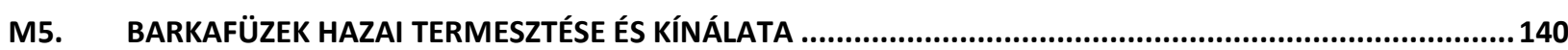

M6. GIBBERELLINSAV ALKALMAZÁSA EGYÉB DÍSZNÖVÉNYEK HAJTATÁSAKOR ........................................150

M7. GLIKOLOKKAL TARTÓSÍTHATÓ FÁS SZÁRÚ ZÁRVATERMŐK .......................................................152

M8. SALIX TAXONOK MIKROTECHNIKAI MÓDSZEREKKEL TÖRTÉNŐ VIZSGÁLATA ÉS ÁBRÁZOLÁSA .............153

M9. A GYÖKEREZTETŐ SZEREK, KEZELÉSEK, ÉS A DUGVÁNYOZÁS IDŐPONTJÁNAK HATÁSA A DUGVÁNYOK GYÖKERESEDÉSÉRE - JEGYZÖKÖNYV SZÖVEGES KIVONATA ...............................................................158

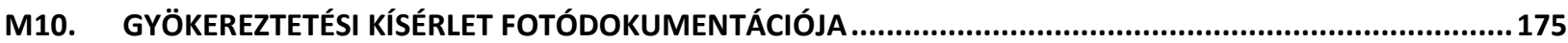

M11. GYÖKEREZTETÉSI KÍSÉRLET BONITÁLÁSI TÁBLÁZATAI ......................................................................182

M12. S. CAPREA KONTROLL DUGVÁNYOK GYÖKERESEDÉSE MELEGTALPON ÉS MELEGTALP NÉLKÜL ..............183

M13. KELPAK -KAL FÉL-, ILLETVE 8 ÓRÁN KERESZTÜL FELSZÍVATOTT S. CAPREA DUGVÁNYOK GYÖKERESEDÉSE MELEGTALPON ÉS MELEGTALP NÉLKÜL .184

M14. $6 \%$ NAFTIL-ECETSAVVAL ALKOHOLOS OLDAT ÉS POR FORMÁTUMBAN KEZELT S. CAPREA DUGVÁNYOK GYÖKERESEDÉSE MELEGTALPON 185

M15. S. ROSMARINIFOLIA KONTROLL DUGVÁNYOK GYÖKERESEDÉSE MELEGTALPON ÉS MELEGTALP NÉLKÜL

M16. KELPAK -KAL FÉL-, ILLETVE 8 ÓRÁN KERESZTÜL FELSZÍVATOTT S. ROSMARINIFOLIA DUGVÁNYOK GYÖKERESEDÉSE MELEGTALPON ÉS MELEGTALP NÉLKÜL 187

M17. $6 \%$ NAFTIL-ECETSAVVAL ALKOHOLOS OLDAT ÉS POR FORMÁTUMBAN KEZELT S. ROSMARINIFOLIA DUGVÁNYOK GYÖKERESEDÉSE MELEGTALPON ÉS MELEGTALP NÉLKÜL 188

M18. SALIX CAPREA ÉS S. ROSMARINIFOLIA VÍZTARTALMÁNAK ÉS Z-ÉRTÉKÉNEK MEGHATÁROZÁSA........... 189 KÖSZÖNETNYILVÁNYÍTÁS 


\section{BEVEZETÉS}

\subsection{A hazai barkafüzek, mint vágott virágok (barkás vesszők) alkalmazásának lehetőségei és problémái}

A dísznövények piacán a hagyományos (növényházi) vágott virágok mellett az elmúlt évtizedben mind népszerübbé váltak az úgynevezett fás szárú vágott virágok. Ezek föként szabadföldön termeszthető, fás szárú növények levágott hajtásai, vesszői vagy ágai, melyek díszítőértékét a rajtuk lévő bimbó, virág, termés, esetleg a különleges vesszőszín vagy -forma adja. Ezek az úgynevezett különleges, vagy fás szárú vágott virágok kiválóan felhasználhatók a legkülönbözőbb virágkötészeti alkotásokban. Lehetnek a csokrot kitöltő, lazító elemek, vagy akár annak fő díszei is. Megjelenésük, díszítőértékük megközelíti, esetenként felülmúlja a hagyományos vágott virágokét, termesztési költségük azonban jóval alacsonyabb. Ilyen például a különleges formájú Corylus avellana 'Contorta'; a fényes, színes vesszőjü Cornus alba 'Sibirica' (vörös) vagy Cornus stolonifera 'Flaviramea' (sárga); a bimbókkal díszítő Skimmia japonica 'Rubella'; a virágos Forsythia x intermedia 'Spectabilis és Lynwood' és Syringa fajták virágos hajtásai. Felhasználhatók a díszalma (Malus) fajok terméses ágai, vagy a fehér, illetve színes bogyós Symphoricarpos vesszők; a sokféle formájú és színárnyalatú csipkebogyós vesszők pl. Rosa 'Autumn's Pride'; vagy akár a paralécektől különleges Ulmus vesszők, gallyak, ágak.

A fás szárú vágott virágok népszerüsége már az ezredforduló tájékán fellendült, a jelenlegi válság idején, a dísznövények piacán is jelentkező gyengébb fizetőképesség miatt termesztésük jelentősége különösen megnőtt.

Ilyen különleges vágott virágok a Húsvétot megelőző időszakban keresett barkás füzveszszők is, melyek nem csak a Húsvéti dekoráció részei lehetnek, hanem - különösen nyugati országokban - már januártól megjelennek a tavaszt idéző virágcsokrokban és -kompozíciókban.

Magyarország viszonylag gazdag füz fajokban, az egyes fajok változékonysága pedig rendkívül sokféle alakot és színt eredményez. Hazánk 12 füzfajának számtalan alfaja, változata és hibridje olyan genetikai gazdagságot rejt, melyet érdemes alaposan feltárni és kiaknázni. Hazánk, különösen az Alföld jellegzetes szubkontinentális klímája és egykori hatalmas vízjárta területei kedvezőnek bizonyultak a füzek sokféle alakjának kialakulásához, és lehetővé teszik ezek termesztését is.

Hazánkban és a többi mérsékelt övi keresztény országban a barkás vesszők felhasználása elsősorban a Húsvét ünnepköréhez kötődik, mely minden évben más időpontra eső, úgynevezett mozgó ünnep. Amennyiben kései időpontra esik, friss barkás vesszők már nem biztosíthatók gyüjtésből. A tél végi, kora tavaszi időszakban még általában nem jelent problémát a megfelelő frissességü áru beszerzése, ám későbbi Húsvét esetén gondot okoz, hogy a kiszáradt, esetleg el- 
virágzott, vagy lepergett barkájú vesszők gyakorlatilag használhatatlanok a virágkötészetben. Gyakran a Húsvét előtti hetekben már nem kapható friss áru, csak a korábban megszedett, többékevésbé kiszáradt vesszőket kínálják eladásra. A természetben a tövek gyakran ekkor már teljes virágzásban vannak, a megnyúlt füzérvirágzatok könnyen letörnek, leesnek a vesszőkről, a virágzatból kinyúló porzószálakkal már nem piacképes az áru. Az időben megszedett barkás veszszők ideális tárolása, tartósítása még nem megoldott.

Nagyobb mennyiségben elsősorban a kecskefüz (Salix caprea L.), a rekettyefüz (S. cinerea L.), a csigolyafüz (S. purpurea L.), és a cinegefüz (S. rosmarinifolia L.) barkás vesszőit forgalmazzák a hazai piacon. Ez utóbbi talán a legnépszerübb, a másik háromtól, illetve azok hibridjeitől jelentősen eltérő méretének, alakjának és változatos színű vesszőinek köszönhetően. A cinegefüz vékony, filigrán, és apró, gömbölyü barkákkal sürün berakódott vesszőit gyöngybarka néven forgalmazzák. Az előzőeken túl abban is különbözik ez a faj a többitől, hogy azokhoz képest egy hónappal később, legkorábban áprilisban virágzik, ennek megfelelően a piacon is jóval később jelenik meg. Ezért, míg a többi faj esetében a még virágzás előtt begyüjtött vesszők megfelelő tárolása, tartósítása jelent kihívást a kertészek és virágkötők számára, a gyöngybarkánál ennek fordítottja igaz. Gyakran a virágzás, helyesebben a virágzati rügyek fejlődésének idő előtti indítása (hajtatása) a cél, mert a késői megjelenés a piacon az értékesítési szezon kedvezőtlen lerövidülését okozza. Nyílasztásával több gyüjtő próbálkozott eredménytelenül.

A barkás füzvesszők napjainkban még elsősorban gyüjtés útján kerülnek a hazai piacra, ami természetvédelmi vonatkozású problémákat is felvet. A gyüjtött vesszők ára viszonylag alacsony, ugyanakkor a minőség gyakran hagy maga után kívánnivalót. Az áru kiszerelésének sincsenek még általános szabályai. A nagyjából azonos méretű vesszőket kötegelik közel azonos mennyiségű szálat tartalmazó „csomókba”, csokrokba, illetve nagyobb kötegekbe, bálákba. Esetenként megkülönböztetnek „szálas”, azaz el nem ágazódó vesszőkből álló, illetve „,bokros”, azaz egy száron több elágazással rendelkező vesszőkből álló árut, de nem ritkán ezek is keverednek egy kötegen belül. Az ár legtöbbször a vesszők hosszával egyenes arányban nő, de a különleges vesszőszínű, vagy teljesen egységes, rendezett áru, és a nagyobb, valamilyen szempontból dekoratívabb barka mind jelentősen növelheti az áru értékét. A hazai barkafüz fajok néhány érdekesebb, különlegesebb taxonjának termesztésbe vonása mind kertészeti, mind természetvédelmi szempontból kívánatos.

A hazai füzek közül összesen három fajt nevez a szakirodalom barkafüznek, de ezeken túl más Salix fajok, illetve számtalan hibridjük is alkalmas barkás vessző termesztésére. Ilyen célú termesztés nem gyakorlat hazánkban, és semmilyen adat nem áll rendelkezésre a barkás vesszők hozamára vonatkozóan, illetve a termesztés egyéb vonatkozásaiban is sok kérdés merül fel. Ismertek füz fajokon előforduló károsítók, de arra nincsenek adatok, hogy a barkás vessző ter- 
mesztés céljából telepített növényeken vajon milyen kártételre lehet számítani, illetve ez hogyan befolyásolja a barkás vesszők minőségét vagy mennyiségét. A gyöngybarka termesztésbe vonása a többitől teljesen eltérő habitusa miatt még több kérdést vet fel. Köztudott, hogy a füz fajok jól gyökeresednek. Ez alól sajnos épp a legszebb barkájú $S$. caprea porzós klónjai, illetve több különlegesen dekoratív barkájú füz kivételt képez. Ezeknek az ígéretes taxonoknak a szaporítása bonyolultabb, mint a fásdugványról jól eredő füzeké. Érdemes a gyökeresedést elősegítő kezeléseket megtalálni, hogy ne a xenovegetatív szaporítás maradjon az egyetlen megoldás.

\subsection{Célkitüzések}

Munkám során célul tüztem ki a termesztésbe vonás lehetőségeinek vizsgálatát néhány fás szárú vágott virágként alkalmazható (barkás vesszőivel díszítő) füz faj esetében. Ezek a Salix caprea, a $S$. purpurea, és a még nem termesztett, a többi füz fajtól jelentősen eltérő habitusú Salix rosmarinifolia. Az ország különböző pontjairól származó különleges klónokat gyüjtöttem, majd az általam nevelt növényeken morfológiai és fenológiai megfigyeléseket végeztem a termesztéstechnológia megalapozásának céljából. A nehezen gyökeresedő klónokkal szaporítási kísérleteket kívántam végezni, hogy megtaláljam a megfelelő gyökereztető szert és formátumot, kezelési időtartamot, és hőmérsékletet, mellyel ezek eredményesebben szaporíthatók.

Célom volt egy nyílasztási kísérlet beállítása, ahol a cinegefüz barkák mélynyugalmát a gibberellinsav $\left(\mathrm{GA}_{3}\right)$ hormon segítségével próbáltam megtörni. Arra kerestem választ, hogy lehetséges-e feloldani a rügyek mélynyugalmát ezzel a növényi hormonnal, és így hajtatni azokat, valamint milyen koncentrációban és mennyi ideig szükséges, illetve elégséges alkalmazása.

A korai gyűjtésből és hosszas tárolásból adódó problémák megelőzésére célul tủztem ki egy megfelelő tartósítási eljárás kidolgozását, illetve azt is szerettem volna megvizsgálni, vajon egy ilyen kezelés mennyivel eredményez tartósabb barkás vesszőket, mint a hütött tárolás. Bizonyos fás szárú vágott virágok tartósítására sikeresen alkalmaznak glicerines tartósító oldatokat, de barkás Salix vesszők tartósításával kapcsolatban még nem végeztek kutatásokat. Előzetes kutatásaimban már kísérleteztem a glicerines tartósítással, de a kezelések kiértékelésére nem találtam megfelelő módszert. Ezért célom volt még egy objektív, számszerűsíthető adatokat szolgáltató módszer kidolgozása a glicerines tartósítás hatásának értékelésére. 


\section{IRODALMI ÁTTEKINTÉS}

\subsection{A Salix nemzetség bemutatása}

\subsubsection{A Salix nemzetség általános jellemzése és taxonómiája}

A Salix nemzetség a hagyományos taxonómia, EHRENDORFER (1991) rendszere szerint BORHIDI (1998) után a zárvatermők törzsén (Angiospermatophyta) belül a kétsziküek osztályába (Dicotyledonopsida), a dilléniaalkatúak alosztályba (Dilleniidae), és a füzvirágúak (Salicales) rendjébe tartozik. A rend egyetlen családjába (füzfafélék családja - Salicaceae) a Salix nemzetség mellett még két további nemzetség tartozik, a hazánkban ismert Populus (nyár), és a nálunk kevésbé ismert Chosenia [REHDER, 1951]. Korábban a rendet az úgynevezett barkásfákkal (Fagales rend) vélték közeli rokonoknak, ám fitokémiai tulajdonságai ezt cáfolják [BORHIDI, 1998]. A Salicales rendben hiányoznak a barkásokra jellemző anyagok (például ellágsavak és ellágtanninok), ugyanakkor jellemzőek rájuk az utóbbiakból nem ismert heterozidok, főleg a szalicin és populin, melyek gyulladásgátló és lázcsillapító hatása régóta ismert a népi gyógyászatban [TURCSÁNYI, 2000]. További adatok és érdekességek a Salix nemzetség humán gyógyászati és egyéb alkalmazásáról az M3. mellékletben (138. o.) találhatók.

A Salicaceae családba közel 500 [BORHIDI, 1998] (más forrás szerint 200 [TURCSÁNYI, 2000]) fa- és cserjefaj tartozik, többségük az északi mérsékelt övön (Európa, Kanada, Japán, Amerikai Egyesült Államok) terjedt el. Ugyanakkor TERPÓ (1986) szerint csak a Salix nemzetségbe mintegy 500 faj, GRIFFITHS (1997) szerint körülbelül 300 cserje és fa, FRANK (2008) szerint 350-400 faj tartozik, és közel 40 Populus faj ismert. KRÜSSMANN (1986) is közel 500 Salix fajt említ. Európa flórájában 2010-es és 2013-as keresésem eredményeképpen egyaránt 243 találatot kaptam a Salix nemzetségre a Royal Botanical Garden of Edinburgh által összeállított Flora Europaea adatbázisban [RBGE, 2013]. A pontos számot nehéz meghatározni, mert számos faj azonosnak bizonyult korábban leírt taxonokkal, esetleg azok alfajaként vagy változataként kerültek a szakkönyvekbe. A család evolúciós értelemben még kevéssé stabilizálódott, különösen a füz fajok elhatárolása nehéz a magas fokú hibridizáció miatt [PODANI, 2003].

A mérsékelt égövben a fás növények közül az evolúció során a Salix nemzetségben alakult ki a legtöbb különböző életforma a törpecserjéktől a nagy fákig. Az egyes fajok kialakulásában jelentős szerepet játszott a hibridizáció, a kromoszómaszám-módosulás, és a poliploidia is nagyon elterjedt. A Salix nemzetségben az alap kromoszómaszám n $=19$, az egyes fajok kromoszómaszámai: $2 \mathrm{n}=38,76,114,152$ vagy 190 . A rendkívül változatos füz nemzetségben a számos hibrid miatt is nehéz a faji szintü taxonok elhatárolása. A nemzetség 3 alnemzetségre és közel 30 szekcióra bontható [GENCSI és VANCSURA, 1992]. 
A fentiekben leírt rendszertani besoroláskor a rend és család jellemzését BORHIDI után adtam meg, aki EHRENDORFER (1991) rendszerét követi [BORHIDI, 1998]. Újabban azonban egy teljesen más szemléletü rendszertan is kialakulóban van, melynek hazai úttörője PODANI JÁNOS. Ez utóbbi rendszertanban a Salicales rend nem létezik, helyette a Salicaceae család a Malpighiales rendbe került, mely a családok számát tekintve a leggazdagabb rend, a füzfaféléken túl még 36 családot tartalmaz. Maga a Salicaceae család is jelentősen bővült, az általunk legjobban ismert Populus és Salix nemzetségeken túl még 53 (!), főleg trópusi génusz tartozik bele [PODANI, 2003]. A zárvatermő növények modern növényrendszertani osztályozása a londoni Linné Társaság (Linnean Society) által folyamatosan újított úgynevezett APG (Angiosperm Phylogeny Group, magyarul Zárvatermö Filogenetikus Csoport) rendszerekben történik. Ezt létrehozása után 2003-ban az APG II. rendszer, majd a 2009. októberében elfogadott APG III. rendszer követte, melyet a Botanical Journal of the Linnean Society nevü folyóiratban tettek közzé. Az összes szárazföldi növényt magában foglalja, és nem foglalkozik a rendnél magasabb taxonómiai szintekkel. A főbb csoportok az úgynevezett kládok, melyekből kladogramok rajzolhatók az összefüggések ábrázolására. A füzeket tartalmazó kladogram ábrázolása helyett rövidebben a következőképpen írom le a Salix génusz besorolását: Angiosperms / Eudicots (valódi kétsziküek) / Core Eudicots / Rosids / Eurosids / Fabids (= Eurosids I.) / Celastrales \& Oxalidales \& Malpighiales. Ez utóbbi három rend az úgynevezett COM klád (a rendek kezdőbetüiből), és a Salicaceae családot tartalmazó Malpighiales a rend szintje feletti COM klád tagja. Az új rendszerben ez a leggazdagabb rend a családok számát tekintve. Az APG I. rendszerben 36 családot soroltak alá, az APG II. rendszerben 36 családot, a legújabb, APG III-ban 35 család, és 16 ezer faj tartozik bele. A növények Malpighiales rendbe tartozását csak a molekuláris filogenetika eszközeivel lehet felismerni; ez a rend nem is szerepel egyetlen morfológián alapuló rendszertanban sem, mivel, mint rend, igen változatos taxon. Ide tartozik a Salicaceae családon túl például a Vitaceae, Passifloraceae, Linaceae, Euphorbiaceae, Hypericaceae, stb. Míg a Salicaceae családba EHRENDORFER rendszere szerint 3 nemzetség tartozott, az APG I. rendszerben 53; az APG II. rendszerben 55; az APG III. rendszerben 56 nemzetség alkotja [BORHIDI, 1998; PODANI, 2003; APG, 1998; APG, 2003; APG, 2009].

A Salix nemzetségre jellemző, hogy a levelek általában keskenyek, ép szélűek, levélnyelük viszonylag rövid, szórtan helyezkednek el, és gyakran pálhalevél is található mellettük [BORHIDI, 1998]. A pálha kicsi és lehulló vagy nagy és maradó [GENCSI és VANCSURA, 1992].

Rügyeik alapvetően kétfélék lehetnek; porzós vagy termős virágrügyek és levélrügyek (hajtásrügyek). Az utóbbiak kisebb méretűek, az egyes fajokra kevésbé jellemzőek, rügyhatározáskor ezért a virágrügyeket vesszük figyelembe [SCHMIDT, 1995]. 
A virágok jellemzően egyivarúak, kétlakiak (bár a hermafrodita virágok is előfordulnak a nemzetségben) és barkaszerü virágzatba tömörülnek. A porzós virágzatban számos, sürün elhelyezkedő virág található, a termős barkában ritkásabban helyezkedik el kevesebb virág [FRANK, 2008]. A virágok leveles vagy levéltelen generatív törpehajtásokon, az elöző évi vesszők középső rügyeiből fejlődnek tömött felálló, vagy laza bókoló füzérekben. A tömött, felálló füzérek lombfakadás előtt, a laza bókoló füzérek lombfakadás után nyílnak. A csupasz virágok tojásdad vagy lándzsás, ép szélü murvapikkelyek hónaljában képződnek [GENCSI és VANCSURA 1992]. A murvapikkelyek GENCSI és VANCSURA (1992) szerint az elvirágzás után is maradók, de a fehér füznél terméséréskor már nem találhatók meg az egyes virágok murvapikkelyei a füzéreken [FRANK, 2008]. A virágok redukáltak, a lepel helyén egy kúp alakú diszkusz, vagy kis nektárium található. A porzós virágokban a porzók száma többnyire kettő (esetleg három vagy öt is lehet), a női virágokban egyetlen termő található, amely két termőlevélből forrt össze $/ \mathrm{G}_{(2)} /$. A Salix fajok részben rovar-, részben szélmegporzásúak [TURCSÁNYI, 2000]. A termő felsőállású, a placentáció parietális. Az apró, szőrüstökös repítőkészülékkel ellátott magvak a toktermésben 46 hét alatt érnek be. Általában szél útján terjednek (anemochoria), vízközeli fajoknál gyakran a víz is jelentősen hozzájárul a magvak terjesztéséhez (hidrochoria). A magokban nincs endospermium és csak néhány napig csíraképesek. Csak kifejezetten nedves körülmények között és fényen csíráznak [TURCSÁNYI, 2000; BARTHA, 2007]. A porzós- és termős egyedek aránya 4:1 természetes populációkban [FRANK, 2008].

Jelenleg nem ismert olyan biokémiai teszt vagy molekuláris genetikai analízis, mellyel meg lehetne különböztetni a porzós és a termős egyedeket fiatal korban, a még nem virágzó példányoknál. Hasonlóképp még nem sikerült az eddig elvégzett molekuláris genetikai (izoenzim, RAPD, RFLP, AFLP) és többváltozós morfológiai vizsgálatokkal (főkomponens analízis) egyértelmüen elkülöníteni a hazánkban leggyakrabban előforduló három füz fajt (törékeny füz - $S$. fragilis, fehér füz - S. alba, berki füz - S. x rubens) [FRANK, 2008].

A fajok többsége a Föld északi felén él, a Salix nemzetség a Holarktikus Flórabirodalom egyik jellemző fás nemzetsége [GENCSI és VANCSURA, 1992]. A déli féltekén (főleg a tengerszint feletti magasabb területeken) is találunk néhány füz fajt, egyedül Új-Zélandon és Ausztráliában nem őshonosak [BAILEY, 1958].

A legtöbb füz faj jól türi a magas vízállást és a nehéz öntéstalajokat, ezért főleg folyók hullámterében alkotnak erdőket, cserjéseket, nem véletlenül kapták a „folyók fája” címet az erdészektől [FIRBÁs, 2004, szóbeli közlés]. Tipikus pionír fajok. Élőhelyükre a nemzetség latin neve is utal. A Salix szó ugyanis vélhetően a keltából eredeztethető, amely nyelvben a „sal” szó közelit, a „lis” szócska vizet jelent [JOHNSON és SMITH, 1979]. A nemzetség elnevezése egy másik magyarázat szerint a latin „salio, -ire” (magyarul: ugrani, fölhágni, növekedni) szóból ered, utal- 
va a fajok gyors növekedésére [BARTHA, 2008]. A fajok valóban igen gyors növekedésűek, hamar cserjévé vagy fává fejlődnek, és korán el is öregednek, hacsak nem ifjítjuk öket rendszeresen. Hazánkban a füzek területaránya az összes erdő területszázalékában 1970-ben 0,7\% volt [KERESZTESI, 1971].

A Salix fajok hasonló tulajdonságaik alapján szekciókba sorolhatók [KRÜSSMANN, 1986], a nemzetséget körülbelül 30 szekcióra bontották [GENCSI és VANCSURA, 1992]. Az egy szekcióba tartozó fajok egymással gyakrabban hibridizálódnak [NAGY, 2004, szóbeli közlés], de előfordul különböző szekciókba tartozó fajok kereszteződése is. A $S$. caprea és a $S$. cinerea a Capreae szekcióba, a $S$. rosmarinifolia az Incubaceae szekcióba, a $S$. purpurea a Purpureae szekcióba tartozik [KRÜSSMANN, 1986].

Egyszerübb rendszerek az Európában honos füzek három fó csoportját említik, ezek a fatermetü füzek, a kecskefüzek és a csigolyafüzek csoportja. A kecskefüzek csoportjára jellemző, hogy cserjék vagy ritkábban fatermetüek; általában kemény, ráncos levelüek, lombfakadás előtt jelennek meg barkáik, melyekben a fellevelek csúcsa fekete. Ebbe a csoportba tartozik a $S$. caprea és a S. cinerea. A csigolyafüzek rendszerint hosszú és hajlékony vesszőjű cserjék, hoszszú, keskeny levelekkel, általában lombfakadás előtt megjelenő barkákkal. Ide tartozik a $S$. viminalis és a $S$. purpurea [POLUNIN, 1981]. GENCSI és VANCSURA (1992) a füzek három alnemzetségét említi, ezek a fatermetü füzek (Salix), a bokorfüzek (Caprisalix), és a törpefüzek (Chamaetia), azaz a PoLUNIN (1981) csoportosítása szerinti kecskefüzek és csigolyafüzek csoport itt egybe került a bokorfüzek (Caprisalix) csoportban. A dolgozat témáját képző jelentős fajok a második alnemzetségbe, azaz a bokorfüzek csoportjába tartoznak, mely alnemzetségen belül viszonylag jól elhatárolódnak a ráncoslevelü füzek (Rugosae szekció). A Rugosae szekcióba tartozó füzek levelei elliptikusak vagy tojásdadok, nemezesen molyhosak, fonákjuk ráncos az erősen kiálló hálózatos erezettől. Virágaik vastag, tömött füzérekben nyílnak, melyekben a murvapikkelyek csúcsa fekete. Ebbe a szekcióba sorolják a kecskefüzet ( $S$. caprea), a rekettyefüzet (S. cinerea) és a füles füzet (S. aurita) [GENCSI és VANCSURA, 1992].

GRISVARD és CHAUDUN, francia szerzők négy csoportba osztva írják le a füzeket, melyek a

(1) Fatermetủ és kosárfonó füzek,

(2) Szomorúfüzek,

(3) Kecskefüz típusú fajok, és

(4) Magashegyi füz fajok.

Az első csoportba sorolják a $S$. purpurea és $S$. viminalis fajokat, a harmadikba tartozik a $S$. aurita, a $S$. caprea, a $S$. cinerea és a S. rosmarinifolia [GRISVARD, CHAUDUN, 1964]. 
BARTHA (2007) a következő gyakorlati csoportosítást ismertette dendrológia előadásában, mely csoportokban akár rendszertanilag különböző szintü taxonok (alnemzetség, sorozat, szekció) is keveredhetnek:

(1) Faalakú füzek

(2) Bokorfüzek (pl. S. purpurea, S. viminalis, S. rosmarinifolia)

(3) Ráncoslevelü füzek (pl. S. caprea, S. cinerea)

(4) Törpefüzek

\subsubsection{Hazánkban őshonos fontosabb barkás Salix fajok}

Az egyes fajok számtalan botanikai változatából, melyekből különösen Soó (1970) jegyez sokat, azokat emelem ki, melyek a barkás vessző szempontjából bírnak különleges, értékes tulajdonsággal (pl. sajátos vesszőszín vagy barkaméret). A számtalan különböző levélformájú, vagy a normálistól eltérő habitusú alakot nem sorolom fel. Szinte minden, lombfakadás előtt virágzó füznek létezik olyan változata, melynek virágzatai a lombfakadással egy időben, esetleg ősszel, a hajtások végén jelennek meg. Barkás vesszőként nem használhatók, ezért ezekre sem térek ki.

Itt szeretném megjegyezni, hogy a népnyelvben barkának nevezett szervek a füz vesszőjén botanikai értelemben nem a kifejlett virágzatok, hiszen még csak a virágzás előtti, a megnyúlási szakaszt megelőző állapotban vannak, melyekről többnyire már lehullott a rügypikkely. A jó árut képező „,barka” tehát csak egy viszonylag rövid ideig tartó stádium a növény életében, hiszen ha a füz kivirágzik, már nem értékesíthető, a korábbi állapotban pedig ugyanezt „,csak” rügynek nevezzük. Ráadásul a vizsgált füz fajoknak nem barkavirágzata van, hanem füzér. Ökonómbotanikai értelemben használhatjuk a barka kifejezést, botanikailag pontosan FELHŐSNÉ (1999) jegyzete és több dendrológiai munka [TÓTH, 2012; TURCSÁNYI, 2000; GENCSI és VANCSURA, 1992; BARTHA, 1999] alapján meggyőződésem, hogy ezek a botanikailag helyesen füzérvirágzatok. Mivel ez a köztudatban tévesen barkaként terjedt el, és a virágkötészeti árut is így nevezzük, ökonómbotanikailag elfogadható a barka terminológia is. Ezért amikor a füzfajok jellemzésénél, illetve más helyen is a dolgozatomban barkát írok, az a lombfakadás elött virágzó fajok feljebb leirt állapotban lévő virágzatára vonatkozik. Piacképes áru esetében tehát barkát említek, más esetben a virágzat jellemzésénél a füzér kifejezést használom.

\subsubsection{Salix caprea $\mathrm{L}$.}

Magyarul kecskefüz, nevezik leányfüznek és pálmafüznek [PRISZTER, 1998]. Szinonim nevei: S. caprea L. ssp. eucaprea L. HYL. 1945, S. hybrida VILL. 1789, S. praecox SALISB. 1796, S. tomentosa SER. 1815. [SOÓ, 1970]. 
Magas, 3-6 m-es cserje, gyakran 6-10 m magas kis fává is megnő. A vesszők kezdetben szürkés szőrzettel borítottak, később kopaszok és fényes pirosas-barnák lesznek, termős példányokon általában teljesen zöld színüek. Kérge sima, szürke, az idős fáké hosszirányban repedezett [KRÜSSMANN, 1986; TóTH, 2012]. A hozzá igen hasonló S. cinerea (rekettyefúz) fajtól megkülönböztető bélyege, hogy a gally két éves része már teljesen kopasz (a rekettyefüzé molyhos) [BARTHA, 1997]. A rügy tojásdad, hegyes, kopasz, a rügypikkely fénylő, zöldes- vagy vörösesbarna. A hajtás felső szakaszán álló virágrügyek igen nagyok, duzzadtak, csőrszerüen kifelé hajló csúccsal [GENCSI és VANCSURA, 1992]. Levele 3-5 cm széles, 5-10 cm hosszú, széles- vagy hosszúkás tojásdad, közepén a legszélesebb, lekerekített vállú, csúcsa hegyes [TóTH, 1969; То́тн, 2012]. A levélszél lehet ép, fürészes, vagy szabálytalanul csipkés, a levél színe rendszerint kopasz, ráncos fonáka lágy, tömötten szürkés molyhos, kiálló sárgás erezettel. A levéllemez színe fényes sötétzöld, a fonákon a molyhosság miatt szürkés. A levélnyél 1-2 cm-es. A barka majdnem vagy teljesen ülő, lombfakadás előtt jelenik meg. A tojás alakú porzós barkák felnyílás előtt sürün ezüstös-gyapjasak, virágzáskor akár 4,5 cm hosszúak aranysárga portokokkal, illatosak [KRÜSSMANN, 1986; TóTH, 1969; TÓTH, 2012]. A murvapikkelyek feketék, hosszú szőrüek [GENCSI és VANCSURA, 1992]. A termős barkák kezdetben a porzósoknál kisebb méretüek [RETKES, 2004, szóbeli közlés], végül 7 cm hosszúságot is elérhetnek. A kocsányon lévő magház szőrözött, palack alakú, a bibe ülö. Virágzási ideje március-április [KRÜSSMANN, 1986]. Diploid (2n: 38) vagy poliploid (2n: 57, 76) [SoÓ, 1970].

Egész Európában és Észak-kelet Ázsiában elterjedt a távoli északi vagy déli szélsőséges területek kivételével [KRÜSSMANN, 1986]. Hazánkban sokfelé megtalálható, elsősorban vágásokban, nedves erdőszéleken. A dombvidékeken és a középhegységeinkben gyakori, az Alföldön szórványosan fordul elő [GENCSI és VANCSURA, 1992; SIMON, 2000]. Jó alkalmazkodóképességü, szárazabb, meszes helyen is megél, mérsékelten árnyéktürő [TóTH, 1969]. A többi hazai füz fajunk előfordulásától eltérően a kecskefüz élőhelye nem kötődik szorosan a vízhez, illetve vízpartokhoz, jellemzően a lomblevelü fák erdőzónájának cserjefaja. Magyarországon általánosan elterjedt, de a nagyobb síkságoknak inkább csak a peremvidékein található meg [GENCSI, VANCSURA 1992]. Talaj iránt közömbös vagy inkább mészkerülő; üde vagy nyirkos, tápanyagban gazdag, nyers vagy gyengén savanyú-szelíd humuszos törmelék-, vályog-, homok-, és öntéstalajokon fordul elő, talajkötő [SoÓ, 1970]. Igazi pionír, zavarástürő faj, évszázadok óta ültetik [SIMON, 2000]. A porzós példányok különösen díszesek kora tavasszal nyíló barkáikkal. Vesszőiket ilyenkor levágva értékesítik [TÓTH, 1969]. Hazánkban az erdészek a múlt század elején gyomfának tekintették és irtották, de később „,védelmükbe vették” [MAJER, 1966].

Kapcsolódó fajok, alfajok, változatok, fajták, hibridek: 
S. caprea L. tricolor HORT. és S. caprea L. variegata HORT. néven leírt taxonok a reketytyefüz 'Tricolor' fajtájával egyeznek meg, melyet lejjebb jellemzek.

Salix dasyclados WIMM. Magyarul molyhoságú füz. MAJER (1966) erdészeti jegyzete szerint jól gyökeresedik, dugványozható, és szép hímivarú barkái vannak. A kecskefüz és kenderfüz hibridje (caprea $\times$ viminalis), hazánkban a természetben megtalálható [MAJER, 1966]. HILLIER (1974) szerint három faj hibridje (caprea $\times$ cinerea $\times$ viminalis $)$.

Salix x smithiana WILLD. Magyarul szépbarkájú füz. KRÜSSMANN (1986) és GENCSI és VANCSURA (1992) szerint $S$. caprea és $S$. viminalis, TótH (2012) szerint $S$. cinerea és $S$. viminalis hibridje. Erős növekedésü, nagyméretü (3-6 méteres) cserje vagy kis fa. Hosszú, vastag, merev, felfelé törő erős hajtásai fiatalon molyhosak, később lekopaszodnak, fényeszöldek. Radikális visszavágást követően újra erőteljes, barkákkal dúsan berakódó vesszőket hoz. TÓTH (2012) szerint a legjobb és legszebb barkafüz, 2,5-4 cm-es hosszú, tojásdad, majdnem ülő, hímivarú barkái lombfakadás előtt, márciusban nyílnak. A murvapikkelyek visszás-tojásdadok, csúcsukon feketék, selymesen szőrösek. Vadon csak a Brit szigeteken fordul elő. [HILLIER, 1974; NAGY és SCHMIDT, 1991; TóTH, 2012]. A hibrid 259/64 jelü klónját a napos oldalon közepesen zöld vesszőszín jellemzi [UPOV, 2003].

var. caprea L. f. flava HARTIG 1852 (aurigera SCHUR 1866). Az ágak, a hajtások, a rügyek és a levélnyelek aranysárgák [SoÓ, 1970].

var. caprea L. f. microstachya TOEPFFER 1915. A barkák rövidek, tompák.

var. caprea L. f. macrostachya TOEPFFE 1915. A barkák nagyok, hosszúak.

var. caprea L. f. laxiflora ANDERSS. 1867. A barkák laza virágúak [SoÓ, 1970].

'Kilmarnock' - KRÜSSMANN (1986) szerint a 'Pendula' fajta termős megfelelöje, angol nemesítés. DIRR (1998) is termős fajtának említi. TóTH (2012) szerint hímivarú. A gyakorlatban Európában porzós példányokat értékesítenek 'Kilmarnock' néven. Napjainkban Európában a 'Pendula' helyét kezdi átvenni, mert lombfakadás előtt megjelenő barkái annál jóval dekoratívabbak; nagyobbak, és színük ezüstös. DIRR (1998) szerint a két fajta ('Pendula' és 'Kilmarnock') azonos. HiLliER (1974) is a 'Pendula' fajtával azonosként írja le. Angol neve „Kilmarnock Fűz”, és szintén termős példányként ismerik 1844 óta. Az ENA (European Nurserystock Association, Európai Faiskolások Egyesülete) évkönyve alapján 'Kilmarnock' az elfogadott neve a porzós pendula formának [HoFFMANN, 2000; HOFFMANN, 2005].

'Mas' - Régebben az alapfaj porzós példányait forgalmazták ilyen néven. Ma már ezt nem tartják önálló fajtának, alig találkozni ilyen névvel. Helyette különösen gazdagon virágzó, nagy barkájú, hímivarú taxonokat forgalmaznak, pl. 'Atlas'.

'Silverglow' - Gyakrabban németül 'Silberglanz' néven forgalmazott, valóban ezüstösen csillogó, nagybarkájú fajta. Vesszője fényes sötétbarna, majdnem fekete színű, jó kontrasztot ad 
a rajta lévő ezüstös-fehér barkákkal. Gyakran többtörzsü, 4-6 m-es kis fa vagy magas cserje. A legtöbb talajtípuson termeszthető, télállósága kitűnő. Gyors növekedésü, a vesszők beérése az időjárástól függ, általában január és február hónapokban szedhető. Gyakran már novemberdecemberben lehull a virágzati rügyek fedőpikkelye, a sötét vesszőkön a nagy barkák a márciusi virágzás végéig láthatók. Európában ez a virágkötészetben leginkább keresett fajta [KOLSTER, 2003; RETKES, 2004, szóbeli közlés; TÓTH, 2012].

'Weeping Sally', korábban 'Pendula' - Az utóbbi néven egy porzós és egy termős klónt forgalmaztak szabadföldi dísznövényként. Az Amerikai Egyesült Államokban föleg a termős klónt termesztik, melyet Roy LANCESTER 'Weeping Sally'-nek nevezett el. Az eredeti klónt az Ayr folyó partján 1853 előtt találta a skót Kilmarnocki THOMAS LANG [DIRR, 1998]. Gyengébb növekedésü, az ágak merevebbek, növekedésük csüngő, kisebb boltívet formáznak, sürü elágazásokkal. Már 1853 előtt ültették, barkái nem feltűnően díszesek [KRÜSSMANN, 1986]. A termős 'Pendula' jelenleg hivatalos neve 'Weeping Sally', a porzósé 'Kilmarnock' [HoffmanN, 2000; HOFFMANN, 2005]. Ritkábban szaporítják, mint porzós párját [TóTH, 2012].

\subsubsection{Salix purpurea $\mathrm{L}$.}

Magyar neve csigolyafüz. Ismert még bíbor(kérgü) füz és sárfüz néven [PRISZTER, 1998]. Szinonim elnevezések: S. monandra ARD. 1766, S. pratensis SCOP. 1772, S. oppositifolia KIT. 1863, S. condensata KIT. in JÁv. 1936. [SoÓ, 1970].

Vékony, egyenes, de hajlékony vesszőjü, közepes méretü cserje vagy kis fa, általában nem nő három méternél magasabbra. Vesszői kopaszak és fényesek, a rajtuk levő rügyek hengeresen kúposak, csúcsuk szárhoz simuló. A rügyek, illetve levelek gyakran eltoltan keresztben átellenesen, a hajtások felső részén látszólag átellenesen állnak [BARTHA, 1997; KRÜSSMANN, 1986]. Levele 3-12 cm hosszú, és legfeljebb $1 \mathrm{~cm}$ széles (kivéve a $S$. purpurea var. lambertiana-t, melynek szélesebbek a levelei). A levél alakja keskeny fordított-tojásdad vagy visszás-lándzsás, hegyes vagy kihegyezett csúcsú, széle igen finoman fürészes, főleg a csúcs felé. A levelek is kopaszok, színük mélyzöld, a fonákon halványabb vagy kékes-zöld. Pálhalevele nincs. A barka ülö, alakja keskeny, megnyúlt, 1,5-3 cm hosszú, általában kicsit görbült. Két porzója van, de a porzószálak teljesen összenőttek. Ez utóbbi tulajdonsága igen megkönnyíti a faj meghatározását, fontos határozóbélyege. A portokok kezdetben vöröses színủek, később feketék lesznek. A magház ovális, szőrözött. Márciustól májusig virágzik [SIMON, 2000]. Diploid (2n: 38) [Soó, 1970].

Európában egészen Észak-Afrikáig megtalálható [KRÜSSMANN, 1986]. Folyók, különösen a Duna, és patakok mentén a bokorfüzes (Salicetum purpureae) egyik fő alkotója, az egész Duna-völgyben elterjedt [SIMON, 2000; SoÓ, 1970]. Inkább mészkedvelő; nedves vagy időnként 
vízzel borított, tápanyagban gazdag, nyers vagy humuszos hordalék-, kavics-, öntés-, és homoktalajokon fordul elö, talajkötő pionír [SoÓ, 1970].

Nagyon régóta termesztett, sokoldalúan felhasznált faj, kosárfonáshoz gyakran ültetik. Az irodalom nem sorolja a barkafüzek közé, egy helyen találtam utalást dekoratív barkáira, melyek rendkívül dekoratív megjelenésüket a füzérekben található fekete murvapikkelyeknek, ezüstös szőröknek, majd a később a pirosló portokoknak köszönhetik [POLUNIN, 1981].

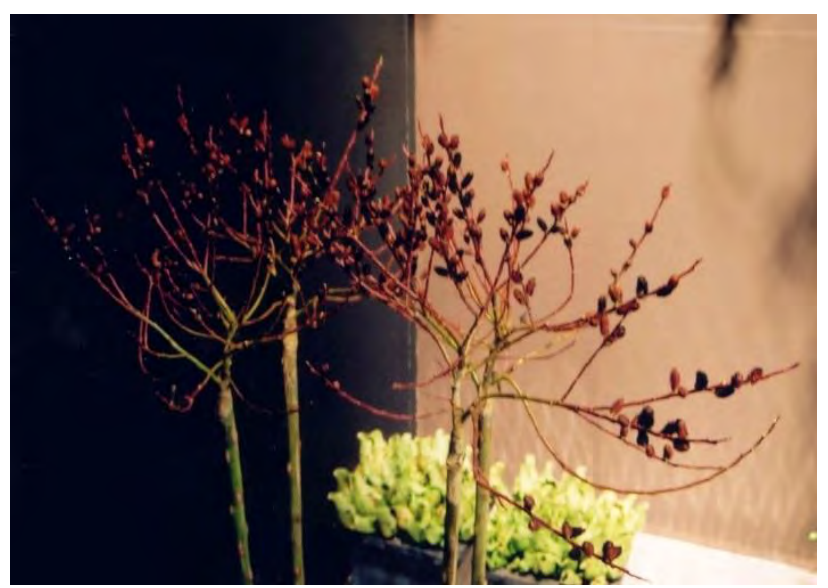

1. ábra: Magas törzsre oltott S. integra 'Kuroyanagi' az esseni IPM kiállításon (fotó: Treer, 2004)

Kapcsolódó fajok, alfajok, változatok, fajták, hibridek:

Salix integra THUNB. néven írtak le egy ehhez hasonló fajt, mely Japánban és Koreában él (S. purpurea L. auct. jap. non L.) [KRÜSSMANN, 1986]. Ugyanakkor HILLIER (1974) szerint ez a S. purpurea multinervis, illetve 'Axukime' fajtanéven is említi. Sok japán nemesítésű fajtája van, melyek Európában is igen népszerüek. Különleges barkás fajta a $S$. integra 'Kuroyanagi' (1. ábra). Érdekessége, hogy a barkák a rügypikkely alól előbújva kezdetben fekete színűek, később pirosra változnak. Ez a murvapikkelyek színének változása miatt van. Egy vesszőn rendszerint nem azonos időben fejlödnek a barkák, így egyszerre látható rajta piros és fekete is, amitől nagyon különleges látványt nyújt. Ez a fajta jól gyökeresedik, hátránya azonban, hogy a vesszők általában hiányosan rakódnak be barkával [RETKES, 2004, szóbeli közlés]. Hazánkban is ismert fehér-tarka levelü fajtája a 'Hakuro-Nishiki'. A fiatal levelek rózsaszínnel futtatottak, 'Albomaculata' néven is árulják. A japán 'Fuiri-koriyanagi' nevet is alkalmazzák rá, melynek jelentése „tarka kosárfonó füz” [BEAN, 1988] A 'Kuroyanagi' fajtával valószínűleg azonos a Salix 'Rubykins' [DIRR, 1998]. Ugyanakkor ez utóbbi fajtát egy amerikai katalógus a S. koriyanagi fajhoz tartozónak tünteti fel [HOMESTEAD, 2004]. HiLliER (1974) a S. koriyanagi KIMURA fajt $S$. purpurea japonica néven is említi (auctor megnevezése nélkül), melyet Japánban széleskörüen használnak kosárfonásra és bútorok készítésére. Ugyanakkor a S. japonica THUNB. fajnál már azt írja, hogy barkái a levelek fakadásával egy időben jelennek meg. 
Salix x cordata (amerikai füz). A csigolyafüz mandulalevelü füzzel (S. triandra L.) képződött természetes hibridje [CSAPODY et al., 1993]. Ugyanezt Soó (1970) S. leiophylla CAMUS 1905, nm. supertriandra TOEPFFER 1913, és S. americana hort. neveken jegyzi.

subsp. amplexicaulis (BORY \& CHAUB.) SCHNEID. Hasonló a subsp. lambertiana-hoz, de levelei föleg, vagy teljesen átellenesen állnak, gyakran valamivel kisebbek, ülők vagy közel ülők, a levélalap lehet félig szárölelő. A Balkánon és Kis-Ázsiában honos [KRÜSSMANN, 1986].

subsp. lambertiana (SM.) A. NEUMANN ex RECH. Vastagabb ágú alfaj; a levelek csak részben állnak átellenesen. A levél alakja fordított tojásdad vagy hosszúkás, a hosszú hajtásokon hossza a szélesség 4-8-szorosa, széle szinte teljesen fürészes. A faj elterjedési területén szinte mindenütt elöfordul, így hazánkban is, különösen síkságokon [KRÜSSMANN, 1986]. Változatként ugyanezt a taxont var. latifolia KERN. néven is leírták.

var. japonica, hivatalos nevén $\boldsymbol{S}$. koriyanagi KIMURA. Nagy, feltörő cserje, vagy kis fa, hajtásai barnák vagy sárgásbarnák, igen vékonyak. A levelek szórtan, vagy részben átellenesen helyezkednek el a hajtásokon, hosszúkás lándzsásak, hosszuk 6-8 cm, szélességük 5-10 mm. A levélalap lekerekített, a levélszél ritkásan fürészes, az egész levél vékony bőrszerü. A levél színe sötétzöld, fonáka kékeszöld. A barka megnyúlt, karcsú, a portokok sötét bordó színủek, a magház ülő, fehér szőrökkel dúsan borított, a bibe nagyon rövid. Koreából származik, Japánban sokfelé termesztik kötészeti célra [KRÜSSMANN, 1986].

var. purpurea L. f. purpurea L. A porzószálak csúcsukig összenőttek, tövükön szőrösek, a vesszők vöröslők, a levelek alul kékeszöldek.

var. purpurea L. f. Woolgariana BORRER ex HOOKER 1830. A vesszők sárgás-szürkék, a levelek alul kékes-szürkék.

var. purpurea L. f. ramulosa BORRER. A vesszők halvány sárgák, a levelek hosszúkáslándzsásak, alul halványabbak.

var. purpurea L. f. eburnea BORZI 1885. A vesszők elefántcsontszínűek.

var. purpurea L. f. pruinosa SCHATZ 1889. A vesszők hamvas-szürkék.

var. purpurea L. f. gracilis PETERM. 1846. A barka hosszú, vékony.

var. purpurea L. f. breviiulis TOEPFFER 1907. A barka $1 \mathrm{~cm}$ hosszú és széles.

var. purpurea L. f. conspicua A. MAYER 1909. A barka 40 x 5-7 mm nagy, murvái majdnem akkorák, mint a magház [SoÓ, 1970].

var. sericea (SER.) K. KOCH. A fiatal hajtások és a levélfonák selymesen szőrözött, később kopaszodó [KRÜSSMANN, 1986].

'Nana' (régebben 'Gracilis') - Törpe forma, 1-2 m magas, filigrán ágrendszerü és keskeny levelü; termős fajta, 1900 körül nemesítették. Németországban hozták forgalomba, az Urálhegységből származik. KRÜSSMANN (1986) alapján kosárfonásra kiváló, az általunk e néven is- 
mert fajta vesszöi azonban túl rövidek lennének e célra [SCHMIDT, 2004, szóbeli közlés]. TóTH (2012) szerint vékony vesszői finom fonottáru készítésére alkalmasak. Alacsony sövénynek is ültetik. Szinonim: var. nana DIECK; var. uralensis SPATH [KRÜSSMANN, 1986; TÓTH, 2012].

'Pendula' - Nagyon vékony ágú, termős fajta. Bokorként elfekvő hajtású, törzsre oltva csüngő ágú kis fának nevelhető. Svájcból származik, 1830 körül keletkezett. Szinonim nevei: $\boldsymbol{S}$. purpurea L. scharfenbergensis BOLLE; S. americana pendula DE VOS [KRÜSSMANN, 1986].

'Ripa' - Németországban 1980-ban nemesített fajta vékony, kopasz, sötétbarna hajtásokkal. Erős növekedésü, 1,5 m magas, terjedő töve talaj megkötésére (rézsük, vízpartok) alkalmas.

\subsubsection{Salix rosmarinifolia L.}

A S. rosmarinifolia magyarul cinege- vagy serevényfüz, rozmarinfüz és gyöngybarka néven is ismert [PRISZTER, 1998]. Népies nevei a nyúlvessző, és a kúszóvessző [KISS, 1944]. SoÓ (1970) és SIMON (2000) szerint a $S$. repens alfaja (S. repens subsp. rosmarinifolia L.), KRÜSSMANN (1986) változatnak tekinti (S. repens var. rosmarinifolia (L.) WIMM. \& GRAB.; S. repens var. angustifolia NEILR). A LINNÉ által leírt S. rosmarinifolia tekintetében is megoszlanak a vélemények. ANDERSSON szerint a $S$. repens keskenylevelü és gömbölyü barkájú formája. WIMMER úgy vélte, ez a $S$. repens és $S$. viminalis fajok hibridje ( $S$. viminalis-repens, LASCH, $S$. Friesiana, AND.) [WHITE, 1891]. A legújabb hazai összefoglaló flóramüben önálló fajként szerepel [KIRÁLY, 2009]. Szinonim neve: S. friesiana ANDERSS. [SimOn, 2000]. Az Amerikai Egyesült Államokban és Angliában S. rosmarinifolia néven a S. elaeagnos fajt, illetve annak keskenylevelü fajtáját, a S. e. 'Angustifolia'-t forgalmazzák [DIRR, 1999; HILLIER, 1974], ez azonban a valódi cinegefüztől teljesen különböző faj [BEAN, 1981].

Sürü növésü, rövid, elfekvő, kúszó, legyökerező szárú, és felálló, hajlékony hajtású, 50100 cm-es cserje. Vékony hajtásai fiatalon sárgásbarnák, selymesszőrösek, később sötétebb szürkésvörösek, a csúcsi rész kivételével kopaszok. A vessző vékony, selyemszőrzettel borított. A kicsi, hosszúkás rügyek 1-2 mm (2,5-4 mm KIRÁLY, 2009) hosszúak, vörösesbarnák, selymes szőrüek, szárhoz simulók, csúcsuk ellaposodó. A levél rövid és vékony, szálas-hosszúkás vagy hosszúkás-lándzsás, két vége elkeskenyedő; többé-kevésbé felálló, párhuzamos az ággal. A levélszél ép, a kifejlett levelek színe többé-kevésbé kopasz, a fonák rányomott ezüstös selymes szőrzetü. A levél SCHMIDT és NAGY (1991) szerint 1-5 cm, BARTHA (1999), GENCSI és VANCSURA (1992) és KIRÁLY (2009) szerint 1-3 cm; TóTH (2012) szerint 1-4 cm hosszú, 2-8 mm széles, 10-12 érpárral rendelkezik. Pálhaleve apró [BEAN, 1981] vagy hiányzik. Az apró barkák gömb alakúak, a murvapikkely szőrös, a porzószálak kopaszok, a toktermés szőrös. Április-májusban virágzik [KISS, 1944; BARTHA, 1999; BEAN, 1981; GENCSI és VANCSURA, 1992]. Diploid (2n: 38) [SoÓ, 1970]. 
Lápréteken, üdébb homoki gyepeken növő kis cserje. A természetes állapotokra utaló fajok csoportjában kísérő fajnak számít [SIMON, 2000]. Szeged környékén a kereszteződések folytán keverékfajok keletkeztek, KISS (1944) például összesen nyolcféle alakját találta meg és írta le, melyek többnyire a $S$. repens felé hajlanak (1. táblázat). Az alakok közti különbség a barka színében, a virágzás idejében, a levelek számában és alakjában, vagy a vesszők színében és fejlődésében nyilvánul meg.

\section{1. táblázat: Szeged környéki cinegefüzek alakjai (KISS, 1944)}

\begin{tabular}{|c|c|c|c|c|}
\hline $\begin{array}{l}\text { Alak } \\
\text { szám- } \\
\text { jele }\end{array}$ & Levél & Vessző & Barka & Egyéb \\
\hline I. & $\begin{array}{c}\text { 5-15mm h, 2-4mm sz, lassan hegyezett, egye- } \\
\text { nes nyelü, fonáka fehér selymes, színe elég } \\
\text { szőrös v. kopasz }\end{array}$ & vörös & $\begin{array}{l}\text { hímbarka cit- } \\
\text { romsárga }\end{array}$ & $\begin{array}{l}\text { S. rosmarinifolia } \\
\text { L.-alak }\end{array}$ \\
\hline II. & $\begin{array}{l}\text { 5-10mm h, 2-10mm sz, hirtelen hegyesedö, } \\
\text { fonáka fehér selymes, színe kissé szőrös }\end{array}$ & $\begin{array}{l}\text { alul sárgászöldes, } \\
\text { felül világospiros }\end{array}$ & & inkább $S$. repens \\
\hline III. & $\begin{array}{c}\text { 5-20mm h, 3-8mm sz, csúcsa tompás végböl } \\
\text { hegyes, fonáka sürün selymes, színe fiatalon } \\
\text { sürün selymes }\end{array}$ & sárgászöld & $\begin{array}{l}\text { hímbarka } \\
\text { narancspiros }\end{array}$ & $\begin{array}{l}\text { S. rosmarinifolia } L . \\
\text { var. argyrotricha } \\
\text { Borbás }\end{array}$ \\
\hline IV. & $\begin{array}{l}\text { 6-16mm h, 3-6mm sz, hirtelen hegyesedö, } \\
\text { fonáka selymes, színe gyéren szörös }\end{array}$ & $\begin{array}{l}\text { alul sárgás rózsa- } \\
\text { színü, felül pirosas }\end{array}$ & hímbarka sárga & S. repens-hez hajló \\
\hline V. & $\begin{array}{l}\text { 5-30mm h, 2-6mm sz, lassan kihegyezett, } \\
\text { fonáka selymes, színe kopasz }\end{array}$ & alul-felül pirosas & nővirágú & S. repens alak \\
\hline VI. & $\begin{array}{l}\text { 5-20mm h, 3-8mm sz, hegyes, fonáka gyéren } \\
\text { selymes, színe kopasz }\end{array}$ & egészen sárga & $\begin{array}{l}\text { hímbarka na- } \\
\text { rancssárga }\end{array}$ & $\begin{array}{l}\text { A szára világossár- } \\
\text { gás, valószínüleg } S \text {. } \\
\text { repens felé hajló } \\
\text { alak }\end{array}$ \\
\hline VII. & $\begin{array}{l}\text { 6-30mm h, 4-8mm sz, tompa végböl hegyes, } \\
\text { fonáka gyéren selymes, színe kopasz }\end{array}$ & $\begin{array}{l}\text { sárgásbarna, felül } \\
\text { barnapiros }\end{array}$ & $\begin{array}{l}\text { hímbarka na- } \\
\text { rancsvörös }\end{array}$ & $\begin{array}{l}\text { S. repens felé hajló } \\
\text { alak }\end{array}$ \\
\hline VIII. & $\begin{array}{l}\text { 4-30mm h, 3-6mm sz, kihegyezett, fonáka } \\
\text { selymes, színe kopasz }\end{array}$ & $\begin{array}{l}\text { sárgászöld, felül } \\
\text { pirosas sárga }\end{array}$ & $\begin{array}{l}\text { hímbarka kár- } \\
\text { minpiros }\end{array}$ & $\begin{array}{l}\text { S. rosmarinifolia } \\
\text { L.-alak }\end{array}$ \\
\hline
\end{tabular}

Közép- és Kelet-Európában él, nyugat felé Észak-Olaszországig és Belgiumig, északon Svédországig található meg [KRÜSSMANN, 1986]. A ssp. rosmarinifolia kontinentális alfaj, amely nyugatra DK-Svédországig, Közép- és D-Németországig terjed, Magyarországon kizárólagos, tőlünk keletre rokon kisfajok élnek [SoÓ, 1970].

KISS FERENC, aki tevékenysége folytán Móra Ferenc barátjától és erdésztársaitól a „szegedi erdők atyja” nevet kapta, utolsó cikke erről a fajról jelent meg az Erdészeti Lapok 1944. júliusi számában. A világháború legkegyetlenebb, legvéresebb napjaiban így írt: „Azért foglalkoztam ilyen részletesen a serevényfüz életével, mert öscserjéje a homoknak. [...] Több, mint fél évszázadon át sok kedves emlékem füzödik hozzá. Sokat kellett vele foglalkoznom, míg egyik-másik tulajdonságát ellestem. Kora tavasszal viritó kénsárga, vagy vöröses-narancssárga színü hímbarkái és a növirág kárminvörös bibéi sok kedves napot szereztek tavaszi napfényben az erdö csendjében. Mivel nehéz megtelepülése miatt a belterjes erdökultúra folytán mindig egyre kisebb térre szorul, ezzel a tanulmánnyal akarok elbúcsúzni töle. Ki tudja, lesz-e még valamelyik szaktársam- 
nak alkalma vele foglalkozni, és szereti-e még valaki olyan nagyon, mint én." [KISS, 1944]. Az elmúlt tíz évben folytatott kutatásaim során magam is ezt a fajt kedveltem meg leginkább.

CSAPODY (1982) és FARKAS (1999) nem említik védett növényeink között, SCHMIDT és То́тн (2003) szerint jelenleg védett növény, gyüjtése tilos. Az illetékes minisztériumból a hazai botanikusok levelezőlistájára küldött legfrissebb összeállítás szerint, továbbá a Magyar Állami Természetvédelem (2013) hivatalos honlapján feltüntetett lista alapján sem védett. Ugyanakkor gyüjtése miatt, és KISS (1944) megjegyzése alapján védendőnek nevezhető.

A szakirodalomban található leírások alapján meglehetősen zavaros képet kapunk a taxon faji hovatartozását illetően, igaz, a faj fogalmának meghatározása sokat vitatott kérdés [KÁRPÁTI és TERPÓ, 1968]. A hazánkban előforduló alakokat a magyar szakirodalomban több botanikus és kertész szakember (KIRÁLY, 2009; TÓTH, 2012; NAGY, 2013 szóbeli közlés, SCHMIDT, 2003; GENCSI és VANCSURA, 1992) említi önálló fajként, én is ezt a terminológiát követem, és önálló fajnak tekintem. Államilag elismert fajtája nincs.

\subsubsection{Magyarországon honos, barkás vessző termesztésre alkalmas egyéb füz fajok}

\section{Salix cinerea L.}

Hamvas füz vagy rekettyefüz [PRISZTER, 1998]. Szinonim neve a S. acuminata MiLl. 1768.: 76) [SoÓ, 1970]. Ezt a fajt $S$. caprea és $S$. viminalis keresztezésével HERIBERT NiLSON kutatónak sikerült reszintetizálnia [BORHIDI, 1998].

Feltörö habitusú, 3-5 vagy 4-7 m magas bokor. Viszonylag vastag, egyenes hajtásai vannak, a rügyekkel együtt maradandó, szürkés molyhosak. A gally két éves része is szörös, valamint az egész vessző vastag, molyhos szőrzettel borított. A tojásdad, duzzadt, szártól kismértékben elálló rügy csúcsa tompa, a rügy molyhos. Levele 5-11 cm hosszú, 2-3 cm széles, felső harmadában a legszélesebb, lándzsás vagy fordított lándzsás, hegyes vagy kerekített csúcsú, a levélváll gyakran ék alakú. A levélszél gyakran hullámos, távoli csipkés-fogas vagy majdnem ép. A levél színe szürkés pelyhes, fonákán molyhos, a levélnyél 10-15 mm hosszú. Március-áprilisban virágzik [SIMON, 2000; BARTHA, 1999; TóTH, 2012]. Egész Európában, Nyugat-Ázsiáig megtalálható nedves élöhelyeken. Mocsarak, lápok vizes szegélyén alkot társulást, a „gömbös bokorcsoportú” füzláp alkotója [SIMON, 2000]. Több határozókönyv is védendőnek nevezi ezt a fajt.

Kapcsolódó fajok, alfajok, változatok, fajták:

Salix x multinervis DöLl. Ez valószínüleg a természetben legelterjedtebb hibrid, a reketytyefüz és a füles füz (S. aurita L.) kereszteződéséből származik [SIMON, 2000]. Ugyanakkor KRÜSSMANN (1986) ezt a fajt (nem, mint hibridet), a S. integra (vagy S. purpurea) fajjal megegyezőnek tünteti fel, szinonimként.

m. ternata DUM. 1827. Egy rügyből 2-3 barka fakad [SoÓ, 1970]. 
'Böschungsteppich' - Német eredetü, 80-100 cm magas, elfekvő, legyökeresedő szárú fajta. Jó vízellátású területen kiváló talajtakaró, talaj- és rézsűmegkötésre alkalmas [TóTH, 2012].

'Tricolor' - Lassú növekedésü, az alapfajnál kisebb levelei zöld alapon fehér vagy fehérpiros foltosak, márványozottak. Termős, Németországból származik, 1772 körül keletkezett. Leírták még Salix caprea L. tricolor Hort.; és S. caprea L. variegata Hort. néven is [KRÜSSMANN, 1986; TÓTH, 2012].

\section{Salix viminalis L.}

Kender-, kosárkötő- vagy kosárfonó füz, nevezik továbbá nemes füznek is [PRISZTER, 1998]. Szinonim elnevezései: S. longifolia LAM. 1778, S. virescens VILL. 1789, S. rossica NASAROV 1936.

Három-négy méter magasságú, hosszú vesszőjű cserje. Kérge sima, szürkészöld, paraszemölcsös. A fajra jellemzőek a hosszú ízközök, a rügy megnyúlt, lapított, hegyes csúcsú és a szárhoz simuló. A fiatal hajtások szürkés pelyhesek, rajtuk hegyes rügyek találhatók, szintén szörözöttek. A rügyek lombhullás után átlagosan 9 mm hosszúak [ESCHRICH 1981; BARTHA, 1999]. A levél igen hosszú, 10-25 cm, szélessége legfeljebb 1,5 cm. Alakja hosszúkás-lándzsás, keskeny-szálas vagy keskeny, ék vállú, hosszan hegyesedő, széle visszagöngyölödő. A levél a fonákon selymes szőrü, színe zöld, a levélnyél 4-12 mm. A barkák majdnem ülők, a murvapikkelyek oválisak, feketés barnák, szőrösek. A porzós füzérek 2-4 cm hosszúak, a termős füzérek virágzáskor 2,5 cm, terméséréskor 3-6 cm hosszúak. Két különálló porzószála van, a portokok aranysárgák, később barnák. A magház kúpos, szőrözött, a bibeszál hosszú. hosszú. Márciusáprilisban, lombfakadás előtt virágzik [SIMON, 2000; BARTHA, 1999; GENCSI és VANCSURA, 1992; TóтH, 2012]. Diploid (2n: 38) [SoÓ, 1970].

Európától Észak-kelet Ázsiáig, és a Himalájában elterjedt. Folyó- és patakparti bokorfüzesek jellemző faja. Középhegységeink közül a következőkben terjedt el: Tornai-hegység, Mátra, Gödöllői-dombvidék, Vértes, valamint a Bakony szélein. A Dunántúlon Soprontól Somogyig, továbbá az Alföldön is elég gyakori. Eurázsiai flóraelem. Antik idők óta ültetik kosárfonásra, számtalan (kosárfonásra nemesített) fajtája van [SIMON, 2000].

Kapcsolódó fajok, alfajok, változatok, fajták, hibridek:

Salix kiruyanagi KIMURA. A kenderfüzzel feltehetően azonos faj, azonban ennek élőhelye Japán. Az európaihoz hasonló célból termesztik [KRÜSSMANN, 1986].

Salix x helix (Bíborfüz). A kenderfüz csigolyafüzzel (S. purpurea) alkotott természetes hibridje [CSAPODY et al., 1993].

var. viminalis L. f. abbreviata DöLL 1859. A barka szálas-hosszúkás, rövid [SoÓ, 1970]. 
'Cinnamomea' - Barna kenderfüz. Nagyon hosszú, vörösesbarna (fahéj színű) vesszőket nevelö, régi fajta [KRÜSSMANN, 1986; TÓTH, 2012].

'Gigantea' (HARMS) - Óriás kenderfüz. Vesszői megfelelő helyen akár négy méteresre nőhetnek [KRÜSSMANN, 1986; TÓTH, 2012].

'Regalis' - Sárga kenderfüz. Kitünő kötőfüz, 2-3 m-es sárga vesszőkkel. Már 1887 előtt széleskörüen termesztették [KRÜSSMANN, 1986; TóTH, 2012].

\subsection{Salix fajok autovegetatív szaporítása}

Ivartalanul elsősorban fásdugványozással szaporítjuk a füzeket. Folyamatos vízellátás mellett a gyökeresedés gyakran 100\%-os, egyébként a dugványok könnyen kiszáradnak. A meggyökeresedett dugványokon őszig 1-1,5 m-es hajtások is fejlődhetnek [SCHMIDT és TÓTH, 1996].

MAROSI (1886) kosárfonó füzek szaporítására kétféle módszert ismertet: a dugványok ferde (45ํ-os szögben) vagy függőleges elhelyezését a talajban. MAROSI (1886) cikkében idézett KRAHE kutatásai bebizonyították, hogy a ferde elhelyezés semmilyen előnyt nem eredményez a növények számára. Megállapította, hogy az első évben a ferdén talajba helyezett dugványoknak majdnem kizárólag csak az alsó oldalán fejlődtek gyökerek, felső részükön alig, vagy egyáltalán nem. Ezzel szemben a függőlegesen elhelyezett dugványok minden oldalán, csavarvonalban fejlődtek gyökerek. A dugványok hosszméretén túl a vastagságot is vizsgálták, és megállapították, hogy a vastagabb, idősebb (2-4 éves) ágrészekből vágott dugványok az első években jobban fejlődő növényeket, magasabb vesszőhozamot eredményeznek. KRAHE azt tapasztalta, hogy a harmadik évtől kezdve a vékony dugványokból fejlődött tövek terméshozama utolérte az idősebb dugványokból fejlődött növényekét [MAROSI, 1886].

A gyöngybarka (S. rosmarinifolia) szaporításáról TÓTH (2000) annyit ír, hogy fásdugványnyal történik. Ugyanakkor SCHMIDT és TÓTH (1996) szerint a gyenge növekedésű fajokat és fajtákat, köztük a S. rosmarinifolia fajt is, hajtásdugványozással szaporítják, az azévi hosszúhajtások feldarabolásával, melyeket felesleges gyökeresedést serkentő szerekkel kezelni.

A Kelpak ${ }^{\circledR}$ fantázianevü algakivonatot újabban (a 3.2 fejezetben részletezett kísérletet megelőző hónapoktól kezdve) alkalmazzák a gyökerezés serkentésére is, de nincsenek tapasztalatok a dugványok kezelésének (felszívatás) időtartamára vonatkozóan. A Kelpak ${ }^{\circledR}$ az Ecklonia maxima alga kivonatát tartalmazza, és lombpermet formájában növekedést serkentő, hozamnövelő hatását igazolták eddig [MAGYAR et al., 2008; SzABÓ és HrOTKÓ, 2009; KELPAK, 2013]. 


\subsubsection{A kecskefüz gyökeresedésének problémája}

Rosszul gyökeresedő barkafüz a $S$. caprea 'Mas' fajtája, ezért ezt oltani szokták, vagy helyette inkább jól gyökeresedö barkafüzeket (pl. S. daphnoides, S. x smithiana, S. aegyptiaca) szaporítanak [SCHMIDT és TóTH, 1996]. NAGY (1980), és NAGY és SCHMIDT (1991) szerint a 'Mas' fásdugványai nem gyökeresednek. A 'Mas' fajtáról KRÜSSMANN a múlt század második felében írja, hogy a kecskefüz porzós egyedeit illetik ezzel a névvel, és azokat oltással szaporítják, mert nem gyökeresedik [KRÜSSMANN, 1986]. A 'Mas' nem konkrét klón, hanem a porzós formák gyüjtőneve. MAJER (1966) szerint a S. caprea faj nem dugványozható. GENCSI és VANCSURA (1992) szerint a kecskefüz fásdugványai általában nem gyökeresednek, de vannak egyedei, amelyeknél elfogadható gyökérképződés figyelhető meg.

\subsubsection{Barkás vesszők termesztése}

Barkás vesszők termesztésére NAGY és SCHMIDT (1991) a S. caprea 'Mas'-t és egyéb nagy barkájú fajokat tartanak alkalmasnak. Vágótelep létesítésére a Forsythia termesztésétől eltérően nem a faiskolából származó 1-2 éves tövek kiültetését, hanem jól elökészített talajba ősszel vagy márciusban dugványozást, vagy oltványok kiültetését ajánlják. A hosszú $(40-50 \mathrm{~cm})$ simadugványokat 2 x 2 méterre javasolt dugványozni. A nagy térállás célja az árnyékolás negatív hatásának kiküszöbölése, a beárnyékolt vesszökön csak a csúcstól 20-30 cm hosszan fejlödnek barkák, így nem lesznek a kereskedelemben igényelt, teljes hosszukban berakódott vesszők. A 2-3 éves füzekről már 15-20 db, 1-1,5 m hosszú barkás vesszőt lehet szedni. Kopaszfejmüvelésben vagy 2-3 szemes csapokra vágva müvelik, egy hektárról 45-50 ezer szál barkás vessző szedhető, melyeket tízszálas csomókban forgalmaznak. A forgalomba került barkás vesszők ( $S$. caprea) 80-90\%-át vadon gyüjtik [NAGY, 1980; NAGY és SCHMIDT, 1991]. A gyöngybarkáról (S. rosmarinifolia) is azt írja То́тн (2000), hogy „,öbbnyire természetes élőhelyéről kerül a virágüzletekbe”. Móron egy hazai termesztő a következő füzeket termeszti vágó célra: S. eleagnos 'Angustifolia', $S$. hastata 'Wehrhahnii', S. udensis 'Sekka'. Ötven cm-es tö- és egy méteres sortávolságra telepítette a növényeket, de elmondása szerint ennél nagyobb távolságra kellett volna. A telepítést követő 3-4. évtől tud értékesíthető vesszőket szedni, melyeket elsősorban az osztrák és a német piacra szállít. A kereskedelem 10 x 10 db-os kötegekben, háromféle méret-kategóriában igényli a veszszőket: 80-100 cm; 100-120 cm és 180-200 cm hosszúságban. Egy 10 x 10-es, 100-120 cm hoszszú Salix köteg nagykereskedelmi ára 6 euró, kiskereskedelmi ára 21 euró. Hajtatott cserjék tekintetében komoly versenytársaink a lengyel és a román termesztők [ALGEIER, 2010]. Egyéb fás szárú vágott virágok, vesszők termesztéséről, a hazai barkás füzvesszők keresletének és kínálatá- 
nak felméréséröl az M5. mellékletben (140. o.) közlöm eredményeimet és más hasznos információkat.

Az alábbi grafikonon (2. ábra) a holland árverési csarnokokban forgalmazott Salix vesszők mennyisége látható, mely 1996-tól kezdve, egy kisebb visszaesést (2002-2003-ban) követően folyamatosan nö [Bloemisterij, 1997-2009].

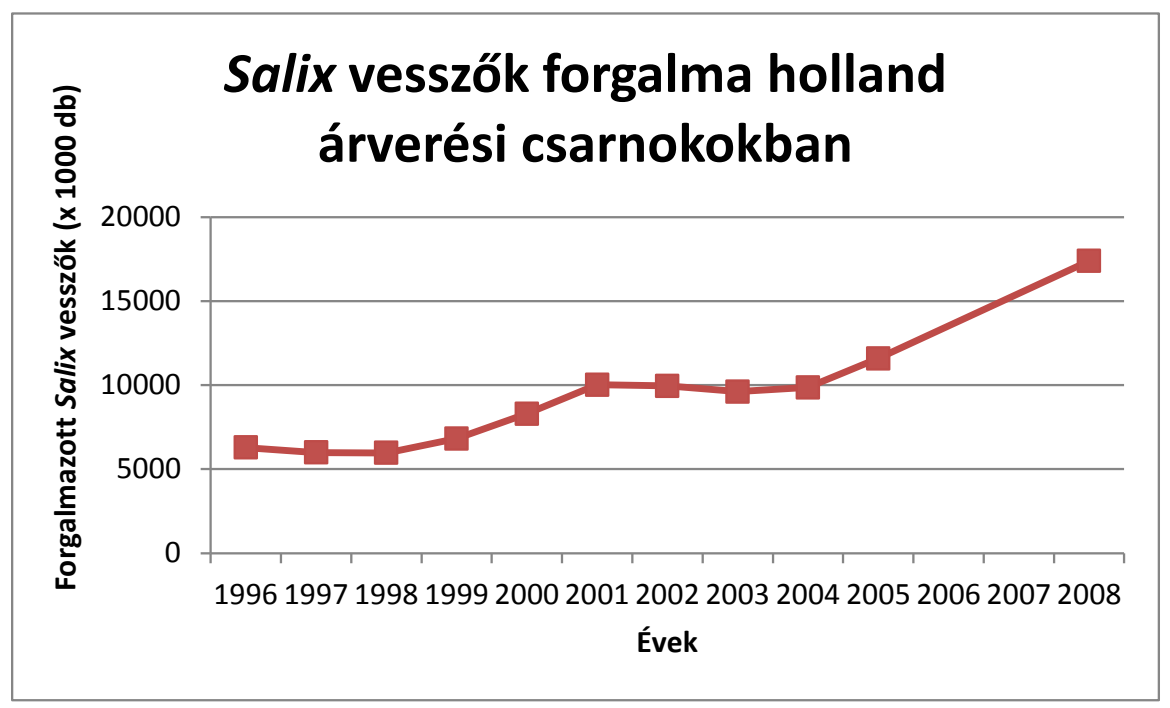

2. ábra: Holland árverési csarnokokban forgalmazott Salix vesszők mennyisége 1996-2008 között (forrás: Bloemisterij)

Füzeket vágási célra Magyarországon a XIX. századtól a kosárfonásra alkalmas vesszőkért termesztettek [MAROSI 1886], a XXI. században pedig az úgynevezett energia-ültetvényekre ültetnek többek között Salix fajokat is. MAROSI (1886) már az 1800-as években sok ma is használható értékes tapasztalatot oszt meg, illetve adatokat közöl füzek vágó célra történő termesztéséröl. Figyelmeztet a nedves, dél felé nyitott völgyekben a korán meginduló növényeket fenyegető fagyveszélyre, mely ilyen tájolású területen a késői fagyok miatt fokozottan fennáll. A $S$. purpurea faj számos hajlékony, oldalhajtások nélküli vesszőt hoz, melyek alkalmasak a fonásra. Ez a faj kötött talajon kevésbé érzi jól magát, legjobban tápanyagban gazdag, üde homoktalajon nevelhető. Általában a kosárfonó füzeket hosszú, legalább $20 \mathrm{~cm}$, de inkább 30-40 cm, tőzeges talajon $50 \mathrm{~cm}$ hosszú dugványokkal szaporítják. Franciaországban szokásos volt a rendkívül sürü dugványozás 150-200 ezer dugvánnyal hektáronként. A német minta szerint ennél nagyobb távolságra dugványozták a szaporítóanyagot, 40-65 ezer dugvány került egy hektárra. Legelőnyösebb a 35-50 cm sortávolság, és a 10-15 cm-es tőtávolság [MAROSI, 1886].

A füzek az időszakos vízborítást és a nyirkos talajt is türik, ezért olyan területeket is ki lehet velük használni, melyek más növények termesztésére alkalmatlanok. A talajmunka elvégzésére a vesszők szedése után, tavasszal van lehetőség. Nyáron a nagy lomb miatt nehéz hozzáférni, de nem is szükséges a talaj árnyékolása miatt [NAGY, 1980]. 
Egy adott Salix klón önálló fajtaként történő elismeréséhez az UPOV irányelvek szerint szükséges vizsgálatok kellenek. A Salix nemzetség vizsgálatához a megkövetelt növényanyagot legalább $1 \mathrm{~cm}$ átmérőjü és $20 \mathrm{~cm}$ hosszú fásdugványok, vagy jól begyökeresedett egy éves növények formájában kell szolgáltatni. Legalább 30 fásdugvány vagy 15 kis növény szükséges a vizsgálatokhoz, melyeket az iránymutatás szerint legalább két önálló növekedési időszakon keresztül kell megfigyelni. Az ültetést követő két év nem számítható be ebbe az időszakba, ekkor ugyanis feltételezhető, hogy a fajtára jellemző tulajdonságok még nem fejeződnek ki kielégítően.

A vizsgálat módjára a következőket írják elő az irányelvek [UPOV, 2003]. Szabadföldön, április elején kell dugványozni $150 \mathrm{~cm}$ x $150 \mathrm{~cm}$ tőtávolságra. A dugványokat párosával kell a földbe tenni, majd a növekedés megindulása után az egyiket el kell távolítani onnan. A megfigyelés céljából homokos, humuszos talajra kell a növényeket telepíteni, trágyázni a talajvizsgálat eredményei alapján lehet. A füzek vizsgálatakor a jellegzetes tulajdonságokat kifejeződésük módja szerint három csoportba sorolják: kvalitatív (QL), kvantitatív (QN), és pszeudo-kvalitatív tulajdonságok (PQ). A kötelezően megfigyelendő jellegzetes tulajdonságok közül néhányat a hozzájuk tartozó példákkal együtt az M4. mellékletben (139. o.) ismertetek.

\subsection{Salix fajok károsítói}

\subsubsection{Salix fajok kórokozói}

\subsubsection{Levél- és hajtáskórokozók}

Vágótelepeken, ahol a növény vesszője az áru, komoly kárt okozhat a füzfa hajtáselhalása. Okozója legtöbbször a Drepanopeziza sphaeroidea (f. acerv. Marssonina salicicola) nevű gomba, esetleg a Glomerella cingulata faj [CsONKA, 2003]. Elsősorban a törékeny füz (S. fragilis) és a fehér füz $(S$. alba), de más füzfajok levelein is gyakori kórokozó a Drepanopeziza salicis tömlősgomba (anamorf: Monostichella salicis). Kórképe a levéllemez színén látható sötétbarna, apró, összefolyó foltok. A betegség következménye az egyes években változó mértékü korai lombhullás. A vegetációs időszak során a levélfoltokban az anamorf forma acervuluszai jelennek meg, melyekben a betegséget terjesztő egysejtü, hialin, 11-17 x 5-7 $\mu \mathrm{m}$ méretü konídiumok tömege képződik. A kórokozó a lehullott levelekben telel át, ahol az ivaros alak mikroszkopikus apotéciumai is kifejlődnek. Az aszkospórák tavasszal, április közepétől szóródnak, a friss lombozatra légáramlatokkal kerülnek. Minden hazai füz fajon előfordul a leveleken és fiatal hajtásokon nekrotikus foltokat okozó Glomerella miyabeana (anamorf: Colletotrichum gloeosporoides). A foltokban nedves időjárás esetén kialakulnak a gomba acervuluszai, később a sötét színü peritéciumok is. A konídiumok egysejtüek, hialinok, hengeresek, méretük 15-22 x 4-5 $\mu \mathrm{m}$. Az aszkospórák egysejtüek, hialinok, elliptikusak, 14-18 x 6-7 $\mu$ m méretüek. A gomba támadása 
következtében a hajtásvégek elszáradnak, a levelek idő előtt lehullanak [SZABÓ, 2008]. A füzfavarasodás (Venturia fajok) föleg a leveleket támadja, de a fertőzés átterjedhet a hajtásvégekre is, melyek meggörbülnek és elszáradnak [VESER, 2003]. A füzeken a $V$. chlorospora (anamorf: Cladosporium sp.) és a $V$. saliciperda (anamorf: Pollaccia saliciperda) fordul elö, és szabálytalan, növekvő, sötét foltokat okoznak a leveleken és a hajtások kérgén. A leveleken fehér bevonatot képező lisztharmatgombák közül a füzeket az Erysiphe adunca támadja, mely különösen a kecskefüzön (S. caprea) gyakori [SZABÓ, 2008; TóTH, 2012].

A különféle füzfajokon több mint 10 rozsdagomba faj (pl. Melampsora allii-fragilis, $M$. galanthi-fragilis.) él, néhol csak a köztesgazda eltérö. A leveleken nyáron a sárga uredotelepek, ősszel a barna teleutotelepek alakulnak ki, melynek következtében (súlyos levélhullás esetén) a hajtások nem fásodnak meg, emiatt télen elfagyhatnak [SCHMIDT és TóTH, 1996; SzABÓ, 2008]. A teleutospórák a lehullott levelekben, áttelelés után csíráznak, és a képződő bazidiospórák fertőzik a köztes gazdákat (pl. Allium, Galanthus fajok), melyek levelein kialakulnak a spermogóniumok és az ecídiumok. Ez ecídiospórák fertőzik vissza a füzeket [SZABÓ, 2008]. A betegség következménye korai lombsárgulás és lombhullás, ezáltal jelentős lehet a növekedéskiesés, az anyatelepeken romlik a dugványkihozatal és a dugványminőség. A vágótelepen jelentkező rozsda a teljes árut tönkreteheti, ha a vesszők elfagynak. Erős fertőzéskor a nagyarányú levélhullásba a növény belepusztulhat. A betegség járványos elterjedése az uredospórákkal történik. Védekezésként júniustól többször rozsda elleni szerrel kell permetezni [SCHMIDT és TóTH, 1996; SZABÓ, 2008].

\subsubsection{Kéregben, fatestben élö kórokozók}

A füzek faszövetében él az Erwinia salicis baktériumfaj, mely a hajtások hervadását, a fák elszáradását okozza. Elsősorban fertőzött, de tünetmentes vegetatív szaporítóanyaggal terjed, továbbá xylofág rovarok is átvihetik egyik fáról a másikra. A tünetek lombfakadást követően jelentkeznek: a hajtások hervadnak, elszáradnak, majd az egész fa elpusztul. Jellemző tünet a fás részek sötétszürke elszíneződése, ami feltűnő foltok képében figyelhető meg a vágási felületen. Az elszíneződött farészeknek jellegzetes szaga van a fakultatív anaerob baktérium fermentatív élettevékenysége következtében. Füzkultúrákban, így barka vágótelepeken is a betegséget a fertőzésmentes szaporítóanyag alkalmazásával lehet megelőzni. A kéregben Valsa (füzeken gyakori

a $V$. salicina, anamorf: Cytospora salicis; esetenként $V$. sordida és más Valsa sp.) és Cryptodiaporthe tömlősgomba-fajok (pl. C. salicella és C. populea) okozhatnak háncsnekrózist. Az utóbbi, Cryptodiaporthe fajok fellépése hazánkban nem gyakori a füzeken. Vesszők és ágak kérgének foltos elhalását idézik elő, különösen stressztényezők (fagy, aszály) hatását követően. A megtámadott ágak kérgében az anamorf piknídiumok fejlődnek ki először, majd később, az 
ágak pusztulását követő évben, de nem minden esetben, kialakulnak a peritéciumok is. Gyengültségi kórokozóként jelenik meg pusztuló vagy elhalt ágakon a narancsvörös sztrómájú Nectria cinnabarina kozmopolita gomba [SZABÓ, 2008].

\subsubsection{Törzs- és tökorhasztó gombák}

Inkább a fatermetü, nagyobb törzset nevelö füzeken, így például a törékeny füzön ( $S$. fragilis) fordul elő számos tő- és törzskorhasztó bazídiumos gomba. Leggyakoribb az évelő termőtestü, fehérkorhasztó parázstapló (Phellinus igniarius) és az egyéves termőtestü, barna korhasztó sárga gévagomba (Laetiporus sulphureus). Gyakori a fehérkorhasztó sokgazdás bükktapló (Fomes fomentarius), és a füzek és nyárak faanyagán élő, szintén fehérkorhasztó ánizstapló (Trametes suaveolens). Idős füzfák tövén a fehérkorhasztó óriás lakkostapló (Ganoderma resinaceum) és a vastagkérgü tapló (G. adspersum) telepedhet meg. Sebparazitaként fertőzhetik a törzseket a következő kalaposgombák: tőkegombák (Pholiota populnea, P. aurivella, P. alnicola var. salicicola), és a kései laskagomba (Pleurotus ostreatus). A törzskorhasztó gombák tevékenységének következtében kiodvasodnak az idős fák törzsei. A legyengült fák gyökereit a gyürüs tuskógomba (Armillaria sp.) támadhatja meg, mely előbb-utóbb a fák pusztulását okozza. A füzek tuskóit, elhalt faanyagát számos szaprotróf taplógombafaj korhasztja, ezek (kezdve a leggyakrabban előforduló fajjal) a következők: fehér egyrétütapló (Funalia trogii), rózsaszínes egyrétütapló (Daedaleopsis confragosa); derestapló (Ganoderma applanatum); pecsétviasz gomba (Ganoderma lucidum); púpos egyrétütapló (Trametes gibbosa); változékony kéreggomba (Schizopora paradoxa); és lilás réteggomba (Chondrostereum purpureum) [SzABÓ, 2008].

\subsubsection{Salix fajok kártevői}

Egy igen korai szakirodalomból a következő idézet szól a (kosárfonás céljára telepített) füzek kártevőiről: „Tudvalevő dolog ugyanis, hogy a füznek igen sok ellensége van, minden fajnak ugyszólva más és más rovar, mely azonban nem minden évben és nem egyformán szokott fellépni. Elegyítés által tehát elérhetjük azt, hogy ha az egyik füzfaj meg is károsittatik, a másik faj megkímélve marad, miáltal a termés részben biztosítva van. Ezenkívül pedig elegyítés által a rovarok szaporodása is többé-kevésbé akadályozva van” [MAROSI, 1886]. A szerző néhány sorral később az utolsó állításokat megcáfolja, mondván, tapasztalatok igazolják, hogy a rovarok az általuk kedvelt faj elpusztítása után átköltöznek a kevésbé kedvelt fajokra is.

Időnként előforduló kártevő a nagy nyárfalevelész (Melasoma populi), ritkábban a kis nyárfalevelész (Melasoma tremulae), lárváik a fakadó rügyeket károsítják, később akár tarrágást is okozhatnak. A lepkék közül a kis éjjeli pávaszem (Eudia pavonia) lárvája károsíthat. A közönséges levélbarkó (Phyllobius oblongus) imágója rügyfakadáskor a rügyeket és a fiatal leveleket 
rágja meg. A fás részeken károsít a fehér kagylóspajzstetü (Chionaspis salicis). Pajzsa sonka alakú, fehér, kissé a kéregbe mélyed, és kidudorodó szegély veszi körül. Erős fertőzése miatt a fiatal növények elszáradhatnak [SCHMIDT és TÓTH, 1996]. A közönséges kagylóspajzstetü (Lepidosaphes ulmi) a vesszőkön telepszik meg [То́тн, 2012]. Szintén az áru díszítőértékét csökkenti, esetleg teljesen tönkreteheti a füzfa boszorkányseprüje (Eriophyes triradiatus). Károsítása következtében a füzfán néhány ág és annak a levélzete deformálttá válik, és ez a torz képződmény télen is megmarad a fán. A vegetációs időben levéltetvek (Aphidoidae) és levéldarazsak (Tenthredinidae) is károsíthatják a füzeket [SCHMIDT és TóTH, 1996]. A gyüjtők, elsősorban azok, akik saját kertjükben vagy földjükön is termesztenek barkás vesszőt, bizonyos fekete levéltetüt emlegettek, mely a növények intenzív növekedésekor, különösen a hajtás csúcsán károsítja a leveleket. Összesen 31, kifejezetten Salix fajokat károsító levéltetü fajt találtam a vonatkozó szakirodalomban. Ezek között azonban kéregtetvek, illetve szürke, barna, piros, zöld, és kékeszöld fajok is vannak [BöRNER, 1957]. Hazánkban a fent említett fekete levéltetü egy Chaitophorus (Chaitophorus salijaponicus), illetve Pterocomma faj (Pterocomma pilosum) lehet [MolNÁR, 2003]. Pterocomma salicis (fekete füz kéregtetü) is előfordul füzeken, Európa-szerte elterjedt. A Chaitophorus salijaponicus (C. niger) a keskenylevelü füzeken, a C. salicti a ráncoslevelü füzek levélfonákán szívogat [DRANSFIELD, 2013].

Barkás vessző termesztés esetén az amerikai szövőlepke és a pajzstetű léphet fel károsítóként az ültetvényekben, ezért ezek ellen a rajzási időben parathionos permetezéssel kell védekezni [NAGY, 1980; NAGY és SCHMIDT, 1991].

A nagy farontólepke (Cossus cossus L.) hernyója előnyben részesíti táplálkozásakor a füzés nyárfákat. Ezért, bár polifág faj, újabban használt magyar neve: füzfarontó lepke. A hernyó a gyümölcsfákat is károsítja, különösen a mandulát. A lepke tojásrakásnál a beteg, sérült, öreg fákat részesíti előnyben, elsősorban olyan ültetvényekben, vagy azoknak olyan részein telepszik meg, ahol a fák kondíciója eleve gyengébb. Nagyobb mennyiségben való előfordulásakor a fák egy részének részleges vagy teljes pusztulását okozhatja, ez azonban Magyarországon nem jellemző. A hernyó többnyire idős fák törzsében él, az erősen fertőzött részek szivacsszerűen lyukacsosak az elliptikus keresztmetszetű járatoktól [BALÁZS és MÉSZÁROS, 1998].

A vesszők értékét több gubacsképző kártevő ronthatja. A gubacsatkák két nemzetségének (Aceria és Vasates) több faja okozhat különböző alakú gubacsokat a leveleken és a hajtásokon [LAKATOS, 2008]. A Stenactis triradiatus és Aculus tetanothrix gubacsatkák szívogatásától torzulások, seprüsödések, deformációk, gubacsok jelennek meg a hajtásokon, leveleken, virágzatokon [То́тн, 2012]. A gubacsszúnyogok családjából a Rhabdophaga rosaria a rügyeket támadja, és a kihajtó levelek összezsúfolódását okozza; a $R$. salicis a hajtásokon okoz duzzanatokat; a $R$. saliciperda az ágak kérgén képez gubacsot [LAKATOS, 2008]. A füzrontó gubacsszúnyog 
(Helicomyia saliciperda) megvastagodásokat okoz az ágakon, vesszőkön [TótH, 2012]. Darazsak is képeznek gubacsokat a füz fajokon, elsősorban a Pontania vesicator, a $P$. dolichura és a P. proxima fajok, melyek különböző méretü, pirosas-lilás színü hólyagos gubacsokat képeznek a leveleken [LAKATOS, 2008].

A cinegefüz (S. rosmarinifolia) károsítóiról KISS (1944) írt részletesen. Emberi kártételként utal a lopásra, mivel különösen a XX. század első felében igen tartós és jó seprüt kötöttek ebből a fajból. Gerinces állatok nemigen fogyasztják, a legeltetett szarvasmarha és az őz csak akkor rágja le, ha nem talál füvet vagy akácsarjat. Nyulak egyáltalán nem károsítják. Levelét a Leucoma salicis hernyói rágják éjjel, nappal a levelekből készített csőben pihennek, és itt rejtőznek el ellenségeik elől. A Phillodecta vitellina is károsíthatja a leveleket. Legveszélyesebb kártevője a kallócserebogár (Polyphylla fullo L.), szinte alig találni olyan cinegefüz gyökeret, melyet ne rágott volna meg a pajor. Az ágak legnagyobb kártevője a Sesia forciaeformis Esp. Az idősebb ágakra rakott petéből kikelő lárva berágja magát a bélszövetig, ott a farészt megtámadja, és akár 8-9 cm hosszú, 2,1 mm átmérőjü járatot készít magának. Valószínüleg ez a kártevő az oka annak, hogy a cinegefüz töveken csak ritkán lehet hat évesnél idősebb ágakat találni. Pajzstetvek és gubacsszúnyogok is károsíthatják [KISS, 1944].

\subsection{Nyílasztás - a növények nyugalmi állapotára ható tényezők}

A nyillasztás valójában az az eljárás, mikor a bimbós állapotban szedett vágott virágokat vagy vesszőket megfelelő nyílasztó oldatba állítva, és a szükséges egyéb körülményeket biztosítva (legalább 2000 lux megvilágítás, $20-25^{\circ} \mathrm{C}$ körüli hőmérséklet, 100\% relatív páratartalom) mesterségesen elérik azt, hogy a bimbók teljesen, és akár gyorsabban is kinyíljanak, mint ha a tövükön maradtak volna [SCHMIDT, 2002]. Az eljárást végezheti a termesztő vagy a nagykereskedő is. Orgona és aranyvessző ágak nyílasztása régóta gyakorlat, a többi vágott virág (pl. szegfü, krizantém, rózsa, papagájvirág, kardvirág) nyílasztásának technológiája az 1980-as években indult fejlődésnek [NOWAK és RUDNICKI, 1990].

Hajtatásnak vagy korai virágoztatásnak nevezik azt, amikor valamilyen, hazánkban szabadföldön is termeszthető (kiültethető) növényt a természetben megszokott, általában tavaszi vagy nyári nyílásától eltérő, korábbi időpontban késztetnek virágzásra. A gyakorlatban nem tesznek különbséget a hajtatás és a korai virágoztatás között, a pontos terminológia szerint azonban ezek nem tekinthetők egymás szinonimájának. Valódi hajtatás, ha a növény rügyeiben (hagymájában) még a kihajtás előtt kialakulnak a virág kezdeményei, és ezt kényszerítik idő előtti (téli vagy kora tavaszi) kihajtásra. A fényerősség ebben az esetben másodlagos szerepet játszik (a minőség javításához lehet szükséges; a levelek és szirmok színeződéséhez), mert a már 
kialakult virágkezdemények jórészt a növény tartalék tápanyagaiból fejlődnek ki. Hajtatják a legtöbb tavaszi hagymás virágot, például a tulipánt, jácintot, nárciszt, a fásodó vagy fás szárúak közül a hortenziát és az orgonát. Korai virágoztatásnak azt az eljárást nevezik, mikor a virágok differenciálódását is mesterséges körülményekkel segítik elö, mert a rügyekben még csak vegetatív részek alakultak ki, virágkezdemény nem. A virágoztatás során a virágok csak később, a folyamatosan növekedő új hajtások végén fognak kialakulni, majd kinyílni. Korai virágoztatást alkalmaznak a növényházi vágottrózsa-fajtáknál, és több trópusi, szubtrópusi származású hagymás vagy hagymagumós növénynél, mint például a kardvirág, kánna, dália, inkaliliom, és liliom. Ebben az esetben a virágok differenciálódásához hosszú nappal, és viszonylag erős megvilágítás szükséges [SCHMIDT, 2002]. NAGY (1986) még nem definiálta ilyen pontosan a virágoztatás és hajtatás fogalmait, szinonimaként alkalmazta a két kifejezést.

A fás szárú, szabadföldön nevelhető növények virágos vesszőit már a régi idők emberei is hajtatták, ilyen például a hagyományosan Szent Borbála napján (december 4-én) szobába vitt, vázába tett cseresznye ág, mely jó esetben Karácsonyra kivirágzott. RUPPRECHT (1966) Aesculus hippocastanum L. és Forsythia x intermedia Zabel. levágott ágainak, vesszőinek virágoztatásáról ír. NAGY (1986) a következő fajok vesszős hajtatását részletezi: Syringa vulgaris, Forsythia x intermedia, Salix caprea 'Mas', Salix smithiana, Prunus triloba 'Multiplex', Malus hibridek, Prunus serrulata fajták, Deutzia, Chaenomeles, és Aesculus fajok és fajták, és Viburnum opulus 'Roseum'. A fák és cserjék hajtatása, virágoztatása csak a növények mélynyugalmi szakaszát követően lehetséges. A korai vesszős hajtatáshoz vernalizálásra is szükség lehet, mely már novembertől végezhető hütőkamrában mínusz $2-5^{\circ} \mathrm{C}-$ on, $90-95 \%$ relatív páratartalomban, 3-4 héten át. Korai (október végi) vesszőszedéskor lombtalanítás válhat szükségessé, ha az ősz meleg, fagymentes volt. Ehhez a vesszőket benedvesítve, fóliaborításban, $20^{\circ} \mathrm{C}$-on, 2-3 napig fülleszteni kell, ezután a levelek lerázhatók. A virágoztatáshoz tartósító, fertőtlenítő hatású- és tápanyagokat tartalmazó oldatba (pl. AKN-oldat) javasolt a vesszők állítása. A kivirágoztatás optimális hőmérséklete a virágoztatás időpontjától is függ: január elején $18-20^{\circ} \mathrm{C}$, január közepétől $16-18^{\circ} \mathrm{C}$. A kivirágoztatás időtartama általában 10-14 nap, az orgonáé meghaladhatja az egy hónapot is. A sikeresen virágoztatott vesszők tárolása 5 , jobb esetben $0,5^{\circ} \mathrm{C}$-on lehetséges [NAGY, 1986].

\subsubsection{Nyugalmi állapot}

A növények növekedése és fejlődése nem folyamatos, nem egyenletes, a mérsékelt égövben bizonyos időszakokban teljesen szünetelhet is, vagyis nyugalmi szakaszok szakítják meg. Az évelő lombhullató fás növények fejlödési fázisai évenként ismétlődnek. Nyugalmi állapotuk a téli hónapokra esik, és feloldását, valamint a tavasszal virágzó növények nyílását a nappalhoszszúságon túl a hőmérséklet befolyásolja jelentősen. KLIPPART már 1874-ben megállapította, 
hogy egyes fajok esetében a virágzás szempontjából az alacsony hőmérséklet a döntő tényező, melyre bizonyos ideig szükségük van a növényeknek [KLIPPART, 1874]. A növények hidegigényét először GASSNER (1918) vizsgálta tudományosan [SZALAI, 1974].

A nyugalmi állapot magvas növények esetében legnagyobbrészt az embrionális szövetekre, vagy ilyen szöveteket tartalmazó szervekre vonatkozik. Tehát a magokban lévő embriók, a hajtások csúcsmerisztémái, - elsősorban a kambium - lehetnek nyugalmi állapotban [SzALAI, 2001].

A növények növekedés-szabályozására és a nyugalmi állapotra vonatkozó kutatásokban új távlatok nyíltak azáltal, hogy az utóbbi időkben genom alapú megközelítéssel sikerült sokat megérteni a hormonok létfontosságú fiziológiai folyamatokra, mint például a sejtosztódásra gyakorolt hatásáról [HORVATH et al., 2003].

LANG et al. (1987) a nyugalmi állapotokat a következőképpen csoportosították:

(i) látszólagos nyugalmi állapot (paradormancy): a növekedés távoli szervek általi gátlása, amikor a kiváltó tényező a szabályozott struktúrán kívülröl ad jelzést;

(ii) endogén nyugalmi állapot (endodormancy): a növekedés rügyön (vagy más szabályozott struktúrán, pl. magon) belülről érkező jelzések általi gátlása;

(iii) környezeti nyugalmi állapot (ecodormancy): a növekedés ideiglenes kedvezőtlen külső környezeti tényezők általi gátlása. Ezek a jelenleg elfogadott tudományos fogalmak a nyugalmi állapot jellemzésére, de ez a terminológia nincs mindig összhangban a kertészek gyakorlatban használatos fogalmaival [НROTKÓ, 1999]. A látszólagos nyugalom típusát tanulmányozták a legtöbbet a háromféle nyugalmi állapot közül, és apikális dominancia vagy korrelatív gátlás néven is emlegetik [HORVATH et al., 2003].

A nyugalom vizsgálatakor két fó nehézséggel kell szembenézni: az egyik, hogy ez egy dinamikusan változó folyamat, a másik, hogy több fázisra különíthetö, melyek között az átmenet sem mindig egyértelmü [SCHOOT, 1996].

\subsubsection{Rügyek nyugalmi állapota}

A rügyek nyugalmi periódusában elö-, mély- és utónyugalmat különböztetünk meg, amelynek időbeli eloszlása és tartama fajok szerint változik. A tavaszi cserjék, köztük a Salix fajok rügyeinek mélynyugalma is a nyár második felére esik és korán véget ér. A rügyfejlődés előnyugalomnak nevezett állapotában a vegetációs időben fejlődött csúcs- és oldalrügyek növekedését az érett levelek hormonálisan gátolják, a rügy fejlődését mintegy lelassítják. Előnyugalomban a levelek eltávolításával a rügyek növekedése megindul. Ellenkező esetben bekövetkezik a következő állapot, a mélynyugalom [SZALAI, 2001; SzALAI, 2009]. Ez utóbbit endogén tényezők tartják fenn, ezért már nem oldható fel a külső feltételek megváltoztatásával. A virágrügyekben ilyenkor - nem túl alacsony hőmérséklet esetén - egyes virágrészek differen- 
ciálódása még folyik. A mélynyugalmat követően - megfelelő külső körülmények között - a rügyek növekedésnek indulnak. Rossz külső körülmények esetén azonban utónyugalomban maradhatnak még egy ideig. Hazánkban az alacsony hőmérséklet következtében az utónyugalom gyakran kényszernyugalomba megy át [SZALAI, 1974].

LÖRINCZ (1999) a szőlőrügyek nyugalmi periódusát öt jól elkülöníthető szakaszra osztja. Első a nyugalmat megelőző (feltételes nyugalmi) fázis, melynek kezdetekor a rügyek már fakadóképesek, de nem hajtanak ki a tenyészőcsúcsok és lomblevelek általi korrelációs gátlás következtében. Szőlőnél ez augusztus első dekádjának végéig tart. Ekkor még megszüntethető a nyugalom a nyári rügyek, a fö- és hónaljhajtások csúcsi részének, vagy a levelek eltávolításával. A nyugalomba lépés fázisa augusztus második dekádjától szeptember végéig tart. A rügyek a hajtás tövi részétől kiindulva lépnek be ebbe a fázisba. A kifejlett levelek és a rügyek abszcizinsavat (ABS, dormin) kezdenek termelni, ami felhalmozódva gátolja a rügyek kihajtását. A mélynyugalom szőlőnél augusztus végétől szeptember végéig tart, ekkor a rügyekben jelentős mennyiségü abszcizinsav található. A negyedik a nyugalomból ébredés fázisa, mely szőlőnél október elejétől vagy közepétől decemberig tarthat. Kezdetét az jelzi, hogy a rügyek fakadásához szükséges idő rövidülni kezd. A rügyek ABS tartalma erősen csökken, végül teljesen lebomlik. Októbertől március-áprilisig tart a nyugalom utáni fázis (kényszernyugalom), mikor a rügyek csak a kedvezőtlen időjárás miatt maradnak nyugalomban. Míg az előző három fázisban endogén tényezők okozzák a nyugalmat, ez úgynevezett exogén nyugalom, mikor a gátlás eredete az időjárásra vezethető vissza, kiváltó oka elsősorban az alacsony hőmérséklet [LŐRINCZ, 1999].

\subsubsection{Rügynyugalomra ható tényezők}

\section{Nappalhosszúság}

Régebben a növekedés leállását és a mélynyugalom létrejöttét a rövid nappalhosszal magyarázták. Megállapították, hogy hosszúnappalos feltételek között a legtöbb faj vegetatívan fejlődik, míg rövidnappalon kialakul a rügynyugalom. A magoncok érzékenyebben reagálnak a sötét periódus hosszára, ezért annak rövid idejü megvilágítással történő megszakítása hatástalanítja stimuláló hatását, és késlelteti a nyugalmat. Ilyen szempontból a spektrum vörös tartománya a leghatásosabb, ami arra enged következtetni, hogy a rügynyugalom kialakulásában szerepe van a fitokróm-rendszer reverzibilis változásainak. A nappalhosszúság évszakos változását fontos tényezőnek tartották a nyugalmi állapot kezdetének meghatározásában. Ezt olyan fajok esetében mutatták ki, melyek magoncai még ősszel is intenzíven növekedtek. Számos faj esetében azonban a kifejlett, idősebb példányok éves növekedése hamarabb lezárul, mint ugyanazon faj esetében a magoncé. Ezen idősebb egyedek növekedésüket gyakran már nyár közepén, még hosszúnappalon beszüntetik. Mivel a mérsékelt égövön, természetes körülmények között a növekedés 
leállása és a rügyképzödés leggyakrabban nyáron történik, a nappalhossz jelentősége vitatottá vált. Valószínübb, hogy valamilyen anyagcsere-változás, például a tápanyag mennyiségének vagy a hormonális egyensúly megváltozása határozza meg a növekedést és egyben a nyugalom kezdetét. A kezdeti előnyugalomból a rügy fokozatosan tér át a mélynyugalomba. SzALAI (1974) szerint lehetséges, hogy az őszi rövidülő nappalok az átmenet kialakításában jutnak szerephez. A nappal mesterséges megrövidítésével egyes fák lombhullása fokozható, ugyanakkor például az erős fényü utcai lámpák közelében, mintegy „mesterséges hosszúnappalon” a lombozat jóval tovább megmarad. A természetben valószínüleg az alacsony hőmérséklet és a gyengébb fényintenzitás együttesen meghatározói a levelek öregedésének és lehullásának. A látható morfológiai változások a rövidnappalos fotoperiódus nyugalmat indukáló hatásával együtt olyan biokémiai folyamatokat váltanak ki, amelyek emelik az egyed hidegtürését, ezzel együtt az abszcizinsav hormon szintjének növekedése elősegíti a növény alkalmazkodását a számára kevésbé kedvező ökológiai körülményekhez [SZALAI, 1974]. A fénynek és a hőmérsékletnek egyaránt jelentős szerepe van az endogén nyugalom kialakításában és megtörésében. A legtöbb fásszárú évelő növény esetében a fény játssza a döntő szerepet. A lombhullató fáknál a csökkenő nappalhosszúság megváltoztatja a csúcsrügyek fejlödését, és azt eredményezi, hogy a levélkezdeményekböl rügypikkelyek fejlődnek levélrügyek helyett [OKUBA, 2000]. A papírnyír (Betula papyrifera Marsh.) és az amerikai rezgő nyár (Populus tremuloides Michx.) esetében megfigyelték, hogy további változások is zajlanak, melyek elősegítik a télállóságot, a sejtosztódás leállítását, és a nyugalmi állapot kiváltását a terminális merisztémákban [LI et al., 2003; PETRIDES és WEHR, 1998]. Ugyanígy a nyugalom végét, a rügyek kihajtásának időpontját is szabályozza a hőmérséklet és a nappalhossz alakulása. A tavaszi fejlődés kezdetének időzítése a fák esetében mindig egyfajta kompromisszumot jelent a hosszabb növekedési időszak, és a késői fagyok miatt bekövetkező károk veszélyének csökkentése között. A fejlődés ütemét közvetlenül befolyásolja a hőmérséklet, de mivel az időjárásban igen nagy az éven belüli változékonyság, a növekedési időszak, és ezáltal a fagyveszélynek kevésbé kitett időszak alakulására a hőmérséklet változása önmagában igen gyenge jelzőrendszernek bizonyulna. Ezzel szemben a nappalhosszúság egy megbízható, és az időjárástól független jelzőrendszer a növekedési időszak alakulására. BASLER és KORNER (2012) klímaszobában végzett kísérletekkel mesterséges tavaszi viszonyok között a rügyfakadás fotoperiodikus érzékenységét vizsgálták 14 európai fafaj dugványain, melyek különböző élet-stratégiai típusokhoz tartoznak (pionírok vagy exóták, illetve őshonos, a szukceszszió folyamán későbbi stádiumban megjelenő fajok; 3 fenyőféle és 11 zárvatermő növény). Megfigyeléseik szerint a rövidnappalos hatás késleltette a rügyfakadást öt szukcesszióban késői stádiumú faj esetében, míg a szukcesszió folyamán korábbi stádiumban megjelenő fajok esetében nem mutattak ki határozott érzékenységet a nappalhosszúságra. 


\section{DOI 10.14267/phd.2014004}

\section{Hőmérséklet}

Jelenlegi tudásunk szerint a hőmérséklet bizonyul a nyugalmi állapotot befolyásoló legfontosabb tényezőnek. Szabályozza a rügyfakadás idejét, és hatással van a különböző nyugalmi állapotok (elö-, mély- és kényszernyugalom) egymásba való átalakulására [CRABBÉ és BARNOLA, 1996]. Ugyanakkor a hőmérséklet nem tökéletes jelzőrendszer a növények számára, mivel a növények esetében nem beszélhetünk hőreceptorokról, mint amilyenek a fény esetében a fitokrómok. A hőmérséklet befolyásolja a membránok fizikai állapotát, az enzimatikus reakciók sebességét, a kompartmentizációt, valamint az anyagcsere-folyamatokat. A hőmérséklet hatására bekövetkezett változások tehát nem definiálhatók egyértelmüen, fajonként változnak, és a fiziológiai környezettől is függnek. Kísérletekkel igazolták, hogy a rügynyugalom időszakaiban a 0$10^{\circ} \mathrm{C}$ közötti hömérséklet a rügyek mélynyugalomban eltöltött idejét növeli, illetve egyes esetekben csökkentheti is [MAUGET, 1981]. Sőt, bármely hőmérséklet, eltérő hatékonysággal ugyan, de képes lehet a rügynyugalom fokozására, csökkentésére, vagy a nyugalmat követően a rügyfakadás előidézésére [LAVARENNE et al., 1980]. Egy új tanulmány arra hívja fel a figyelmet, hogy ne tulajdonítsuk kizárólag a hőmérsékletváltozás hatásának a magasabb lombkoronaszintben lévő fák későbbi lombosodását (az alacsonyabb szinteken élő fák kihajtásához képest), és arra mutat rá, hogy ennek oka elsősorban ontogenetikus eredetü [VITASSE, 2013]. A magas kőris (Fraxinus excelsior L.) esetében például a $0-10^{\circ} \mathrm{C}$ közötti hömérséklettartomány hatékony a nyugalmi állapot fenntartásában, majd később annak megszakításában. Ugyanebben a hőmérsékleti intervallumban azonban a nyugalmi állapot végét követően már lassú a növekedés. A $10-15^{\circ} \mathrm{C}$ közötti hömérséklet minden rügyállapotnak kedvez, a $15^{\circ} \mathrm{C}$ felett tartott növények esetében a mélynyugalom hosszabb ideig tartott, mint a természetes (téli) körülmények között lévő növények esetében [Mauget, 1983; Mauget és Rageau, 1988]. A rügy típusától is függ a hidegigény. RaLlo és MARTIN (1991) szerint a virágrügyeknek van hidegigényük, a hajtásrügyeknek nincs.

A rügy fiziológiai fejlődése a kényszer-, elő- és mélynyugalom alatt meghatározza a válaszreakciót a hőmérsékletre. Egy adott hőmérsékleti tartományban a hirtelen változás mérsékelheti vagy gyorsíthatja a rügy spontán fiziológiai változásait. Számos fontos elméleti és gyakorlati következménye lehet ezeknek a változásoknak. A rügy pontos fiziológiai állapota ugyanis még szabályozott hőmérsékletü kísérleti körülmények között sem ismert, valamint nem tisztázott a hőmérséklet hatása az egyes sejtek metabolizmusára sem. CHAMPAGNAT (1983, 1992), WiLLIAMS et al. (1979), valamint MAUGET és RAGEAU (1988) megállapították, hogy a terminális rügyek nyugalma mélyebb, de könnyebben felszabadulnak belőle, mint az oldalrügyek. Ugyanakkor nem tisztázott a kérdés, hogy azonos alacsony hőmérséklet hatására miért szakad meg könynyebben egy terminális rügy mélyebb nyugalmi állapota, mint egy kevésbé mély nyugalomban lévő oldalrügyé. Szintén probléma, hogy a mélynyugalom vége és a rügyfakadás ideje nem hatá- 
rozható meg precízen egyetlen klímán sem. Ugyan készültek már elméleti és statisztikai modellek az elörejelzésre [BIDABÉ, 1967; RICHARDSON et al., 1974; KOBAYASHI et al., 1982; SHALTOUT és UNRATH, 1983], de ezek csak meghatározott klimatikus, és szélsőségektől mentes időjárási körülmények között müködnek [LANG, 1996].

Enyhe tél esetén a nyugalmi állapot lezajlása még mindig nem tisztázott, azt azonban tudjuk, hogy ilyen körülmények között a nyugalom kevésbé mondható mélynek, mint a hidegebb telü területeken. Kevésbé mély nyugalmi állapot esetében számos, a rügyfakadásra ható korrelatív tényezővel kell számolnunk a tél folyamán [HERTER et al., 1991].

\section{Vernalizáció}

A lehüléssel létrehozott változások összességét vernalizációnak (szinonim: jarovizáció) nevezzük. SzALAI (1974) vernalizáláson azt a lehülést érti, amellyel lehetséges a természetes téli hideget helyettesíteni, és a virágkezdemények későbbi képződését kiváltani. A vernalizáció kvantitatív folyamat, azaz - egy bizonyos pontig - minél hosszabb a vernalizáció időtartama, annál erőteljesebb a virágképződés [METZGER, 1996]. Sok faj virágkezdeményei nem a lehütés periódusában keletkeznek, hanem a lehütést követő magasabb hőmérsékleten. A magas hőmérséklet megsemmisíti a lehütés hatását, például vernalizált rozst 1 napos $35^{\circ} \mathrm{C}$-os meleggel devernalizálni lehet, majd újabb alacsony hőmérséklettel revernalizálható [SzALAI, 1974]. Az alacsony, de fagypont feletti $\left(0-10^{\circ} \mathrm{C}\right.$ közötti) hömérséklet a nappalhossz mellett az egyik legfontosabb környezeti inger a nyugalom szempontjából. METzGER (1996) szerint a fagypont alatti hőmérséklet általában nem hatékony a vernalizáció szempontjából. Ugyanakkor HENZELL et al., (1991) szerint hosszabb lehülés vagy fagypont alatti hömérséklet szükséges gyakran ahhoz, hogy az endogén nyugalmi állapot megszünjön, de vegyszerekkel, mint például a hidrogén-ciánamid (HC) is meg lehet azt törni [HENZELL et al., 1991]. Bár a nyugalom HC általi megtörésének mechanizmusa még ismeretlen, arra már van bizonyíték, hogy ebben sejtszinten egy SNF-szerü kináz fehérje ( $\mathrm{SNF}^{1}$ like protein kinase) játszik szerepet [OR et al., 2000].

Víz

A víz kulcsszerepet játszik a rügyek viselkedésében. Kényszernyugalomban lévő rügyek növekedésének elindításához gyakran elegendő őket vízzel megöntözni. A trópusokon a növekedés leállását a száraz és nedves időszakok váltakozása okozza, de a belső vízháztartásra közvetlen befolyással van a levélnövekedés és a levélhullás is [BORCHERT, 1991]. Az viszont kérdéses, hogy a száraz időszak előidézhet-e valódi mélynyugalmat. DREYER és MAUGET (1986) dióval (Juglans regia L.) végzett kísérleteikkel bebizonyították, hogy a tavaszi növekedés alatt a drasz-

\footnotetext{
${ }^{1}$ Az SNF az angol „sucrose-nonfermenting” rövidítése, a szakirodalomban minden nyelvben az angol megnevezés használata elterjedt.
} 
tikus, rövid ideig tartó (2-3 hét) szárazság azonnali növekedésleállást okoz. A folyamatos vízellátásban részesülő növényekhez képest ezeknél a tavasszal kényszernyugalomba kerülő növényeknél megváltozott az őszi mélynyugalom. Novemberben mélyebbnek bizonyult a rügynyugalom azokon a hajtásokon, melyek növekedése leállt a tavaszi kényszernyugalomban, mint a szárazság után képződött hajtásrészeken lévő rügyek nyugalma.

\section{Növekedésszabályozó anyagok}

Számos egyéb, kevéssé tanulmányozott tényező is hatással van a növény nyugalmi állapotának kiváltására és megszakítására. Az exogén növekedésszabályozó anyagok hatása főként a kijuttatás időpontjától függ. A cseresznyefa rügyei például fiziológiai fejlettségüktől függően reagálnak a felületükre kijuttatott növekedésszabályozó anyagokra [ARIAS és CRABBÉ, 1975].

A növényi hormonok is sokféleképpen hatnak a mélynyugalomra. Ismert például az abszcizinsav mélynyugalmat kiváltó és fenntartó hatása. Ezzel ellentétesen hatnak a gibberellinsavak, melyekkel (a megfelelö időben és koncentrációban) a mélynyugalom megtörhető. A citokininek szintje a rügyekben a rügypattanást megelőző időszakban és rügypattanáskor a legmagasabb. Természetesen nem lehet az egyes hormoncsoportokat elkülönítve kezelni, hiszen hatásuk a rügynyugalomra - mint minden más élettani jellemzőre - nem individuális, hanem összetett, szinergista vagy antagonista jellegü [SZALAI, 2007]. Egy fás peónia fajta tavaszi és őszi virágzására vonatkozó kutatásban folyamatosan mérték a növényi hormonok szintjét a fejlődő tavaszi, illetve őszi virágrügyekben. Megállapították, hogy az őszi virágrügyek fejlődése során nőtt a növényekben az indolecetsav (IES) és a gibberellinsav $\left(\mathrm{GA}_{3}\right)$ szintje, míg az abszcizinsav hormon mennyisége csökkent. Megállapították, hogy az ősszel is virágzó 'AoShuang' fajtánál az őszi virágrügyek fejlődése az alacsony abszcizinsav-szintből adódó nyugalmi állapot hiányának köszönhető [MORNYA et al., 2011].

A gibberellineknek jelentős szerepük van télen a rügyek nyugalmi állapotának megszakításában [SCHMIDT, 2002]. Számtalan kutatás és kísérlet bizonyítja a gibberellinek kedvezö hatását a virágoztatásra, esetenként a virágok méretének és számának emelkedésére is. YANG és READ (1997) fásdugványokon vizsgálták a nyílasztó (hajtató-) oldatban lévő gibberellinsav (1-50 mg $\mathrm{GA}_{3} / \mathrm{l}$ ), a benziladenin (1-100 mg BA/l) és az indol-vajsav (1-25 mg IVS/l) hatását a rügynyugalom megtörésére, majd ezt követően a hajtás megnyúlására. Megállapították, hogy a $\mathrm{GA}_{3}$ és a BA növelte a rügyfakadást, és pozitív hatással volt a hajtások növekedésére is. Az IVS csökkentette a rügyfakadás mértékét, és késleltette is azt. A fajok közt kis különbségek voltak megfigyelhetők a rügyfakadás százalékos arányában, a rügyfakadásig eltelt napok számában, valamint a hajtásnövekedés mértékében. FOLHOFFER (2005) hajtatási kísérleteiben a fertőtlenítőszeren kívül gibberellinsavat és cukrot adott az oldatokhoz. Gibberellinsavat minden esetben 3,5 mg/ml 
mennyiségben alkalmazott. Vágott virágok vázaélettartamának növelésére NowAK és RUDNICKI (1990) a gibberellinsavat 1-400 ppm koncentrációban ajánlja. A gibberellinsav további felhasználásáról dísznövények hajtatása során az M6. mellékletben (150. o) közlök adatokat.

\subsubsection{A nyugalmi állapot molekuláris biológiai háttere}

A növekedésszabályozásra és hajtásfejlődésre vonatkozó kutatások során számos gént azonosítottak, melyek a merisztéma iniciálódásban és a szervek alakulásában vesznek részt, és számos olyan gént és jelzést, melyek a sejtosztódásra hatnak a növényekben. A felmerülő kölcsönhatás a rügyek nyugalmi állapota és a sejtosztódás (rügyek növekedése és fejlődése) között arra utal, hogy ennek a két alapvető folyamatnak a szabályozása azonos jelrendszeren keresztül történik [HORVATH et al., 2003].

A nyugalmi állapot megtörését követően a vegetatív rügyek növekedése specifikus hormonok hatásához kapcsolódik, és gyakran megnövekedett sejtosztódással jár együtt. A sejtciklusspecifikus gének kifejeződésében változások zajlanak a rügyek nyugalmi állapotból való kilépésekor, például borsó (Pisum sativum L.) és burgonya hónaljrügyeinél, valamint a sárkutyatej (Euphorbia esula L.) és a csicsóka (Helianthus tuberosus L.) járulékos rügyeinél [DEVITT és StAFSTROM, 1995; CAMPBELl et al., 1996; Horvath et al., 2002; FreEMAN et al., 2003].

Az eukarióta sejtek növekedése és osztódása jól megkülönböztethető fázisokra osztható, melyek összessége alkotja a sejtciklust. A sejtciklus alapvetően a sejtosztódásból (mitózis), és az azt megelőző interfázisból áll. Az interfázis további szakaszokra osztható, melyeket G1, S, és G2 fázisnak nevezünk [VeLICH, 2001]. A sejtek a G1 fázisban növekednek és készülnek a DNSreplikációra, mely az $\mathrm{S}$ fázisban történik. A DNS replikációt követően a sejt a G2 fázisba lép, és tovább növekszik, valamint felkészül a mitózisra [HORVATH et al., 2003]. A növényekben a nem-osztódó sejtek a G1-S fázis átmenetben, közvetlenül a DNS replikáció előtt, vagy a G2fázis és mitózis közötti átmenetben, közvetlenül a sejtosztódás előtt is beszüntethetik növekedésüket [BOER és MurRAY, 2000]. A legtöbb esetben úgy tünik, a vegetatív rügyekben és a hajtásokban lévő sejtek a G1 fázisban függesztik fel növekedésüket, közvetlenül a sejtciklus $\mathrm{S}$ fázisa előtt [GUTIERREZ et al., 2002]. 


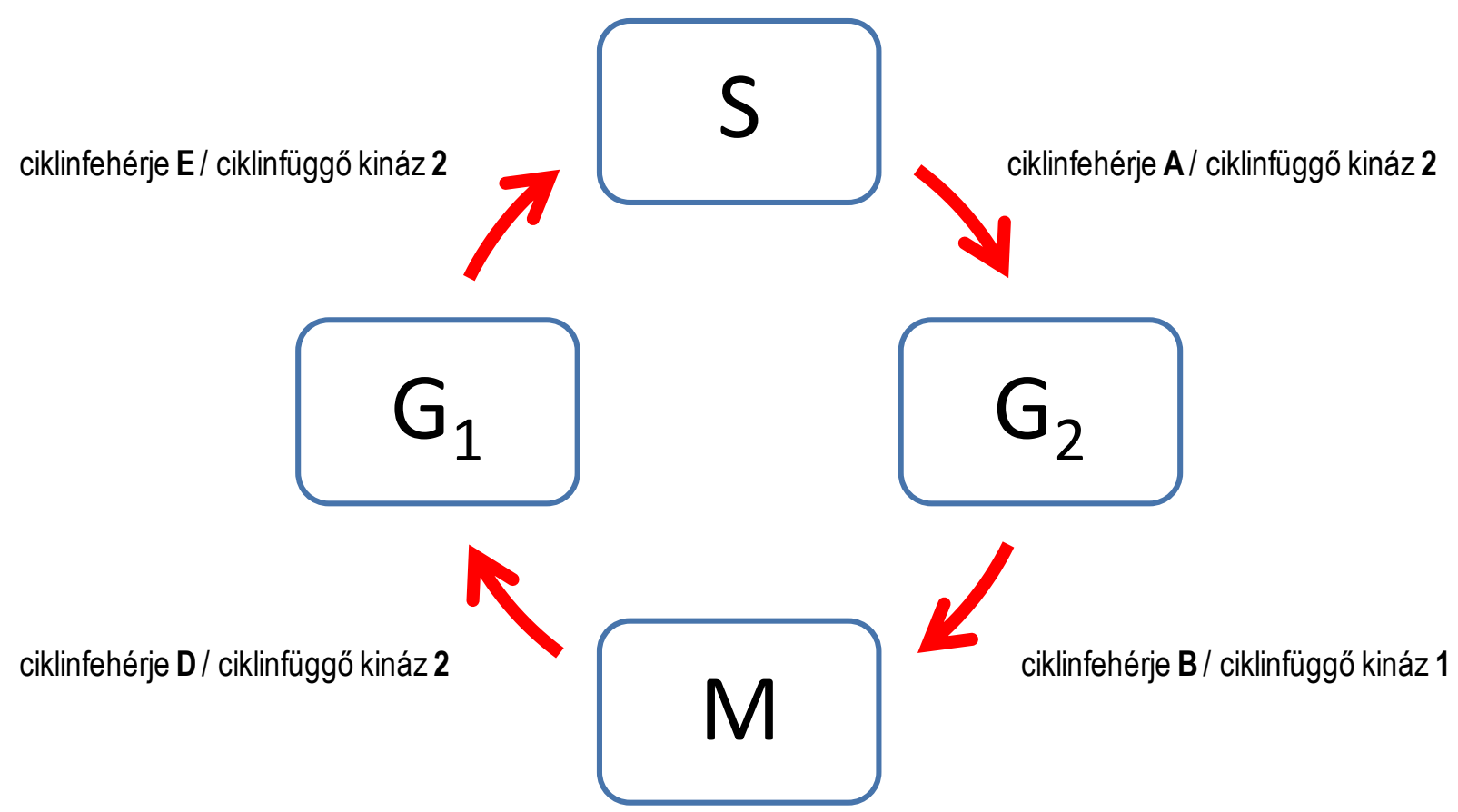

3. ábra: Ciklinfehérjék és ciklinfüggő kináz komplexek hatásának helye a sejtciklus folyamatának szabályozásában (Cell Cycle Regulation, 2013 alapján: TREERNÉ)

A gibberellinsav szintén kiváltja az S-fázis-specifikus markerek, mint például hiszton gének kifejeződését [HORVATH et al., 2002; SAUTER, 1997]. A sárkutyatej (Euphorbia esula L.) földalatti rügyeiben és az Arabidopsis L. csírázó magjaiban a gibberellinsav fokozza a G1-S fázis átmenetben részt vevő gének kifejeződését, de nem hat a G2-M fázis átmenetében részt vevő génekre a nyugalmi állapot megtörésekor [HORVATH et al., 2002; OGAWA et al., 2003]. Az auxin, citokinin és gibberellinsav növényi hormonok mind részt vesznek a sejtciklus fázis-átmeneteinek szabályozásában szerepet játszó CYCB (ciklinfehérje B) és a CDKB (ciklinfüggő kináz B) kifejeződésben és/vagy stabilitásban (3. ábra) [FrANCIS és SORRELL, 2001].

A látszólagos nyugalmi állapottal szemben az engodén nyugalmi állapot molekuláris szintű feltárása még igen hiányos. Az endogén nyugalmi állapot molekuláris biológiáját nyár (Populus deltoides L.), szőlő (Vitis vinifera L.) és burgonya esetében tanulmányozták. A nyárfában és szőlőben a külső környezeti hatások az ágak hónalj- vagy csúcsrügyeiben változásokat indukálnak és gátolják a növekedést még azután is, hogy visszatérnek a kedvező környezeti feltételek, és a korrelatív inhibitorok ismert forrásai alól felszabadulnak [HORVATH et al., 2003].

Az abszcizinsav növényi hormon szerepe régóta ismert, mint a hideg- és szárazság stressz legfontosabb jelzője [GiLmour és Thomashow, 1991]. Vélhetően ez a hormon részt vesz a ciklinfüggő kinázokat gátló fehérjék (ICK1-ek) szabályozásában, ezért elképzelhető egy olyan modell, ahol a hideg- vagy szárazság hatására felhalmozódó abszcizinsav azáltal gátolja a további növekedést és fejlődést, hogy beindítja az ICK1-termelődést a rügyekben végbemenő sejtosztódás megakadályozására [HORVATH et al., 2003]. 
A legújabb kutatások rávilágítanak arra, hogy a különböző környezeti hatásokra és fiziológiai állapotokra adott válaszok egymással kölcsönhatásban lévő hormonok hatásának eredményei a növényekben. Az etilén és a fitokróm rendszer jelentős szerepet játszik az endogén nyugalom kialakításában, az auxin pedig elsősorban a látszólagos nyugalmi állapot fenntartásáért felel. Az abszcizinsav, a gibberellinsavak és a citokininek jelentős, de antagonisztikus szerepeket játszanak mindhárom típusú nyugalmi állapot esetében. Az abszcizinsavnak, a gibberellinsavaknak és a citokinineknek mind pontosan meghatározott hatásuk van a sejtciklus folyamatát vezérlő genetikai szabályozó rendszer elemeire [HORVATH et al., 2003].

\subsection{Vágott virágok és vágott zöldek hosszabb távú tartósításának lehetőségei}

\subsubsection{Növényi anyagok tartósítása}

Sokféle vágott virág és úgynevezett különleges vágott virág (lombbal, terméssel, a vessző színével vagy formájával, stb. díszítő, általában fás szárú termék) tartósítható hosszabb távra különböző eljárásokkal. Általános tartósítási eljárások a szárítás, deszikkáns anyaggal (pl. szilícium-dioxid-gél, homok, bórax) való dehidrálás, fagyasztva szárítás, bevonás polimer diszperziókkal, és általános (szisztemikus) vagy merítéses glikol kezelés [KoCH, 1995].

A legegyszerübb a vágott virágok szárítása természetes úton, melyet lógatva, fektetve, vagy támasz (tartó, drótháló) segítségével állítva végeznek [VAUGHAN, 1998; HILLIER, 1991; WENSZKY, 1990]. A deszikkánsokkal végzett szárítás előnye a levegőn való szárításhoz képest, hogy a növények jobban megőrzik eredeti színüket, mivel ez a módszer kevésbé időigényes. A nedvesség növényi szövetekből történő kivonására többféle szárítóanyag használható. A szilikagél (szilícium-dioxid) a legköltségesebb, egyben leghatékonyabb deszikkáns, mely ismételten felhasználható. Kereskedelmi forgalomban kapható fehér kristályos anyag, illetve indikátorként viselkedő (kék kobaltsóval színezett) változata is ismert, melynél a kék színủ száraz kristályok vízfelvétel hatására rózsaszínüvé válnak. Az anyagot a szemcsenagyság csökkentése végett mozsárban összetörve célszerü használni. Légmentesen zárható edényben vagy üvegben a virágokat és a szilikagélt rétegesen lerakva két-három nap alatt kellő mértékben kiszáríthatóak a növények [HILLIER, 1991; VAUGHAN, 1998; WENSZKY, 1990]. A bórax és timsó sűrüsége kisebb, ezért jobban alkalmazhatók olyan érzékeny virágok esetében, mint az Anemone, melyet összetörne egy nehezebb deszikkáns anyag. A legjobb hatás érdekében célszerű ezeket egyenlő arányban finomszemcséjü homokkal keverni. A bórax vagy timsó alkalmazásával végzett szárítás 2-10 napot vesz igénybe [Vaughan, 1998; Hillier, 1991]. A tiszta (élő anyagtól és tengeri sótól mentes) homok is használható szárításra. Nehezebb, és tovább tart vele a szárítás, de kifejezetten 
alkalmas dália és bazsarózsa virágok szárítására, melyek sziromlevelei összegyürődnek más, könnyebb deszikkáns használatával. A homokkal való szárítás ideje néhány naptól akár négy hétig is tarthat. Új, és az összes között leggyorsabb eljárás a mikrohullámok segítségével történő szárítás. A kezelés rövidségének köszönhetően az így készített száraz virágok színe megközelíti a frissekét. A virágok előmelegített szilikagélbe ágyazva mikrohullámú sütőben néhány perc alatt kiszáríthatók [VAUGHAN, 1998].

Fagyasztva szárítás esetén a nedvességet vákuumos fagyasztásos eljárással vonják ki a virágokból. A kezelés néhány napot vesz igénybe a szárítandó fajtól és a fagyasztva szárító gép méretétől függően. Előnye, hogy a kezelt növény szerkezete, mérete és színe szinte változatlan marad. Az eljárás hátránya az áru tartósságának rövidsége. A kezelt növények a levegőből felveszik a nedvességet, meglágyulnak és kifakulnak. Jelentős a moly-kártétel is [VAUGHAN, 1998].

A Magyarországon jellemző meleg és száraz nyarak kiválóan alkalmasak a virágok vagy más növényi részek napon való szárítására és fehérítésére. A klasszikus értelemben vett szárazvirágok azonban Nyugat-Európában kimentek a divatból, helyettük egyéb növényi részeket, például szárított és festett terméseket, gyökereket, leveleket, különleges vágott virágokat, kéregdarabokat részesítenek előnyben a felhasználók. A hagyományos szárazvirágoknak Magyarországon, illetve Kelet-Európában van még némi piaca [TREERNÉ, 2006].

\subsubsection{Tartósítás glikolokkal}

A növényi részek glikolos tartósítása nem újszerü dolog, már 1919-ben használták a glicerint ilyen célra, KOROPP és társa az eljárást le is védette az Amerikai Egyesült Államokban (U.S. Patent No. 1,484,656). Az így tartósított növényi anyagok sokkal valóságosabbnak, már-már élőnek tünnek, szemben a münövényekkel. Múzeumokban évtizedek óta alkalmazzák, azonban a szárazvirágok, illetve vágott zöldek és virágok piacán csak az 1990-es években kezdett igazán népszerüvé válni ez a tartósítási eljárás [КOCH, 1995].

A glikolok a többi szárításos tartósító technikával szemben nem eltávolítják a növény víztartalmát, hanem kicserélik, helyettesítik azt [VAUGHAN, 1998]. Azáltal, hogy a növény szöveteiben a vizet nem illékony, minimálisan párolgó folyadékkal helyettesítjük, a növény sejtjeiben a folyadéktartalom sokáig magas marad a kezelést követően. Ettől hajlékony, rugalmas, értékes marad az áru [KAREL, 1973; KOCH, 1995]. Magas forráspontjuk miatt a glikolok szobahőmérsékleten nem párolognak, így megőrzik a növény folyadéktartalmát. A glikolos tartósító eljárás nagyon hatékony, de nem alkalmazható minden növénynél. Csak a glikolok megtartásához elegendő rosttal rendelkező növények reagálnak jól egy ilyen kezelésre. Ezek a rostok általában a sejtfalakban cellulóz vagy lignin formájában vannak jelen [KoCH, 1995]. A glikolos kezelés időtartama lágyszárúak esetén 3-6 nap, fás szárúaknál hat hét is lehet [VAUGHAN, 1998]. 
A glicerines kezelés hatására megváltozhat a növény színe, ami elönyös lehet, amennyiben szép őszi lombszín kialakítása a cél valamely vágott zöld esetében [VAUGHAN, 1998]. Hazánkban a Magyar Szárazvirág Kft. lajosmizsei telephelyén a Finnországból vásárolt, száraz tömbökben érkező izlandi zuzmót vízben oldódó festékkel és glicerinnel együtt kezelik, így az a kívánt színü, puha és rugalmas lesz [TREERNÉ, 2006].

\subsubsection{Növényi anyagok tartósítására használt föbb glikolok}

Glikolvegyületeket sokféle célra alkalmaznak. Fizikai tulajdonságaik ideálissá teszik őket a növényekben lévő víz helyettesítésére. Kémiailag a glikolok módosult alkoholok, melyek kettő vagy több hidroxil- (-OH) csoportot tartalmaznak, hidrofilek. A hidroxilcsoport, mint a legtöbb egyszerü funkciós csoport pozitív konjugációs hatással rendelkezik, melynek következtében a nemkötő elektronpárral rendelkező atom a szénváz felé elektront küld, ezért rajta elektronhiány, a szénvázban elektronfelesleg keletkezik, a molekulák hidrogénkötéseket hoznak létre egymással [KOSÁRY, 1999; ZUMDAHL, 1989]. A szénatomokhoz kapcsolódó hidroxilcsoportok járulnak hozzá ahhoz, hogy a glikolok forráspontja viszonylag magas [MORRISON és BOYD, 1959]. A glikolok viszkozitása magas, illékonysága alacsony, vagyis adott hőmérsékleten jóval lassabb ütemben párolognak, mint a víz [CHANG, 1984]. A viszkozitás csökken a hőmérséklet növekedésével, aminek nagy jelentősége van a növények tartósításában.<smiles>OCC(O)CO</smiles>

glicerin<smiles>[R]C(=O)O[C@H](O)[C@H]([2H])O</smiles>

monoacil-glicerin<smiles>[R]C(=O)OC([2H])C([2H])O</smiles>

diacil-glicerin<smiles>[R]C(=O)OC([2H])C([2H])OC([R])=O</smiles>

triacil-glicerin

4. ábra: A glicerin és néhány származékának kémiai szerkezete (forrás: CSAPÓ és CSAPÓNÉ, 2002)

A glicerin a növényi anyagok tartósítására legszélesebb körben alkalmazott glikol (4. ábra). Az etilén-glikolt, a dietilén-glikolt és a propilén-glikolt ritkábban használják, és néha glicerinnel keverik. A polietilén-glikolokat (PEG-eket) alkalmanként használják merítéses eljárások során glicerinnel együtt. Néhány egyéb glikollal is végeztek kísérleteket, de gyenge vagy ellentmondásos eredményekre jutottak [KoCH, 1995]. Az M7. számú mellékletben (152. o.) található lista azokat a fás szárú, zárvatermő növényeket tartalmazza, melyekkel végeztek glikolos tartósítást [KoCH, 1995; GodwIN, 1986; MAGULLION, 1977].

Glicerin (5. ábra)

- IUPAC név: Propane-1,2,3-triol 
- További elnevezések: glicerol; propán-1,2,3-triol; 1,2,3-propántriol; 1,2,3-trihidroxipropán; zsírédeny (régi magyar neve)

- Kémiai képlet: $\mathrm{C}_{3} \mathrm{H}_{5}(\mathrm{OH})_{3}$

- CAS (Chemical Abstract Services) regisztrációs szám: 56-81-5

- Moláris tömeg: 92,09382 g/mol

- Sürüség: $1,261 \mathrm{~g} / \mathrm{cm}^{3}$

- Olvadáspont: $18^{\circ} \mathrm{C}$

- Forráspont: $290^{\circ} \mathrm{C}$

- Viszkozitás: 1,490 Pa.s $\left(20^{\circ} \mathrm{C}\right)$

- Lobbanáspont: $176^{\circ} \mathrm{C}$

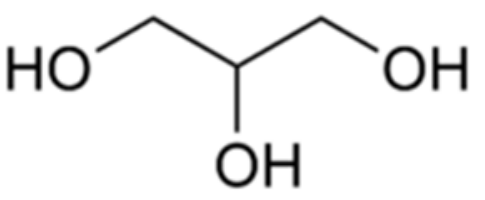

5. ábra: Glicerin (forrás: BRÜCKNER, 1961)

- Felületi feszültsége: $64 \mathrm{mN} / \mathrm{m}$

- LD50: $12600 \mathrm{mg} / \mathrm{kg}$

Amennyiben másként nem jelöltem, az adatok az anyag standard állapotára $\left(25^{\circ} \mathrm{C}, 100 \mathrm{kPa}\right)$ vonatkoznak [MORRISON és BOYD, 1959; BRÜCKNER, 1961]. A köznyelvben glicerin, helyesen glicerol. Minden élő szervezetben megtalálható, mint a gliceridek alkotórésze, melyekből glicerin képződik hidrolizálás hatására. A cukoralkoholok legegyszerübb képviselője, zsírok (összetett lipidek) elszappanosításával állítják elö. A vízmentes glicerol nedvszívó, vizes keverékeit kozmetikumokban használják [KOSÁRY, 1999]. A legtöbb tartósító oldat alapvető összetevője. Megkülönböztetünk többfélét a tisztasága, valamint az előállítás módja (természetes vagy szintetikus) alapján. A szintetikus glicerin a petrolkémiai szintézis terméke. A természetes glicerin a szappangyártás és zsírsavak előállításának egyik mellékterméke. A természetes glicerinek között megkülönböztetünk továbbá állati és növényi eredetüt. Kémiailag a glicerin minden formája ugyanúgy viselkedik és felhasználható - amennyiben megfelelő a minősége. A faggyú alapú glicerin mélyebb árnyalatú, enyhén sárgás színü, jellegzetes szagú. A kereskedelemben kapható analitikai tisztaságú termék glicerin koncentrációja 96\% és 99,7\% közötti. Nem mérgező $\left(\mathrm{OSHA}^{2}\right.$ 1910.1200.) [Glycerine, 1989 (műszaki közlöny)]. Színtelen, szagtalan, viszkózus, édeskés ízü, rendkívül széles körben alkalmazott anyag. Vízzel és etanollal korlátlanul elegyedik, de dietil-éterben, benzolban és kloroformban nem oldható. A lipidek fő alkotóeleme. A VIII. Magyar Gyógyszerkönyvben Glycerolum néven hivatalos. Élelmiszerekben a víztartalom megőrzésére, oldószerként, édesítőszerként, és zsírsavak helyettesítésére is alkalmazzák E422 néven. Cukor helyettesítésére is alkalmas, édessége a cukorénak $60 \%$-a, kalóriatartalma kevesebb. Nem emeli a vércukorszintet, és a fogszuvasodást okozó baktériumoknak nem szolgál tápanyagként. Köhögéscsillapítókban, szájvizekben, szappanokban, samponokban, fogkrémekben, krémekben

\footnotetext{
${ }^{2}$ Occupational Safety and Health Administration (Munkahelyi Biztonsági és Egészségvédelmi Ügynökség)
} 
egyaránt megtalálható, gyógynövénykivonatok esetén az etanol helyettesítésére használják [BRÜCKNER, 1961; LONG, 1917].

\section{Propilén-glikol (6. ábra)}

- Kémiai megnevezés: 1,2-Propane-triol

- További elnevezések: monopropilénglikol; 1,2 propilénglikol

- Kémiai képlet: $\mathrm{CH}_{3} \mathrm{CH}(\mathrm{OH}) \mathrm{CH}_{2} \mathrm{OH}$

- CAS (Chemical Abstract Services) regisztrációs szám: 57$55-6$

- Moláris tömeg: 76,09 g/mol

- Sürüség: $1,036 \mathrm{~g} / \mathrm{cm} 3\left(20^{\circ} \mathrm{C}\right)$

- Olvadáspont: - $59^{\circ} \mathrm{C}$

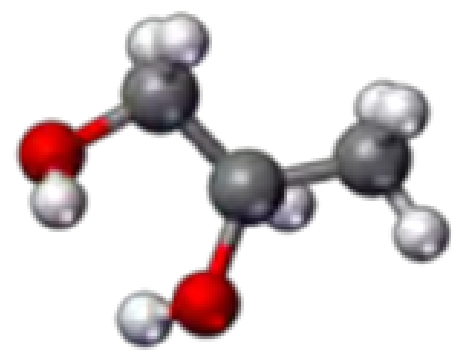

6. ábra: A propilén-glikol molekula szerkezete (forrás: Donauchem, 2013a)

- Forráspont: $188,2^{\circ} \mathrm{C}$

- Hővezető képesség: 0,34 W/m-K $\left(50 \% \mathrm{H} 2 \mathrm{O}\right.$ oldat, $\left.90^{\circ} \mathrm{C}\right)$

Enyhén édeskés ízü, színtelen folyadék. Higroszkópos, korlátlanul elegyedik vízzel, acetonnal, kloroformmal, és a legtöbb szerves oldószerrel. Számos élelmiszer, gyógyszer és kozmetikai termék összetevői közt megtalálható, továbbá kevésbé mérgező hűtőfolyadék, jégtelenítő folyadék, kenőanyag (síkosító) és fékfolyadék gyanánt is alkalmazzák. Rendelkezésre áll ipari és gyógyszerészeti minőségben is. Nem mérgező [MORRISON és BOYD, 1959; Propylene Glycol, 1990 (müszaki közlöny); KoCH, 1995; Donauchem, 2013a].

\section{Etilén-glikol (9. ábra)}

- Hivatalos neve: 1,2-etilén-diol

- További elnevezések: glikol; mono-etilénglikol; etán-1,2-diol

- Kémiai képlet: $\mathrm{C}_{2} \mathrm{H}_{4}(\mathrm{OH})_{2}$

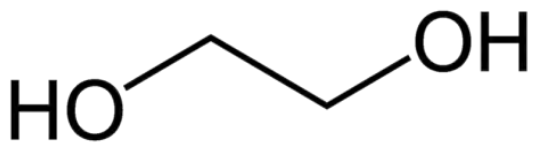

7. ábra: Etilén-glikol (forrás: ELERT, 2007)

- CAS (Chemical Abstract Services) regisztrációs szám: 107-21-1

- Moláris tömeg: 62,068 g/mol

- Olvadáspont: $-12,9^{\circ} \mathrm{C}$

- Forráspont: $197,3^{\circ} \mathrm{C}$

- Sürüség: $1,109 \mathrm{~g} / \mathrm{cm} 3\left(20^{\circ} \mathrm{C}\right) ; 1,1132 \mathrm{~g} / \mathrm{cm}^{3}\left(25^{\circ} \mathrm{C}\right)$

- Viszkozitás: $1,99 \mathrm{~Pa} \mathrm{~s}\left(20^{\circ} \mathrm{C}\right) ; 1,61 \mathrm{~Pa} \mathrm{~s}\left(25^{\circ} \mathrm{C}\right)$

- Lobbanáspont (zárt téri): $111^{\circ} \mathrm{C}$ 
Az etilén-glikol a legegyszerübb diol, a fagyálló folyadékok gyakori összetevője. Nagyobb mennyiségben mérgező, mégis gyakran borhamisításra használják, mert édes ízü, és a glicerolhoz hasonló sürüségü [KOSÁRY, 1999; КOCH, 1995; Donauchem, 2013b].

\section{Dietilénglikol (8. ábra)}

- Kémiai megnevezés: Dietilénglikol

- Kémiai képlet: $\mathrm{HOCH} 2 \mathrm{CH} 2 \mathrm{OCH} 2 \mathrm{CH} 2 \mathrm{OH}$

- Szerkezeti képlet: $\left(\mathrm{HOCH}_{2} \mathrm{CH}_{2}\right)_{2} \mathrm{O}$

- CAS (Chemical Abstract Services) regisztrációs szám: 111-46-6

- Moláris tömeg: $106,12 \mathrm{~g} / \mathrm{mol}$

- Olvadáspont: $-10,45^{\circ} \mathrm{C}$

- Forráspont: $245^{\circ} \mathrm{C}$

- Sürüség: $1,120 \mathrm{~g} / \mathrm{cm}^{3}\left(15^{\circ} \mathrm{C}\right)$

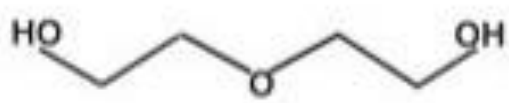

8. ábra: Dietilénglikol (Forrás: Donauchem, 2013c)
A dietilénglikol
(DEG)
szerves
vegyület,

dialkohol-éter. Színtelen, gyakorlatilag szagtalan, viszkózus, higroszkópos, édeskés ízü folyadék, jól oldódik vízben, alkoholban, éterben, acetonban és (mono)etilénglikolban. Széleskörűen alkalmazzák oldószerként, jól oldja a nitrocellulózt, mügyantákat, színezékeket, olajokat és egyéb szerves vegyületeket. Növények tartósításához szisztemikus eljárásban alkalmazzák néha magas forráspontja és alacsony illékonysága miatt. Olcsóbb a glicerinnél, de mérgező (OSHA 1910.1200.). Lenyelése veszélyes, végzetes is lehet, vese- és idegrendszeri károsodást okozhat. Emiatt virágkötészeti termékek tartósítására kevésbé ajánlott [KoCH, 1995; Donauchem, 2013c].

\subsubsection{A szisztemikus és a merítéses tartósító eljárások}

A glikollal való kezelésnek kétféle módját alkalmazzák. Az egyik az úgynevezett szisztemikus vagy általános felszívatás, melynél a növény transzspiráció útján veszi fel a glikolt. A másik módszer a merítéses kezelés, mikor a glikol a növény felszínén keresztül hatol be abba diffúzióval, mialatt az átitatni kívánt anyagot víz-glikol oldatba merítik [KOCH, 1995]. HILLIER (1991) a hosszú szárú növények kezelését felszívatással, a levelekét (pl. Magnolia, Quercus, Aspidistra) merítéses eljárással javasolja. Felszívatással tartósítható az Eucalyptus, Gypsophila, Lepidium, és Sinuata statice. Merítéssel tartósítható a Limonium tatarica, a bőrpáfrány, mohák, füfélék, levelek, és számos, előzőleg levegőn szárított növényi anyag. Nem mindig könnyü eldönteni, a kétféle eljárás közül melyiket célszerü alkalmazni. Egyértelmủ a választás, ha egy növény csak az egyik kezelésre reagál jól. Ugyanakkor van néhány növény, melyet felszívatással, és merítéssel is lehet tartósítani. A német sóvirágot (Limonium tatarica) általában merítéses eljárással szokták, de felszívatással is lehet tartósítani [KoCH, 1995]. 


\section{A merítéses eljárás előnyei}

A felszívatáshoz képest rövidebb a kezelés ideje. Az eljárást nem befolyásolják külső tényezök, mint a hőmérséklet, páratartalom. Számos friss és szárított növény tartósitására alkalmas. A kezelés általában eliminálja a növényen esetleg jelenlévő rovarokat és lárvákat, ezáltal csökkentve a gázosítás szükségességét. Számos faj, mellyel nem lehetséges a szisztemikus kezelést megvalósítani, igen jól reagál a merítéses módszerre (pl. Magnolia levelek). A tartósító oldathoz festéket adva teljes színfedést lehet elérni. Üzemi méretekben is alkalmazható, könnyen gépesíthetö [KoCH, 1995].

\section{A merítéses eljárás hátrányai}

Roncsolja a növény kutikuláját, így az már nem tud megfelelő válaszfalként müködni a szervezeten belüli glikol és az azt körülvevő pára találkozásának megakadályozására. Az eljárás általában melegítést igényel. Festék alkalmazásakor nem mindig kívánatos a teljes színfedés. Az így kezelt termékek tapintásra olajosnak tünhetnek. Sok érzékeny virágot (pl. fátyolvirág) nem lehet merítéssel tartósítani anélkül, hogy a virág természetes megjelenésén ne essék jelentős csorba [KoCH, 1995].

\section{A szisztemikus tartósitás (felszívatás) előnyei}

A növény kutikulája ép marad. Egy szisztemikusan tartósított növény jobban hasonlít eredeti természetes önmagára, mint egy merítéses eljárással kezelt. A felszívatással tartósított növényeknél kevésbé lép fel a könnyezés jelensége. Számos érzékeny, finom szerkezetủ virág (pl. Lepidium, Gypsophila) nem kezelhető merítéssel, ezeket csak felszívatással lehet tartósítani [КосH, 1995].

\section{A szisztemikus tartósítás hátrányai}

A növények betakarítása után hamar el kell kezdeni a kezelést. A felszívatásos eljárást nagymértékben befolyásolják külső környezeti tényezők (pl. hőmérséklet, páratartalom). Rendszerint hosszadalmas, és kevésbé alkalmazható nagyüzemi méretekben [КоCH, 1995].

\subsubsection{Glikolok kiválása a tartósított növényi anyagokból}

A tartósított virágok és levélzet esetében problémaként jelentkezhet a többlet glikol megjelenése a növények felületén. Ezt angolul izzadásnak, vérzésnek vagy könnyezésnek nevezik, és néhány tartósított termék esetén jelentős problémát okozhat. A könnyezés jelensége a glikolok erősen hidrofil tulajdonságából fakad. A glicerin kiválása a tartósított növényi részből elsősorban a levegő magas relatív páratartalma esetén jelentkezik. A növényben lévő glicerin vizet abszorbeál a levegőből, ami a glicerin-víz oldat viszkozitásának csökkenését eredményezi. A glicerin 
akár 20\%-os relatív páratartalom esetén is képes vizet megkötni a levegőből. A tartósított növényben lévő glicerin-víz oldat viszkozitása csökken, ahogy mind több víz abszorbeálódik. A léghömérséklet növekedésével is csökken a viszkozitás. Ennek következtében az oldat könnyen áramlik a növényen belül. Átáramlik a sejtközötti járatokon, végül egy része eljut a növény felületéig. Magas páratartalom esetén a könnyezés olyan súlyos lehet, hogy a glicerin oldat csepeg a növényről [KOCH, 1995]. VAUGHAN (1998) ezzel szemben a levelek glicerin-víz eleggyel történő kenegetését is javasolja, és akkor tekinti befejezettnek a tartósító kezelést, amikor a glicerin apró cseppek formájában kivált a növény felületén. Az Eucalyptus és Gypsophila fajoknál, valamint egyes páfrányok és pálmaágak kezelésénél általános a könnyezés, mely különösen a glicerin alkalmazása során jelentkezik. Ezért néhány gyártó a propilén-glikolt vagy az etilén-glikolt választja inkább a tartósító oldat aktív összetevőjéül [KoCH, 1995].

\subsubsection{A tartósító oldat összetevőii}

A tartósító oldat rendszerint a következö összetevőket tartalmazza: glikol-víz keverék, kémhatást beállító anyag, fertőtlenítőszer, nedvesítő- és színanyag. Nedvesítő anyag hozzáadásával a folyadék felületi feszültsége csökkenthető, így könnyebb a tartósító oldat felvétele, és jobb minőségü lesz a tartósított növényi anyag [KoCH, 1995]. Az alkalmazott nedvesítő anyagok között jelentős különbségek tapasztalhatók, legalkalmasabb a Tween $20^{\mathrm{TM}}$ és a Tween $80^{\mathrm{TM}}$, melyek a többi nedvesítő anyagnál kevésbé fitotoxikusak [ARMITAGE, 1993].

\section{Glikol-víz keverék}

Mindkét eljárás alkalmazásakor elengedhetetlen a glikolok vízzel való higítása. A tiszta glikolokat azok magas viszkozitásánál fogva sem transzspiráció, sem diffúzió által nem tudják felvenni a növények. A glikol koncentrációját többféleképpen lehet beállítani a glikol-víz keverékben. A százalékot súlyra vagy térfogatra vonatkoztatják, gyakran arányokban adják meg (például 3 rész víz, 1 rész glicerin). A felszívatásos eljáráshoz alkalmazott glikol oldatok tipikusan 10-39 tömegszázalék (8-33 térfogatszázalék) glikolt tartalmaznak. A merítéses eljárás során használt oldatok esetében valamivel magasabb a glikol aránya, ezek az oldatok általában 12-56 tömegszázalékosak. A növények tartósítására leggyakrabban alkalmazott glikol a glicerin, de miután (1994-ben) az Amerikai Egyesült Államokban nagyon felment az ára, sok gyártó áttért etilén-glikolra és propilén-glikolra. Ez utóbbiak azonban kevésbé alkalmasak növények tartósítására magasabb illékonyságuk és alacsonyabb forráspontjuk miatt. Az etilén-glikol használata mérgező volta miatt is ellenjavallt. A költségek csökkentése érdekében néhányan glicerin és más glikolok keverékét alkalmazzák [KOCH, 1995]. HILLIER (1991) szisztemikus tartósításra 40\% glicerinből és $60 \%$ forró vízből készített oldatot, a merítéses eljáráshoz ennél töményebb, 50\%- 
os oldatot ajánl. VAUGHAN (1998) 1 rész glicerin és 2 rész forró víz keverékét javasolja, mely 10 cm mélyen lepi el a növények szárát.

\section{A felszívató oldat kémhatása}

A friss vágott virágok a savas kémhatású oldatokat lényegesen könnyebben tudják felvenni, mint a lúgosakat [SACALIS, 1988]. EvANS és REED (1990) kísérletében a pH 3,2-3,5 közötti kémhatású folyadékot vették fel leghatékonyabban a vágott virágok. Egy glikolos tartósításról szóló ausztrál tanulmányban megállapították, hogy egy viszonylag széles $\mathrm{pH}$ tartományban nincs jelentős növekedés az oldat felvételében [DUBOIS és JOYCE, 1992]. A kémhatás csökkentése elsősorban azért ajánlott, mert a káros mikroorganizmusok (baktériumok, penészek és más gombák) szaporodása lassabb vagy gátolt savas közegben [RAVEN et al., 1986; KoCH, 1995]. Leggyakrabban citromsav hozzáadásával csökkentik a tartósító oldat kémhatását [EvANS és REED, 1990]. Szükséges mennyisége a helyi vízminőségtől függ. Érdemes 400 ppm mennyiséggel kezdeni, és azt szükség szerint változtatni [KoCH, 1995]. Alkalmazzák még az izo-aszkorbinsavat, a borkősavat és a benzolsavat [NOWAK és RUDNICKI, 1990].

\section{Fertőzések megakadályozása}

Jelentős mennyiségü hulladék keletkezik, amikor a tartósító oldatot a benne megjelenő mikrobák miatt már nem lehet hatékonyan felhasználni. A mikrobák megjelenése akadályozza az oldat felvételét, a baktériumok eltömíthetik a növények szállítóedény-nyalábjait, illetve etilént és toxint termelhetnek, mely a tartósított anyag öregedését idézheti elő. A tartósító oldatok fertőtlenítésére a következő szereket alkalmazzák: 8-HQC (8-hidroxikinolin-citrát: 200-600 ppm), kálium-szorbát citromsavval, nátrium-benzoát citromsavval, nátrium-hipoklorit, ammónium-klorid, alumínium-szulfát (200-300 ppm) [KoCH, 1995; NOWAK és RUDNICKI, 1990].

\subsubsection{A víz-helyettesítési faktor (Z) meghatározása}

A növények tartósításához szükséges glikol-mennyiség meghatározása összetett feladat. Minden növény máshogy reagál erre a fajta tartósításra, és így egyedileg kell értékelni. Glikolos tartósítás esetén meg kell határozni, hogy az adott növény víztartalmának mekkora arányát kell glicerinnel vagy más glikolok kombinációjával helyettesíteni. A víz helyettesítés mértékének meghatározásához КоCH (1995) kézikönyvében egy újfajta mennyiségi mértéket definiál, az úgynevezett „víz-helyettesítési faktor”-t, melyet Z-vel jelöl. A szerző ezt a Z értéket úgy határozza meg, mint a növényben lévő, glikollal helyettesítendő víztartalom tömegszázalékát. A szerző szerint akkor beszélhetünk hatékony glikolos tartósításról, ha a növény friss víz tartalmának 40-50\%-a glikolra, elsősorban glicerinre cserélődik. A Z-értékek széles skálán mozoghatnak. A túl sok glicerin hátrányos is lehet, és gyakran a kiválás problémájához vezet. A Z-érték meg- 
határozásához az ismert súlyú növény által felvett glicerin mennyiségét kell elosztani az adott növényben eredetileg lévő összes vízmennyiséggel. A növények víztartalma is széles skálán mozog, a lágyszárúaké általában magasabb a fás szárúakéhoz képest, és a növényen belül is változó. A leveleknek magasabb a víztartalma, mint a szárnak, illetve az ágaknak, ahol a rosttartalom magasabb a növény szerkezetéből adódóan. A szerző azt tapasztalta, hogy az 50-75\% közötti víztartalmú növények reagálnak jól a glikolos tartósitásra, feltéve, hogy ennek eloszlása nagyjából állandó az egész növényben [KOCH, 1995]. A növények víztartalma 65-91\% közötti, mely szabad és kötött formában van jelen a sejtekben és sejt közötti járatokban. A szabad víz nagy részét le tudja adni a növény, de a sejtek szerkezetében kötött vizet csak magas hőfokú száritással lehet belöle kivonni [SZALAI, 2001].

A helyes Z-érték ismeretében lehet megállapítani egy adott növény megfelelö tartósításához szükséges glicerin mennyiségét. A helyesen tartósított növényt minőségi (kvalitatív), és mennyiségi (kvantitatív) paraméterek jellemzik. Minőségi tulajdonság a lombozat (vágott zöld esetén), vagy a virágos vesszők vizuális megjelenése, tapintása, könnyü felhasználhatósága, stb. A mennyiségi követelmények olyan számszerüsíthető méréseken alapulnak, mint például törésellenállás bizonyos behatásokra; szár törési szög, könnyezési próbára adott reakció, stb. [KoCH, 1995]. 


\section{ANYAG ÉS MÓDSZER}

Munkám során az alábbi összefoglaló táblázatban szereplő klónokat vizsgáltam részletesebben, velük végeztem a következő fejezetekben részletezett módszerekkel különböző kísérleteimet (2. táblázat). Ezeken túl a barkafüzek termesztésével és a barkás füzvesszők hazai kínálatával kapcsolatban $S$. caprea, S. purpurea, S. rosmarinifolia, S. cinerea, S. viminalis, és $S$. x smithiana fajokat és hibrideket vizsgáltam, a táblázatban felsorolt klónok mellett ezeken figyeltem meg további károsítókat és más minőségrontó tényezőket is.

2. táblázat: A kísérletekben szereplő taxonok, beszerzésük és szaporításuk helye és ideje, valamint a velük elvégzett megfigyelések, vizsgálatok és kísérletek összegzése

\begin{tabular}{|c|c|c|c|c|c|c|c|c|c|c|}
\hline \multirow[b]{2}{*}{ 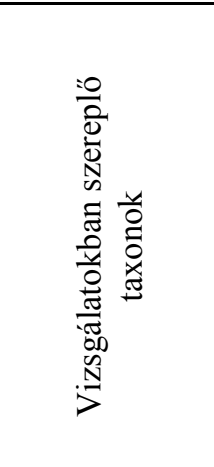 } & \multicolumn{2}{|c|}{ Vesszők beszerzésének } & \multicolumn{2}{|l|}{ Szaporítás } & \multicolumn{6}{|c|}{ Elvégzett vizsgálatok, kísérletek } \\
\hline & helye & ideje & módja & ideje & 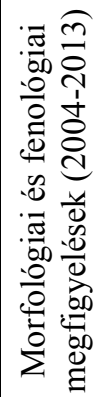 & 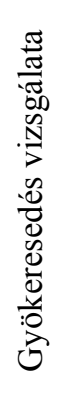 & 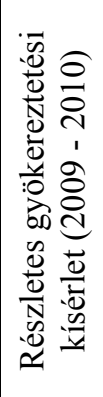 & 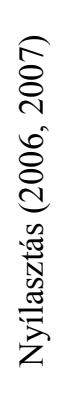 & 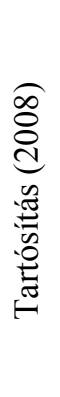 & 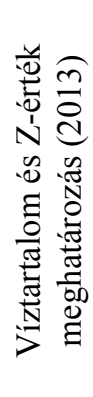 \\
\hline $\begin{array}{l}\text { Salix caprea } \\
\text { CA1 }\end{array}$ & $\begin{array}{l}\text { Flora Hunga- } \\
\text { ria, Sziget- } \\
\text { szentmiklós }\end{array}$ & $\begin{array}{l}2004 . \\
03.22\end{array}$ & $\begin{array}{c}\text { Szabadföldi fás- } \\
\text { dugványozás So- } \\
\text { roksáron }\end{array}$ & $\begin{array}{l}2004, \\
2006, \\
2007\end{array}$ & - & - & - & - & $\bullet$ & - \\
\hline $\begin{array}{l}\text { Salix } \\
\text { purpurea PU1 }\end{array}$ & $\begin{array}{l}\text { Flora Hunga- } \\
\text { ria, Sziget- } \\
\text { szentmiklós } \\
\end{array}$ & $\begin{array}{l}2004 . \\
03.01\end{array}$ & $\begin{array}{l}\text { Szabadföldi fás- } \\
\text { dugványozás So- } \\
\text { roksáron }\end{array}$ & $\begin{array}{l}2004, \\
2006, \\
2007\end{array}$ & • & - & & - & & \\
\hline $\begin{array}{l}\text { Salix } \\
\text { purpurea PU2 }\end{array}$ & $\begin{array}{l}\text { Flora Hunga- } \\
\text { ria, Sziget- } \\
\text { szentmiklós }\end{array}$ & $\begin{array}{l}2004 . \\
03.22\end{array}$ & $\begin{array}{l}\text { Szabadföldi fás- } \\
\text { dugványozás So- } \\
\text { roksáron }\end{array}$ & $\begin{array}{l}2004, \\
2006, \\
2007\end{array}$ & - & - & & - & - & \\
\hline $\begin{array}{l}\text { Salix } \\
\text { rosmarinifolia } \\
\text { RO1 }\end{array}$ & $\begin{array}{l}\text { Flora Hunga- } \\
\text { ria, Sziget- } \\
\text { szentmiklós }\end{array}$ & $\begin{array}{l}2004 . \\
03.22\end{array}$ & $\begin{array}{c}\text { Szabadföldi fás- } \\
\text { dugványozás So- } \\
\text { roksáron }\end{array}$ & $\begin{array}{l}2004 . \\
04.02\end{array}$ & - & - & & & - & \\
\hline $\begin{array}{l}\text { Salix } \\
\text { rosmarinifolia } \\
\text { RO2 }\end{array}$ & $\begin{array}{l}\text { Flora Hunga- } \\
\text { ria, Sziget- } \\
\text { szentmiklós }\end{array}$ & $\begin{array}{l}2004 . \\
03.22\end{array}$ & $\begin{array}{c}\text { Szabadföldi fás- } \\
\text { dugványozás So- } \\
\text { roksáron }\end{array}$ & $\begin{array}{c}2004.04 . \\
02\end{array}$ & - & - & & & & \\
\hline $\begin{array}{l}\text { Salix } \\
\text { rosmarinifolia } \\
\text { RO3 }\end{array}$ & $\begin{array}{l}\text { Flora Hunga- } \\
\text { ria, Sziget- } \\
\text { szentmiklós } \\
\end{array}$ & $\begin{array}{l}2006 . \\
\text { márc. }\end{array}$ & $\begin{array}{c}\text { Szabadföldi fás- } \\
\text { dugványozás So- } \\
\text { roksáron }\end{array}$ & $\begin{array}{l}2006 . \\
\text { április }\end{array}$ & - & - & - & & & \\
\hline $\begin{array}{l}\text { Salix } \\
\text { rosmarinifolia } \\
\text { RO4 }\end{array}$ & Szombathely & $\begin{array}{l}2008 . \\
02.08\end{array}$ & $\begin{array}{l}\text { Fásdugványozás } \\
\text { szaporítótálcában, } \\
\text { fütetlen üvegházban } \\
\text { (Soroksár) }\end{array}$ & $\begin{array}{l}2008 . \\
02.21\end{array}$ & - & - & & & & \\
\hline $\begin{array}{l}\text { Salix } \\
\text { rosmarinifolia }\end{array}$ & Felsőmizse & $\begin{array}{l}2006 . \\
02.11\end{array}$ & - & - & & & & - & & \\
\hline
\end{tabular}




\subsection{Barkás vessző termesztés céljából szelektált Salix klónok morfológiai és fenológiai vizsgálata, vesszőhozama és gyökeresedése}

A 2. táblázatban felsorolt klónok vesszőit többnyire gyüjtőktől vásároltam a szigetszentmiklósi Flora Hungaria virágpiacon. Alsó részükből fásdugványokat vágtam, ezekből anyanövényeket neveltem Soroksáron, a Budapesti Corvinus Egyetem Kertészettudományi Karának Kísérleti Üzemében. Több anyanövényről 2006. és 2007. tavaszán újabb töveket szaporítottam fásdugványozással. Az anyanövényeken, illetve a 2, 3, 4, és 6 évvel fiatalabb ültetvényekben és növényeken végeztem fenológiai és morfológiai megfigyeléseimet és vizsgálataimat.

A fenológiai megfigyeléseket közel tíz éven keresztül végeztem az általam telepített soroksári ültetvényekben, elsősorban a tavaszi és az őszi időszakban. Megfigyeltem és feljegyeztem a virágzati rügyek fejlődésének menetét a rügypikkelyek megpattanásától a teljes virágzásig. Ennek a folyamatnak rendkívül nagy jelentősége van a barkás vessző, mint áru megjelenésének, továbbá a megfelelő szedési idő megállapításának szempontjából. Figyelemmel kísértem a hajtásrügyek fakadását, a hajtások és levelek fejlődését. Összel a lombozat sárgulását, a lombhullás alakulását vizsgáltam az egyes taxonok esetében.

A morfológiai paraméterek alapján részletes leírást kívántam adni különösen azokról a klónokról, melyeket érdemes volna önálló fajtaként elismertetni, majd termeszteni és értékesíteni. Morfológiai vizsgálataim kiterjedtek a vesszők színére, méretére, növekedési jellegére, a rügyek alakjára, a rügypikkely színére és leválásának módjára, a levelek méretére, formájára, a levélszél fogazottságára, a levél színére és szőrözöttségére, a fellevelekre, valamint részletesen a füzérvirágzatokra (murvapikkelyek formája, színe, szőrözöttsége).

Mértem a különböző korú növények magasságát és átmérőjét, melyekből az ideális tenyészterületre is következtetni lehet. Minden tavasszal visszavágtam a töveket, és leszámoltam, továbbá megmértem az egyes tövekről származó vesszők mennyiségét és méretét. Ennek ismeretében lehet tervezni a növényekből származó bevételt is.

A S. rosmarinifolia RO1 és RO2 jelü klónokból a dugványozást követő évben a tövek viszszavágása után két-két növényt kiástam és nagyméretü (10 literes) konténerbe ültettem. Ezeknek a töveknek a gyökérfejlődését így figyelemmel tudtam kísérni.

A S. rosmarinifolia RO4 klónjának esetében különböző átmérőjü dugványokkal végeztem szaporítást, majd az eredményekből következtetni tudtam a dugványok átméröjének és a gyökeresedés mértékének összefüggéseire. A S. rosmarinifolia RO4 taxon vesszőit 2008. február 8-án szedtem, és hủtőtárolás után február 21-én vágtam dugványokat a vesszők tőhöz közel eső részéből. Ezeket Soroksáron az egyetem Kísérleti Üzemében, fütetlen üvegházban, szaporítótálcába, homok és perlit 8:2 arányú keverékébe dugványoztam. A $37 \mathrm{db}, 6 \mathrm{~cm}$ hosszú dugványt kezdet- 
ben üvegházban, fóliaalagút alatt tartottam. Egy hónappal később, április 7-én a dugványok becserepezésekor megmértem a dugványok átmérőjét és a gyökeresedés mértékét. A gyökeresedés és a dugványok átméröje közötti összefüggést függetlenségvizsgálattal elemeztem.

\subsection{A melegtalp kezelés, a gyökereztető szerek, és a szaporítási időpontok hatásának vizsgálata a gyökeresedésre}

S. caprea CA1 és $S$. rosmarinifolia RO3 klónok gyökeresedését vizsgáltam, melyek tapasztalataim szerint kezelés nélkül nagyon kis százalékban eredtek meg szabadföldi dugványozáskor. A háromtényezős kísérletben az alábbiak hatását vizsgáltam.

Alkalmazott kezelések (zárójelben feltüntetve a mérési jegyzökönyvekben, jeltáblákon, és fényképeken is látható, kezeléseket jelölő rövidítések):

- melegtalp, mely a növényház léghőmérsékleténél $5^{\circ} \mathrm{C}$-al magasabb hömérsékletet biztosít a dugványok talpánál (,M”)

- $~ \sim 15^{\circ} \mathrm{C}$ léghömérséklet a növényházban, melegtalp nélkül („,H”)

\section{Alkalmazott gyökereztetést serkentő szerek:}

- $\alpha$-naftil-ecetsav (NES) 6\%o-es koncentrációban 50\%-os etanolban oldva („NESo”)

- $\quad \alpha$-naftil-ecetsav (NES) 6\%o-es koncentrációban talcum poros formában („NESp”)

- $\operatorname{Kelpak}^{\circledR} 2 \%$-es koncentrációban, 30 percen keresztül végzett felszívatás („Ke1/2”)

- $\operatorname{Kelpak}^{\circledR} 2 \%$-es koncentrációban, 8 órán keresztül végzett felszívatás („Ke $\left.8 ”\right)$

- Kontroll (,C”)

Vesszők szedésének és a dugványozás időpontja (fenti szerekkel és kezelésekkel kombinálva):

- novemberi dugványozás (2009. november harmadik dekádja)

- decemberi dugványozás (2009. december harmadik dekádja)

- januári dugványozás (2010. január harmadik dekádja) 


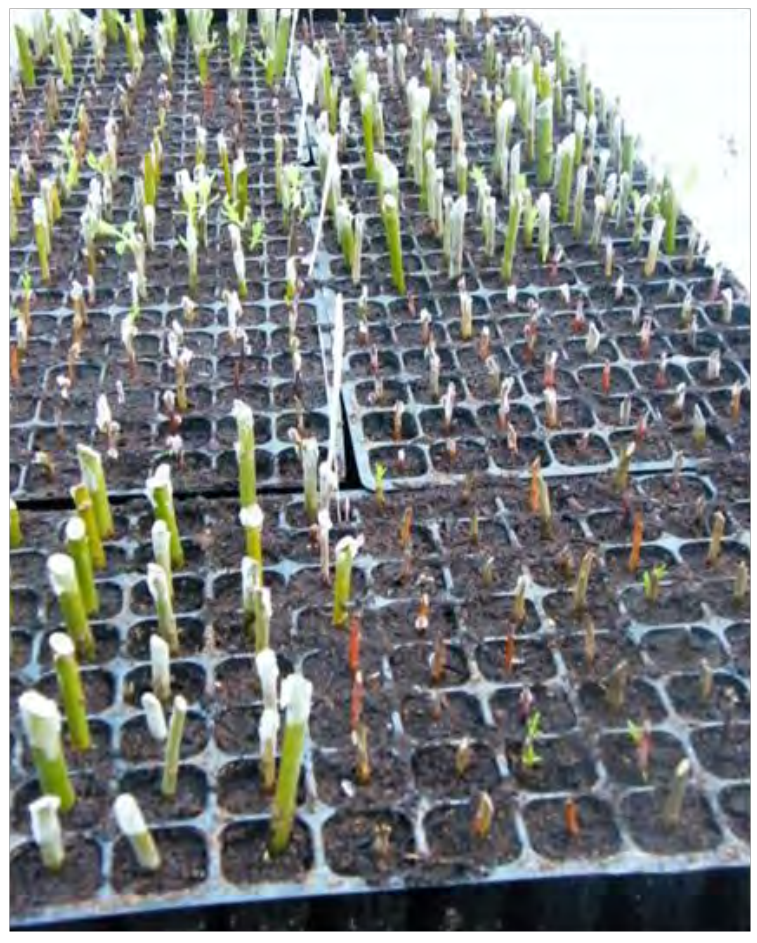

9. ábra: Gyökereztetési kísérlet melegtalpon (fotó: Treerné, 2009)

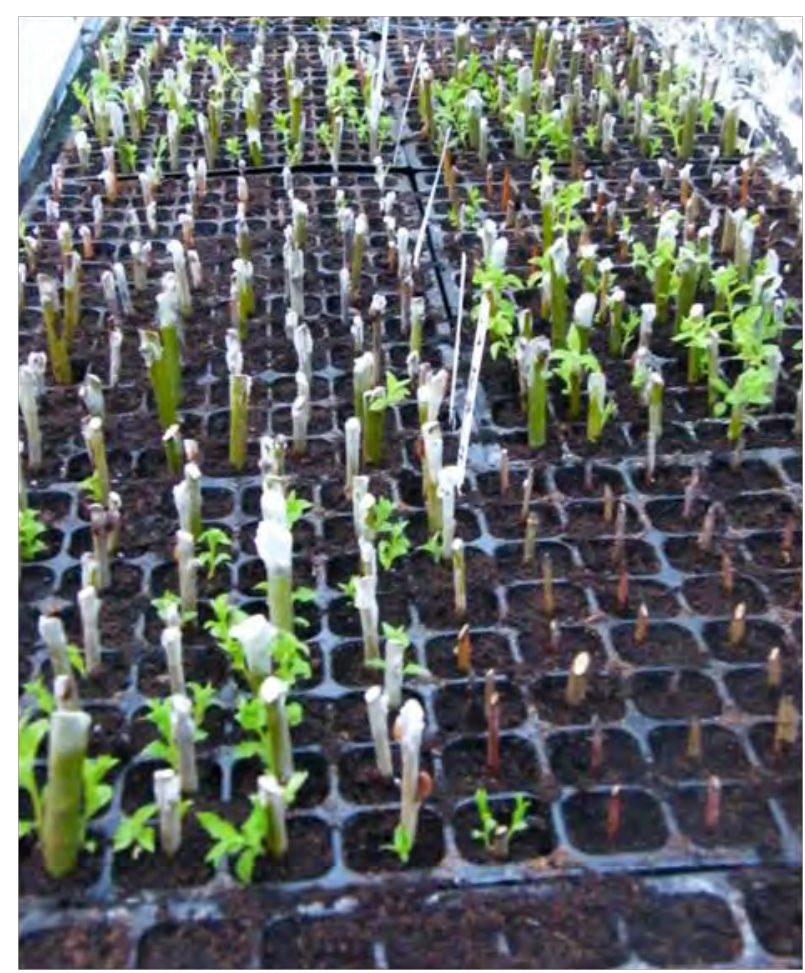

10. ábra: Gyökereztetési kísérlet melegtalp nélküli asztalon (fotó: Treerné, 2009)

A dugványokat a korábban Soroksáron szaporított anyatövekről szedtem, és helyben vágtam meg $5 \mathrm{~cm}$ (S. rosmarinifolia), illetve $8 \mathrm{~cm}(S$. caprea) hosszúságúra. A Budapesti Corvinus Egyetem, Kertészettudományi Kar, Dísznövénytermesztési és Dendrológiai Tanszékének a Budai Campuson, a Budai Arborétum Felső Kertjében álló üvegházában 2009. november és 2010. január között dugványoztam 8 x 13 rekeszű Teku sejttálcákba, magvetéshez is ajánlott közegbe (TerraCult Blue 70 literes kiszerelés: TerraCult Substrate TC1 Seedling substrate). Minden kezelést 50 dugványon végeztem, azaz kezelési időpontonként 1000-1000 dugványt vágtam meg. Ezekből 500 került melegtalpra (9. ábra), 500-at az üvegházban melegtalp nélküli asztalon (10. ábra) helyeztem el. A dugványok kiszáradása ellen azok felső végét méhviasz tartalmú BIOCERA fasebkezelő- és oltóviasszal zártam le. Ügyeltem rá, hogy a melegtalpon lévő szaporítótálcák (sejttálcák) alatti felszívatószőnyeg mindig kellően nedves legyen a megfelelő páratartalom és a hővezetés biztosításának céljából. Kezdetben az összes dugványt fátyolfóliával takartam, szintén a magasabb relatív páratartalom elérése végett, hogy a dugványok kiszáradását megelőzzem. Ezután heti rendszerességgel ellenőriztem a dugványok állapotát, a gyökeresedés módját (kalluszcsomók megjelenése; kalluszcsomók és gyökérkezdemények fejlődése; intenzív kalluszképződés gyökérfejlődés nélkül; kambiumból közvetlen gyökérképződés) és mértékét. A dugványokat szükség szerint öntöztem. A dugványozást követő heti megfigyelésekhez minden alkalommal egy újabb sor ( 8 vagy $10 \mathrm{db}$ ) dugványt húztam ki, értékeltem és fotóztam, majd óvatosan visszatettem a sejttálcába. Így nem fordulhatott elő olyan tévedés, hogy egy vizsgálat során esetleg sérült gyökerű dugványt a következő vizsgálat alkalmával hibásan minősítek, mert kezelésenként éppen annyi dugvány került a sejttálcába, hogy minden alkalommal érintetlen dug- 
ványt vizsgálhattam. A végső kiértékeléskor fajonként egy-egy bonitálási sort állítottam fel (11. ábra, 12. ábra), és ezek alapján osztályoztam a dugványokat. A viszonyítási alapot a fejlődött gyökerek mérete és mennyisége adta. A novemberben dugványozott növényanyag utolsó kiértékelését 2010. február 22-én végeztem. A következő hat kategóriát határoztam meg az alábbi bonitálási értékekkel:

- 0 : egyáltalán nem gyökeresedett

- 1: épp megjelenő, 10 mm-nél rövidebb gyökerek vagy kalluszcsomók

- 2: kevés (1-3 db) közepes (10-30 mm hosszú) ép, egészséges gyökér

- 3: 3-6 db 20 mm-nél hosszabb gyökér - gyökerekkel félig átszött földlabda

- 4: gyökerekkel teljesen átszőtt földlabda

- x: dugványról levált meggyökeresedett hajtás

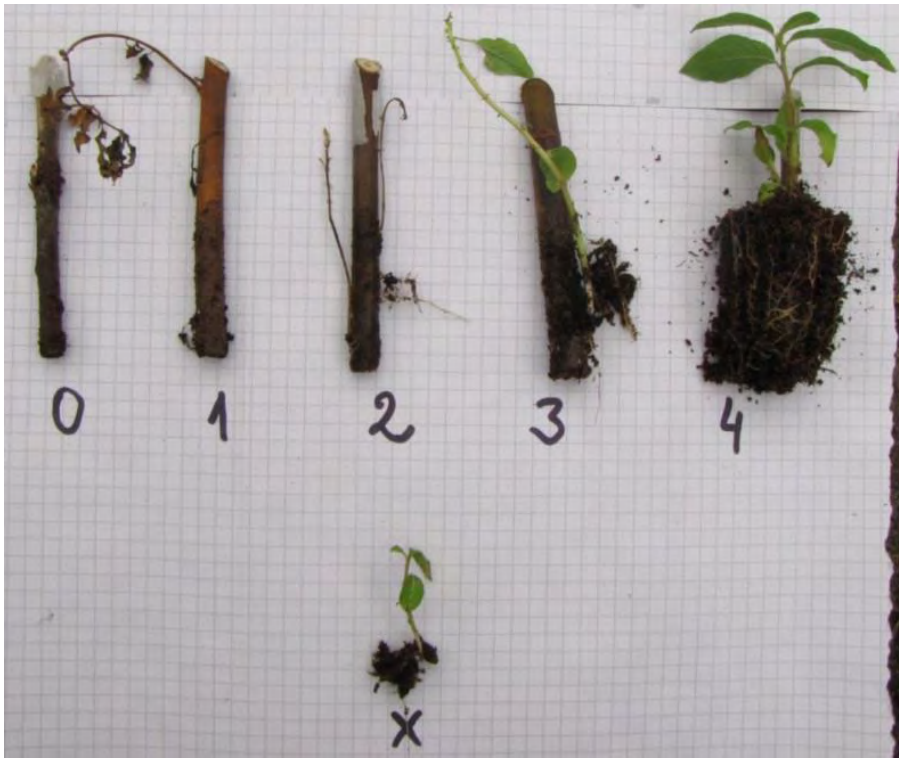

11. ábra: Bonitálási sor Salix caprea dugványok gyökereztetésének értékelésére (fotó: Treerné, 2010)

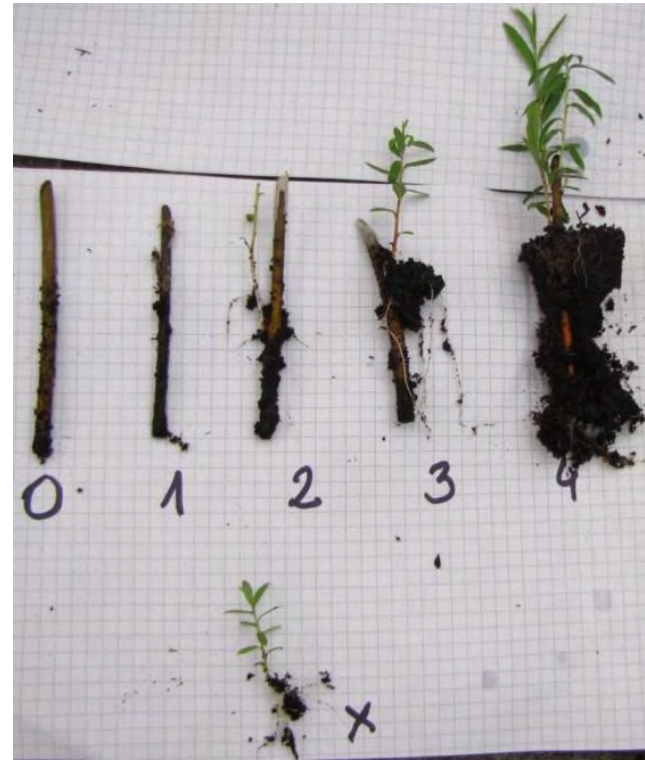

12. ábra: Bonitálási sor Salix rosmarinifolia dugványok gyökereztetésének értékelésére (fotó: Treerné, 2010)

A 2009. novemberi dugványozás eredményeit 2010. február 22-én, a 2009. decemberi dugványozásét 2010. március 19-én, a januári kísérletekét március 22-én bonitáltam.

Az értékelés során megszámoltam és megmértem a dugványokon fejlődött gyökereket, feljegyeztem a kezelésenkénti összes dugvány esetleges kihajtásának arányát és mértékét, és minden egyéb megfigyelésemet (pl. erőteljes kalluszképződés, a dugvány talpának megduzzadása, a vesszőszín változása, hajtás- vagy virágzati rügyek fakadása, kártevők megjelenése). 


\subsection{Salix fajok károsítóinak és más minőségrontó tényezőinek vizsgálata}

A Soroksári Kísérleti Üzem díszfaiskolájában telepített növényeken a fenológiai megfigyelések, valamint a morfológiai paraméterek vizsgálata közben alkalmam nyílt többféle károsító megfigyelésére. Elsősorban ezek kártételével vagy tünetével találkoztam, melyekből a károsító kilétére lehetett következtetni. Esetenként magát a kártevőt is megfigyelhettem a növényeken. Egy kevésbé könnyen meghatározható hernyóból sikerült kinevelnem a lepkét, továbbá egy gubacsdarázs lárvái is sikeresen bebábozódtak, miután leszedtem öket a növényekröl, és a Dísznövénytermesztési és Dendrológiai Tanszék laboratóriumában igyekeztem őket egy petri csészében kinevelni. Saját megfigyeléseimet a gyüjtők tapasztalatai is kiegészítették, akik esetenként felhívták a figyelmemet egy-egy károsítóra, mely az általuk szedett árun, vagy saját ültetvényeikben megjelent. Egy dabasi gyüjtőnél és termesztőnél találkoztam igen erős szövőlepke kártétellel, egy nagyméretü törzskorhasztó gombát pedig a Dunakeszi láp látogatása során volt alkalmam megfigyelni, ahová a füzek tanulmányozásának céljából látogattam el.

\subsection{Salix rosmarinifolia vesszők nyílasztásának vizsgálata}

Nyílasztási kísérletemhez a gyöngybarka vesszőket 2006. február 11-én gyüjtöttem Pest megyében, Felsőmizse északi határában, az 5-ös autóúttól nyugatra. A vesszők egy részét egyetlen nagyobb kiterjedésű, körülbelül $3 \mathrm{~m}^{2}$ területű sarjtelepről szedtem, ezeket különválogattam, a többit további három sarjtelepről gyüjtöttem be. A sarjtelepek egy 80 méter átmérőjü körön belül helyezkedtek el. Kétféle nyílasztó oldatot alkalmaztam, kontrollként vízbe állítottam a vesszőket. Az egyes nyílasztó oldatokba olyan mennyiségü gibberellint mértem, hogy a nagyobb koncentrációjúban a kisebbhez képest négyszeres mennyiségü legyen. Ezen túl a mikroorganizmusok elszaporodásának megelőzésére 8-hidrokinolin-szulfátot (8HQS), valamint energiaforrásként répacukrot adtam az oldathoz. A kémhatást $(\mathrm{pH}=4,4)$ az 1 . oldat esetén citromsavval állítottam be, a 2. oldatnál erre nem volt szükség. Az oldatok összetétele a következő volt:
1. nyílasztó oldat (1,5\% $\left.\mathrm{GA}_{3}\right)$ :
2. nyílasztó oldat (6\% GA $\left.\mathrm{GA}_{3}\right)$
- 8-hidrokinolin-szulfát (8HQS): $0,4 \mathrm{~g} / 1$
- 8-hidrokinolin-szulfát (8HQS): $0,4 \mathrm{~g} / 1$
- Szacharóz (répacukor): $20 \mathrm{~g} / 1$
- Gibberellinsav $\left(\mathrm{GA}_{3}\right): 1,5 \mathrm{~g} / 1$
- Szacharóz (répacukor): $20 \mathrm{~g} / 1$
- Citromsav: 0,73 g/l
- Gibberellinsav $\left(\mathrm{GA}_{3}\right): 6 \mathrm{~g} / 1$

Az oldatokat a vesszők begyüjtését megelőző napon állítottam össze. Az egyes oldatokat három-három tartóba öntöttem, melyekbe másnap 11-11 vesszőt állítottam. Az egyféle kezeléshez tartozó három-három edényt „,A”, „,B”, és „,C” jelzéssel láttam el. A kontrollként vízbe állított 33 vesszőt is háromfelé osztottam. Minden edénybe 2-2 dl folyadékot töltöttem. 


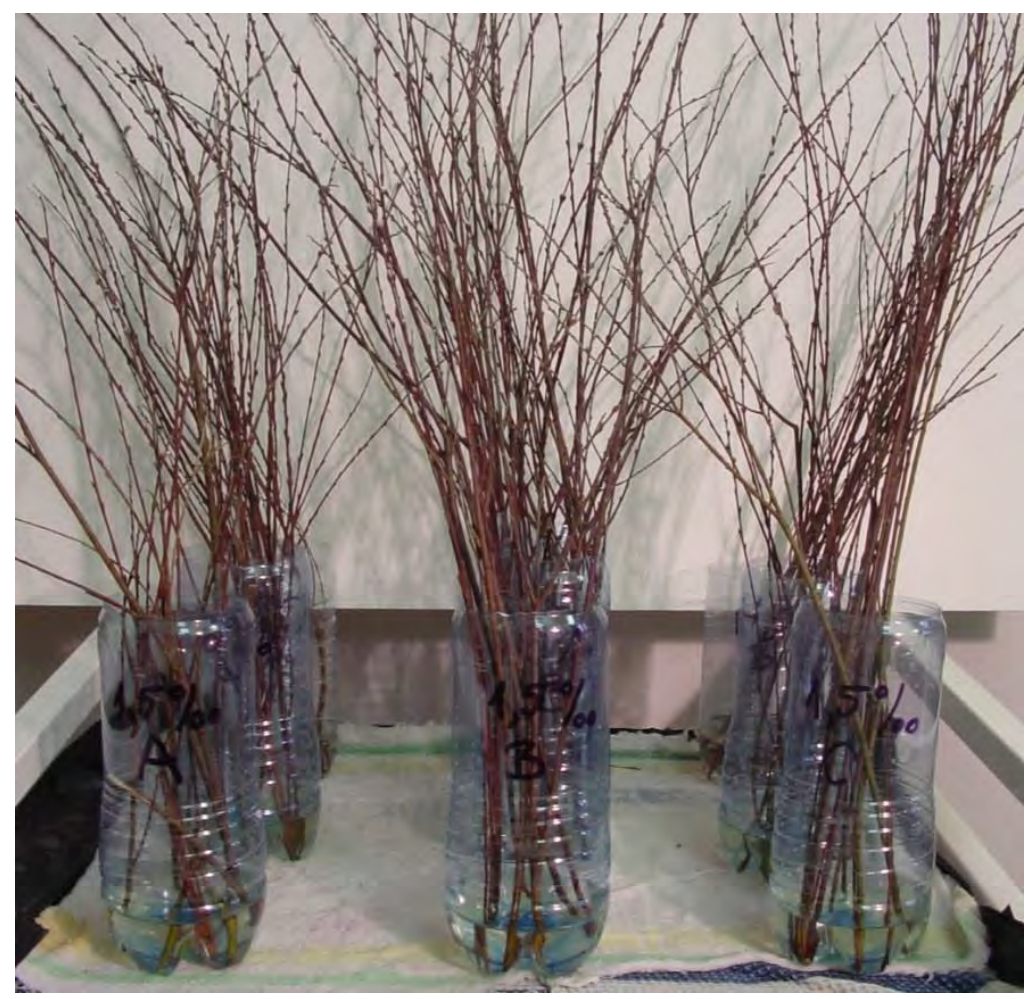

13. ábra: S. rosmarinifolia vesszők különböző nyílasztó oldatokban (fotó: Treerné, 2006)

A frissen szedett vesszőket a begyüjtés után azonnal Budapestre, a tanszéki laboratóriumba vittem, ahol szétválogattam őket a kilencféle edénybe. Mind a kilencbe 5-5 db-ot tettem az egyetlen sarjtelepről származó, közel azonos hosszú és vékony, egyszálas vesszőkből. Ezen túl mind a kilenc edénybe tettem egy-egy vastagabb, többéves ágat, melyekről több hosszú vessző is eredt. A három „A” jelü edénybe még 5-5 vesszőt tettem, melyek mind egyetlen sarjtelepről származtak, és melyek alja többéves részt tartalmazott. A „B” és „C” jelűekbe további 5-5 közepesen vastag, többéves részt is tartalmazó vessző került. Mielőtt vízbe vagy az adott oldatba állítottam volna, a vesszők alját szemzőkéssel ferdén visszavágtam.

Az edények alá frottírtörölközőt terítettem, melyet folyamatosan nedvesen tartottam a páratartalom növelése végett (13. ábra). Végül az egész kísérleti anyagot, melyet egy többszintes, gördíthető fém állványra helyeztem, fekete fóliával borítottam, hogy magasabb legyen a relatív páratartalom a kötegek közvetlen környezetében, és így csökkentsem a vesszők kiszáradásának veszélyét. Ezt követően egy hónapon keresztül rendszeresen figyeltem a vesszőket, és feljegyeztem a változásokat, a megpattant rügyek számát, arányát.

\subsection{Salix vesszők hosszú távú tartósítási lehetőségeinek vizsgálata}

2008 tavaszán három füz faj (S. rosmarinifolia, S. purpurea, S. caprea) vesszőivel végeztem tartósítási kísérleteket. A februárban szedett és kezelt vesszők rugalmasságát júniusig rend- 
szeresen mértem. Az eredmények kiértékeléséhez kvantitatív (mennyiségi, lásd 3.5.4 fejezet) és kvalitatív (minőségi, lásd 3.5.6 fejezet) módszereket alkalmaztam.

\subsubsection{A tartósítási kísérletben szereplő taxonok}

Salix caprea CA1 klón: A 4.1.1 fejezetben részletesen ismertetett, általam szelektált klón két éves töveiröl 2008. február végén 80 (kezelésenként 20 db) $90 \mathrm{~cm}$ hosszú vesszőt vágtam Soroksáron, és ezekkel végeztem el az alábbiakban részletezett négyféle kezelést.

Salix purpurea: A 4.1.2.2 fejezetben részletesen ismertetett PU2 klón vesszőiből 120 (kezelésenként $30 \mathrm{db}$ ) $90 \mathrm{~cm}$ hosszú vesszőt vágtam Soroksáron az alábbi kezelésekhez.

Salix rosmarinifolia: A 4.1.3.1 fejezetben részletesen ismertetett, 2006-ban általam szelektált, RO3 klón vesszőiből 2008. február 28-án Soroksáron vágtam a kísérlethez 100 szálat, minden kezeléshez 20 db 90 cm hosszú vesszőt.

\subsubsection{A tartósítási kísérlet során alkalmazott kezelések}

A $S$. caprea és $S$. purpurea klónok esetében az alábbi négyféle kezelést (F, H, HK, SK), $S$. rosmarinifolia esetében ötféle kezelést (F1, F2, H, HK, SK) végeztem a vesszőkkel.

1.) Száraz kontroll (SK): A vesszőket a Budapesti Corvinus Egyetem Dísznövénytermesztési és Dendrológiai Tanszékének laboratóriumában, szobahőmérsékleten (23-24 $4^{\circ}$ ), szárazon, $10 \mathrm{~cm}$ átmérőjü és $25 \mathrm{~cm}$ magasságú, henger alakú üvegvázában tartottam.

2.) Glicerines felszívatás (F): A tartósító oldat koncentrációját 2004-ben végzett tartósítási kísérleteim [TREERNÉ, 2005] alapján állítottam be, mert azt tapasztaltam, hogy a S. purpurea esetén az 50v/v\%-os koncentráció ad jobb eredményt, a $S$. caprea faj vesszőinek tartósításához elegendőnek bizonyult a 33v/v\%-os töménység (14. ábra). A S. caprea vesszők esetében glicerin és víz 1:2 arányú keverékét, a $S$. purpurea vesszők esetében glicerin és víz 1:1 arányú keverékét alkalmaztam felszívató oldatként. A glicerint 1000 ml-es kiszerelésben vettem az AZUR Kereskedelmi Rt. 0808. sz. boltjában. A vásárolt glicerin (1,2,3-trihidroxi-propán) 99,5\%-os (analitikai) tisztaságú volt. Desztillált vízzel higítottam, és a fentebb leírt vázába töltöttem, majd ebbe állítottam a kezelendő vesszőket. Mindkét taxon esetén 1-1 hétig tartott a felszívatás. A kezelést követően a vesszőket kivettem az üveghengerekből, szárukat tiszta vászonnal letöröltem, majd egy tiszta, száraz vázába állítottam a tanszéki laboratóriumban, ahol folyamatosan meg tudtam figyelni, illetve mérni a kísérlet következő hónapjai során. 

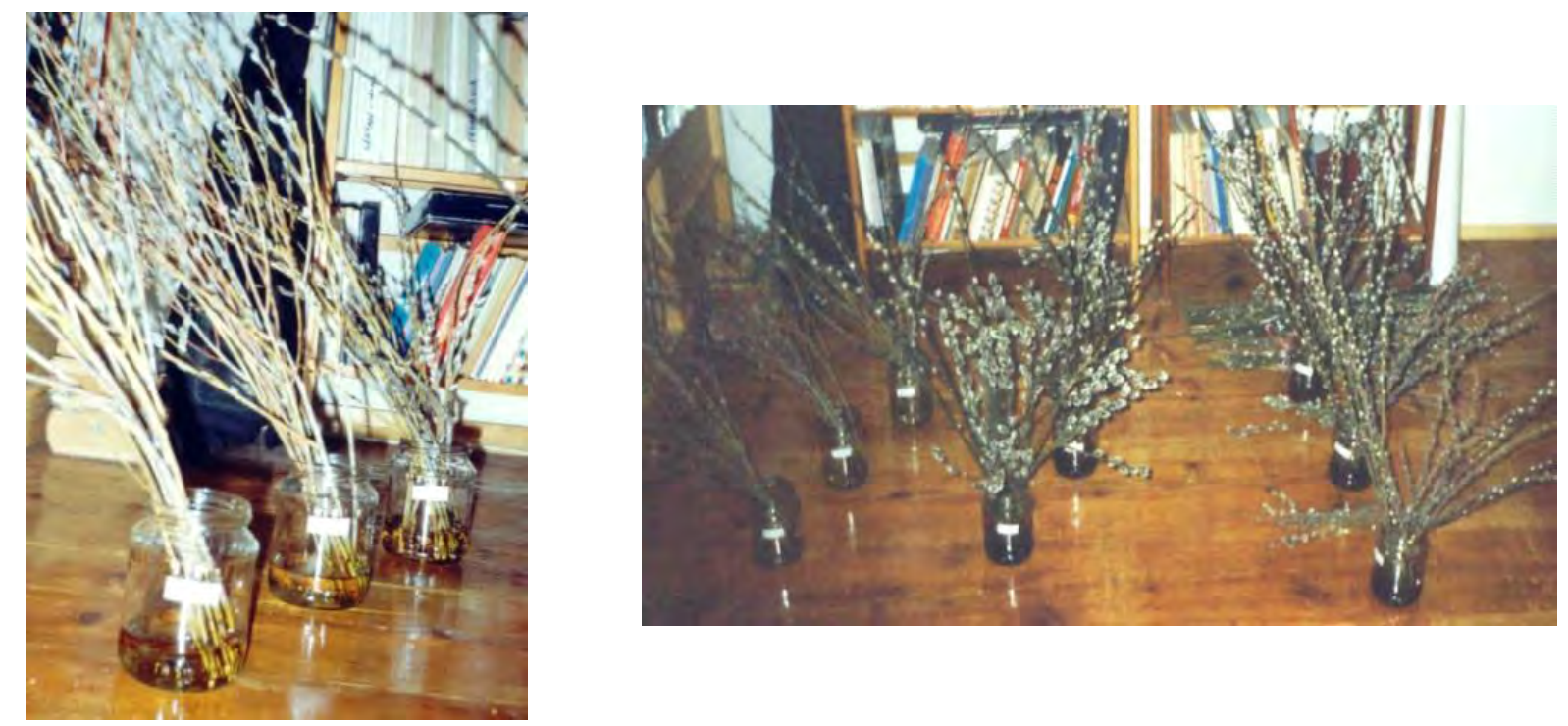

14. ábra: Salix vesszők glicerines tartósítása (balra: $S$. purpurea vesszők felszívatása közelről, jobbra: $S$. p., $S$. caprea és $S$. cinerea vesszők kezelése szobahőmérsékleten) (Budaörs, 2004. Fotó: Treerné)

S. rosmarinifolia vesszők (15. ábra) esetében kétféleképpen végzett felszívatás:

2/a.) Glicerines felszívatás 1 hétig (F1): A vesszőket glicerin és víz 1:1 arányú keverékébe állítottam. A $90 \mathrm{~cm}$ hosszú vesszők alsó $10 \mathrm{~cm}$-e ért a felszívató oldatba, a vesszők vázából kinyúló részét (az egész köteget együtt) fóliába (folpack) burkoltam, hogy csökkentsem a párologtatást, ezáltal a transzspiráció mértékét.

2/b.) Glicerines felszívatás 2 hétig (F2): A vesszőket a fent részletezett glicerines oldatba állítottam azzal a különbséggel, hogy ebben az esetben nem alkalmaztam fólia-borítást, azaz a vesszők szabadon álltak a vázában a tanszéki laboratóriumban, és összesen két hétig tartott a felszívatás, majd ezt követően szárazon, szobahőmérsékleten tartottam a vesszőket ugyanott.

3.) Szedést követő hütőtárolás $8 / 10$ napig $(\mathrm{H})$ : A vesszőket a szedést követően azonnal hűtőtárolóba vittem a Soroksári Tangazdaság Dísznövény telepén. Itt $4^{\circ} \mathrm{C}$ hőmérsékleten tartottam a barka-kötegeket. A hütve-tárolás a $S$. rosmarinifolia esetén nyolc, a $S$. caprea és $S$. purpurea esetében tíz napon keresztül tartott. Ezután a vesszőket

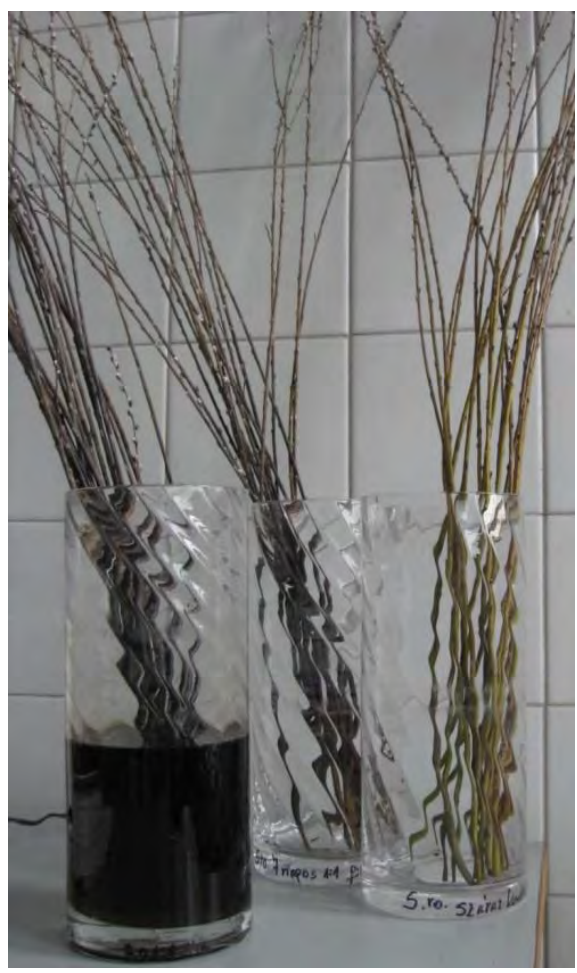

15. ábra: $S$. rosmarinifolia vesszők a tartósítási kísérletben (fotó: Treerné, 2008). kivettem, és a továbbiakban a tanszéki laboratóriumban tartottam, így imitálva egy termesztői hütőből a virágkötőhöz, illetve végfelhasználóhoz kerülö, barkás vesszőt tartalmazó csokor helyzetét. 
4.) Hütött kontroll (HK): A vesszöket a szedéstől az utolsó mérésig, 16 héten keresztül folyamatosan a soroksári hütőben tartottam $4^{\circ} \mathrm{C}$-on, és csak a mérések idejére vettem ki onnan. Ezeknek a vesszőknek a rugalmasságát Soroksáron, a fütetlen üvegházban mértem, a hütőhöz közel azonos hőmérsékleten.

\subsubsection{Mérési időpontok}

A rugalmasság pontos meghatározására szolgáló méréseket (a kísérlet beállitásakor végzett kiinduló mérést nem számítva) február végétől júniusig összesen hat időpontban ismételtem meg. Az első mérési időpont (T1) március első hete volt; a második mérési időpont (T2) március második hete; a harmadik mérési időpont (T3) március harmadik hete (2008. március 18.); a negyedik mérési időpont (T4) március negyedik, azaz utolsó hete volt. Az ötödik mérési időpont (T5) április első hetének vége (április 7. és 8.) volt, tehát itt az előző mérési időponthoz képest majdnem két hét telt el. Az utolsó, hatodik mérési időpont (T6) az előző mérést követően több mint két hónapra esett, ekkor, azaz június 18-án és 19-én már a kezelések hosszabb távú hatásai is megfigyelhetőek voltak.

\subsection{4 Új módszer Salix vesszők rugalmassági modulusának meghatározására}

Amikor elöször állítottam be kísérletet a vesszők tartósításával, az eredmények kiértékelésére felállítottam egy skálát, melyben 1-től 4-ig pontoztam a vesszőket azon tulajdonságuk szerint, hogy kézzel mennyire hajlíthatóak, illetve mely szögben pattannak meg, vagy törnek [TREERNÉ, 2005]. Ez az értékelés azonban meglehetősen szubjektív volt, ezért a vesszők rugalmasságát objektíven számszerüsítő módszert kerestem.

VERES et al. (2005) szegfü szárának törését vizsgálták szakítógéppel. Erre alapozva a gödöllöi Szent István Egyetem Gépészmérnöki Karán található egyszerü szakítógéppel vizsgáltam a veszszőket. Ám ez a módszer nem bizonyult alkalmasnak a rugalmasság mértékének megállapítására, ezért a lehajlás és hajlítás meghatározására alkalmas úgynevezett effektív Young-modulust alkalmaztam, mely értékkel számszerüsíteni lehet a különbözőféleképpen kezelt vesszők rugalmasságát. BUDÓ (1972) Mechanika címü alapmüvében szereplő képletekkel, és a következö módszerrel számszerüsíthetően ki tudtam számolni a vesszők rugalmasságát. 


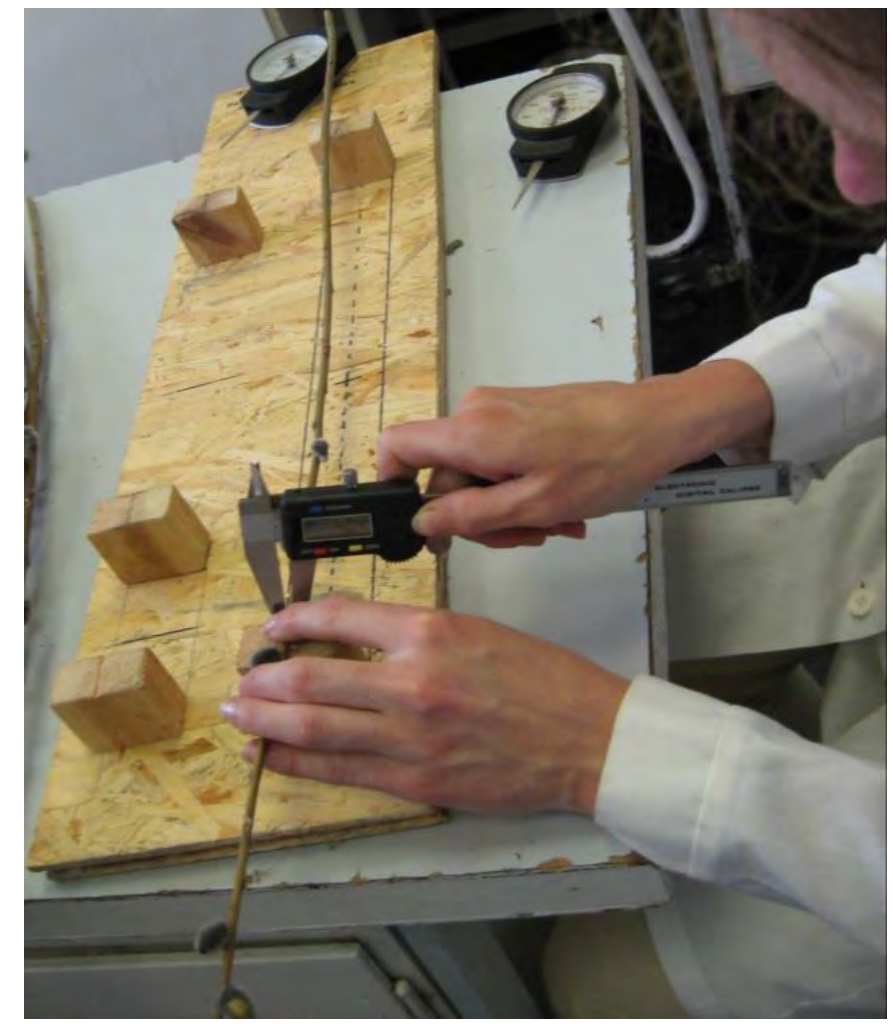

16. ábra: $S$. caprea vessző átmérőjének mérése

Legyártattam egy alap-támaszt: egy $20 \mathrm{~cm}$ x $70 \mathrm{~cm}$ alapterületü, $1,5 \mathrm{~cm}$ vastagságú farostlemezre $2 \times 2 \mathrm{db} 45 \times 40 \times 20 \mathrm{~mm}$-es hasábot szereltettem úgy, hogy a hasábok közül kettő $40 \mathrm{~cm}$-es távolságra, másik kettő pedig $25 \mathrm{~cm}$-es távolságra álljon egymással szemben, keskenyebbik lapjukkal alulról becsavarozva a lemezbe. A felület közepébe keskeny vájatot marattam, hogy a vesszőket mindig pontosan ugyanoda, a hasábok közepére tehessem, párhuzamosan a lemez hosszanti szélével. Ezen a támaszon tehát vesszőket lehetett felfektetni úgy, hogy azok két ponton legyenek alátámasztva, és a két pont távolsága 40, illetve $25 \mathrm{~cm}$ volt. Az alátámasztás magassága megegyezett a hasábok magasságával, azaz $40 \mathrm{~mm}$ volt. A rugalmassági modulus méréséhez, illetve kiszámításához szükséges még az adott vessző keresztmetszetének ismerete, valamint a 40 mm magasságból a lemezig történő lehajlításhoz szükséges erő.

A vesszők keresztmetszetét minden esetben ugyanott, a két támasztó hasáb mellett, a veszsző töve és csúcsa felé is megmértem a Precision Gold típusú elektronikus digitális tolómérővel, mellyel az értékeket két tizedesjegy pontossággal, milliméterben kaptam meg (16. ábra). A lehaj-

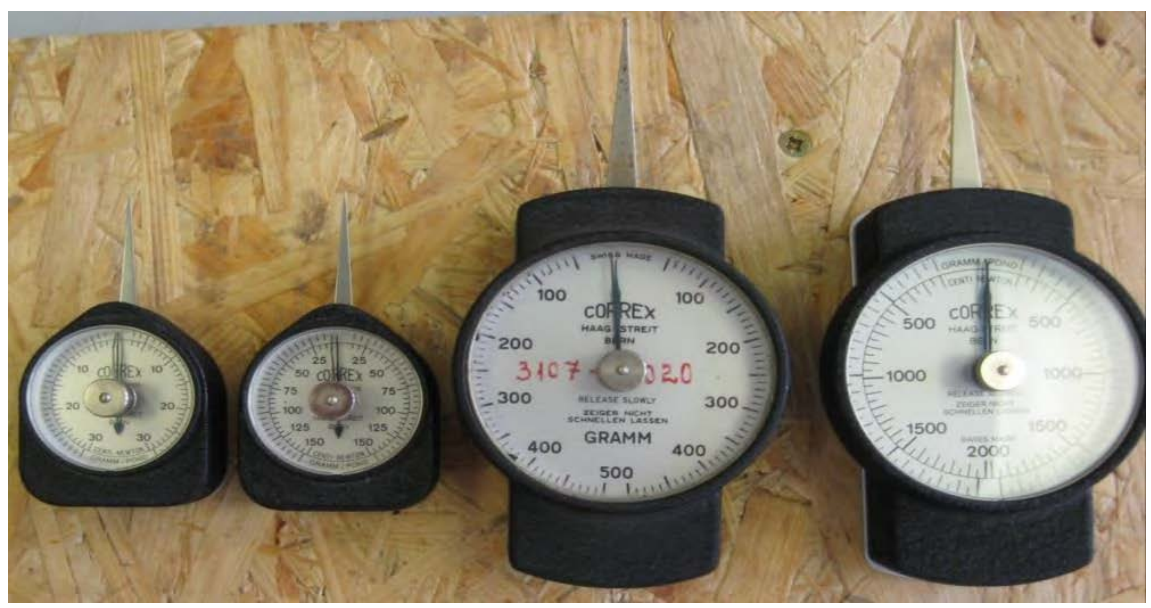

17. ábra: A vesszők hajlításához szükséges erő mérésére használt négy féle kézi erőmérő müszer (fotó: Treerné, 2008)

lításhoz szükséges erőt a vessző vastagságához (és rugalmasságához) mérten négy féle kézi erőmérő műszerrel mértem, pontosan a két támasz közötti felezőponton, mely be volt jelölve a le- 
mezen. A kézi erőmérő műszerekkel minden egyes vesszőn legalább háromszor ismételtem a mérést, hogy az esetleges pontatlanságot kiküszöböljem. Correx típusú kézi erőmérő műszereket használtam (17. ábra), melyek a mérési tartományban különböztek: 30 g; 150 g; 500 g; és 2000 g skálájúak voltak. Értelemszerüen, a hajlításhoz nagyobb erőkifejtést igénylő vastagabb vesszőket, mint a $S$. caprea vesszőit az 500 grammos vagy annál is nagyobb erőt mérő müszerrel, a $S$. purpurea vesszőihez az 500 grammos müszerre volt szükség, a S. rosmarinifolia filigrán, vékony vesszőit a 30 és 150 grammos (néha 500 grammos) müszerekkel mértem (18. ábra).

Egy rúd végének a lehajlása a következő képlettel számszerüsíthető [BUDÓ, 1972]:

$$
s=l^{3}[3 E I]^{-1} F
$$

ahol $s$ a lehajlás [m]; $l$ a rúd hossza (rögzítési ponttól a lehajlított végéig) $[\mathrm{m}] ; F$ a hajlításhoz szükséges erő $[\mathrm{N}]$; I a vessző felületi tehetetlenségi nyomatéka (esetünkben kör keresztmetszet másodrendü nyomatéka), és $E$ a rugalmassági modulus, melyet esetünkben effektívnek nevezünk, hiszen a vesszők anyaga nem homogén, de a számításoknál tekinthetjük kör keresztmetszetünek és homogénnek. Ez tehát az úgynevezett effektív Young-modulus, mellyel kifejezhetjük a vesszők rugalmasságát $\left[\mathrm{N}\left[\mathrm{m}^{2}\right]^{-1}\right]$.

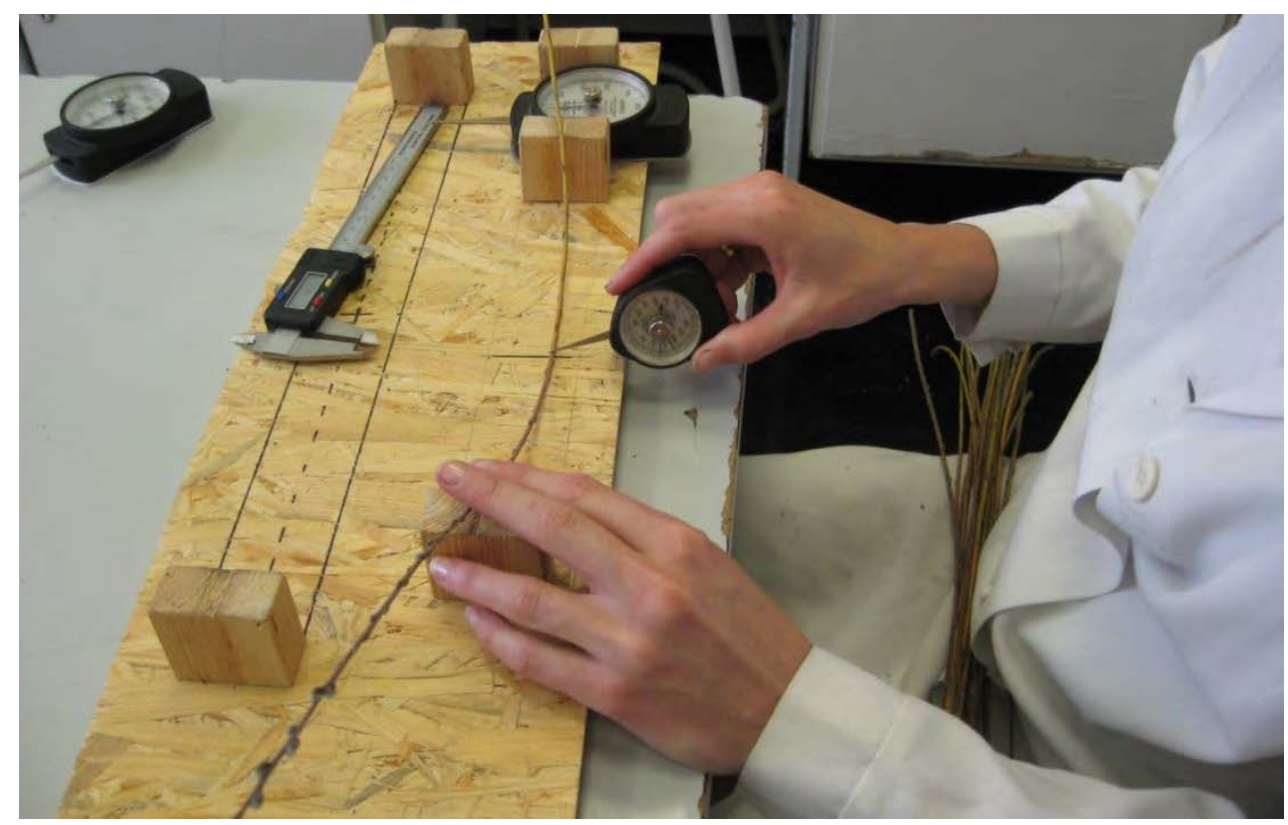

18. ábra: $S$. rosmarinifolia vessző hajlításához szükséges erő mérése kézi erőmérő müszerrel (2008)

Két végén rögzített (alátámasztott) rúdnál, mivel a két alátámasztás a rúd egy-egy végére $F / 2$ nyomóerőt fejt ki, és a rúd közepe vízszintes, vehetjük úgy, mintha egy $l / 2$ hosszúságú, egyik végén rögzített rúd másik végére $F / 2$ erő hatna. Ezeket az értékeket ( $l$-t és $F$-et) tehát felezve, a fenti képletbe behelyettesítve a következőt kapjuk: $s=l^{3} F[48 E I]^{-1}$

Az $I$ tehetetlenségi nyomaték $R$ sugarú kör keresztmetszetű rúd (vessző) esetén [BUDÓ, 1972. (54)]: $I=\pi[4]^{-1} R^{4}$ 
Ezt behelyettesítve az előző képletbe, és $E$-t kifejezve a rugalmassági modulus:

$$
E=l^{3} F\left[12 s \pi R^{4}\right]^{-1} \text {, ahol }
$$

- $\quad l$ : a vessző két rögzítési (alátámasztási) pontjának távolsága; konkrétan:

○ Salix caprea esetén $l=40 \mathrm{~cm}=0,4 \mathrm{~m}$

○ $S$. purpurea és $S$. rosmarinifolia esetén $l=25 \mathrm{~cm}=0,25 \mathrm{~m}$.

- F: a két alátámasztási pont között félúton ható, vesszőre gyakorolt, 40 mm-es hajlításhoz szükséges erő (grammból Newtonba átszámítva), kézi erőmérővel, 3x ismétléssel mérve

- $\quad s$ : a lehajlás mértéke, azaz a támaszok magassága $=40 \mathrm{~mm}=0,04 \mathrm{~m}$

- $R$ : a vesszők keresztmetszetének sugara (a vesszők két pontján mért átmérők átlagából számolva)[m]

A fenti képlet alapján pontosan kiszámolható $E$ érték tehát a vesszők rugalmassági modulusa, más néven az effektív Young-modulus. A mérésekkor minden egyes vessző keresztmetszetét, és a hajlításhoz szükséges $F$ erőt mértem a fent leírt kézi erőmérő műszerrel. Az általam kidolgozott mérési módszerrel kapott eredményeket a fent levezetett képlettel tovább számolva megkaptam a vesszők rugalmassági modulusát. A rugalmassági modulus értékeket az IBM SPSS programcsomag segítségével értékeltem ki többféle statisztikai módszerrel (ANOVA, Tukey-féle teszt, kétmintás T-próba). A kezelések eredményeit minden megfigyelési időpontban különkülön hasonlítottam össze statisztikai próbával, illetve megvizsgáltam azt is, hogy az egyes kezelések hatása változott-e az idő múlásával. Az elemzéshez variancia analízist használtam, ezen belül páronkénti összehasonlításokra a Tukey-féle tesztet. Esetenként, mikor csak két minta eredményeit kellett összevetnem, a kétmintás T-próbát alkalmaztam.

\subsubsection{A vesszők víztartalmának és víz-helyettesítési faktorának (Z-érték) meghatározása}

A szárazanyag-, illetve víztartalom meghatározását 2013. március és áprilisban végeztem a Budapesti Corvinus Egyetem, Kertészettudományi Kar, Dísznövénytermesztési és Dendrológiai Tanszék laboratóriumában. A vesszőket budaörsi kertemből szedtem ( $S$. caprea CA1 és $S$. rosmarinifolia $\mathrm{RO} 4)$ ötéves tövekröl.

A víztartalom meghatározásához BINDER ED53 típusú szárítószekrényt használtam (belső méretei: $33 \mathrm{~cm}$ mély; $38 \mathrm{~cm}$ széles). A $38 \mathrm{~cm}$ hosszú vesszők tömegét METTLER TOLEDO JL1502-G típusú mérlegen mértem, az értéket két tizedesjegy pontossággal grammban fejeztem ki. A friss tömeget, majd $100^{\circ} \mathrm{C}$-on két alkalommal végzett, 48 órás szárítást követően a száraz tömeget mértem. A szárított vesszők tömegét ismét megmértem fél, 2, 7, és 14 napot követően.

A Z-érték meghatározásához a friss $S$. caprea vesszőket glicerin és víz 1:2 arányú elegyébe, a friss $S$. rosmarinifolia vesszőket glicerin és víz 1:1 arányú elegyébe helyeztem. A felszíva- 
tást az előbbi esetben $500 \mathrm{~cm}^{3}$-es mérőhengerben, az utóbbi faj esetében $25 \mathrm{~cm}^{3}$-es méröhengerben végeztem (19. ábra). A vesszők tömegét megmértem a kezelés előtt, valamint a felszívatást követően. A víz-helyettesítési faktor számítása az előbbiekből:

Z-érték $=($ felvett oldat $*$ glicerines oldat tömegszázaléka $) *$ (tartósítandó növény friss tömege * adott növény víztartalma \%-ban $)^{-1}$

A szárított, valamint a glicerinnel felszívatott kötegek morfológiai paramétereit (barkák mérete, vesszők színe, barkák hullása a vesszőkről, stb.) négy héten keresztül mértem.

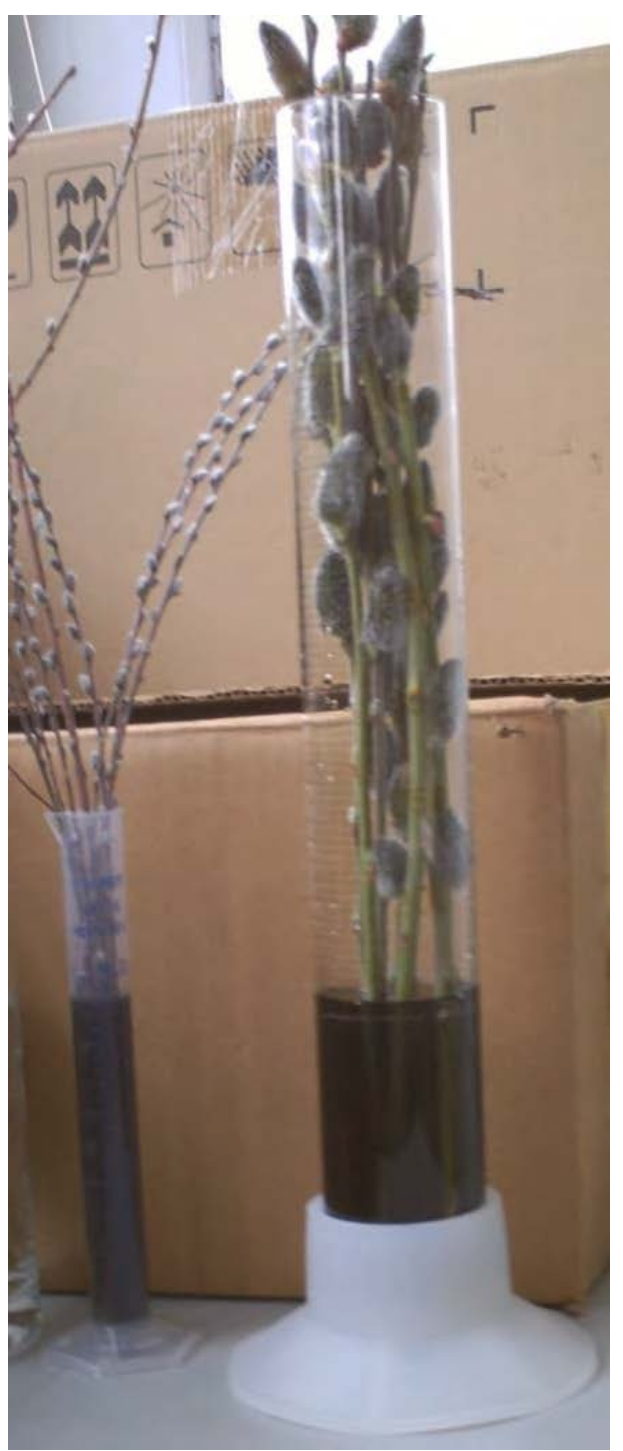

19. ábra: $S$. rosmarinifolia és $S$. caprea vesszők felszívatása (fotó: Treerné, 2013)

\subsubsection{Morfológiai paraméterek értékelésének módszere}

A rugalmasság mérésén túl a vesszők megfigyeléséhez elektronikus digitális tolómérőt használtam (Precision Gold típusú Electronic Digital Calipers), mellyel két tizedesjegy pontossággal, milliméterben lehetett mérni a barkákat, illetve ezek méretbeli változásait. A felszívató oldatok kémhatását univerzális pH-mérő csíkkal mértem. A kezelések hatásának értékeléséhez a barkás vesszőkön a következő paramétereket, illetve azok változásait figyeltem meg és jegyeztem fel: vesszőszín, barkák mérete és állapota (pl. fejletlen, megnyúlt virágzati tengely, virágzó), rügypikkely és a rügypikkely takarásából kilátszó barka aránya, barkák és rügypikkelyek hullása (fennmaradó és leeső barkák száma vagy aránya), vesszők és barkák tapintása (pl. puha/rideg, kemény, olajos/száraz, sima/érdes), a barka tengelyének a vesszővel bezárt szöge. 


\section{EREDMÉNYEK}

\subsection{Barkás vessző termesztés céljából szelektált Salix klónok morfológiai és fenológiai jellemzői, vesszőhozama és gyökeresedése}

3. táblázat: Szelektált Salix klónok botanikai leírása

\begin{tabular}{|c|c|c|c|c|c|c|c|c|}
\hline \multicolumn{2}{|r|}{ Klón kódja } & CA1 & PU1 & PU2 & RO1 & $\mathrm{RO} 2$ & RO3 & RO4 \\
\hline \multicolumn{2}{|r|}{ Fantázia-név } & $\begin{array}{c}\text { Big } \\
\text { Black }\end{array}$ & \begin{tabular}{c|} 
Green \\
Robust
\end{tabular} & Purple Lace & $\begin{array}{l}\text { Straight } \\
\text { Gold }\end{array}$ & $\begin{array}{c}\text { Green } \\
\text { Creeper }\end{array}$ & $\begin{array}{l}\text { Straight } \\
\text { Orange }\end{array}$ & Straight Scarlet \\
\hline \multicolumn{2}{|r|}{ Vesszö-szín } & $\begin{array}{l}\text { zöldes } \\
\text { barna }\end{array}$ & $\begin{array}{c}\text { sárgás } \\
\text { zöld }\end{array}$ & fényes bordó & sárga & $\begin{array}{l}\text { élénk } \\
\text { zöld }\end{array}$ & narancs & bordó \\
\hline \multicolumn{2}{|r|}{ 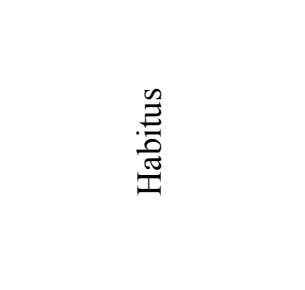 } & 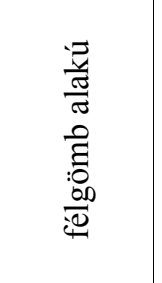 & 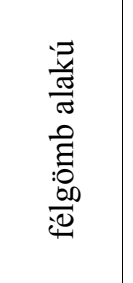 & 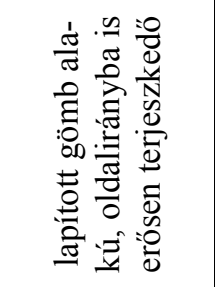 & 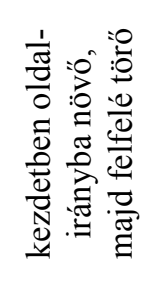 & 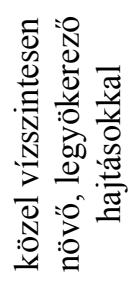 & 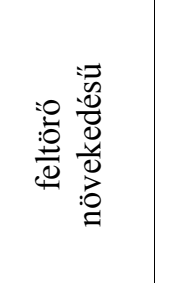 & 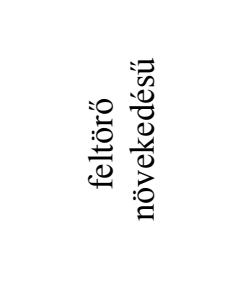 \\
\hline \multirow{2}{*}{ 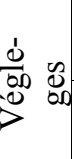 } & \begin{tabular}{|c|}
$\begin{array}{c}\text { Növ. magasság } \\
(\mathrm{cm})\end{array}$ \\
\end{tabular} & $230-280$ & 270 & $300-320$ & $100-150$ & $40-60$ & $160-180$ & $100-140$ \\
\hline & Tő átmérö $(\mathrm{cm})$ & 250 & 270 & $300-350$ & $80-100$ & $80-100$ & 180 & $80-100$ \\
\hline \multirow{7}{*}{ 总 } & $\frac{\frac{1}{\sigma}}{\sigma}$ & 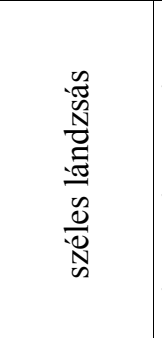 & 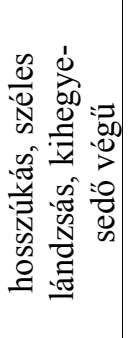 & 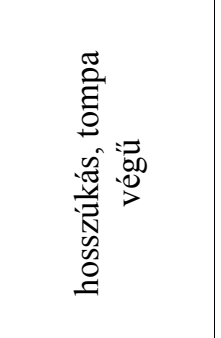 & 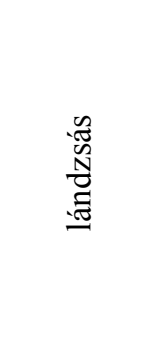 & 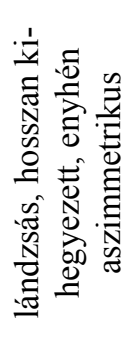 & 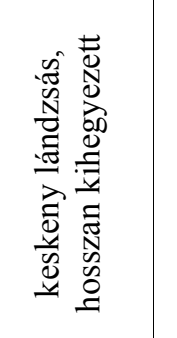 & 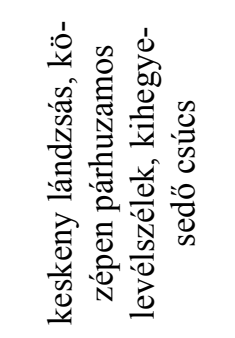 \\
\hline & hossz (mm) & 100 & 120 & 80 & $45-50$ & $50-60$ & $40-50$ & $40-50$ \\
\hline & szélesség (mm) & $20-30$ & 15 & 15 & $8-10$ & $10-12$ & $4-5$ & $10-12$ \\
\hline & legszélesebb & $\begin{array}{c}\text { 1. közép / } \\
\text { felső } \\
\text { harmad }\end{array}$ & $\begin{array}{l}1 . \\
\text { közép }\end{array}$ & felső harmad & $\begin{array}{l}\text { középsö / } \\
\text { alsó har- } \\
\text { mad }\end{array}$ & $\begin{array}{l}\text { közép- } \\
\text { tájék }\end{array}$ & \multicolumn{2}{|c|}{ 1. közép / alsó harmad } \\
\hline & 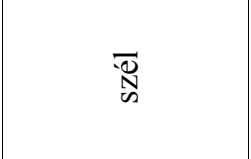 & 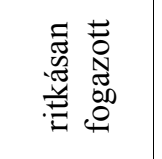 & 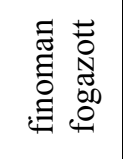 & 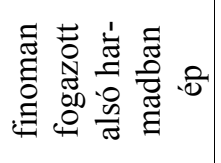 & 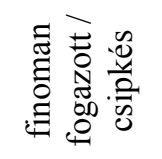 & 웡 & 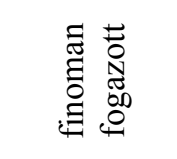 & 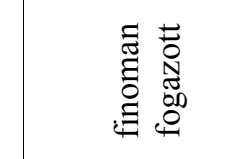 \\
\hline & 零 & 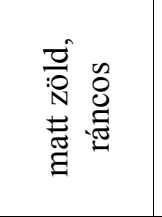 & 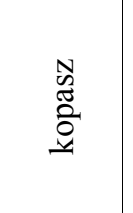 & 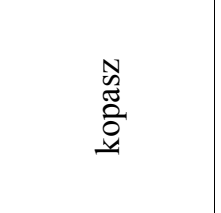 & 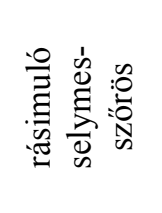 & 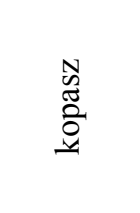 & 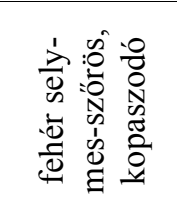 & 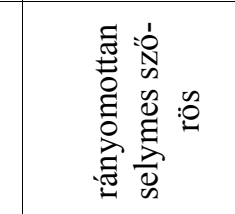 \\
\hline & 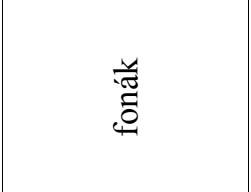 & 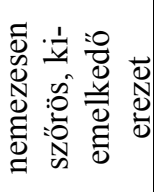 & 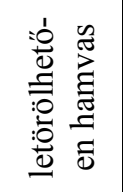 & 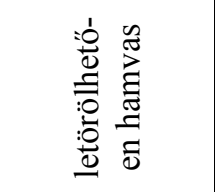 & 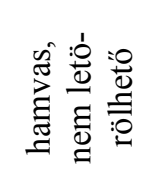 & 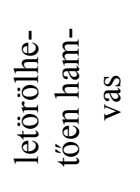 & 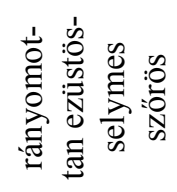 & 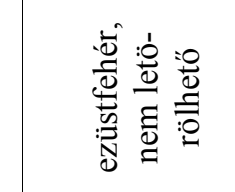 \\
\hline & $\begin{array}{l}\text { vélnyél hossza } \\
(\mathrm{mm})\end{array}$ & 10 & 6 & 8 & $2-2,5$ & $1-1,5$ & 3 & $3-4$ \\
\hline & 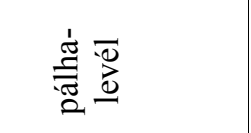 & 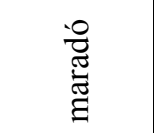 & $\stackrel{\circ}{\bar{\Xi}}$ & $\stackrel{\circ}{\bar{\Xi}}$ & 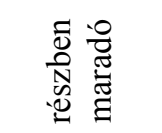 & 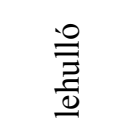 & 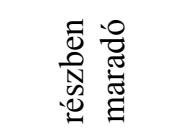 & 兰 \\
\hline
\end{tabular}


Az általam szelektált klónok morfológiai leírását, jellemzését, melyet a 3. táblázat tartalmaz, nem ismétlem meg, csak egyéb tulajdonságaikat (pl. vesszőhozam) ismertetem röviden a következő alfejezetekben. Mindegyik klón porzós.

\subsubsection{Salix caprea CA1 klón}

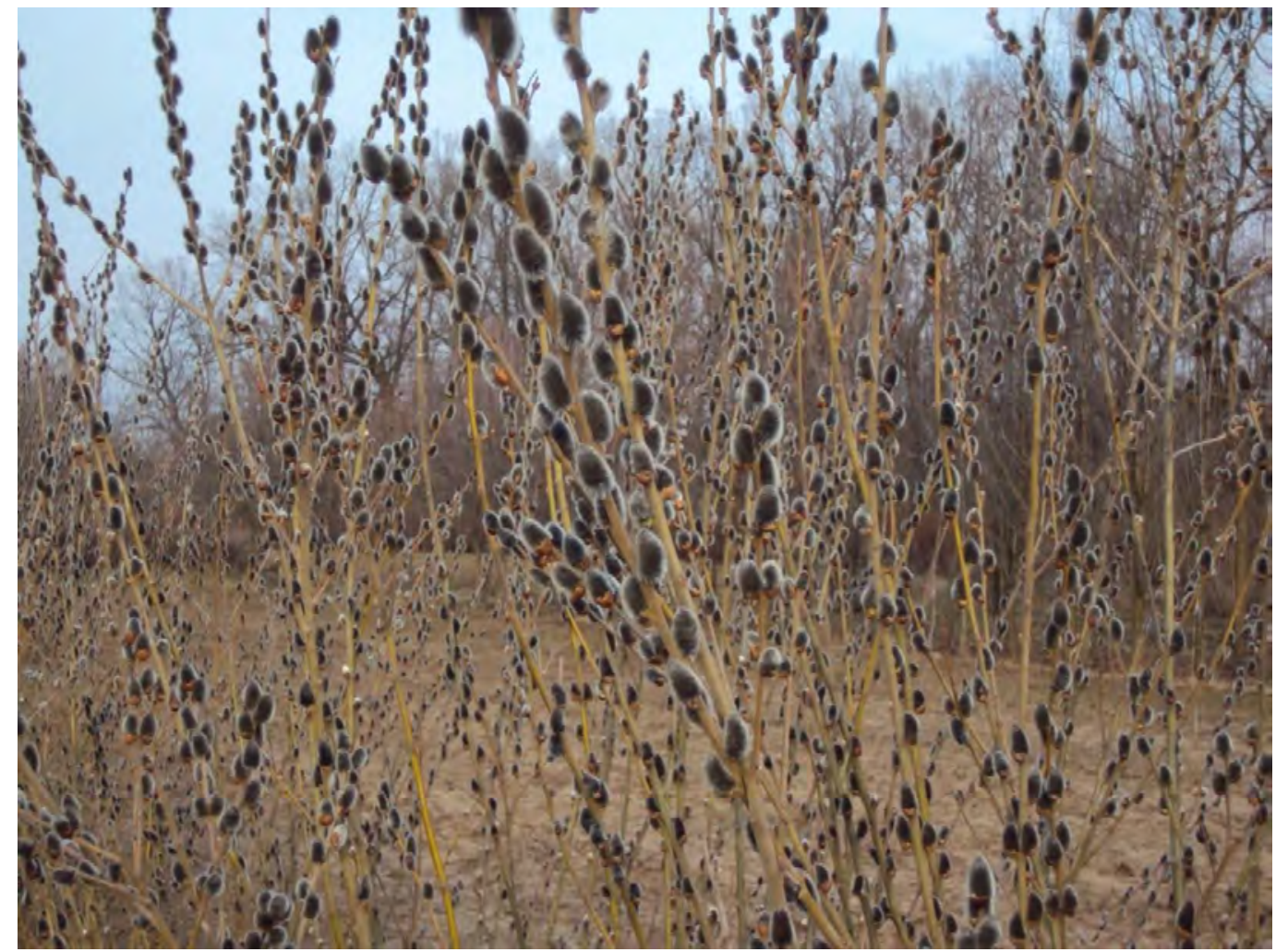

20. ábra: S. caprea CA1 klón barkás vesszői március 18-án (fotó: Treerné, 2010)

A Csepel-sziget déli csúcsán lévő állományban ez a növény volt az egyetlen tő ilyen feltünően sötét színű barkákkal, a gyüjtők erről vágták a vesszőket. Fantázianeve a rendkívül dekoratív, nagyméretü, fekete barkákra utal (20. ábra). A barkák a sötét fekete murvapikkelyeknek, és a rajtuk lévő viszonylag rövid szőröknek köszönhetően feltűnő fekete színűek. Egy virágzatból kipreparált csupasz virágot mikrotechnikai módszerekkel vizsgáltam. A fekete murvapikkelyből metszetet készítettem, mely a fonákán lévő erekkel az I. poszteren (M8. melléklet, 153. o.) látható. A murvapikkelyen található szőrök egysejtüek, hengeresek, csúcsuk kihegyesedő. A virágzatban a murvapikkelyek töve éretlenül zöld, csúcsa kezdetben sötétrózsaszín, majd a csúcs felöl kezdve megfeketedik fény hatására (21. ábra és 22. ábra). 


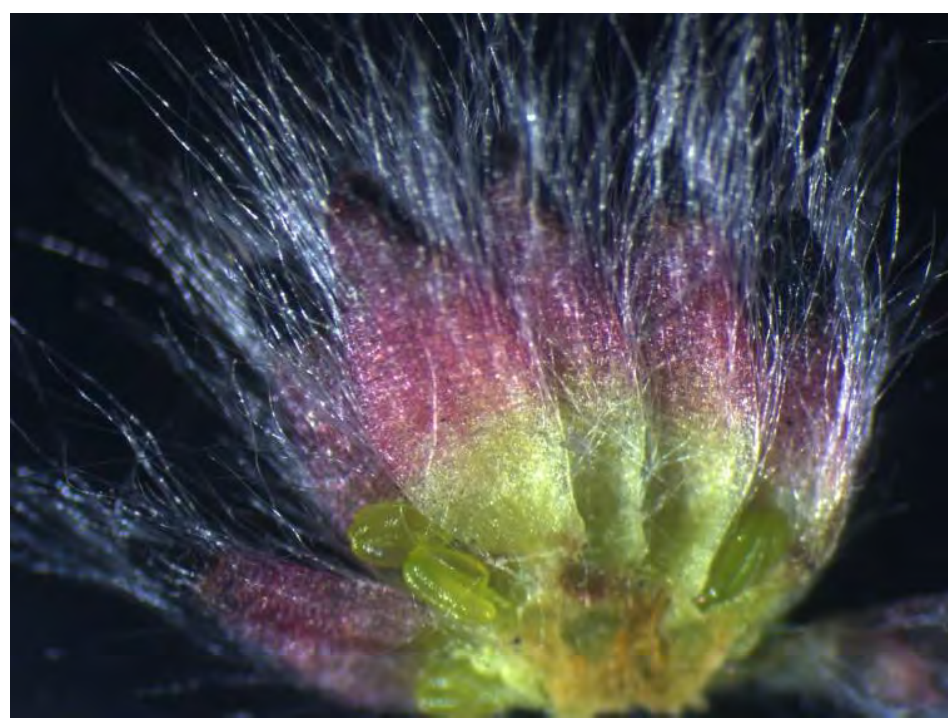

21. ábra: $S$. caprea CA1 barka keresztmetszet murvapikkelyekkel és portokokkal (3x nagyítás, fotó: Reményi, 2013)

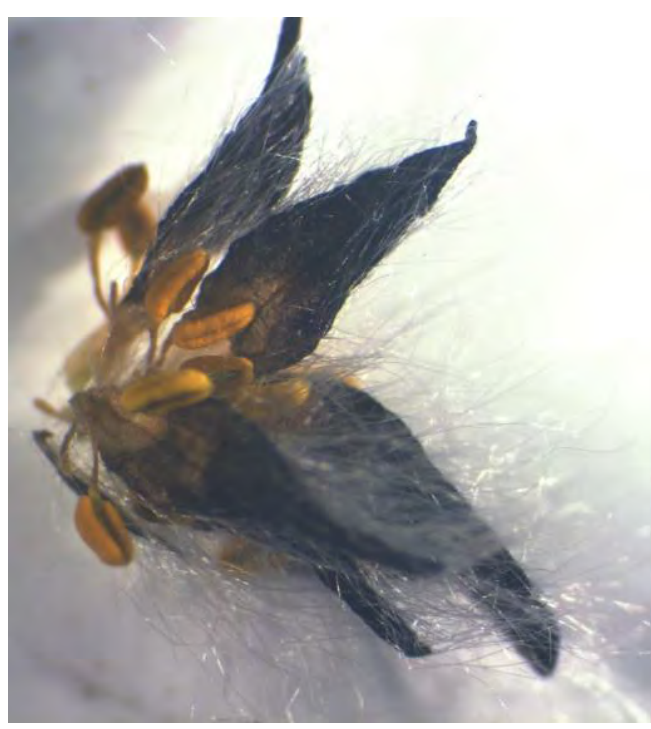

22. ábra: $S$. caprea CA1 klón porzós virágai megfeketedett murvapikkelyekkel (2x nagyítás, fotó: Reményi, 2013)

Az egyéves növényekről átlagosan tövenként 6,1 db barkás vesszőt szedtem, melyek 86,5\%-ban II. osztályú, 12,5\%-ban I. osztályúak voltak. Bokros vessző alig (1\%), Extra egyáltalán nem fejlödött a dugványozást követő első évben. A kétéves töveken már nagyobb arányban (40\%) termett I. osztályú vessző, és 10,3\% Extra méretüt is betakarítottam (4. táblázat).

4. táblázat: $S$. caprea CA1 klón barkás vesszőinek mérete és \%-os megoszlása

\begin{tabular}{|c|c|c|}
\hline Vessző hossza (cm) & Kategória & $\begin{array}{c}\text { Kategóriák megosz- } \\
\text { lása 2-5 éves tövek } \\
\text { esetében }(\%)\end{array}$ \\
\hline $120-150$ & Extra & 18 \\
\hline $90-120$ & I. o. & 35 \\
\hline $60-90$ & II. o. & 34 \\
\hline $60-90$ és $90-120$ & Bokros & 13 \\
\hline
\end{tabular}

A következő években tovább nőtt az Extra méretű vesszők aránya (23. ábra, következő oldal). Az összes leszedhető vesszőszám közel azonos maradt, tövenként átlagosan 32,4 db (2 éves növény) és 31,6 db (5 éves növény). A tövekröl már a dugványozást követő második évben jelentős mennyiségű vesszőt tudtam betakarítani, de a növények csak a harmadik évben érték el végleges méretüket. Ezt a rendszeres visszavágás következtében több éven keresztül megtartották (24. ábra, következő oldal). 


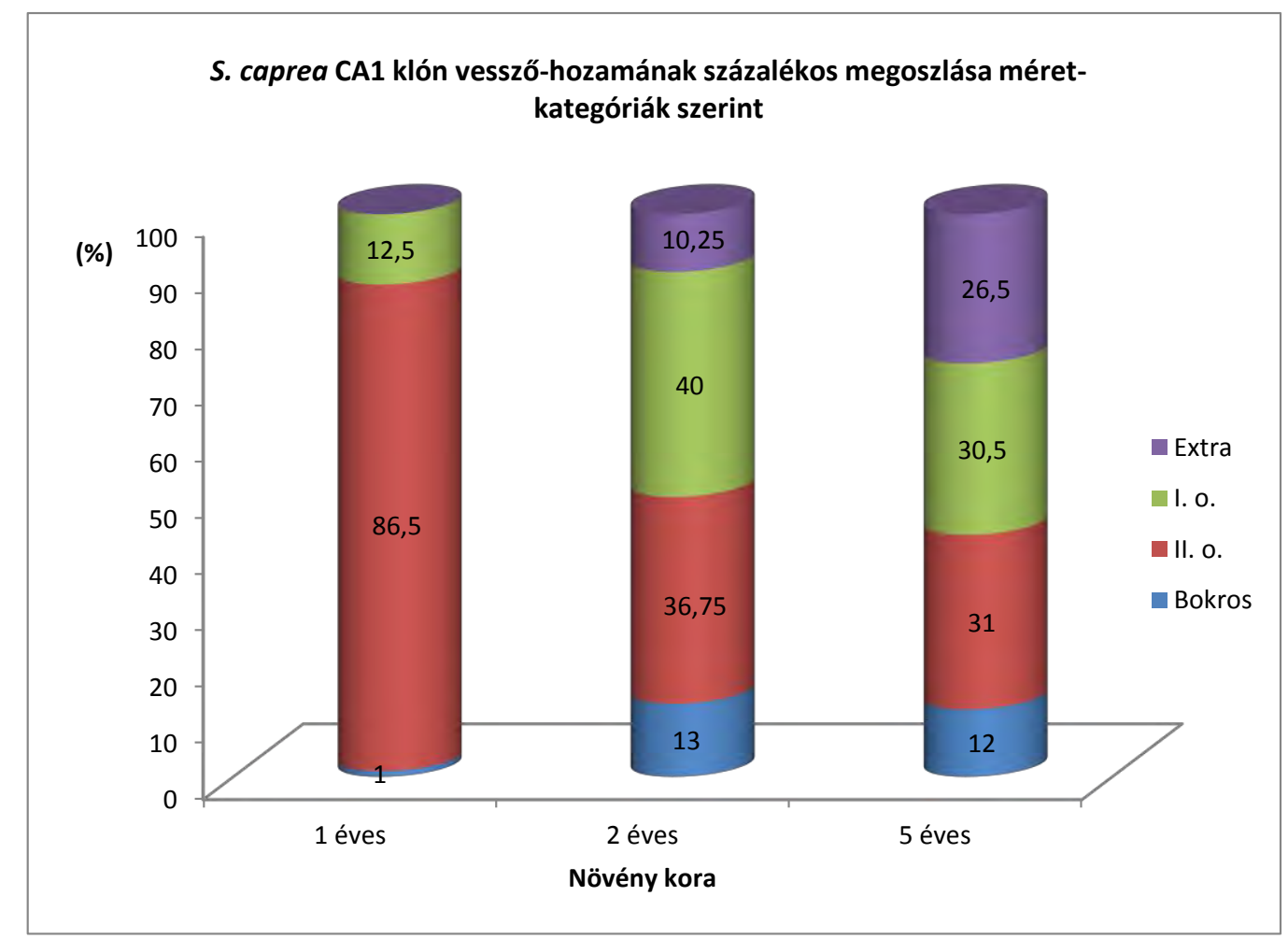

23. ábra: $S$. caprea CA1 klón vesszőhozamának százalékos megoszlása méret-kategóriák szerint

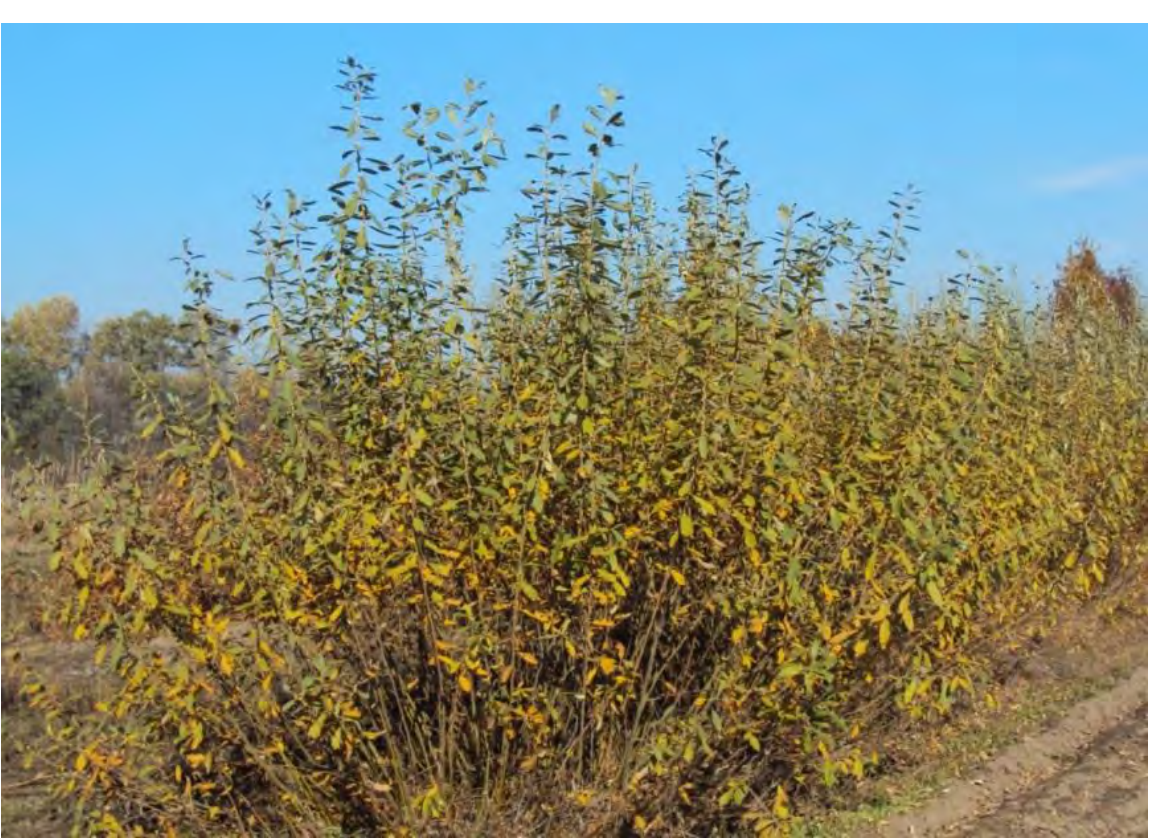

Az általam szelektált klónok közül ez virágzott legkorábban, ennek veszszőit kellett leghamarabb betakarítani. A virágzati rügyek 2008-ban már január végén megpattantak, február 26-án pedig a dekoratív barkák murvapikkelyei közül több helyen kinyúltak a sárga portokokat tartó porzószálak. Az

24. ábra:Három éves $S$. caprea CA1 klón tövek október végén (fotó: Treerné, ilyen áru már nem értéke2010)

síthetö. Ugyanakkor 2010ben és 2011-ben még március közepén is piacképes állapotban maradtak a vesszők a töveken. A virágzatokban a murvapikkelyek között már láttam a kifejlődött portokokat, de a porzószálak még nem nyúltak meg. Egy hét múlva, március végén az egész ültetvény kivirágzott. 


\subsubsection{Salix purpurea klónok}

\subsubsection{Salix purpurea PU1 klón}

Vesszöi Dél-Somogyból származnak. Fantázianeve a növény robusztus habitusára, vastag, sárgászöld színü vesszőire utal (25. ábra). Levelei gyakran látszólag keresztben átellenesen állnak. Hosszúkás, vastag barkáit a másodrendủ elágazásokon hozza gyakran párosával, látszólag keresztben átellenesen vagy hármasával, örvszerüen.

Rendkívül intenzív növekedésü, már az első évben piacképes barkás vesszőket szedtem róla. A dugványozás évében dugványonként két-három hosszú hajtás nőtt, melyeken a másodrendủ elágazásokon fejlődtek barkák. Hosszú hajtásonként

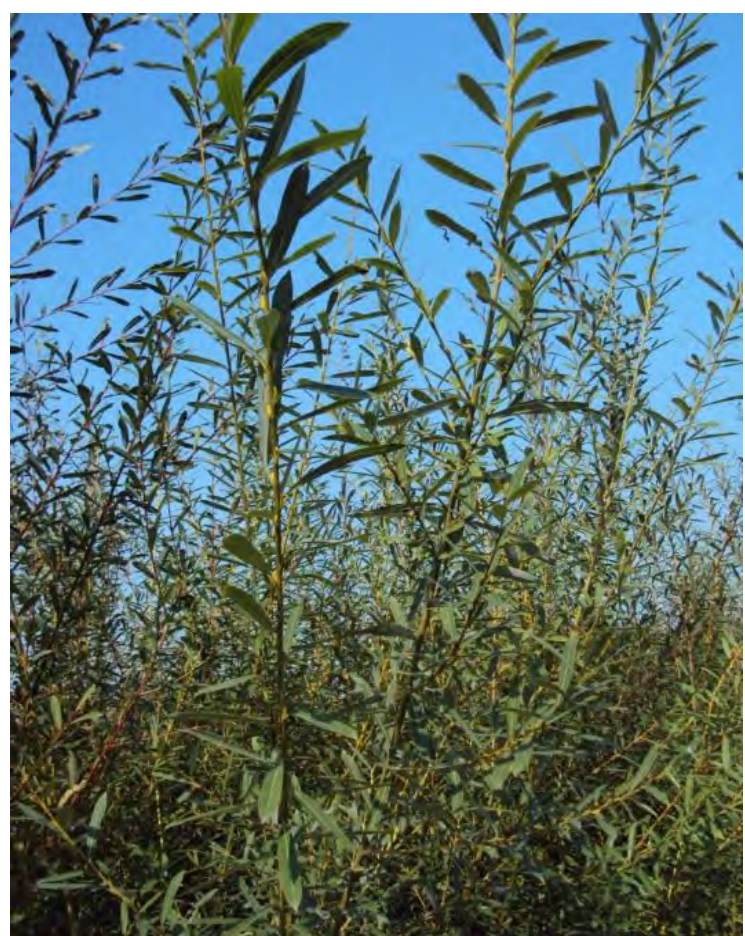

25. ábra: S. purpurea PU1 klón október 14-én (fotó: Treerné, 2010) átlagosan 2,8 db rövidebb másodrendü hajtás fejlödött, ezekből lettek a 40-100 cm hosszúságú barkás vesszök a következő év tavaszára. A betakarítás igen munkaigényes volt, minden évben tövig vissza kellett vágni a növényeket, a barkás vesszők leválogatásával egyidejűleg a piacképes áruval azonos mennyiségủ hulladék vessző keletkezett. Szükséges a tövek rendszeres erős visszavágása, különben kezelhetetlenül nagyra nő és szétesik a bokra. Ez a klón tovább maradt zöld, mint a többi Salix taxon, lombját ősszel akár december közepéig-végéig megtartotta (26. ábra).

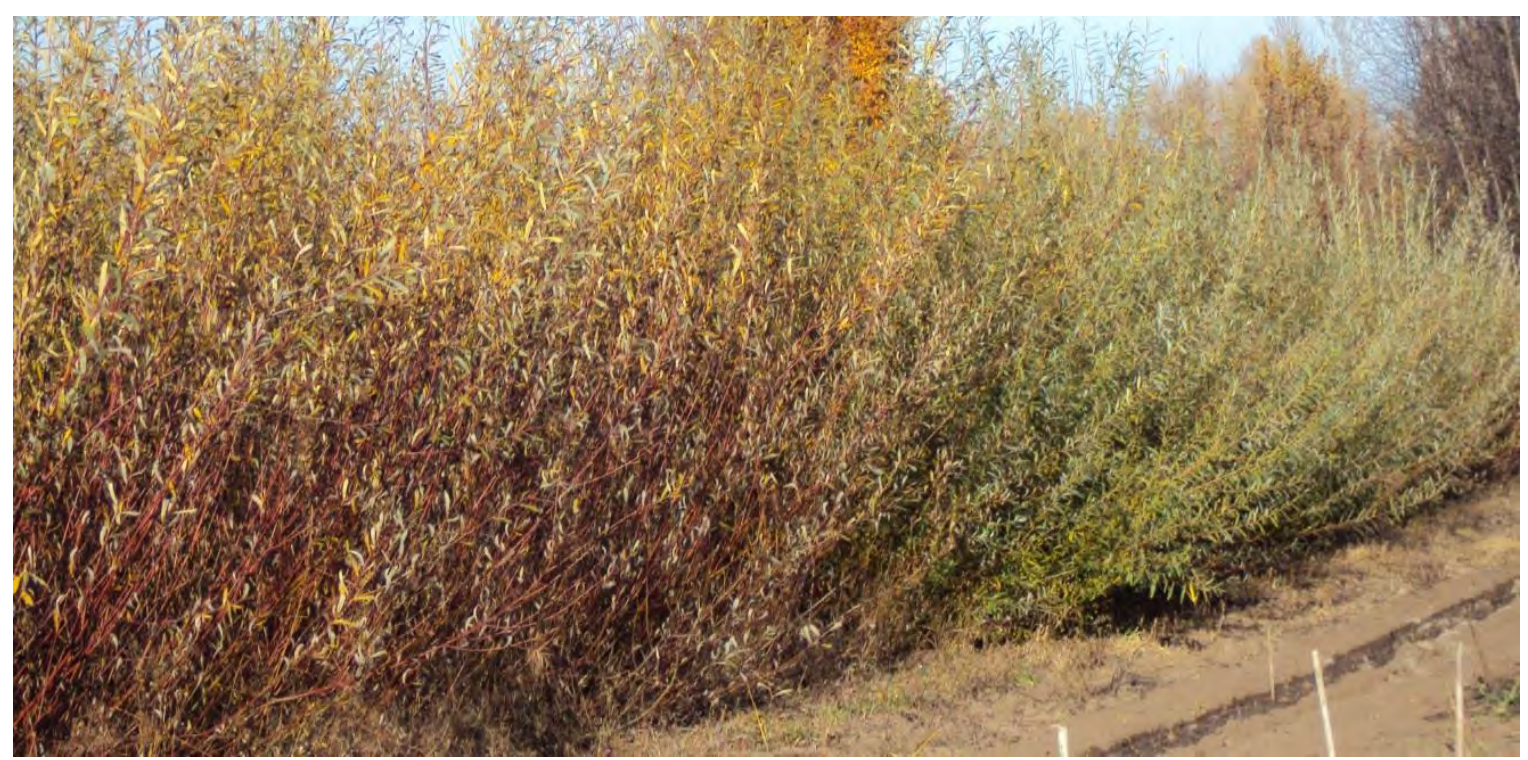

26. ábra: S. purpurea PU2 (balra) és PU1 (jobbra) klónok november elején (fotó: Treerné, 2010) 


\subsubsection{Salix purpurea PU2 klón}

Feltünően bordópiros vesszőszínü klón (27. ábra), barkás vesszőit Zala megyében gyüjtötték. Fantázianeve a vékony, színes vesszők csipkeszerü hálózatára utal. Közel azonos magasságú és szélességú cserje, hosszú, többszörösen elágazó, filigrán megjelenésü, fényes, bordó vesszőkkel. Hosszúkás füzérvirágzatait a veszszők másod- vagy harmadrendủ elágazásain hozza.

Az első évben átlagosan 3-5 db, a későbbi években a tavaszi visszavágást követően 6-8 db erőteljes hajtás fejlödött a töveken. Ezekröl a másod-, illetve harmadrendủ elágazások levágásával átlagosan 4,1 db, barkával teljes hosszában berakódott vesszőt kaptam. A barkás veszszőket öt kategóriába soroltam, mivel a bokros, elágazódó vesszők, továbbá a másod- és harmadrendủ elágazások hossza igen széles tartományban mozgott (5. táblázat).

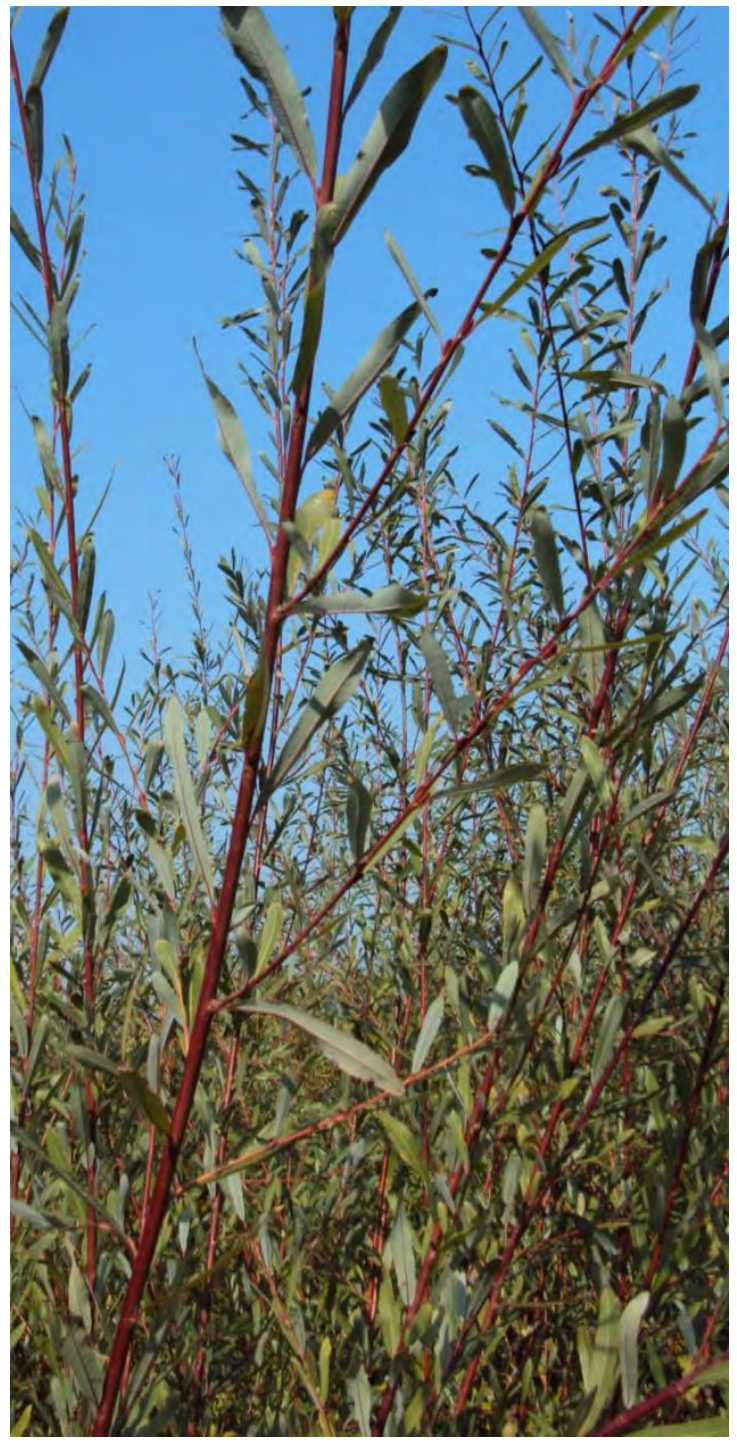

27. ábra: S. purpurea PU2 klón leveles bordó hajtása ősszel (fotó: Treerné, 2010)

5. táblázat: $S$. purpurea PU2 klón barkás vesszőinek mérete és \%-os megoszlása

\begin{tabular}{|c|c|c|}
\hline Vessző hossza $(\mathrm{cm})$ & Kategória & $\begin{array}{c}\text { Kategóriák megoszlása 2-5 éves } \\
\text { tövek esetében (\%) }\end{array}$ \\
\hline $160-190$ & Extra & 11 \\
\hline $120-160$ & I. o. & 18 \\
\hline $90-120$ & II. o. & 8 \\
\hline $0-90$ & III. o. & 58 \\
\hline 180 & Bokros & 5 \\
\hline
\end{tabular}

A S. purpurea klónok Soroksáron és Egeralján is 100\%-ban gyökeresedtek. Egy 2007 évben, ősszel végzett kísérlet során azt tapasztaltam, hogy vízbe állított, lelevelezett vesszői 100\%ban, intenzíven gyökeresedtek: egy hét alatt már 8-10 mm-es, két hét múlva már 8-10 cm-es gyökereik voltak. Ezzel szemben a PU1 (zöld vesszőszínü) klón vízbe állított vesszöi lassabban gyökeresedtek, a vízbe állítást követően a második héten jelentek meg rajtuk a kalluszcsomók. 


\subsubsection{A rügypikkely leválásának sajátosságai}

Kizárólag a $S$. purpurea fajnál figyeltem meg egy jelenséget, melyet szakirodalomban tudomásom szerint mások nem közöltek eddig. A rügypikkelyek a többi füz fajjal ellentétben nem a vessző felöli oldalukon felhasadva esnek le a barkákról. A rügypikkely töve a vessző felőli oldalon kezdve körben elválik a füzérvirágzat alapi részétől, és egyben maradva, mint egy apró cső, a növekedő barkáról hosszanti irányban lecsúszik (28. ábra).

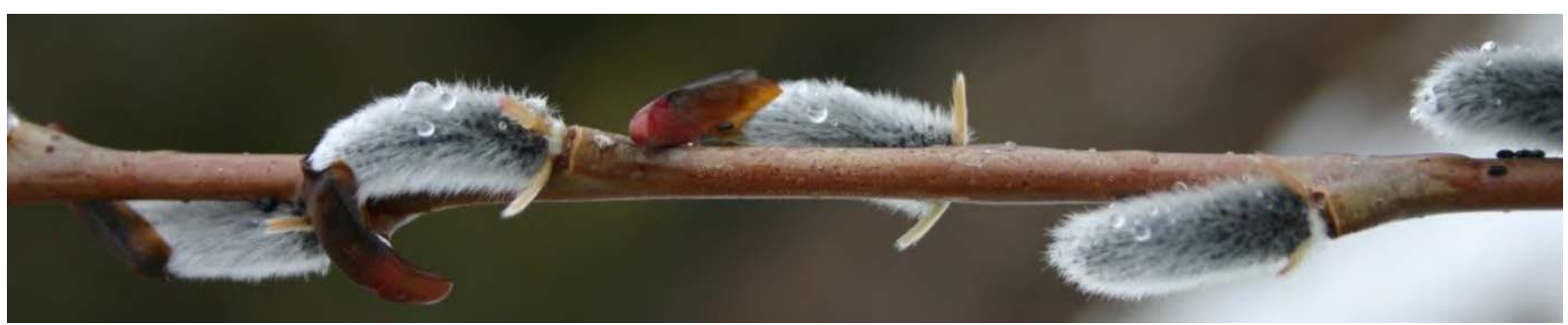

28. ábra: A rügypikkely sajátos leválása $S$. purpurea esetén (fotó: Treerné, 2008)

Ilyen típusú leválás esetében nem fordulhat elö, hogy a száraz rügypikkely fennmarad a barka tövében, mint a többi barkás vesszőként alkalmazható Salix fajnál. A füzérvirágzat tengelyének megnyúlásával elkerülhetetlenül eltávolodik a rügypikkely töve a vesszőtől, végül megfelelő támaszkodás hiányában leesik. E faj esetében tehát kivétel nélkül minden barkáról leválik a rügypikkely még jóval a teljes virágzás előtt, a füzérek megnyúlásával egy időben. A díszítőérték szempontjából ez igen nagy jelentőséggel bír.

\subsubsection{Salix rosmarinifolia klónok}

\subsubsection{Salix rosmarinifolia RO1 klón}

Vesszőit Tapolca környékén gyüjtötték. Fantázianeve a sárga színü, felfelé növekedő, egyenes vesszőkre utal (29. ábra). A 2004-ben végzett szabadföldi dugványozáskor az eredés 26,3\%-os volt. Az első év őszére három-négy, átlagosan 50-70 cm-es hajtás fejlödött tövenként, a második évben már többségében 70-80 cm-es vesszőket szedtem róla. A dugványozást követő harmadik évtől kezdve átlagosan 60-120 cm-es vesszőket hozott minden tavasszal (6. táblázat, 30. ábra - a következő oldalon).

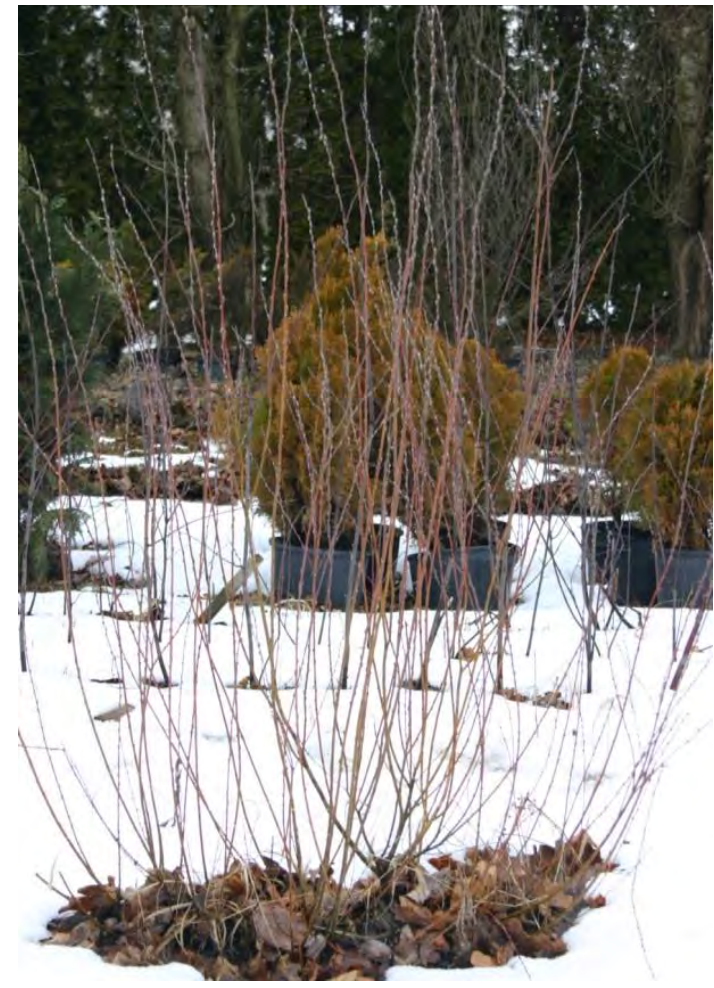

29. ábra: S. rosmarinifolia RO1 klón barkás vesszőkkel március 10-én (fotó: Treerné, 2006) 
6. táblázat: $S$. rosmarinifolia RO1 klón vesszőhozama, méretkategóriái és ezek \%-os megoszlása 2006-2013

\begin{tabular}{|c|c|c|c|c|c|c|c|}
\hline \multirow{2}{*}{ Vessző hossza (cm) } & \multirow{2}{*}{ Kategória } & \multicolumn{7}{|c|}{ Kategóriák megoszlása (\%) } \\
\cline { 3 - 8 } & & 2006 & 2008 & 2010 & 2011 & 2012 & 2013 \\
\hline $90-120$ & Extra & 30 & 76 & 62 & 58 & 49 & 42 \\
\hline $60-90$ & I. o. & 36 & 16 & 20 & 42 & 21 & 58 \\
\hline $40-60$ & II. o. & 18 & 5 & 18 & 0 & 26 & 0 \\
\hline $20-40$ & III. o. & 16 & 3 & 0 & 0 & 4 & 0 \\
\hline \multicolumn{2}{|c|}{ Átlagos vesszőhozam (db/tö) } & 24,5 & 56,7 & 117,6 & 66,7 & 100,1 & 92,5 \\
\hline
\end{tabular}

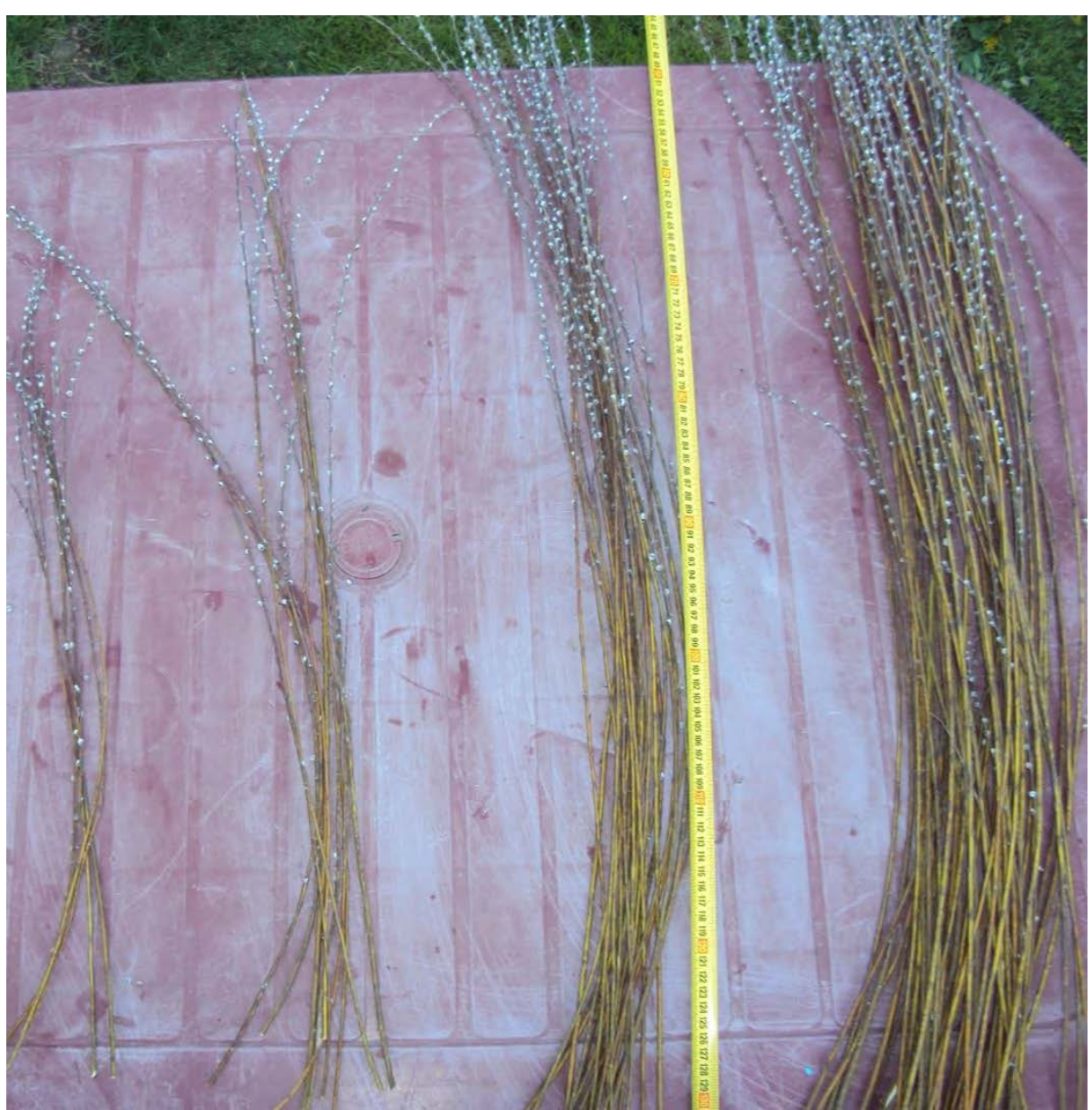

30. ábra: S. rosmarinifolia RO1 barkás vesszői méret-kategóriák szerint (fotó: Treerné, 2011)

Legnagyobb arányban a négy éves tövek hoztak Extra méretű vesszőket, innentől ezek aránya folyamatosan csökkent (31. ábra - következő oldal teteje). 


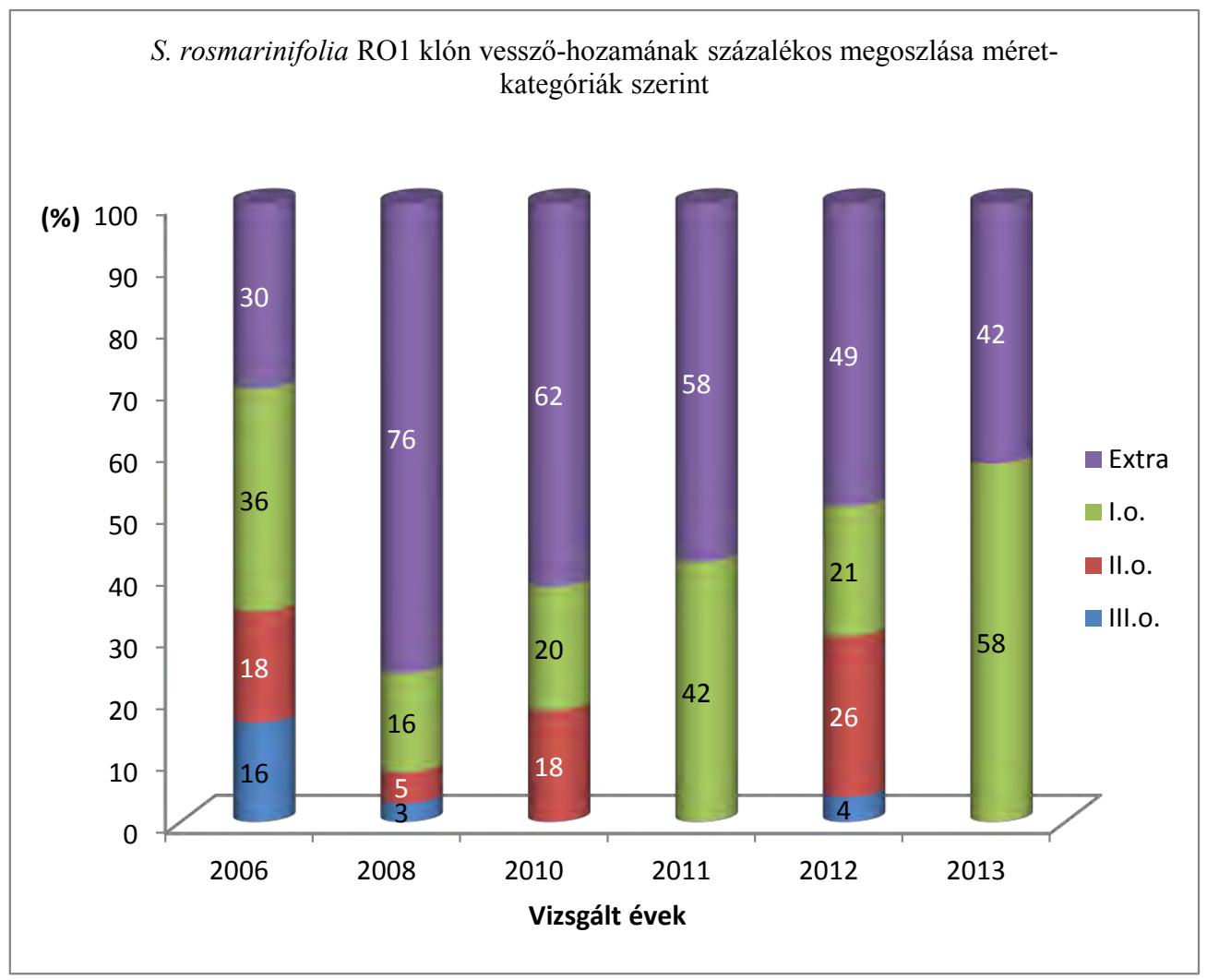

31. ábra: S. rosmarinifolia RO1 klón vesszőinek százalékos megoszlása méret-kategóriák szerint (2006-2013)

A konténerbe kiültetett anyanövénynél megfigyelhető volt az RO2 klón gyökérrendszerétől erősen eltérő gyökérfejlődés. Míg a S. rosmarinifolia RO2 gyökerei sekélyen hálózták be a földet, ennél a klónnál a gyökerek oldalirányban kevésbé, sokkal inkább függőlegesen lefelé fejlődtek, a konténer alján keresztülnőve mélyen belegyökereztek a faiskola talajába.

\subsubsection{Salix rosmarinifolia RO2 klón}

Apró barkás vesszőit Tapolca környékén gyüjtötték. Fantázianeve alacsony, oldalirányban növekedő, legyökerező szárú habitusára és az élénkzöld vesszőszínre utal. Oldalirányba növő, majd felfelé törő vesszői rövid (néhány mm-es) szártagokból állnak.

A 2004-es szabadföldi dugványozáskor az eredés 20,6\%-os volt. A dugványozás évében 40-70 cm hosszú, elhajló vesszőket hozott. A második évben a $60-80 \mathrm{~cm}$ es hajtások - annak ellenére, hogy néhány vesszőt meghagytam a tövön - újra alulról törtek elö. A dugványozást követő második év-

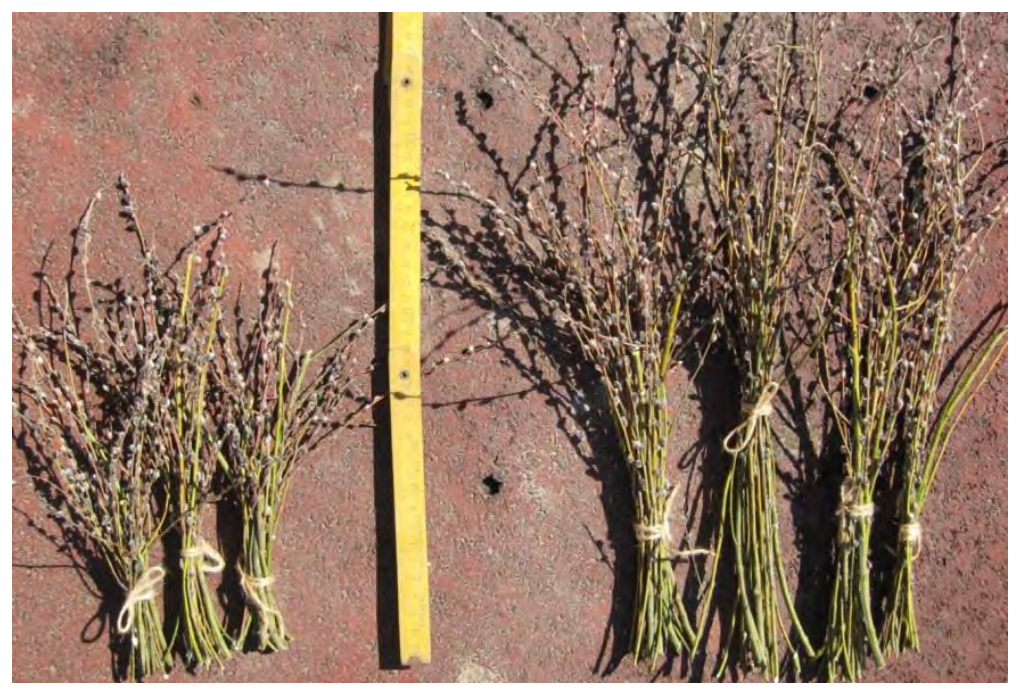

32. ábra: S. rosmarinifolia RO2 klón rövid barkás vesszői (fotó: Treerné, 2006) 
ben a tövekröl átlagosan 40,5 db, többségében 30-40 cm-es barkás vesszőt szedtem. Ezek a veszszők a hosszabb, elágazódó, bokros gallyak, vesszők feldarabolásával jöttek létre oly módon, hogy a többéves, illetve vastagabb részekről az elágazódások tövénél levágtam az egyes vékony, többet már el nem ágazódó vesszőket (32. ábra, 1. előző oldal alja). Extra hosszú méretü és bokros áru nem termett ezen a klónon. A háromféle hosszúságú vesszők százalékos megoszlása a 24 éves növényeken közel azonos volt, legnagyobb arányban (46\%) 2011-ben fejlödtek I. osztályú vesszők (33. ábra). A vesszőhozam a növények két éves korától hat éven keresztül tendenciózusan csökkent (7. táblázat).

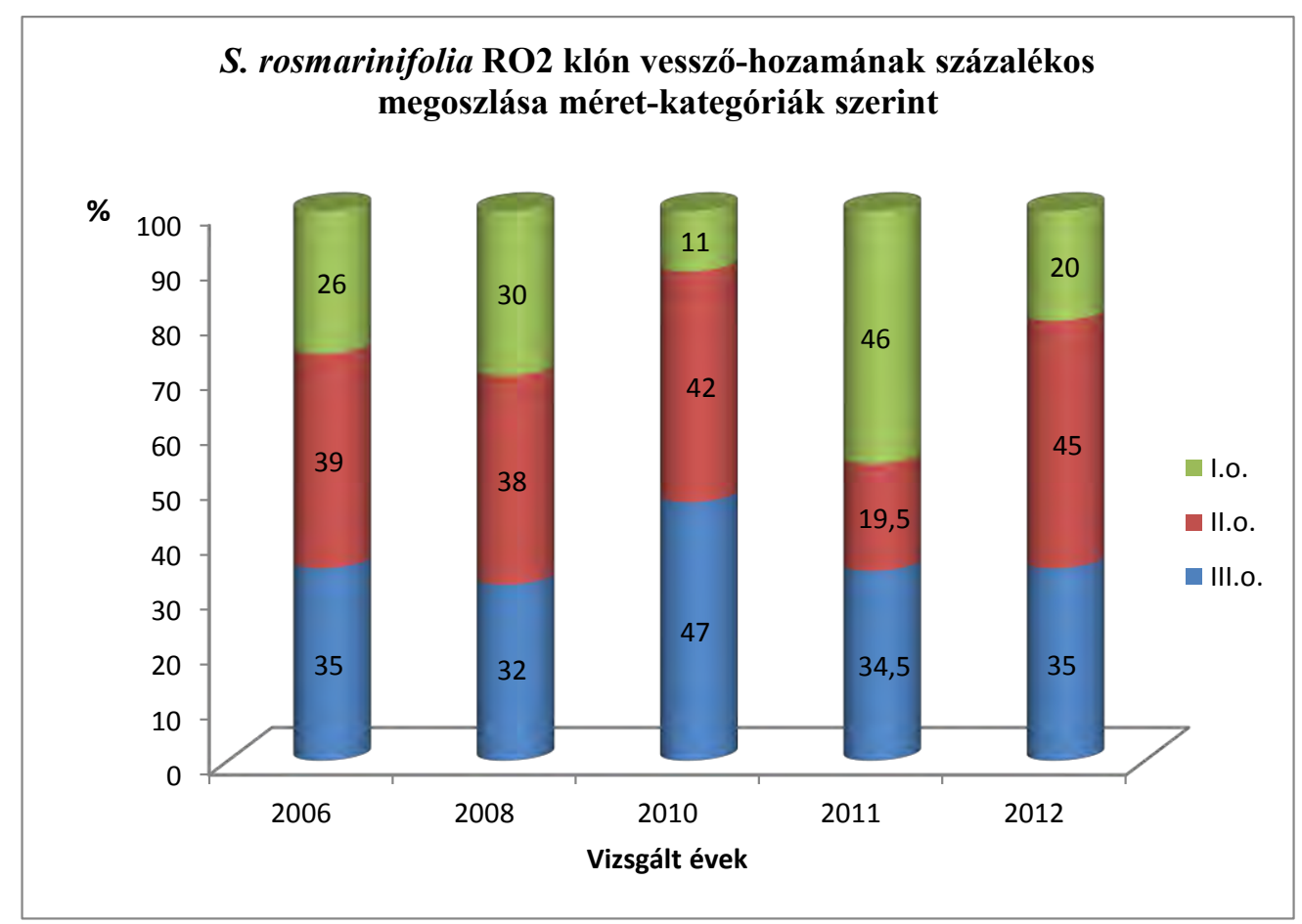

33. ábra: S. rosmarinifolia RO2 klón vesszőinek százalékos megoszlása méret-kategóriák szerint (2006-2012)

7. táblázat: S. rosmarinifolia RO2 klón vesszőhozama, méretkategóriái és ezek \%-os megoszlása 2006-2012

\begin{tabular}{|c|c|c|c|c|c|c|}
\hline \multirow{2}{*}{ Vessző hossza (cm) } & \multirow{2}{*}{ Kategória } & \multicolumn{5}{|c|}{ Kategóriák megoszlása (\%) } \\
\cline { 3 - 7 } & & 2006 & 2008 & 2010 & 2011 & 2012 \\
\hline $40-60$ & I. o. & 26 & 30 & 11 & 46 & 20 \\
\hline $25-40$ & II. o. & 39 & 38 & 42 & 19,5 & 45 \\
\hline $15-25$ & III. o. & 35 & 32 & 47 & 34,5 & 35 \\
\hline \multicolumn{2}{|c|}{ Átlagos vesszőhozam (db/tö) } & $\mathbf{4 0 , 5}$ & $\mathbf{3 7 , 8}$ & $\mathbf{3 1 , 4}$ & $\mathbf{1 8 , 9}$ & $\mathbf{2 8 , 3}$ \\
\hline
\end{tabular}

A konténerbe kiültetett anyanövény esetében megfigyelhető volt a gyökerek hajtásokhoz hasonló, föleg oldalirányú növekedése: a konténer alsó résein áttörve nem a talajba lefelé nőttek, hanem a talajfelszín közelében vízszintes irányban hálózták be a tövek környezetét. Az alacsonyan kúszó és legyökerező hajtások, az ehhez hasonló gyökérrendszer, és a többi $S$. rosmarinifolia klónnál 7-10 nappal később megpattanó hajtásrügyei arra utalnak, hogy ez a klón a többitől erősen eltérő genotípus. 


\subsubsection{Salix rosmarinifolia RO3 klón}

Narancspiros vesszőit Veszprém környékén gyüjtötték, fajtársai között magas termetünek számít (34. ábra). Kezdetben zöld vesszői a tél folyamán élénk narancspirosra színeződnek.

A dugványozást követő harmadik évtől tövenként átlagosan 13,9 db 80-90 cm hosszú vesszőt hozott. A szaporítást követő negyedik évben (2010-ben) az előző évi visszavágás után $150 \mathrm{~cm}$ magas bokorrá

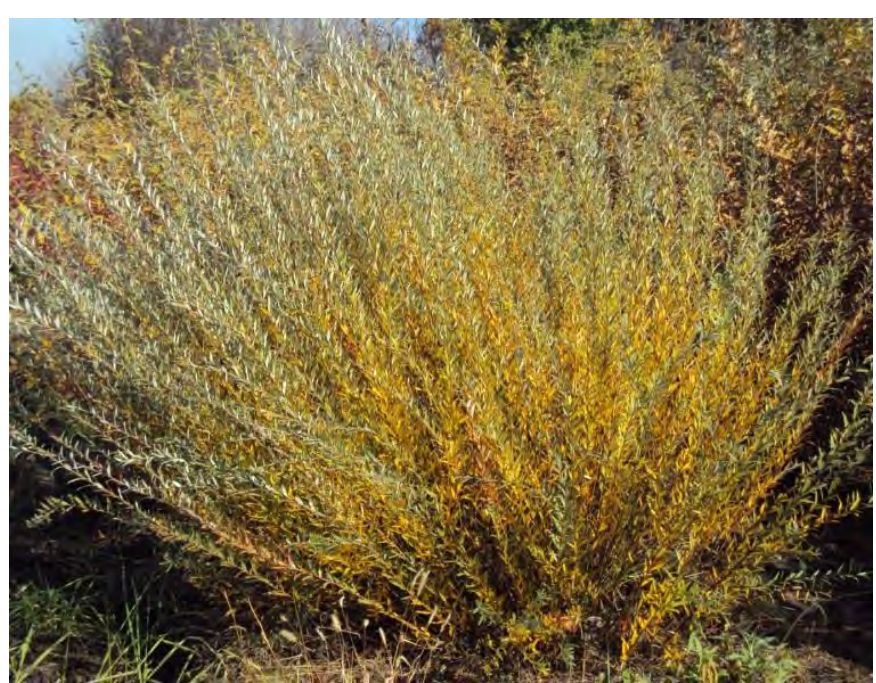

34. ábra: S. rosmarinifolia RO3 klón október végén (fotó: Treerné, 2010) fejlődött. A klónról szedhető vesszők évenkénti átlagos hozama a vizsgált években folyamatosan nőtt (8. táblázat).

8. táblázat: $S$. rosmarinifolia RO3 klón vesszőhozama, méretkategóriái és ezek \%-os megoszlása (2008-2011)

\begin{tabular}{|c|c|c|c|c|}
\hline \multirow{2}{*}{ Vessző hossza (cm) } & \multirow{2}{*}{ Kategória } & \multicolumn{3}{|c|}{ Kategóriák megoszlása (\%) } \\
\cline { 3 - 5 } & & 2008 & 2010 & 2011 \\
\hline $120-160$ & Extra & 0 & 7 & 51 \\
\hline $90-120$ & I. o. & 0 & 39 & 29 \\
\hline $60-90$ & II. o. & 24 & 54 & 12 \\
\hline $40-60$ & III. o. & 76 & 0 & 8 \\
\hline \multicolumn{2}{|l}{ Átlagos vesszöhozam (db/tö) } & $\mathbf{1 3 , 9}$ & $\mathbf{3 7 , 3}$ & $\mathbf{4 9 , 9}$ \\
\hline
\end{tabular}

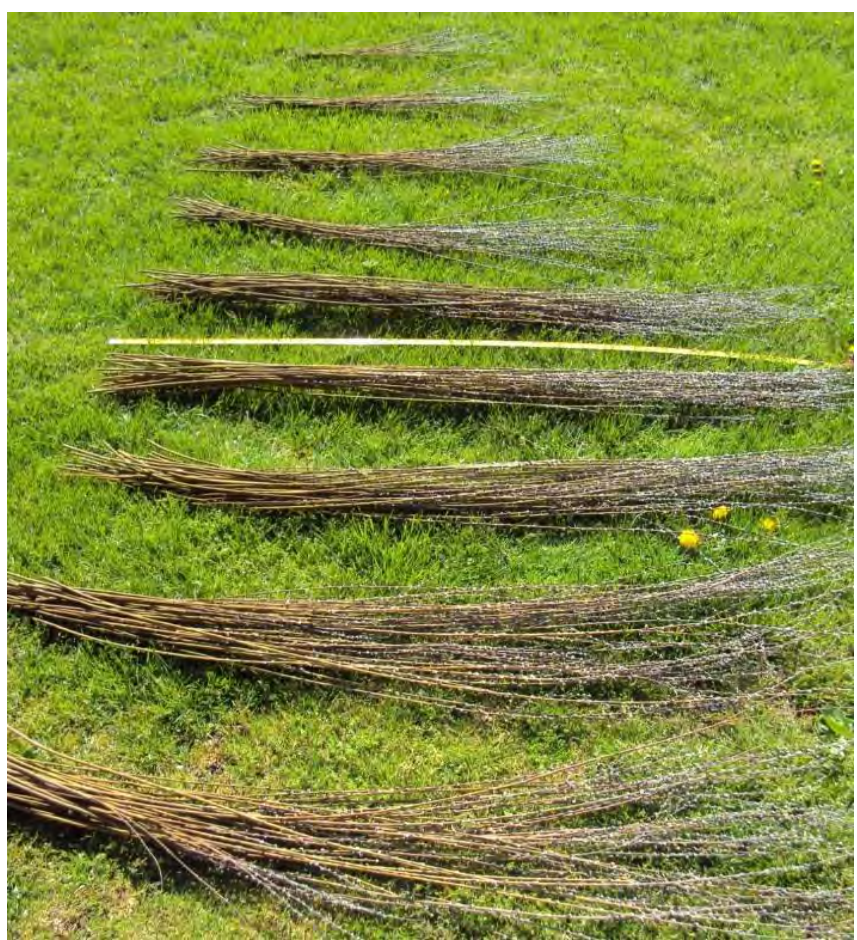

35. ábra: S. rosmarinifolia $\mathrm{RO3}$ méret szerint válogatott barkás vesszői (fotó: Treerné, 2011)
A méret-kategóriák (35. ábra) százalékos megoszlása is kedvezően alakult: a két éves töveken csak II. és III. osztályú veszszők fejlődtek, a dugványozást követő ötödik évben a fejlődött vesszők 51\%-a extra méretű (120-160 cm hosszú) volt (36. ábra következő oldal teteje). 


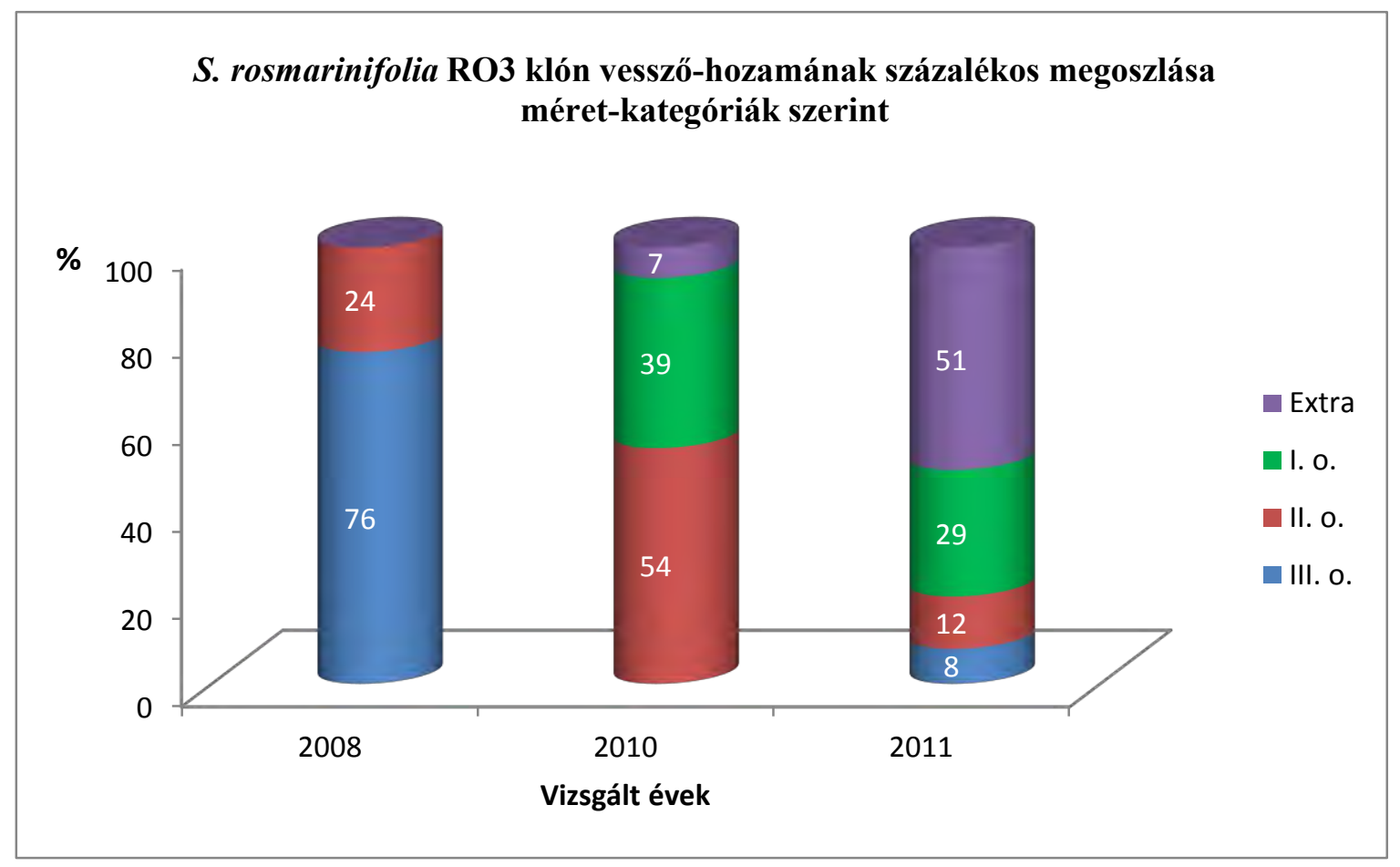

36. ábra: $S$. rosmarinifolia $\mathrm{RO3}$ klón vesszőinek százalékos megoszlása méret-kategóriák szerint (2008-2011)

\subsubsection{Salix rosmarinifolia RO4 klón}

Ez a klón is felálló habitusú, vesszőszíne bordópiros, mely a konténerben nevelt növényeken fóliasátor alatt nem alakult ki, ott szürkésbarna árnyalatú maradt. A vesszők a téli hónapok alatt színeződtek. A szeptemberben még zöld színű hajtásokon, csak a virágzati rügyek rügypikkelye utalt a vesszők tél végi színére (37. ábra).

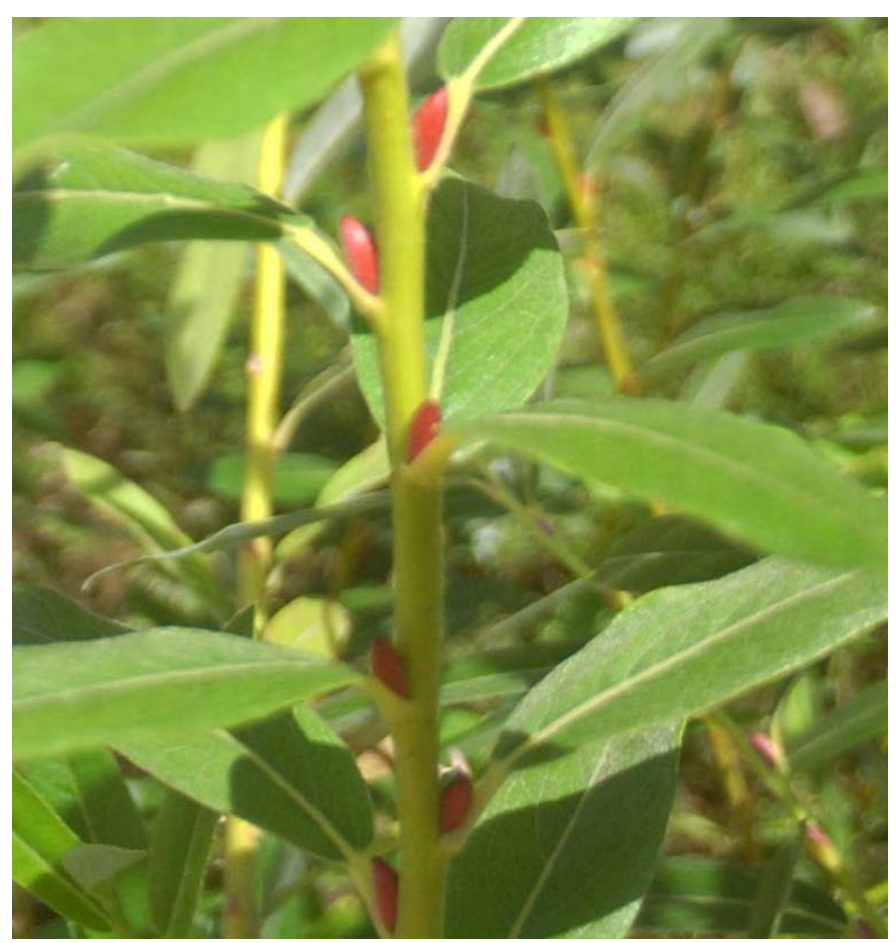

37. ábra: S. rosmarinifolia RO4 klón bordó virágzati rügyei szeptemberben (fotó: Treerné, 2013) 
Tövenkénti átlagos vesszőhozama 2013-ban 83,7 volt, megközelítette a klónok közül legtöbb vesszőt produkáló RO1 klón vesszőhozamát. A klónról szedhető vesszők méret-kategóriáit, és ezek százalékos megoszlását a 9. táblázat tartalmazza.
9. táblázat: $S$. rosmarinifolia RO4 klón vesszőinek \%-os megoszlása méret-kategóriák szerint 2013-ban

\begin{tabular}{|c|c|c|}
\hline Vessző hossza (cm) & Kategória & $\begin{array}{c}\text { Kategóriák meg- } \\
\text { oszlása (\%) }\end{array}$ \\
\hline $120-150$ & Extra & 8 \\
\hline $90-120$ & I. o. & 45 \\
\hline $60-90$ & II. o. & 47 \\
\hline
\end{tabular}

A 2008. február 21-én végzett dugványozást követően már egy hét múlva megpattantak a hajtásrügyek, és 27 dugvány kihajtott. Az 1,2 mm átmérőjü dugványok kihajtottak ugyan, de nem gyökeresedtek. Az 1,6 és 3 mm közötti átmérőjü dugványokon egy-egy szál vékony gyökér fejlődött. A 3 mm-nél vastagabb átmérőjü dugványokon kivétel nélkül sürü, elágazódó gyökérzet

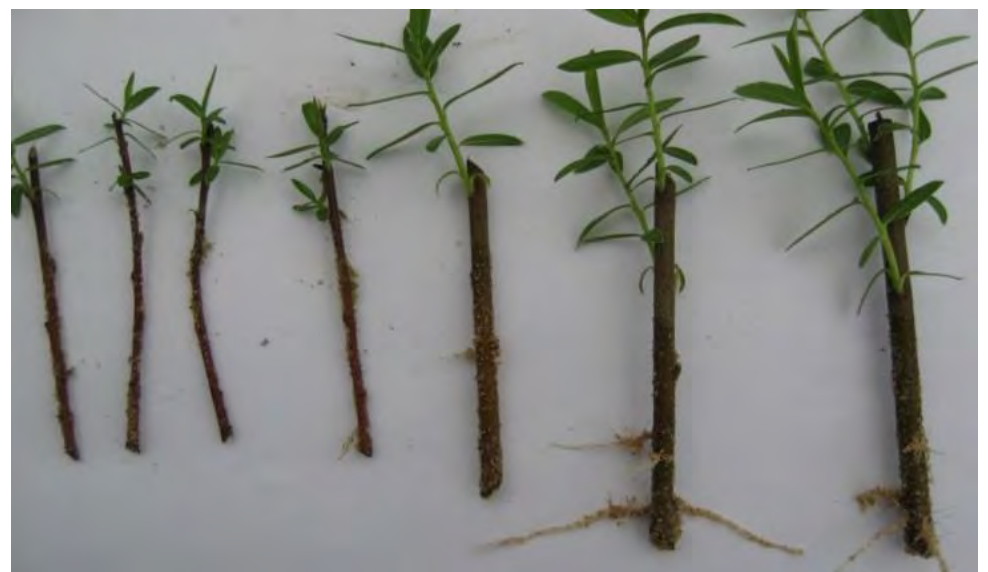

38. ábra: $S$. rosmarinifolia RO4 dugványok gyökeresedése (fotó: Treerné, 2008) fejlödött (38. ábra). A becserepezéskor megfigyelt gyökeresedés és a dugványok mért átmérője alapján függetlenségvizsgálattal megállapítottam, hogy 99\%-os szignifikancia szinten is összefügg a gyökeresedés mértéke a dugvány átmérőjével, a vastagabb dugványok jobban gyökeresedtek.

\subsection{A melegtalp kezelés, a gyökereztető szerek és a dugványozás időpontjának hatása a gyökeresedésre}

A háromtényezős kísérlet részletes eredményeit (szöveges jegyzőkönyvét) az M9. melléklet (158. o.) tartalmazza. Az alábbiakban a három vizsgált tényező hatásait emelem ki röviden. Az eredmények rendszeres értékelése közben készített fotók dokumentációját az M10. melléklet (175. o.) tartalmazza. 


\subsubsection{Salix caprea CA1 klón gyökereztetésének eredményei}

\subsubsection{A melegtalp kezelés hatása a gyökeresedésre}

A melegtalp kezelés hatása minden esetben gyorsította a dugványok életfolyamatait, de nem mindig volt kedvező hatása a gyökeresedésre. Legkiugróbb különbséget mindkét taxonnál a decemberi dugványozás esetében kaptam. Ekkor a melegtalpon lévő növények többségénél valamilyen folyamat (kalluszképződés, gyökeresedés, kihajtás) a dugványozást követő második héten megindult, melegtalp kezelés nélkül a dugványok legalább három hétig nyugalomban maradtak. Melegtalp nélkül a decemberben szedett dugványok esetében öt hét alatt sem fejlődtek gyökerek, csak két-három kalluszcsomó törte át a héjat a dugványok alján. A novemberben és a januárban szedett dugványok is korábban reagáltak a kezelésekre a decemberiekkel összehasonlítva. A képződött kalluszból melegtalp nélkül 21 nap,

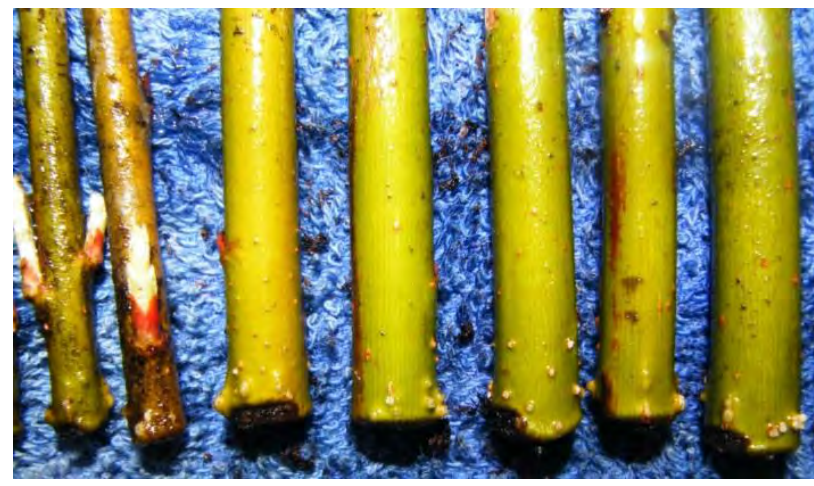

39. ábra: Novemberi S. caprea dugványok (melegtalp nélkül, Ke1/2 kezeléssel) 2 héttel a dugványozást követôen (fotó: Treerné, 2010) melegtalpon már 7 nap múlva megkezdődött a járulékos gyökerek differenciálódása. A novemberben szedett és melegtalpon gyökereztetett összes $S$. caprea dugvány kihajtott a második héten. A közeg fölött 4-6-8 cm-es, 6 leveles hajtások, a föld alá került rügyekből 4-6 cm-es fehér etiolálódott hajtások fejlődtek. A kontroll dugványok melegtalpon és melegtalp nélküli gyökereztetésének eredményeit az M12. melléklet tartalmazza (183. o.).

\subsubsection{Gyökereztető szerek hatása a gyökeresedésre}

A fél órán keresztül történő Kelpak ${ }^{\circledR}$-os felszívatás következtében leghamarabb (8 nap után) a januári dugványok kalluszosodtak, és kezdtek hajtani; majd a novemberiek (14 nap, 39. ábra), végül a decemberiek (5 hét). Novemberben ez a kezelés eredményezte a legnagyobb (96\%) arányú gyökeresedést. A biostimulátorral 8 órán keresztül végzett felszívatás a januárban szedett, melegtalpon gyökereztetett dugványok esetében fejtette ki a legjobb hatást, 14 nap elteltével dugványonként legalább $5 \mathrm{db}$, átlagosan $9 \mathrm{~mm}$ hosszú gyökér képződött. A Kelpak ${ }^{\circledR}-k a l$ kezelt dugványok gyökereztetésének eredményeit az M13. melléklet tartalmazza (184. o.).

A naftil-ecetsavval oldat formájában kezelt dugványok teljes földbe érő részükön elkezdtek gyökeresedni, leghamarabb (7 nap elteltével) a novemberben szedett, melegtalp nélkül gyökereztetett dugványok. Két héttel a kezeléseket követően a $S$. caprea melegtalp nélkül gyökereztetett dugványai közül a NES oldattal végzett kezelés eredményezte a legerőteljesebb kallusz- 
képződést és gyökeresedést. A dugványok talpi része erősen megvastagodott, de három hét elteltével melegtalpon a legtöbb NES oldattal kezelt dugvány pusztulásnak indult, alulról felfelé megbarnult. A túlzott kalluszosodás, a parenchima sejtek ilyen mértékü burjánzása már nem volt pozitív hatással a gyökeresedésre. A naftilecetsavval por formában kezelt dugványoknak föleg az alsó részén képződtek gyökerek. Melegtalp nélkül ez utóbbi kezelés eredményezte a legnagyobb arányú (88\%) gyökeresedést a decemberi dugványok esetében (40. ábra). A 6\%o-es naftilecetsavval alkoholos oldat és por formátumban kezelt dugványok gyökereztetésének eredményeit az M14. melléklet tartalmazza (185. o.).

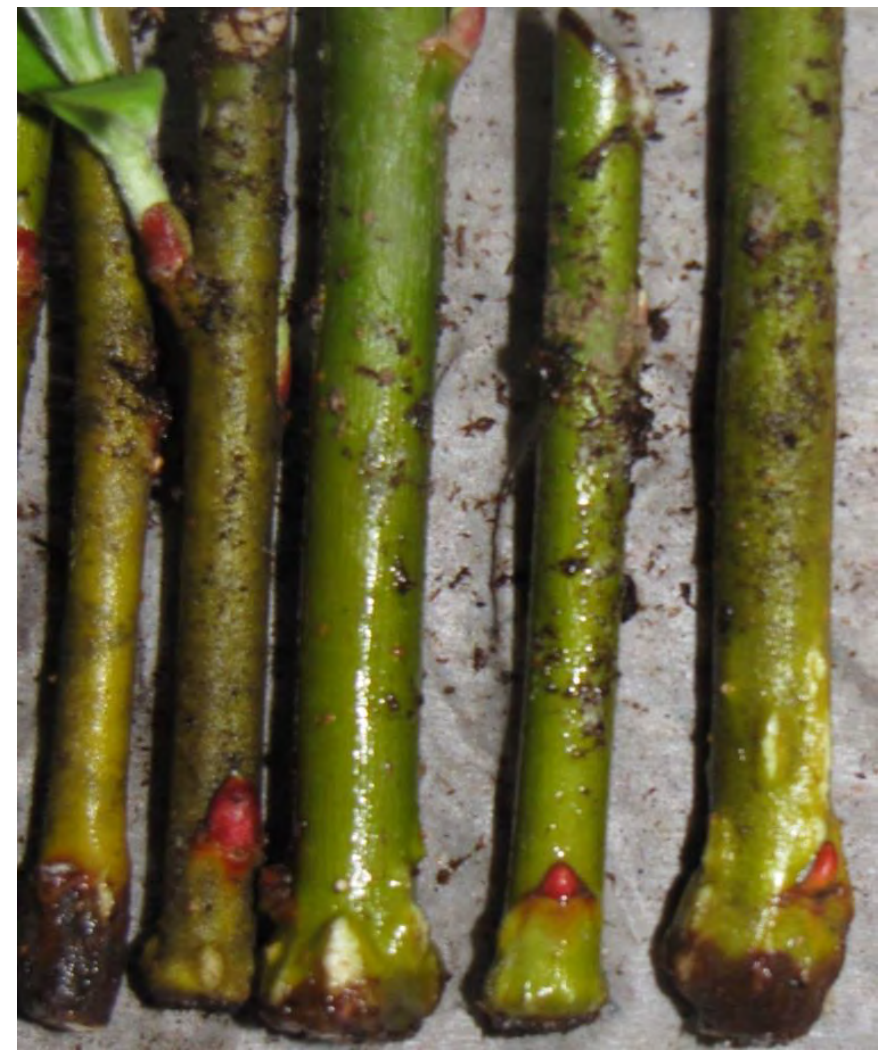

40. ábra: Kalluszképződés NES porral kezelt, decemberben szedett $S$. caprea dugványok talpi részén melegtalp nélkül gyökereztetve, a dugványozást követően 5 héttel

(fotó: Treerné, 2010)

\subsubsection{A dugványszedés és a gyökereztetés időpontjának hatása a gyökeresedésre}

A novemberben, melegtalp nélkül gyökereztetett $S$. caprea dugványok esetében nyolc héttel a kezelések után a naftil-ecetsav talcumpor formájában alkalmazva bizonyult legjobbnak a gyökeresedés elösegítésére. Nyolc héttel a kezelés után dugványonként $5 \mathrm{db} 25 \mathrm{~mm}$ hosszú gyökér fejlődött. Szintén jól gyökeresedtek a Kelpak ${ }^{\circledR}$-kal fél órán keresztül felszívatott dugványok, melyek több mint 60\%-án 3-6 db 5-10 mm hosszú gyökér fejlödött három hét alatt. Hosszútávon a gyökeresedés Kelpak ${ }^{\circledR}$-kal végzett felszívatás következtében volt a legjobb, melegtalp alkalmazása nélkül. A fél órás felszívatás $96 \%$-os, nyolc órás felszívatás $83 \%$-os gyökeresedést eredményezett, de ez utóbbi esetben volt a legnagyobb (52\%) a gyökerekkel teljesen átszött földlabdájú dugványok aránya.

A decemberi dugványok gyökeresedése indult meg a lekésőbb a másik két szedési idöponthoz képest. A gyökeresedésre legjobb hatással a Kelpak ${ }^{\circledR}$-kal végzett 8 órás felszívatás volt melegtalppal kombinálva. A kezelés hatására a dugványok többségénél dugványonként több mint $5 \mathrm{db}$, átlagosan $5 \mathrm{~mm}$ hosszú gyökér fejlödött a kezelést követően 21 napra. Melegtalp hatása nélkül a decemberben szedett dugványok esetében legalább 5 héten keresztül nem indult meg 
a gyökerek fejlödése. A kísérlet befejezését követő bonitálás során a melegtalp nélkül gyökereztetett, decemberben szedett $S$. caprea dugványok közül a kontroll gyökeresedett legjobban.

Januárban a NES por formátummal végzett kezelés bizonyult legjobbnak a gyökeresedés elősegítésére. Az eredmények hasonlóak voltak a kontroll esetében tapasztaltakhoz, azzal a különbséggel, hogy a naftil-ecetsavval kezelt dugványokon kevesebb, de differenciáltabb kalluszcsomó fejlődött, és a dugványok aljánál is erőteljesebb volt a kalluszképződés.

A különböző hónapokban végzett gyökereztetési kísérletek végső kiértékelésekor kapott eredményeket az M11. mellékletben (182. o.) szereplő bonitálási táblázatok tartalmazzák.

\subsubsection{Salix rosmarinifolia R03 klón gyökereztetésének eredményei}

\subsubsection{A melegtalp kezelés hatása a gyökeresedésre}

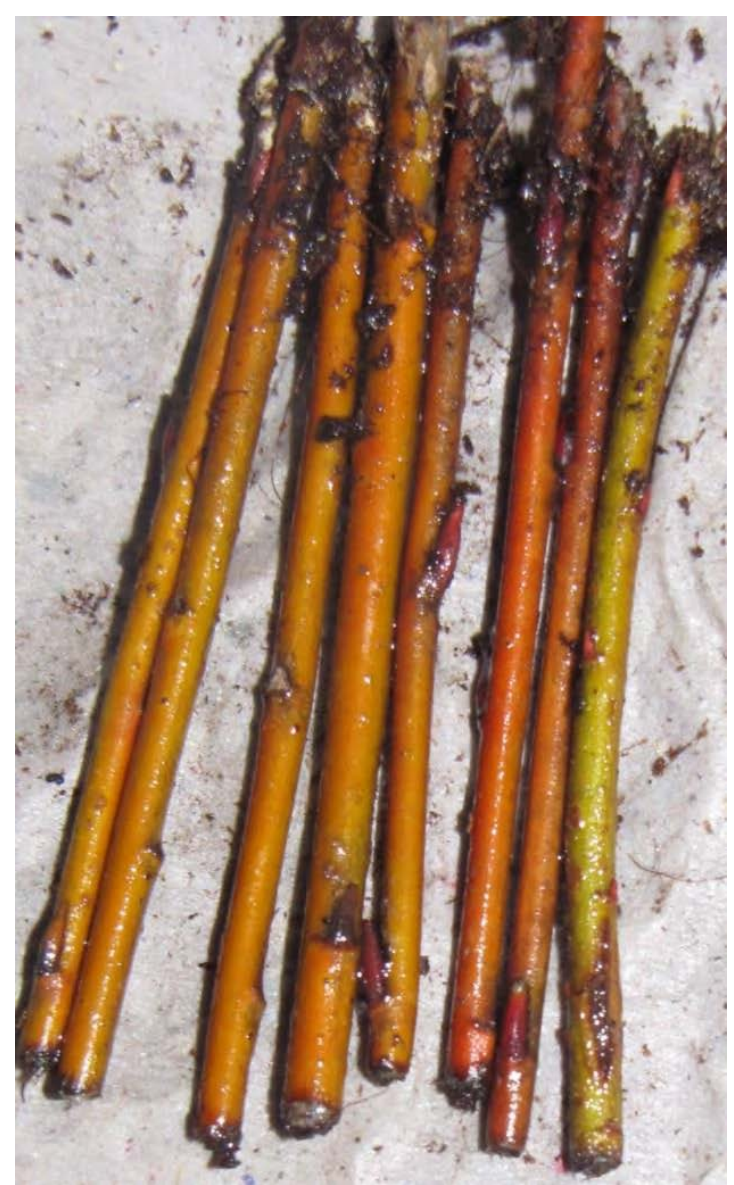

41. ábra: Élő, de még nem gyökeresedő, NES porral kezelt, decemberben szedett $S$. rosmarinifolia dugványok melegtalp nélkül, 5 héttel a dugványozást követően (fotó: Treerné, 2010)

A dugványokon a járulékos gyökerek képződése a kezelések hatására is csak lassan, vontatottan indult meg. Melegtalpon a dugványok könnyen kiszáradtak, elpusztultak. Melegtalp nélküli kezeléseknél a héj egészséges színe arra utalt, hogy a dugványok élnek, de gyökerek hosszú ideig (3-5-8 hétig) nem fejlődtek (41. ábra). A kontroll dugványok melegtalpon és melegtalp nélküli gyökereztetésének eredményeit az M15. melléklet tartalmazza (186. o.).

\subsubsection{Gyökereztetố szerek hatása a gyökeresedésre}

A Kelpak ${ }^{\circledR}-k a l$ végzett fél órás kezelés hatására a legtöbb kalluszcsomó és gyökérkezdemény melegtalpon a januárban szedett dugványokon fejlödött. Gyökérképződést csak a melegtalp nélkül gyökereztetett novemberi (21 nap múlva 1-2 db átlagosan 20 mm-es gyökér) és a januári (21 nap múlva 1-2 db átlagosan $5 \mathrm{~mm}$ hosszú gyökér) dugványokon tapasztaltam. Ez utóbbi bizonyult hosszútávon a legjobb kezelésnek. A 8 órás kezelés a januárban szedett, melegtalpon gyökereztett dugványok esetében bizonyult legeredményesebbnek négy hét elteltével, a dugványok 27\%-ánál kalluszcsomók jelentek meg, 15\%-uk esetében 3-4db, 2-3 mm-es gyökér fejlödött 21 nap elteltével, a többi dugványon nem indult meg gyökerek képződése. 
Hosszútávon a Kelpak $^{\circledR}$-kal való 8 órás felszívatás bizonyult minden dugványozási időpontban a második leghatékonyabb kezelésnek a gyökeresedés elősegítésére. A Kelpak ${ }^{\circledR}$ kal kezelt dugványok gyökereztetésének eredményeit az M16. melléklet tartalmazza (187. o.).

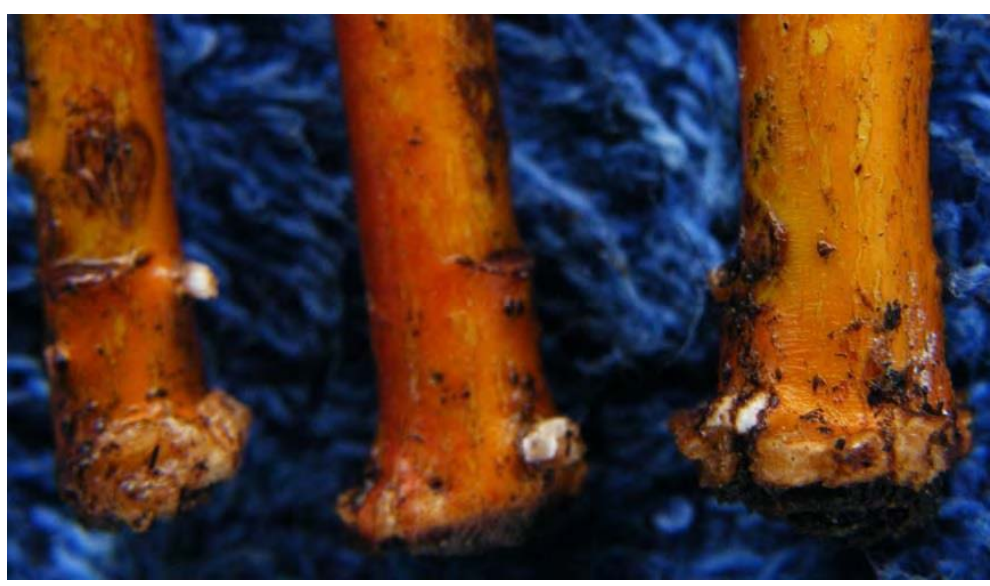

42. ábra: Novemberi $S$. rosmarinifolia dugványok (melegtalpon, NES porral kezelve) 3 héttel a dugványozást követően (fotó: Treerné, 2009)

A naftilecetsavval oldat formájában végzett kezelés csak melegtalpon hatott erőteljesen a dugványokra, melyeknél intenzív kalluszképződést indukált. Melegtalp nélkül a novemberben szedett dugványok 6\%-ánál fejlődtek 10-15 mm-es gyökerek (1-2 db/dugvány, 8 hét elteltével), a többi időpontban nem tapasztaltam gyökérképződést az első nyolc héten. Melegtalpon a kezelés hatására a dugványok jelentős százaléka elpusztult. Alkalmasabbnak bizonyult a hormon alkalmazása por formájában, ekkor sokkal kisebb arányban pusztultak el dugványok. A NES porral végzett kezelés hatására gyökerek fejlődése az első öt héten csak a novemberi dugványok esetében történt (42. ábra), a másik két időpontban szedett dugványokon legfeljebb kalluszképződést tapasztaltam. Hosszútávon a novemberben és a decemberben szedett dugványok esetében melegtalp nélkül ez a kezelés bizonyult legjobbnak a gyökeresedés szempontjából. A 6\%-es naftil-ecetsavval alkoholos oldat és por formátumban kezelt dugványok gyökereztetésének eredményeit az M17. melléklet tartalmazza (188. o.).

\subsubsection{A dugványszedés és a gyökereztetés időpontjának hatása a gyökeresedésre}

A novemberben szedett $S$. rosmarinifolia dugványok gyökeresedése NES por formában végzett kezelést követöen melegtalp nélkül volt a legjobb ( 8 hét, 1-2 db 10 mm-es gyökér/dugvány). Második leghatékonyabb kezelés a Kelpak ${ }^{\circledR}$-kal 8 órán keresztül végzett gyökereztetés volt szintén melegtalp nélkül (43. ábra - következö oldal teteje). 


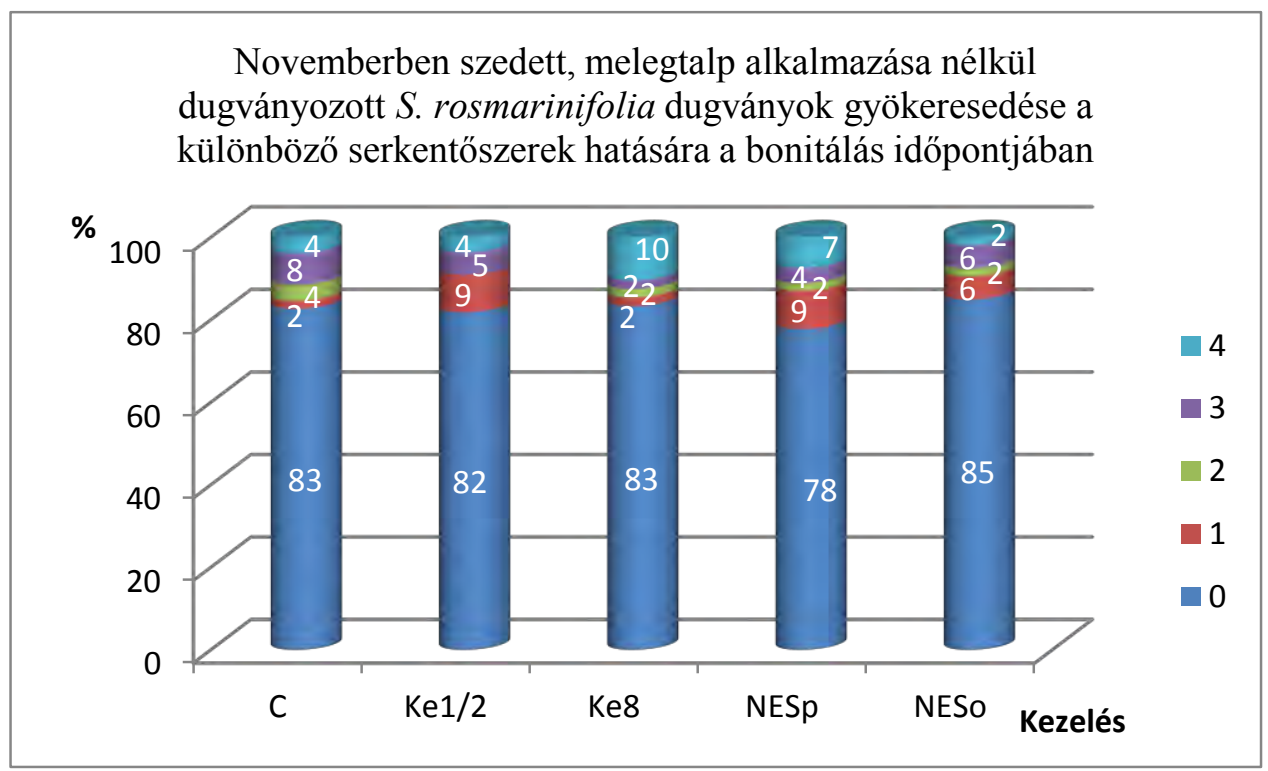

43. ábra: Novemberi $S$. rosmarinifolia dugványok gyökeresedése bonitáláskor

A decemberi dugványok gyökeresedése indult meg legkésőbb a másik két szedési időponthoz képest. A dugványok a novemberiekhez hasonlóan a NES porral végzett kezelésre reagáltak a legjobban, csak a gyökerek fejlödése lassabban indult meg, 13 hét elteltével fejlödött dugványonként 1-2 db 10 mm-es gyökér. Második legjobb hatása a Kelpak ${ }^{\circledR}-k a l$ végzett 8 órás felszívatásnak volt a gyökeresedésre, melegtalp nélkül (44. ábra).

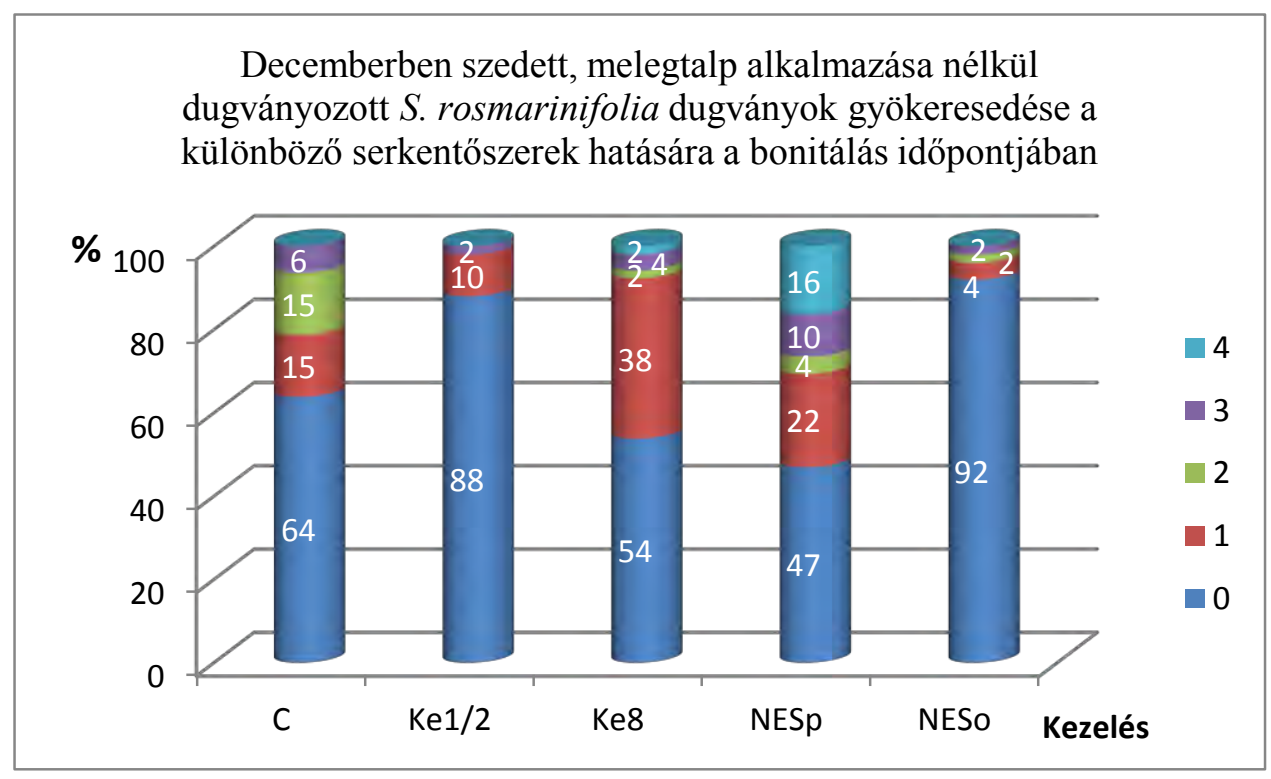

44. ábra: Decemberi $S$. rosmarinifolia dugványok gyökeresedése bonitáláskor

A januárban szedett $S$. rosmarinifolia dugványok kezelései közül a Kelpak ${ }^{\circledR}-k a l$ fél órán keresztül végzett felszívatást követően, melegtalp nélküli gyökereztetés bizonyult legjobb hatásúnak a gyökeresedésre, ekkor a dugványok 38\%-a meggyökeresedett (45. ábra - következő oldal teteje). 


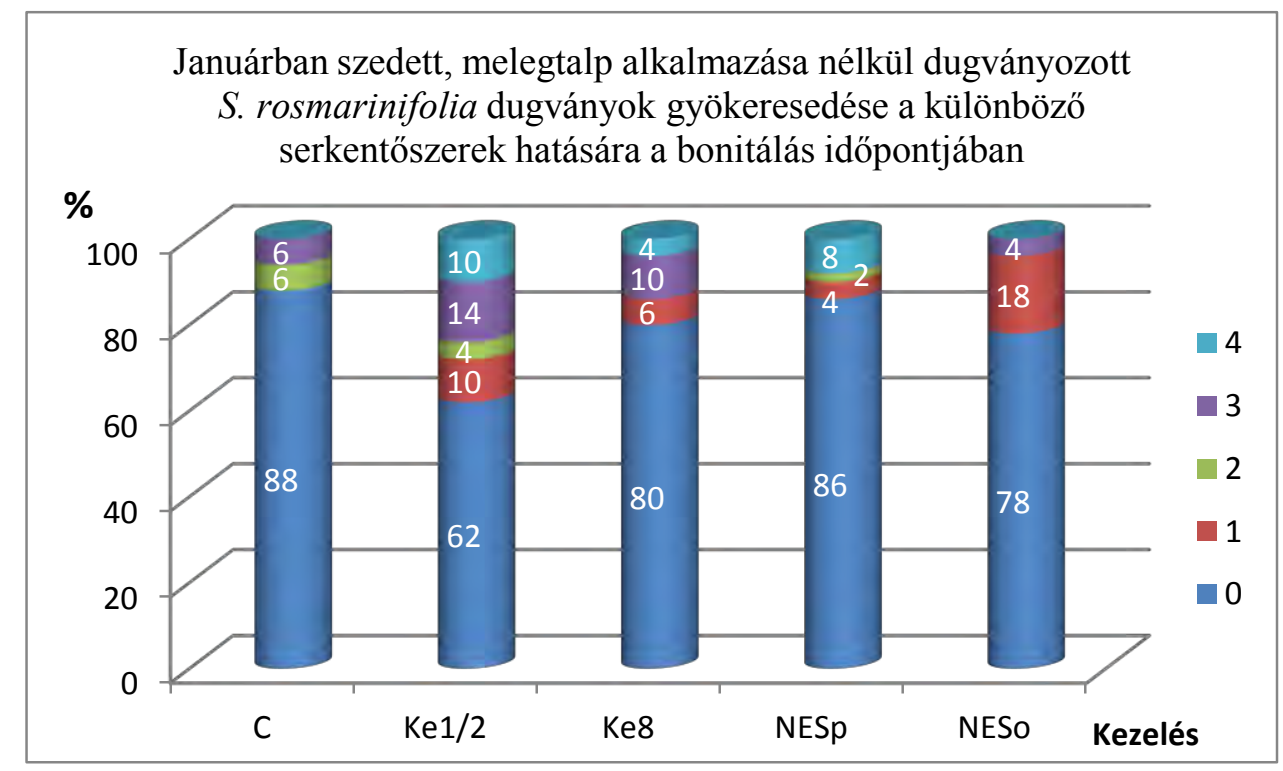

45. ábra: Januári $S$. rosmarinifolia dugványok gyökeresedése bonitáláskor

A különböző hónapokban végzett gyökereztetési kísérletek végső kiértékelésekor kapott eredményeket az M11. mellékletben (182. o.) szereplő bonitálási táblázatok tartalmazzák.

\subsection{Salix fajok károsítói és más minőségrontó tényezői}

\subsubsection{Kórokozók}

A szakirodalomban említett kórokozók közül a következöket figyeltem, illetve határoztam meg az általam szaporított klónokon, illetve az általam vizsgált ültetvényekben, élöhelyeken: Erysiphe adunca, Drepanopeziza sphaeroidea, Melampsora sp., Phellinus igniarius.

A szakirodalomban kifejezetten a kecskefüz kórokozójaként számon tartott lisztharmat (Erysiphe adunca) megjelent ugyan néhány Soroksáron szaporított anyanövényen ( $S$. caprea CA1 klónon), de a betegség nem okozott olyan súlyos tüneteket, mely a későbbiekben a vesszők értékét csökkentette volna.

A füz fajok közül a $S$. caprea nagyon fogékony a rozsdára (Melampsora sp.), számos olyan egyedet találtam, melynek minden levelén jelen voltak az uredotelepek. A nemzetséget egy kecskefüz leveléből készített metszeten mikroszkópos megfigyeléssel is azonosítottam. Ez a betegség azonban nem gyengítette le a növényeket, és a vágott barkák minőségére sem volt negatív hatással a soroksári ültetvényben. Nem volt jellemző az irodalomban leírt növekedés-kiesés; tapasztalataim szerint a fejlődő hajtások, későbbi vesszők számát sem befolyásolta. $S$. x smithiana példányainak levelein is megtaláltam, ettől függetlenül a növények erős, egészséges hajtásokat hoztak. 


\begin{abstract}
A füzfa hajtáselhalását is okozó Drepanopeziza sphaeroidea (f. acerv. Marssonina salicicola) kórképét, az apró, barnásfekete szegélyü, halványabb barna közepű foltokat a levéllemezek színén egyaránt megfigyeltem a $S$. caprea, a $S$. purpurea, és a $S$. rosmarinifolia fajokon. A tünetek a $S$. caprea és $S$.

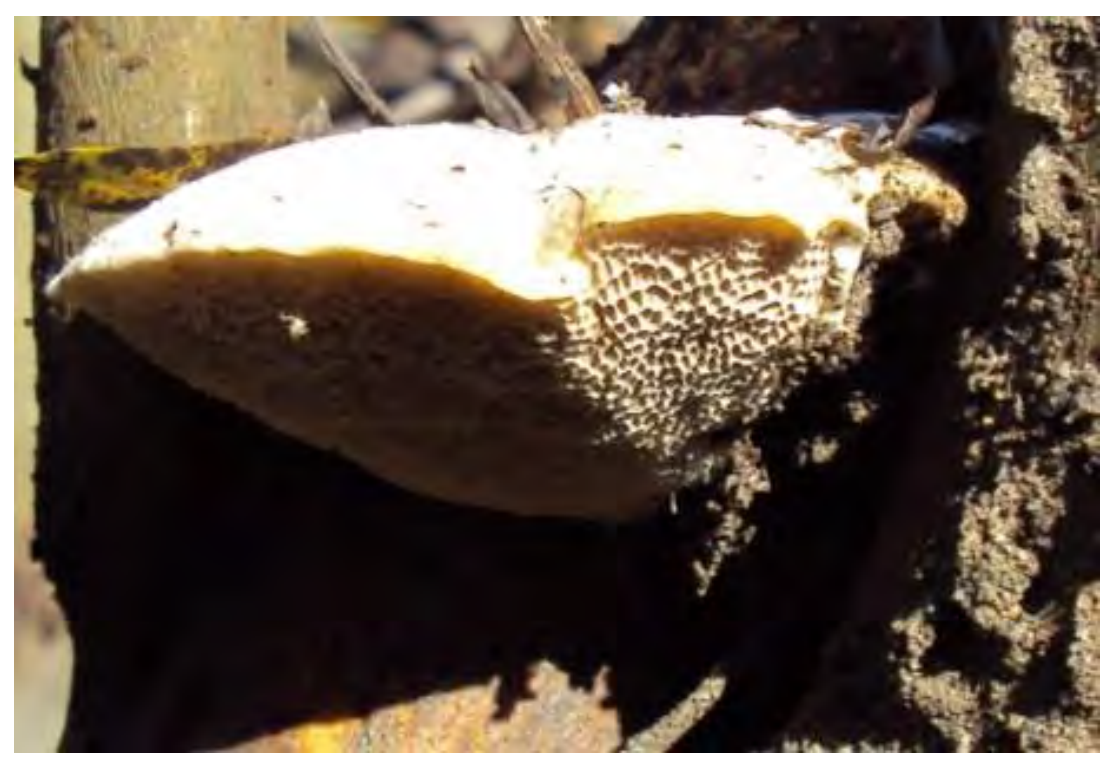

46. ábra: $S$. caprea CA1 négyéves tövén fejlődött taplógomba (fotó: Treerné, 2010) rosmarinifolia esetében elsösorban a levéllemezen megjelenő foltokra korlátozódtak, hajtáselhalást csak a $S$. purpurea töveken tapasztaltam.

A törzs- és tőkorhasztó gombák közül egy példány megtelepedett soroksári ültetvényemben $S$. caprea CA1 klón négyéves tövén (46. ábra), de ez rövid távon nem volt negatív hatással a vesszőhozamra. A Dunakeszi láp bejárása közben megfigyeltem egy méretes parázstaplót (Phellinus igniarius) törékeny füz (S. fragilis) törzsén.
\end{abstract}

\title{
4.3.2 Kártevők
}

A cinegefüzt alkalmanként nagy mennyiségben szállják meg levéltetvek. A gyüjtők beszámoltak róla, hogy egyes tövekről nem tudnak vesszőt szedni, annyira „hangyás”. A hangyák a levéltetvek által kiválasztott mézharmat miatt lepik el a növényeket. A többi füz fajt is gyakran károsítják levéltetvek a vegetációs időben, különösen intenzív körülmények között, anyatelepeken, ültetvényekben, ezek ellen azonban könnyen és hatásosan lehet védekezni. A 2003 tavaszán szaporított füzeket konténerben, egy budapesti kertben, a Budai-hegyek közelében tartottam. Nyáron nagy mennyiségü levéltetủ lepte el a leveleket és hajtásokat, de már egy kezelés (Bi 58 permetezés) hatásosnak bizonyult ellenük. Ugyanezeken, valamint az egy évvel később szaporított példányokon 2004 nyarán budaörsi kertemben nem jelentek meg levéltetvek, annak ellenére, hogy állítólag abban az évben jelentősek voltak a levéltetủ károsítások (HALTRICH, 2004, szóbeli közlés). A gyüjtők fekete levéltetveket emlegettek, melyek nagy számban ellepték a növényeket. Károsításuk nyomán a hajtáscsúcs elhal vagy elágazódik. Ha ez utóbbi a vegetációs időszakban később következik be, az elágazások vége nem érik be, és a tél folyamán károsodhat. Soroksáron 2008 júniusában Chaitophorus salijaponicus szárnyatlan alakjait figyeltem meg S. purpurea tö- 


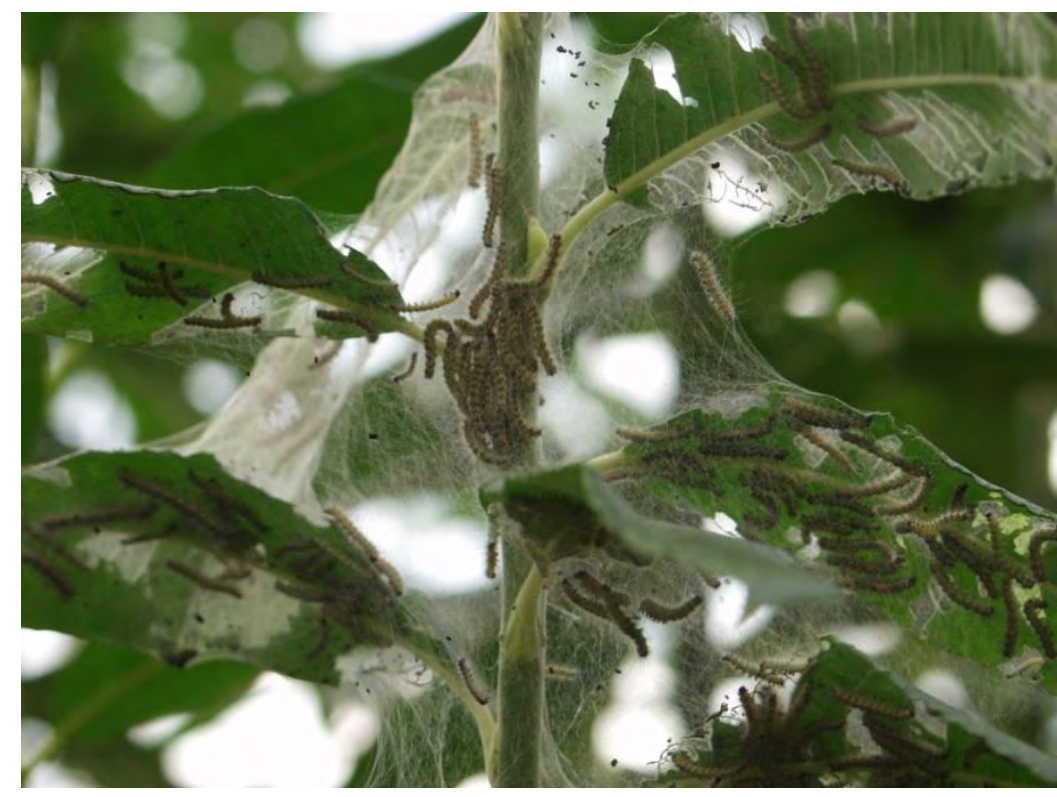

47. ábra: Szövőlepke hernyók $S$. x smithiana hajtásán egy dabasi termesztőnél (fotó: Dobos) veken, és $C$. salicti szárnyatlan alakját $S$. caprea levelein. Ez utóbbi fajon Pterocomma salicis is szívogatott.

Egy dabasi kertben, barkás vessző termesztés céljából ültetett szépbarkájú füz $(S . \quad \mathrm{x}$ smithiana) tövein szövőlepke hernyókat figyeltem meg szeptember elején, melyek foltokban tarrágást okoztak (47. ábra). Ez jelentős kártevője lehet a barkás füzeknek, mert nagyobb mértékü

károsítás esetén lomb hiányában leállhat a hajtásfejlődés, és a vesszők nem érnek be kellőképpen. A hernyókat meghatározva ez a kártevő az Arctornis l-nigrum faj volt.

A soroksári ültetvényben $S$. purpurea tövein több levélen megfigyeltem a Pontania vesicator levéldarázs pirosas-lilás gubacsait. A gubacsokat a Dísznövénytermesztési és Dendrológiai Tanszék laboratóriumában petricsészében tartva sikerült megfigyelnem a gubacsból kikelő lárvák bebábozódását, mely a természetben a talajban történik [VÉTEK 2010, szóbeli közlés]. Ennek hiányában az álhernyók a petricsésze alján elhelyezett, enyhén megnedvesített papírtörlő alá másztak be bábozódás végett. A darázs kártétele tapasztalataim szerint nem veszélyezteti a barkás vesszők minőségét vagy hozamát.

A Flora Hungaria nagybani virágpiacon 2010-ben és az azt követő években mind több termesztő panaszkodott arról, hogy egy kártevő pusztítja a növényeiket, melynek hernyója a törzsben rág. S. caprea Hollandiából származó, kifejezetten barkás vessző termesztés céljára nemesített 'Silberglanz' fajta ültetvényeiben jelent meg, és súlyos kártételének nyomán több növény teljesen

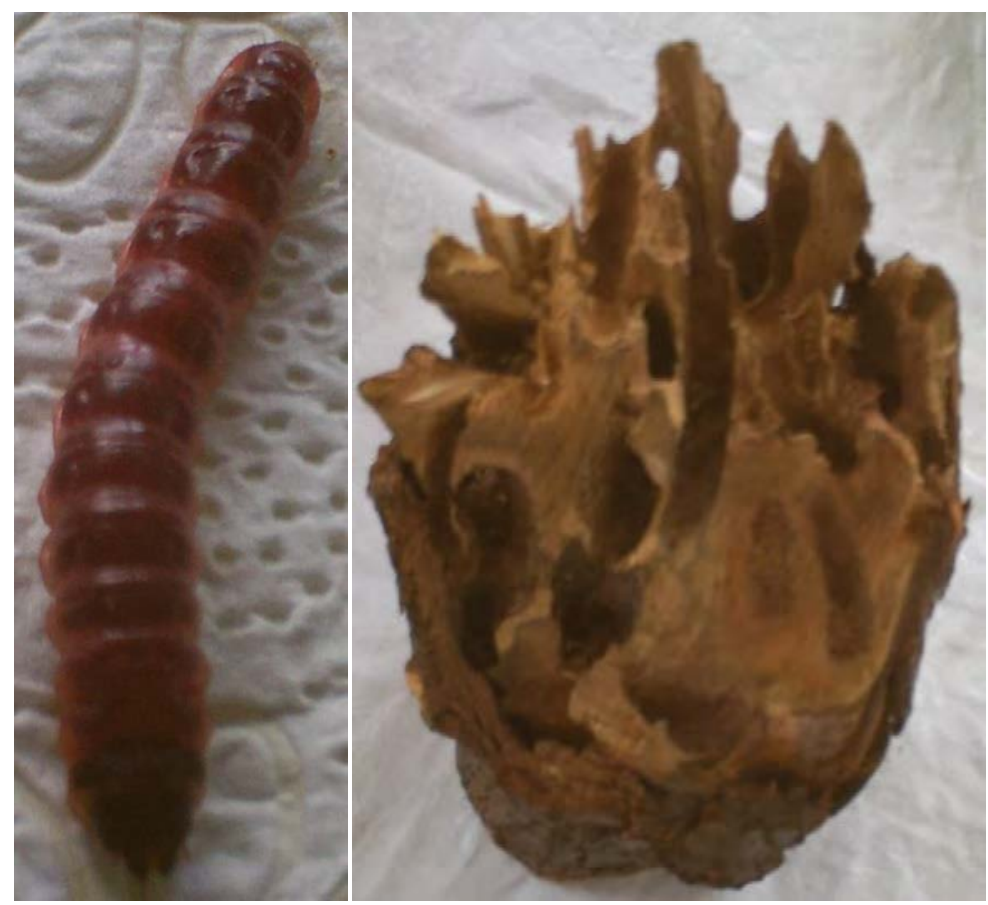

48. ábra: Cossus cossus fiatal lárvája és kártétele füzfában (fotó: Treerné, 2013) 
kipusztult. 2013 tavaszán egy termesztőtől kaptam egy károsított, szivacsszerüen lyukacsos füzfatönköt, valamint hat élő lárvát. A 6-8 cm hosszú, húsvörös színü fiatal valódi hernyók, továbbá a fatestben az elliptikus keresztmetszetü járatok alapján meghatároztam a nagy farontólepkét (Cossus cossus) (48. ábra - elöző oldal alja).

A kártevők közé sorolhatók - KISS FERENC erdész megjegyzését megerősítve - a gyüjtők is. Bár a vesszők levágása nem árt a töveknek, a gyüjtés sokszor védett területen történik, ez az illegális tevékenység az adott területen okoz kárt. A cinegefüz vesszőit decemberben virgácsnak is gyüjtik, és aranyfestékkel lefújva értékesítik. Lajosmizse közelében jártam olyan területen, ahol a $S$. rosmarinifolia több négyzetméteres sarjtelepeit ilyen célból tél elején tövig levágták. A nehezebben elérhető vesszők megszerzése miatt tőből kivágott nagyobb termetü Salix egyedek szintén a Homo sapiens L. kárképei.

\subsubsection{Egyéb minőségrontó tényezők}

A hajtásfejlődés közben bekövetkező jégverés komoly kárt okozhat a barkás vesszőkön. A sérülések következtében parásodott foltok keletkeznek, melyek a színes vesszők díszítőértékét rontják. S. purpurea színes vesszőin 2007 tavaszán figyeltem meg jégverés által okozott parásodott foltokat, melyek a fényes bordó vesszőkön valóban nem bizonyultak dekoratívnak.

A gyüjtők panaszai alapján az egyszerü körülmények között tároláskor egér és meztelencsigák okoznak károkat - a barkák megrágásával az árut akár teljesen tönkretehetik. Szintén minőségi kárként jelenik meg a csiga nyálkája, valamint az egér ürüléke a kötegben. Nem károsítótól származik, de tárolási probléma, ezért itt említem, hogy esetenként a nagy mennyiségben együtt tárolt vessző-köteg „,begyullad”, és a barkák leesnek. Ennek különösen a magas páratartalom és -hőmérséklet kedvez, ezért ilyen körülmények között kerülendő a tárolás.

Egy dabasi termesztő 2004 tavaszán hívta fel rá a figyelmemet, hogy a begyüjtött barkás vesszöket károsítja valami. Hamarosan alkalmam nyílt a kártétel megfigyelésére: néhány köteg barkás vessző, melyet a nagybani virágpiacon vettem, a beszerzést követő pár napon belül darabjaira hullott, mintha a barkákat egyenként szétmorzsolták volna. Különböző méretű hernyók rágták a barkákat. A lárva alapján próbáltam meghatározni a fajt, de mivel ez a módszer köztudottan nem egyértelmü, kineveltem az imágót. Egy befőttesüveg aljára ujjnyi tőzeget töltöttem, betettem néhány füz levelet, végül a hernyókat. A nagyobbak hamarosan bebábozódtak, végül július 27-én kikelt egy bagolylepke. Az imágót Dr. MÉSZÁROS ZOLTÁN segítségével határoztam meg. Xanthia togata bagolylepke lárvája károsította a vesszőket. Ez a faj egynemzedékes, a pete telel át. Valószínüleg a tél végén behozott vesszőkön a szokásosnál korábban kikeltek a kis lárvák, és azok kezdték a barkát rágni. A raktár vagy egyéb tároló pedig olyan hely, ahol a természetes 
ellenségek, például madarak nincsenek jelen, ezért a hernyók táplálkozásának és növekedésének nem volt semmilyen akadálya.

\subsection{Salix rosmarinifolia vesszők nyílasztása}

A gyöngybarka vesszők kezelésének módja a 2.4 fejezetben ismertetett terminológiák közül a nyílasztás és a hajtatás fogalmához áll közel. Azért nem nevezhető nyílasztásnak, mert az eljárás célja csak a generatív rügyek fejlődésének megindítása. Eredményes a kezelés, ha a rügyek megpattannak, és a virágzati tengely megnyúlásából adódóan a fejlődő barkák előtünnek a rügypikkelyek takarásából. Ha valóban „kinyílna” a virágzat, az már nem eredményezne piacképes árut. A kertészeti szakirodalom szerint ez valódi hajtatás. Mivel a differenciálódott virágzati rügyekről a rügypikkely legalább részbeni leválása a cél, tehát annak a stádiumnak az elérése, mikor a barkák legalább harmadrészben kilátszanak már a rügypikkely takarása alól, mégis nyílasztásnak nevezem ezt az eljárást, mert közelebb áll ahhoz, ahogy egy zárt bimbót kinyílásra késztetünk. Mindkét esetben a virágfejlődést gyorsítjuk, csak a gyöngybarka vesszőknél korábbi stádiumban lezárul a folyamat.

A vesszőkön azok szedésekor az apró rügyek mindegyike zárt, rügypikkellyel szorosan fedett volt. A kísérlet beállítását követő ötödik napra a gibberellines oldatokban lévők elkezdtek megpattanni. A vízben lévő vesszők rügyei teljesen zártak maradtak (49. ábra). A kontroll esetében a vékony, egyszálas veszőkön semmi változást nem tapasztaltam, a többéves résszel szedett és vízbe állított ágak vesszőin két-három virágzati rügy megduzzadt.

Az 1,5\% $\mathrm{GA}_{3}$ hormonkoncentrációjú oldatba állított vesszők közül elsősorban azok kezdtek intenzíven nyílni, melyek többéves ágrésszel kerültek az oldatba. Az idősebb ágakból elágazó vesszők csúcsi részén kezdődött a nyílás. A kezdetben rügypikkellyel fedett, átlagosan 3-4 mm hosszú és 1,5 (-2) mm széles virágzati rügyekböl viszonylag nagy barkák fejlődtek, melyek hossza 4-6 mm, szélessége 4(-5) mm volt. Jellemzően a vesszők csúcs felé eső $5 \mathrm{~cm}$-es részén kezdtek nyílni a kísérlet első hetében (50. ábra). A második héten a felső $15 \mathrm{~cm}$-es vesszőrészen található rügyek 90\%-a megpattant.

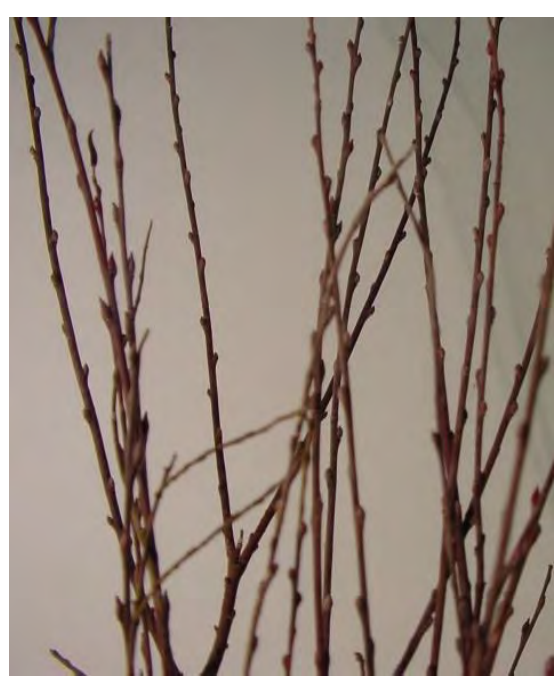

49. ábra: Zárt rügyek a vízben lévő $S$. rosmarinifolia vesszőkön (fotó: Treerné, 2006). 


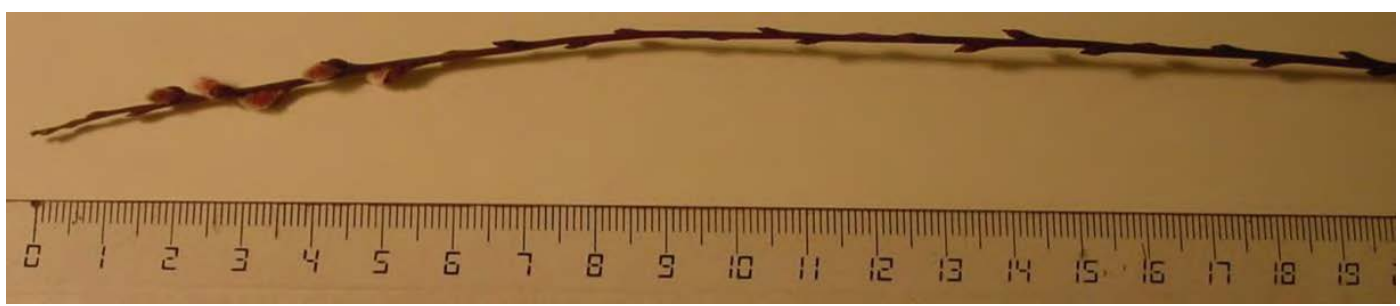

50. ábra: Megpattanó virágzati rügyek a vessző felső 5 cm-én (fotó: Treerné, 2006).

Ugyanebben az oldatban az első héten a vékonyabb, egyszálas vesszőkön csak egy-két barka indult fejlődésnek és bújt részben elö a megpattant rügypikkely alól (51. ábra).

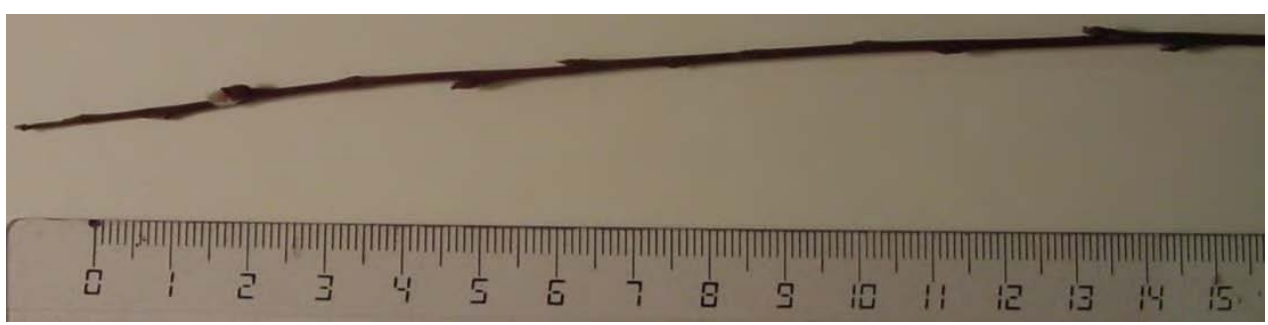

51. ábra: Egy-egy megpattanó virágzati rügy vékony gyöngybarka vesszőn (fotó: Treerné, 2006)

A második héten is folytatódott ez a tendencia, vagyis a vékony, egyszálas vesszőkön - a bokros, elágazódó, idősebb szárrészt tartalmazókkal szemben - elszórtabban lehetett kinyílt barkákat találni, a csúcshoz közelebb esők nyílása nem volt egységes. A fejlődő barkák a második hétre jobban, 6-7 mm hosszúra megnyúltak, mint a 6\%-es oldatban lévők. A 1,5\%-es nyílasztó oldatba állított vesszökön a megpattanó virágzati rügyek aránya a zárt rügyekhez képest a kísérlet beállítását követő negyedik napon 20\%, egy hét elteltével 30\%, két hetesen közel $44 \%$ volt, és ez az arány egy héttel később is maradt, a rügyek nem nyíltak tovább.

A 6\% $\mathrm{GA}_{3}$ hormonkoncentrációjú nyílasztó oldatba állított vesszők intenzívebben nyílásnak indultak, mint a másfél ezrelékesben. Ebben az oldatban is a vesszők csúcs felöli végén fakadtak egységesebben a rügyek, kivéve a vesszők csúcsát. A csúcsi részen ugyanis általában 2-3 db, nagyon apró hajtásrügy található, melyek ilyenkor még teljesen zártak maradnak (52. ábra következő oldal teteje). 


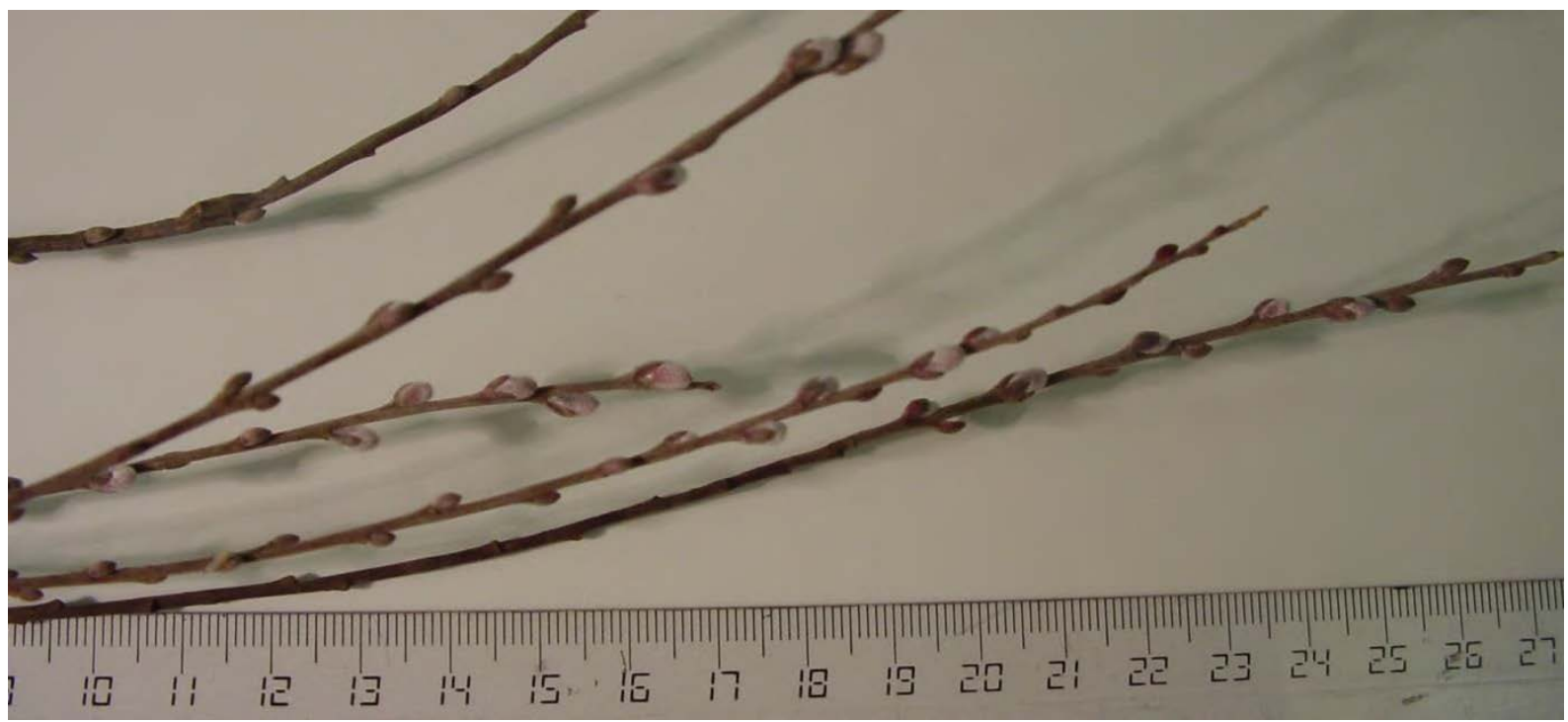

52. ábra: $\mathrm{GA}_{3}$ hatására megpattanó virágzati rügyek $S$. rosmarinifolia vesszőkön (fotó: Treerné, 2006)

Szintén jelentős volt a különbség a többéves résszel leszedett, és a vékony, egyéves, egyszálas vesszők között (53. ábra). Az idősebb szárrésszel levágott, és így a nyílasztó oldatba állított veszszők egységesebben nyíltak, és már az ötödik napon piacképessé váltak. A vékony, egyszálas vesszők csúcsi részén a kezelés kezdete után öt nappal 4-6, esetenként 8 rügy megpattant.

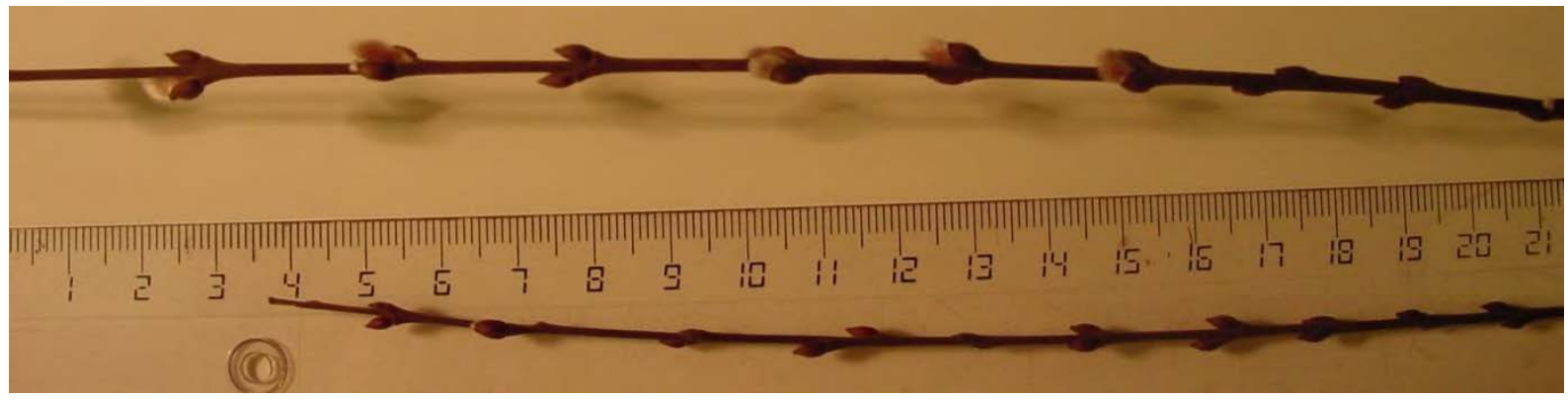

53. ábra: Vastagabb és vékonyabb gyöngybarka vessző fakadó és zárt virágzati rügyekkel (fotó: Treerné, 2006)

A 6\%o-es oldatban végül a következőképpen alakult a barkák nyílása. Az átlagosan 45-50 cm hosszú, vékony, egyszálas vesszőkön főleg a vessző felső 10-14 cm-es szakaszán pattantak meg a rügyek. A barkák csak félig duzzadtak meg, kétharmad részük látszott ki a fennmaradó rügypikkely alól. Így az $5 \mathrm{~mm}$ hosszú, 2-3 mm széles zárt rügyekböl $5 \mathrm{~mm}$ hosszú és 2-3 mm széles barkák fejlődtek. Ugyanakkor akadt olyan vékony, egyszálas vessző, melyen egyetlen rügy sem pattant meg, bár megduzzadtak, a fejlődés megindult bennük. A vastag, idősebb szárrészt tartalmazó, elágazó vesszőkön szintén a feljebb elhelyezkedő rügyek pattantak meg. Ezek a barkák sem nyúltak meg, inkább megduzzadtak (gömbölyübbé váltak), és a murvapikkelyeken lévő ezüstös szőrök alatt rózsaszínűvé színeződtek. A 6\%o-es oldatba állított vesszők közül a vastagabb aljú, idősebb részt tartalmazó ágak vékony vesszői jobban kinyíltak, az egyszálasak kevésbé. A nagyon vékony (1,5 mm átmérőjü) vesszők, vagy a nagyon kisméretü rügyek egyáltalán nem nyíltak ki. A töményebb $\mathrm{GA}_{3}$ tartalmú nyílasztó oldatba állított vesszőkön kezdetektől 
nagyobb arányban nyíltak meg a barkák; négy nap elteltével már a rügyek átlagosan 30\%-a megpattant, egy hét elteltével ez az arány 45\% volt, ami alapján az árut piacképesnek lehetett nyilvánítani.

A kontrollként vízbe helyezett vesszők barkái csak a kísérlet beállítását követő hét nap múlva kezdtek megpattanni, és tíz nap múlva bújtak elő a rügypikkely takarásából. A vízben is az idősebb szárrészt tartalmazó ágak vesszőin fejlődtek intenzívebben és egységesebben a barkák a vékonyabb egyszálas vesszőkön lévőkhöz képest. A nagyon kisméretű (2 mm hosszú, 0,5-1 mm széles) rügyek zártak maradtak. A vízben a vesszők csúcsi része felé a rügyek harmada, közel fele megpattant, de a duzzadás mértéke a 3-4 mm x $2 \mathrm{~mm}$-t nem haladta meg. A rügyek mögött többnyire fennmaradt a rügypikkely. A kontroll számszerü eredményei a következőkben összegezhetők: a vesszők négy nap elteltével még nem mutattak változást, hét nap múlva azonban már a virágzati rügyek 15\%-a megpattant, 14 nap múlva a nyílás aránya $25 \%$ fölé emelkedett, majd stagnált a kísérlet végéig.

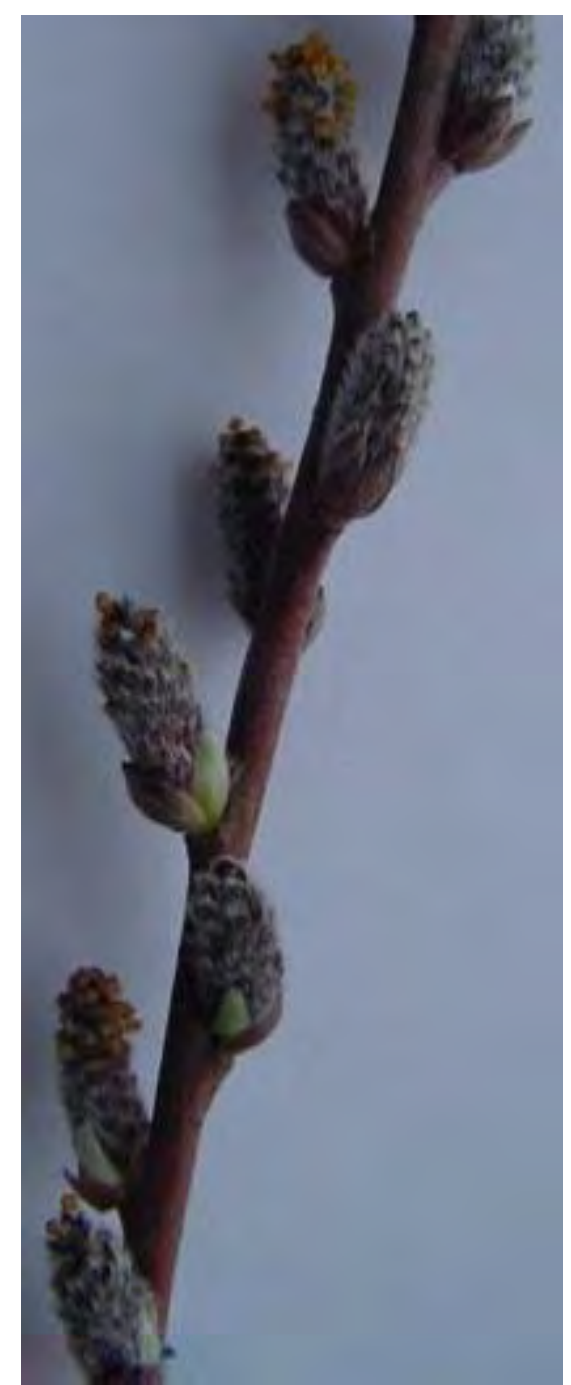

Egyedül vízben tapasztaltam azt, hogy az egyik idősebb szárrészt tartalmazó, valamint egy vékony egyszálas vessző alján vékony gyökér fejlődött. Az egész kísérletben összesen 5-6 db barka kezdett botanikai értelemben virágozni, ezt is csak a vízben produkálták a vesszők (54. ábra).

A különböző nyílasztó oldatokban megpattanó virágzati rügyek arányait összegzi a 10. táblázat.

54. ábra: Vízben tartva kivirágzó gyöngybarka vessző (fotó: Treerné, 2006) 
10. táblázat: Megpattanó virágzati rügyek százalékos aránya a zárt rügyekhez képest $S$. rosmarinifolia veszszőkön

\begin{tabular}{|l|l|l|l|l|}
\hline \multirow{2}{*}{ Kezelések (nyílasztó oldatok) } & \multicolumn{4}{|c|}{ A kísérlet beállításától eltelt idő: } \\
\cline { 2 - 6 } & 4 nap & 7 nap & 14 nap & 21 nap \\
\hline kontroll & $0 \%$ & $14,986 \%$ & $25,16 \%$ & $25,167 \%$ \\
\hline 1,5 ppm $\mathrm{GA}_{3}$ & $19,69 \%$ & $29,72 \%$ & $43,708 \%$ & $43,708 \%$ \\
\hline 6 ppm $\mathrm{GA}_{3}$ & $29,64 \%$ & $44,842 \%$ & $44,842 \%$ & $44,842 \%$ \\
\hline
\end{tabular}

\subsection{A tartósító kezelések hatása Salix vesszők rugalmasságára és morfológiai paramétereire}

\subsubsection{Salix caprea vesszők tartósításának eredményei}

\section{A rugalmassági modulus alakulása}

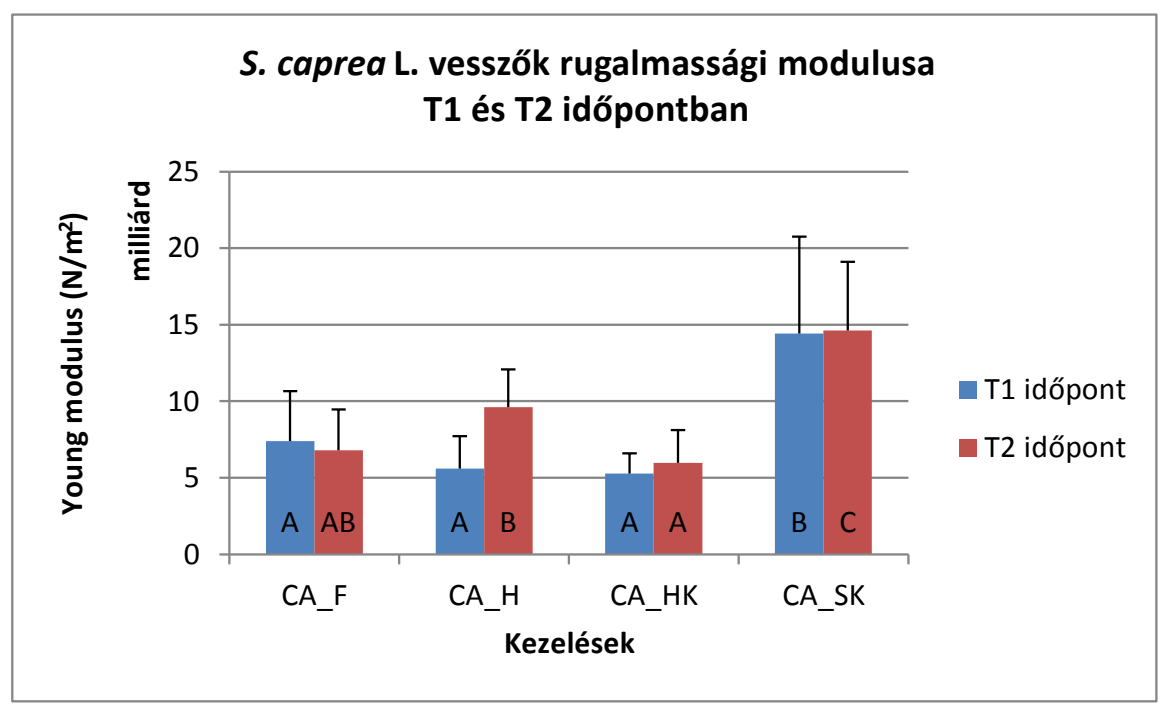

55. ábra: $S$. caprea vesszők rugalmassági modulusa (Young-modulus) az 1. és 2. mérési időpontban

Az első mérési időpontban a háromféle kezelés eredménye még szignifikánsan nem különbözött egymástól. A száraz kontroll vesszők rugalmassági modulusa már ebben az időpontban szignifikánsan eltért, lényegesen magasabb volt a kezelt vesszők értékeihez képest. A háromféle kezeléssel enyhén eltérő eredményeket értem el (55. ábra): a vizsgálat elején (T1) legalacsonyabb Young-modulus értékeket a folyamatosan hütőben tartott vesszők esetében (HK kezeléssel) kaptam, majd a kezdetben hütőben, később szobahőmérsékleten tartott vesszők $(\mathrm{H})$ értékei következtek, és némileg magasabb értékeket értem el a glicerines felszívatással (F kezeléssel).

A második mérési időpontban már szignifikánsan különbözött a csak kezdetben $(H)$, illetve a folyamatosan hütőben tartott (HK) vesszők rugalmassági modulusa. Legmagasabb Youngmodulus értékeket továbbra is a száraz kontroll (SK) vesszők eredményeztek, ebben az időpontban még szignifikánsan különböztek az összes többi kezeléstől (55. ábra). A felszívatott vesszők (F) rugalmassági értékei az egymástól szignifikánsan különböző, kezdetben hütött $(\mathrm{H})$ és folya- 
matosan hütőben tartott $(\mathrm{HK})$ kezelések értékei között helyezkedtek el, egyik értéktől sem tértek el szignifikánsan.

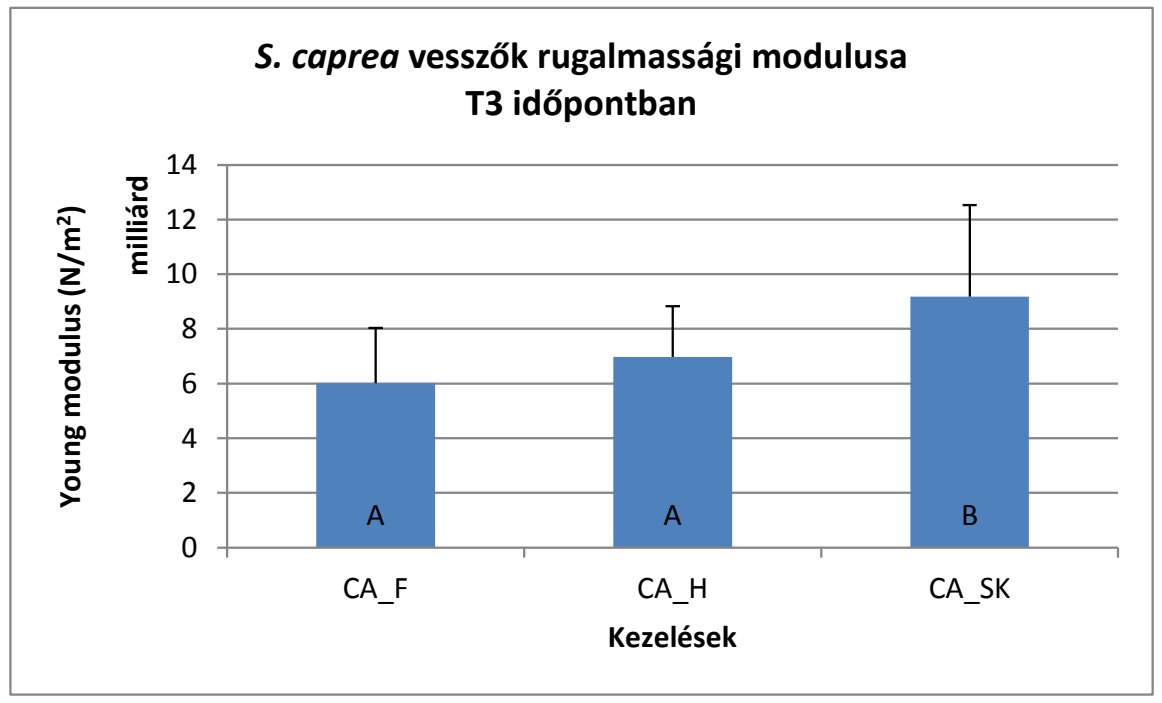

56. ábra: $S$. caprea vesszők rugalmassági modulusa a 3. mérési időpontban

A harmadik mérési időpontban az eredmények, illetve azok különbségei megegyeztek az előző időpontban mértekkel. A felszívatott, és a kezdetben hűtőben tartott vesszők (F és H kezelések) eredményei még szignifikánsan nem különböztek, bár a glicerines (F) kezelés alacsonyabb Young-modulus értékeket eredményezett (56. ábra), és mindkettőhöz képest szignifikánsan eltérő, magasabb értékeket kaptam a száraz kontroll (SK kezelés) esetén.

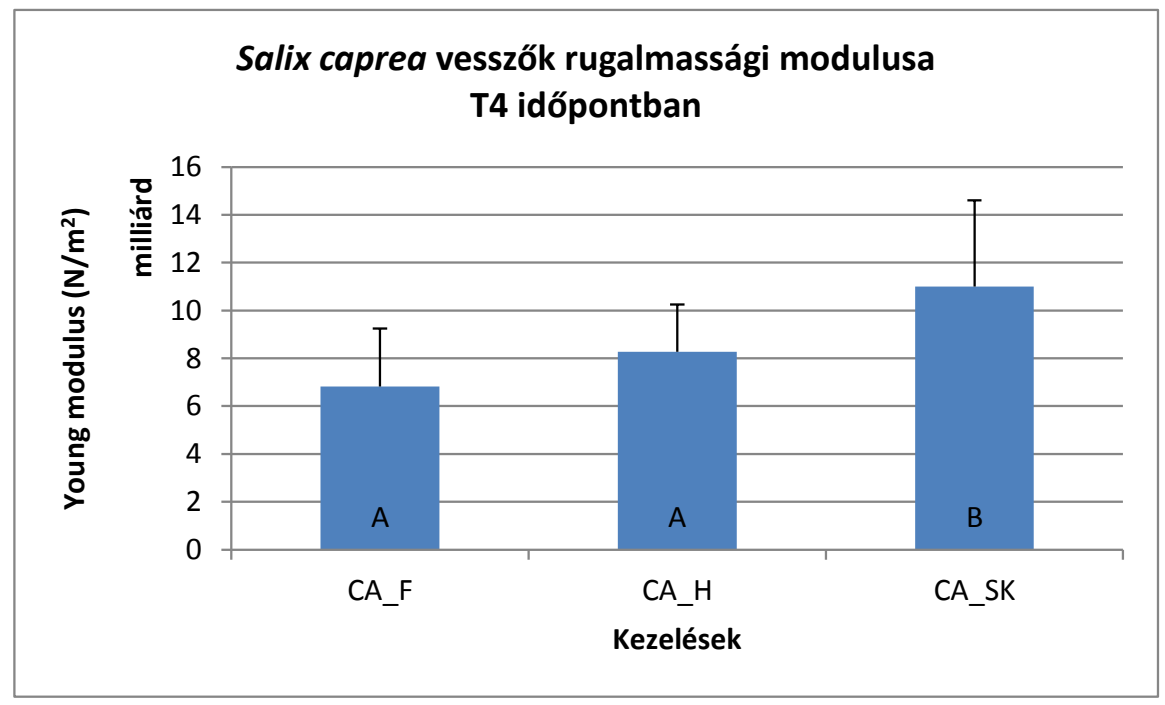

57. ábra: $S$. caprea vesszők rugalmassági modulusa a 4. mérési időpontban

A negyedik mérési időpontban még mindig hasonló különbségeket tapasztaltam, mint az előző két időpontban. Legalacsonyabb Young-modulus értékek a glicerines (F) kezelés eredményeképpen adódtak, majd a kezdetben hütve, később szobahőmérsékleten való tárolás ( $\mathrm{H}$ kezelés) értékei következtek. Ezektől szignifikánsan különböző, magas értékeket kaptam a szárazon, szobahőmérsékleten tartott kontroll vesszők (SK) esetében. Az előző mérési időpontban kapott 
eredményekhez képest viszont nőtt a glicerines (F) és a kezdetben hütve, később szobahőmérsékleten való tárolás (H kezelés) eredményei közötti különbség (57. ábra - előző oldal alja).

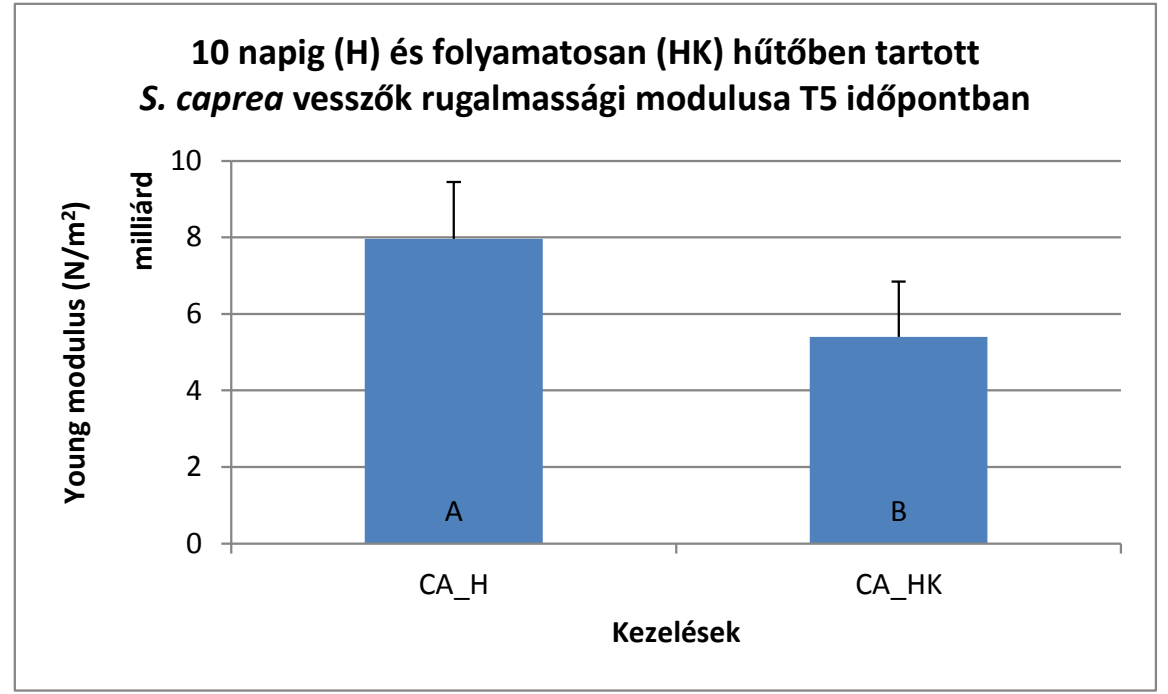

58. ábra: Kétféle hütéses kezelés eredményei $S$. caprea vesszőknél az 5. mérési időpontban

Az ötödik mérési időpontban szignifikáns különbség volt kimutatható a csak kezdetben, és a mindvégig hütőben tárolt vesszők ( $\mathrm{H}$ és HK kezelések) eredményei között, a folyamatosan hütőben tartott vesszők (HK kezelés) esetén alacsonyabb Young-modulusokkal (58. ábra). Ekkor már egyértelmüen megmutatkozott, hogy a folyamatosan hütőben tartott vesszők (HK kezelés) rugalmassági értékei szignifikánsan alacsonyabbak voltak, mint a hütőből kivett csoporté, ezt a kétmintás T-teszttel is alátámasztottam.

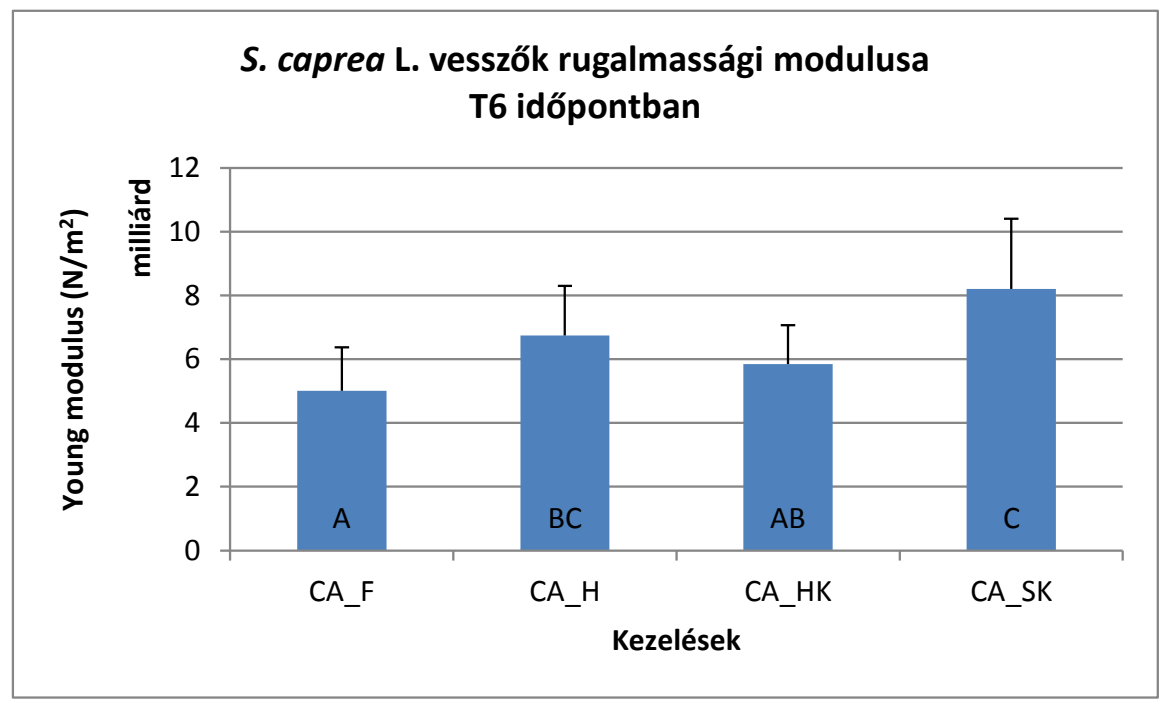

59. ábra: $S$. caprea vesszők rugalmassági modulusa a 6. mérési időpontban

A hatodik mérési időpontban, 16 héttel a kísérlet beállítását követően a glicerinnel felszívatott (F kezelés) vesszők Young-modulusa maradt a legalacsonyabb, és szignifikánsan különbözött a kezdetben hütőben (H kezelés), és a szobahőmérsékleten, szárazon tartott vesszők (SK kezelések) eredményeitől. Legmagasabb Young-modulus értékeket a szárazon tartott kontroll vesszők (SK) mérésekor kaptam, melyek szignifikánsan különböztek a glicerines és a folyamatos 
hütő-tárolásos (F és HK) kezelések esetében kapott értékektől. A kezdetben hütőben, majd szobahőmérsékleten tárolás (H kezelés) értékei a folyamatosan hütőben tartott (HK) és a szárazon, szobahőmérsékleten tartott kontroll vesszők (SK) értékei között helyezkedtek el, és mindkettővel mutattak azonosságot. A diagramon (59. ábra - előző oldal alja) azonban jól látszik, hogy a kezdetben hütőben, majd szobahőmérsékleten való tartás (H kezelés) értékei a folyamatosan hütőben lévő kontrollnál (HK kezelés) magasabb, a száraz kontroll (SK kezelés) értékeinél alacsonyabb értékeket adtak. A folyamatosan hütőben tartott vesszők (HK kezelés) alacsonyabb értékei a felszívatott vesszők (F kezelés) és a kezdetben hütőben, majd szobahőmérsékleten tartott (H kezelés) értékei között helyezkedtek el, és mindkettővel mutattak azonosságot. Ugyanakkor itt is (HK kezelés) egyértelmü volt, hogy a glicerinnel felszívatott vesszők (F kezelés) értékeinél magasabb, a kezdetben hütőben, majd szobahőmérsékleten tartott vesszők (H kezelés) értékeinél viszont alacsonyabb értékei voltak a rugalmasságnak.

\section{A kezelések hatásának alakulása az idő folyamán és az eredmények kvantitatív érté- kelése $S$. caprea vesszők esetén}

A glicerinnel felszívatott vesszők (F kezelés) eredményeit a különböző mérési időpontokban ábrázoló 60. ábra azt mutatja, hogy a rugalmassági modulus az idő során gyakorlatilag állandó volt, csak az első és az utolsó mérési időpont között volt szignifikáns különbség.

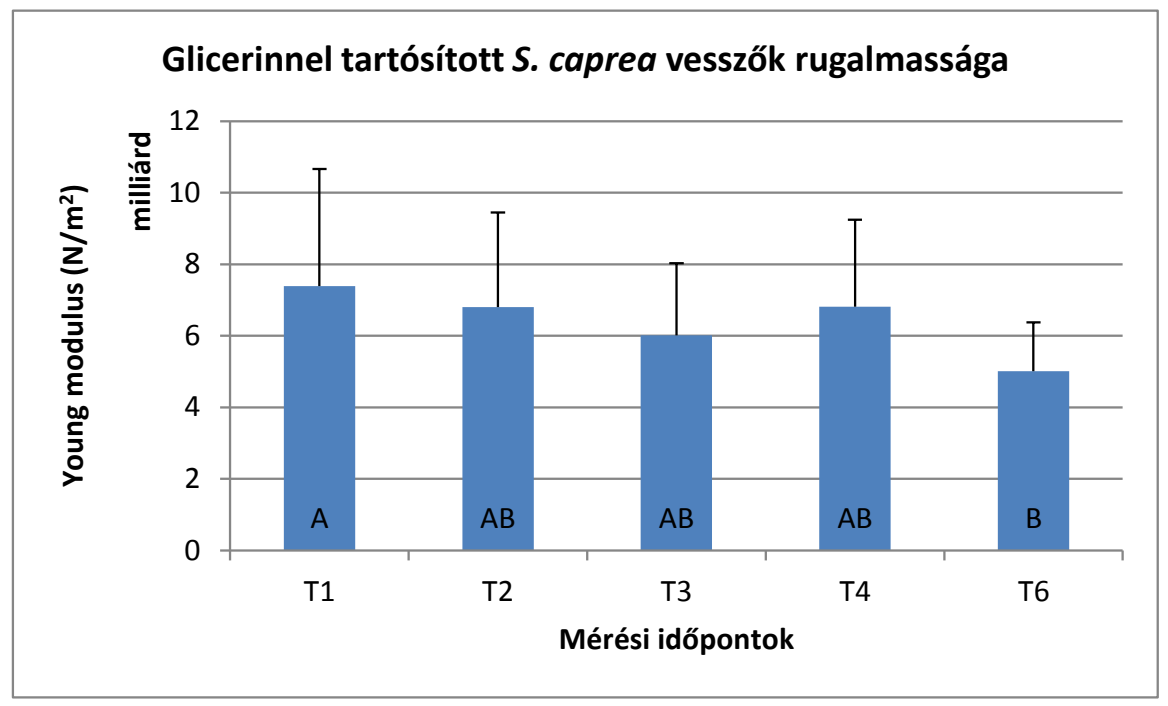

60. ábra: Glicerinnel felszívatott $S$. caprea vesszők rugalmassága a különböző mérési időpontokban

A kezdetben hűtőben, majd szobahőmérsékleten, szárazon tartott vesszők (H kezelés) értékei a negyedik mérési időpontban különböztek szignifikánsan az első időpontban mért értékektől. Az idő változásával nem volt kimutatható szignifikáns különbség a folyamatosan hütőben tartott vesszők (HK kezelés) eredményei között. 


\section{Kezelések hatása $S$. caprea vesszők morfológiai paramétereire}

A szedést követő hatodik napon a szárazon, szobahőmérsékleten tartott kontroll vesszőkről átlagosan 1,5 db barka/szál hullott le, valamint a száraz rügypikkelyek. A barka méretek csökkentek, a barkák összeszáradtak. A barkák vesszővel bezárt szöge is nőtt, megközelítette a $90^{\circ}$ ot, a barkák jobban elálltak a vesszőtől, mint frissen. A barkák szemmel is látható összeszáradásán túl ez a jelenség a vesszőkön tapintással is érzékelhető volt. A háncs alatti hosszanti bordák (kéreg alatti lécek) kidudorodtak, a vesszők lekopaszodtak, míg a glicerines felszívató oldatban molyhosak maradtak. Az összeszáradt barkák érintésre, rázkódásra könnyen letörtek. A barkák átlagos mérete (hosszúság x szélesség): 12,94 mm x 8,35 mm volt. A szobahőmérsékleten, szárazon tartott kontroll vesszők folyamatos kiszáradását a mind jobban kidudorodó kéreg alatti lécek, és a folyamatosan hulló barkák is jelezték.

A barkák a glicerines felszívató oldatban nem fejlődtek (nem nyúltak, és nem is nyíltak) tovább, de nem is száradtak össze, mint a száraz kontroll vesszőkön. A vesszők felülete ép, nem ráncos, nem száradt össze, és molyhos maradt. A felszívató oldatban álló vesszőkről egyetlen barka sem hullott le. Ugyanakkor a barkák tövében még fennmaradt egy-két rügypikkely teljesen kiszáradt, és a vesszők érintésekor könnyen leesett. Az eleinte áttetsző felszívató oldat enyhén színeződött el, halvány barnás színüvé változott. Az oldatba érő szárrészek világosabb zöld színüek maradtak, a vesszők többi része barnászöld lett. A felszívató oldatban lévő vesszők tapintásra is lágyabbak, rugalmasabbak maradtak, mint a száraz kontroll vesszők. A barkák átlagos mérete (hosszúság x szélesség): 18,48 mm x 9,11 mm volt. Az első mérési időpontban a hütött kezelésekben részesített vesszők tíz napja voltak hütőben, így az első időkben hütött $(\mathrm{H})$, valamint a folyamatosan hütött (HK) vesszők mérési eredményei között még nem lehetett különbséget mérni. Erős rázás és ütögetés hatására mindössze átlagosan $0,42 \mathrm{db}$ barka/vessző hullott le. A vesszők színe halványzöld, felületük tapintásra sima, enyhén molyhos maradt.

A hűtőben tartott vesszőkön a barkák még az utolsó mérési időpontban is dekoratívak, a kifakult száraz vesszők barkáihoz képest feltűnően feketék maradtak. Tapintásra puhák maradtak, de a vesszőket nem lehetett olyan könnyedén hajlítani, mint a glicerinnel felszívatott kezelési csoportokat. A barkák alig váltak le, a szobahőmérsékleten, szárazon tartott kontroll vesszők sokkal hiányosabbak voltak. A mindvégig hütőben tartott vesszők színe hamvas barna lett, a hosszanti lécek enyhén kidudorodtak, de korántsem száradtak össze annyira, mint a szárazon, szobahőmérsékleten tartott kontroll. 


\subsubsection{Salix purpurea vesszők tartósításának eredményei}

\section{A rugalmassági modulus alakulása}

Már az első mérési időpontban szignifikáns különbség mutatkozott a folyamatosan hütőben tartott (HK), a glicerinnel felszívatott (F), és a szárazon, szobahőmérsékleten tartott, kontroll vesszők (SK) eredményei között (61. ábra). Legalacsonyabb rugalmassági modulusa a folyamatosan hütöben tartott (HK-kezelt) vesszöknek volt, ezeket követték a glicerinnel felszívatott vesszők értékei, és az összes többi kezeléstől szignifikánsan különböztek a szárazon, szobahőmérsékleten tartott vesszők, legmagasabb Young-modulus értékekkel. A kezdetben hütőben tartott, majd onnan kivett vesszők értékei a glicerinnel felszívatott, és a folyamatosan hütöben tartott vesszők eredményei között helyezkedtek el, de szignifikánsan egyiktől sem különböztek.

A második mérési időpontban a glicerinnel felszívatott vesszők (F kezelés), és a kezdetben hütőben, majd szobahőmérsékleten, szárazon tartott vesszők (H kezelés) eredményei még mindig nem különültek el szignifikánsan, ugyanakkor a kétféle hütőben végzett történő kezelés (H és HK kezelés) között már szignifikáns különbség volt. A második mérési időpontban még mindig a hütött kontroll, azaz a folyamatosan hütőben tartott vesszők (HK kezelés) eredményei adták a legalacsonyabb Young-modulus értékeket.

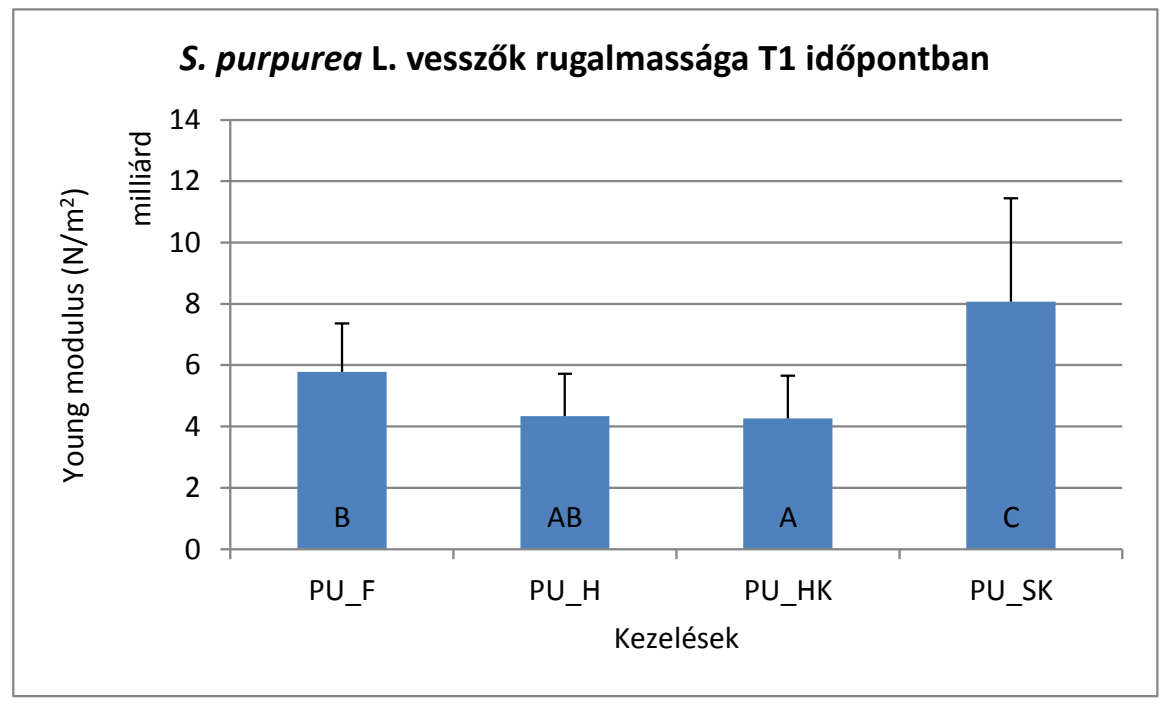

61. ábra: $S$. purpurea vesszők rugalmassága az 1. mérési időpontban

A harmadik mérési időpontban látszott először egyértelműen, hogy a glicerinnel felszívatott vesszők Young-modulus értékei alacsonyabbak lettek, mint a kezdetben hütőben, majd szobahőmérsékleten, szárazon tartott vesszők rugalmassági modulusa, de ez a különbség még nem volt szignifikáns. A negyedik mérési időpontban tovább nőtt a különbség az alacsonyabb Youngmodulus értékeket eredményező glicerinnel kezelt vesszők, és a kezdetben hütőben, majd szobahőmérsékleten, szárazon tartott $(\mathrm{H})$ vesszők eredményei között, de a különbség még mindig nem volt szignifikáns (62. ábra - következő oldal teteje). 


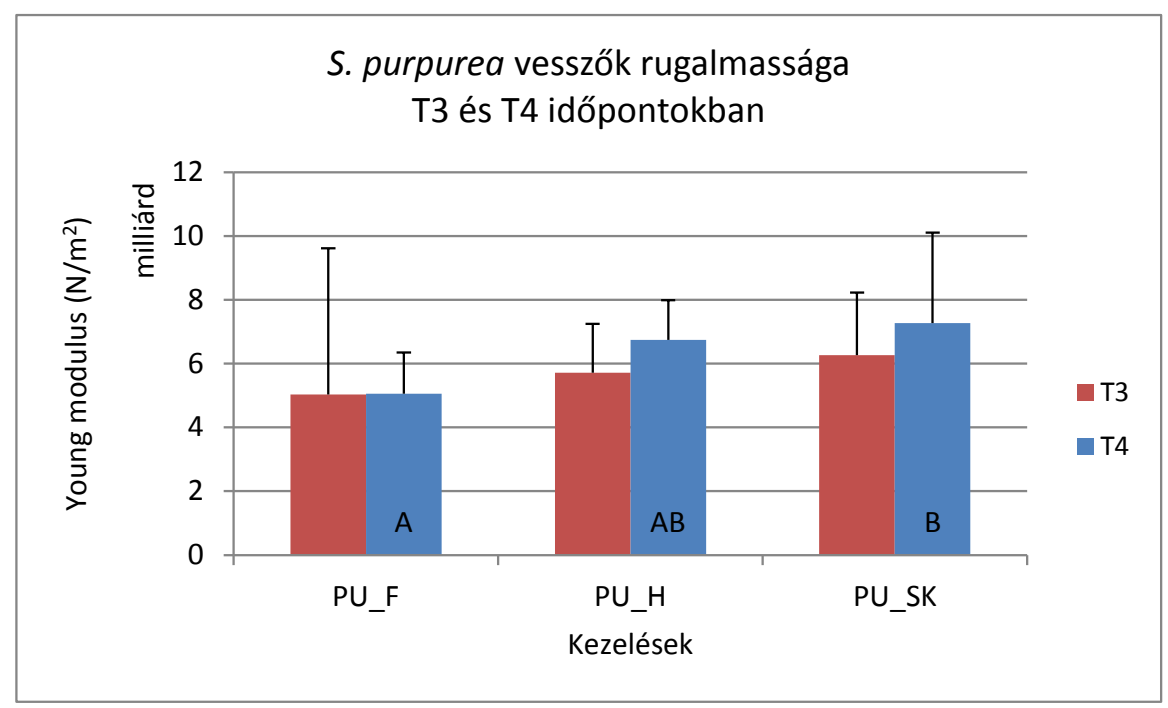

62. ábra: $S$. purpurea vesszők rugalmassága a 3. és a 4. mérési időpontban

16 héttel a kezeléseket követően, a hatodik mérési időpontban már csak a glicerinnel felszívatott vesszők eredményei különültek el szignifikánsan a többi kezelés eredményeitől. Egyértelműen a glicerinnel kezelt vesszők rugalmassági modulusa maradt a legalacsonyabb. A száraz kontroll, valamint a folyamatosan, illetve csak kezdetben hütöben tartott vesszők eredményei között szignifikáns különbség nem volt kimutatható. A diagramról (63. ábra) leolvasható, hogy ebben az időpontban már a kezdetben hütőben tartott, majd onnan kivett, és szobahőmérsékleten, szárazon tárolt vesszők Young-modulus értékei a száraz kontroll vesszők értékeinél is magasabbak lettek, és a folyamatosan hütőben tartott vesszők értékei is megközelítették a szobahőmérsékleten tartott száraz kontroll vesszők értékeit.

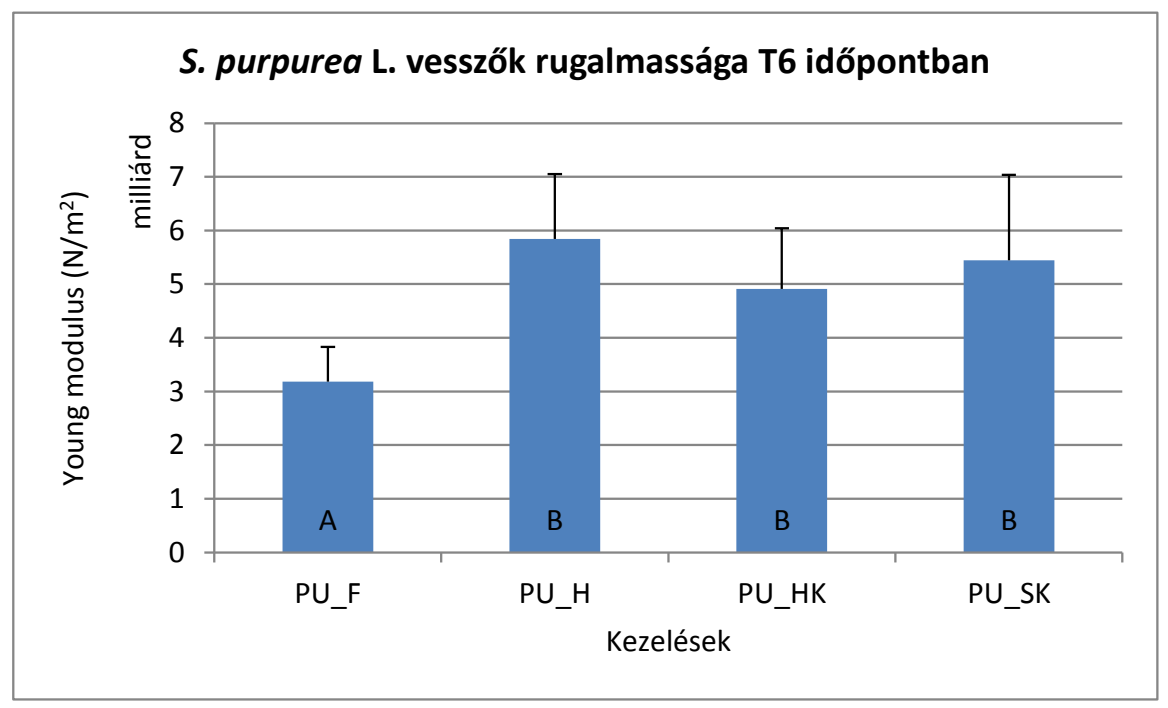

63. ábra: $S$. purpurea vesszők rugalmassága a 6. mérési időpontban

\section{A kezelések hatásának alakulása az idő folyamán és az eredmények kvantitatív érté- kelése $S$. purpurea vesszők esetén}

A glicerinnel felszívatott vesszők Young-modulus értékei az összes mérési időpontban alacsonyak maradtak. A kezdetben hütőben, majd szobahőmérsékleten, szárazon tartott vesszők 
Young-modulus értékei folyamatosan növekedtek, de lassabb ütemben, mint a száraz kontroll vesszők értékei. Szignifikáns különbség az első időpontban mért eredményektől a negyedik mérési időpontban volt kimutatható. A folyamatosan hütőben tartott kontroll vesszők rugalmassági modulusa az első négy mérési időpontban közel azonos volt, és csak az utolsó mérési időpontban bizonyult az előzőeknél szignifikánsan magasabbnak. A száraz kontroll vesszők eredményeinek tendenciózus növekedése a második és a negyedik mérési időpont között volt szembetűnő.

\section{Kezelések hatása $S$. purpurea vesszők morfológiai paramétereire}

A kísérlet beállítását követő hatodik napon a kontroll száraz vesszők mérésekor azokról szálanként átlagosan 1,15 db barka esett le. A kilencedik napra a szárazon tartott vesszők összeszáradtak, a kéreg ráncossá vált a héj alatti lécektől, melyek a vesszők kiszáradásával egyidejüleg kidudorodtak. A barkák mérete csökkent, és a vesszővel bezárt szögük nőtt. A vesszők színe az első mérési időpontban nem változott, a glicerinnel felszívatott (F kezelés), és a száraz kontroll (SK kezelés) vesszők esetében egyaránt ugyanolyan maradt.

A harmadik mérési időpontban a kontroll száraz vesszők változásai még szembetűnőbbek voltak: a barkák a vesszőkre közel merőlegese álltak, hosszuk az oldatban lévő barkák hosszának kétharmadára csökkent. A vesszők szárazak, tapintásra merevek voltak. Átlagosan újabb 4,03 db barka/vessző, a negyedik méréskor további 3,35 db barka/vessző hullott le.

Az első mérési időpontban a glicerines felszívató oldat pH értéke: 4,8 volt. A vesszőszín az oldatban nem változott. A harmadik mérési időpontban azt tapasztaltam, hogy a glicerinnel kezelt vesszők tapintásra, és kézzel való hajlítási próba alapján is teljesen rugalmasak voltak, barkák egyáltalán nem hullottak róluk.

A tíz napja hütőben lévő vesszőknél (H és HK kezelés) a vesszőszín fényes piros maradt. A barkák egyáltalán nem hullottak, csak egy-két száraz rügypikkely esett le.

A kezdetben hütőben tárolt, majd onnan kivett vesszők a harmadik mérési időpontban már szárazak voltak, érintésre hullottak róluk a barkák.

Az utolsó, hatodik mérési időpontban a hütőben tartott kontroll vesszőkön a barkák teljesen puhák maradtak, hajlíthatók voltak. Letörni csak kifejezetten erősen lehajlítva lehetett a barkákat. Ezzel szemben a glicerinnel felszívatott vesszőkről egyáltalán nem törtek le a barkák, még erős behatásra sem, a vesszők színe fényes zöldes barna (sötét bordó) maradt. A száraz kontroll vesszők teljesen kifakultak. A hütőben tartott kontroll vesszőkön felfedezhetők voltak a kéreg alatti hosszanti lécek, de alig domborodtak elő, mert ezek a vesszők kevésbé száradtak össze. 


\subsubsection{Salix rosmarinifolia vesszők tartósításának eredményei A rugalmassági modulus alakulása}

Az első mérési időpontban a kezelések hatása között még nem volt kimutatható szignifikáns differencia, a szárazon tartott kontroll (SK) vesszők rugalmassági értékei már ekkor szignifikánsan nőttek (64. ábra). Ekkor még tartott a két hétig tervezett felszívatás (F2 kezelés), így a felszívatás időtartama nem okozhatta a különbséget. A mért erőkből kiszámított rugalmassági modulusok ugyanakkor némileg alacsonyabbak (rugalmasabbak) lettek a két hétig tervezett felszívatáshoz használt oldatból kivéve (F2 kezelés), mint F1 kezelés esetén.

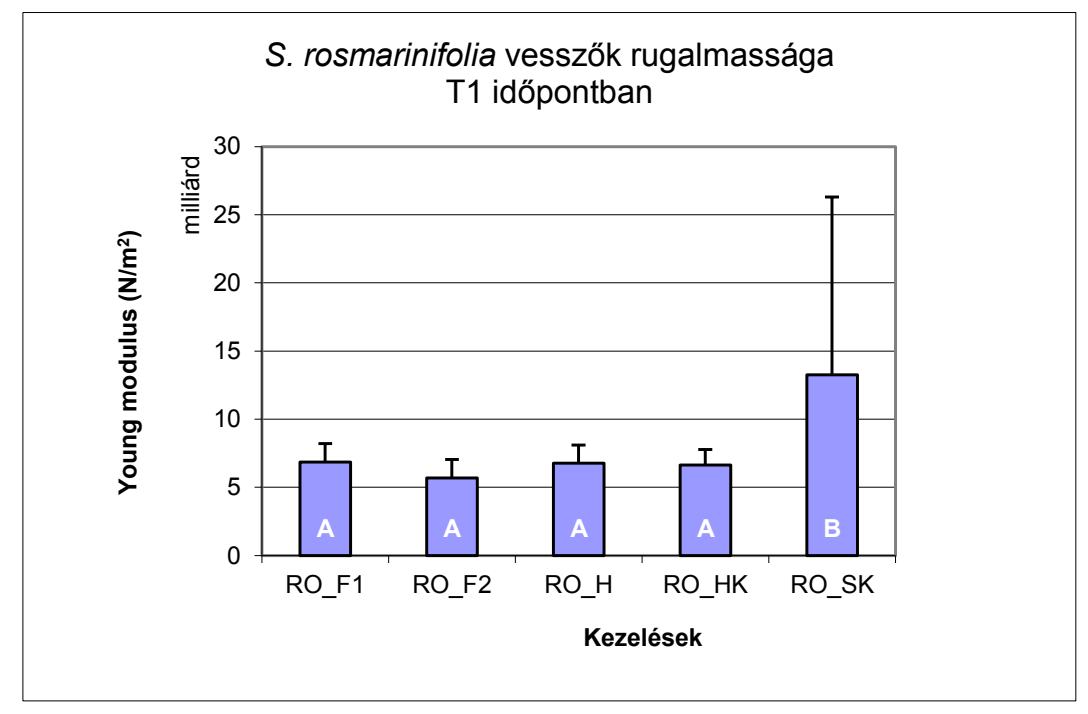

64. ábra: $S$. rosmarinifolia vesszők rugalmassága az 1. mérési időpontban

A második mérési időpontban magasabb Young-modulus értékeket kaptam H és SK kezelések esetében, és e kettő között már nem volt szignifikáns különbség. E kettőtől viszont szignifikánsan különbözött a másik három kezelés, azaz a kétféle glicerines felszívatás (F1 és F2 kezelések), és a folyamatosan a hütőben lévő vesszők (HK kezelés). Ez utóbbi három kezelés között nem volt kimutatható szignifikáns különbség. Az oszlopdiagramon (65. ábra - következő oldal teteje) az is jól látszik, hogy a két héten keresztül felszívatott vesszők eredményei (F2) itt is, mint az első mérési időpontban, alacsonyabb értékeket mutattak. A folyamatosan hủtőben tartott vesszők (HK kezelés) rugalmassági értéke a kétféle felszívatás eredményeként kapott értékek között helyezkedett el. 


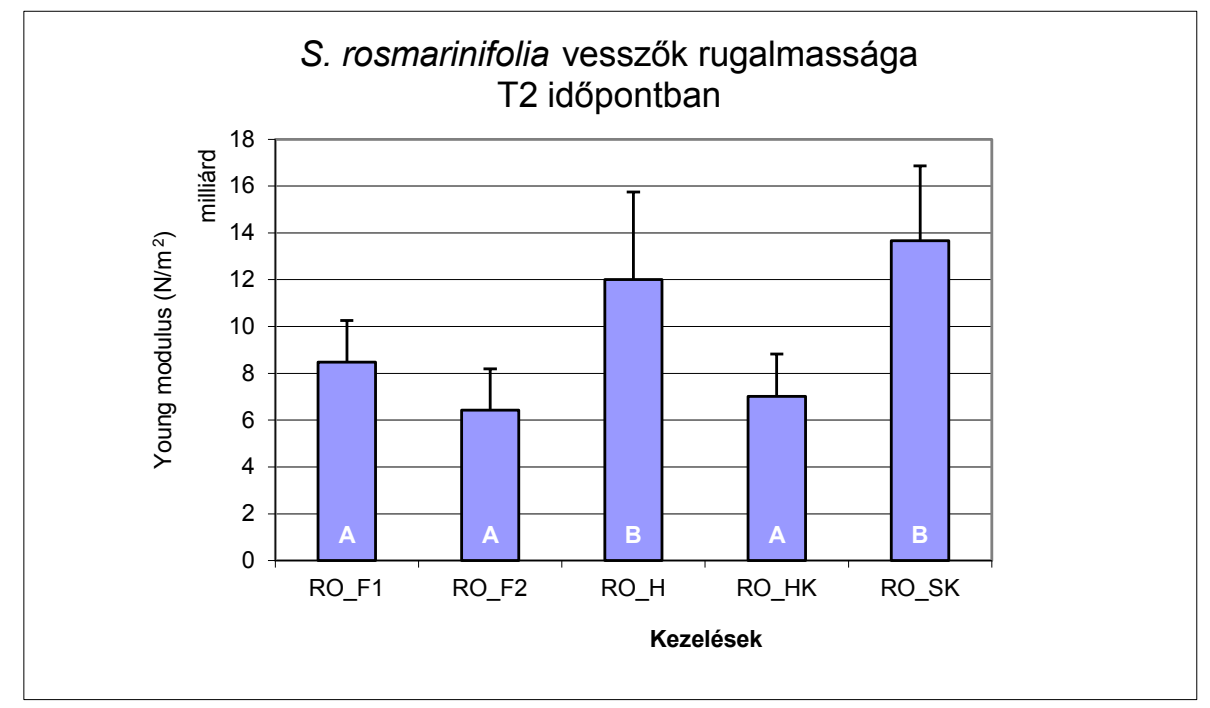

65. ábra: $S$. rosmarinifolia vesszők rugalmassága a 2. mérési időpontban

A harmadik mérési időpontban kezdett szignifikánsan is szétválni a különböző kezelések hatása. Legmagasabb Young-modulus értékeket a száraz kontroll (SK) és a kezdetben hütőben, majd szobahőmérsékleten tartott vesszők $(H)$ produkáltak, vagyis ezek voltak a legkevésbé rugalmas vesszők, és ezek között most sem volt kimutatható szignifikáns különbség. E két kezelés eredményeitől szignifikánsan különbözött a két hétig tartó glicerines felszívatás (F2 kezelés) hatása a vesszők rugalmasságára, mely a legalacsonyabb Young-modulus értékeket mutatta, azaz ezek a vesszők maradtak a legrugalmasabbak. A száraz kontrolltól (SK) szignifikánsan különböztek az egy hétig felszívatott (F1 kezelés) vesszők is, annál jelentősen alacsonyabb értékekkel, ugyanakkor a kezdeti hütőben való tárolástól (H kezeléstől) nem volt szignifikánsan elkülöníthető, bár annál alacsonyabb Young-modulus értékeket (rugalmasabb vesszőket) sikerült ezzel a kezeléssel elérnem (66. ábra).

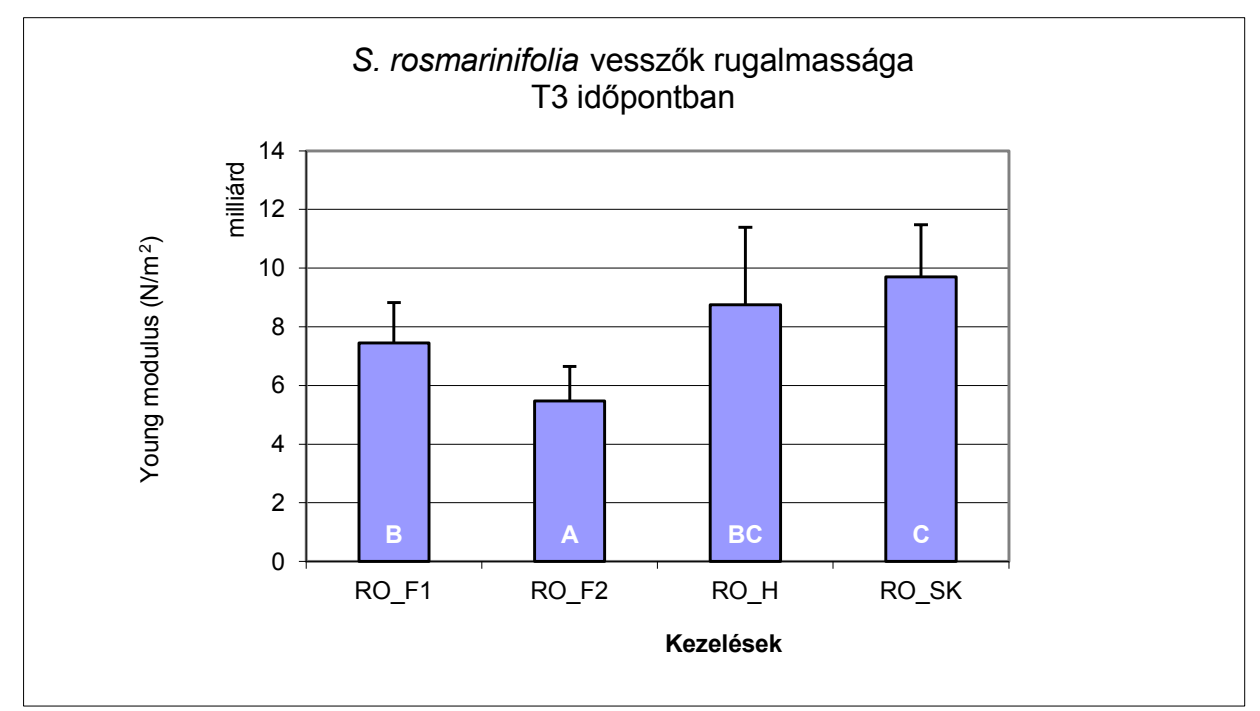

66. ábra: $S$. rosmarinifolia vesszők rugalmassága a 3. mérési időpontban

A negyedik mérési időpontban a kétféle glicerines felszívatás egymástól nem, azonban a száraz kontroll és a kezdetben hűtött, majd szobahőmérsékleten tartott vesszőktől (SK és H keze- 
lésektől) szignifikánsan eltért, a vártnak megfelelően azoknál alacsonyabb Young-modulus értékekkel. Ez utóbbi két kezelés (SK és H) között itt sem volt kimutatható szignifikáns különbség.

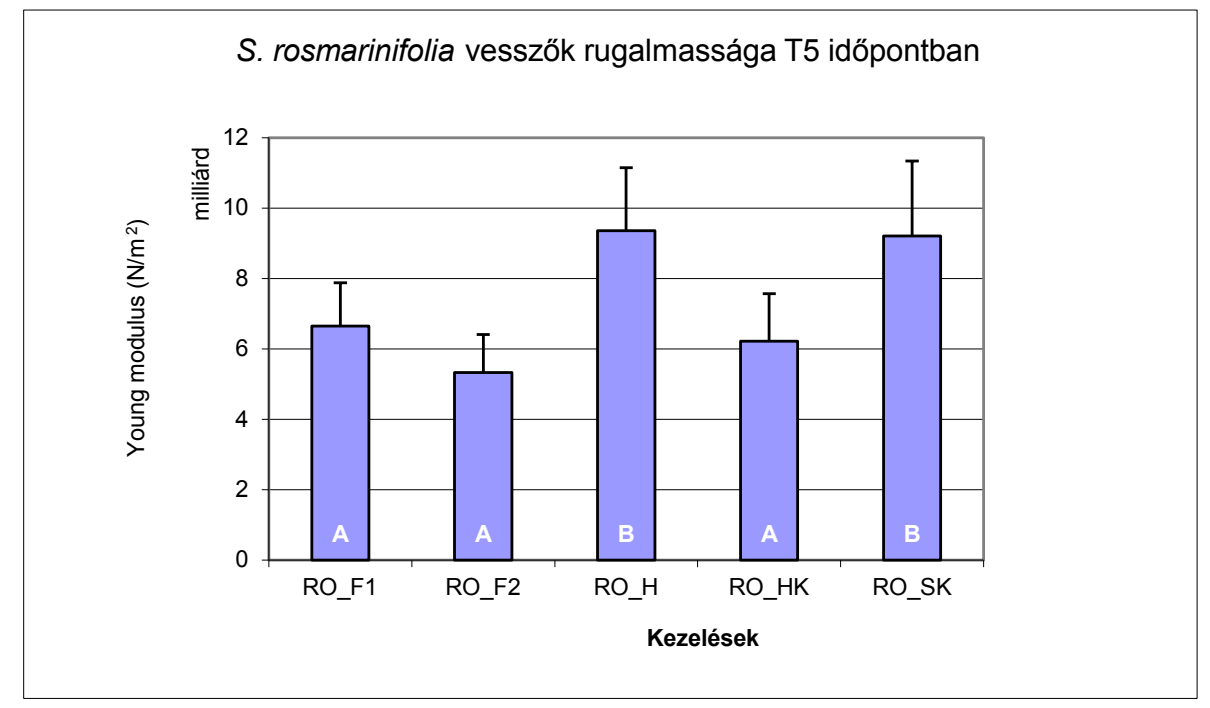

67. ábra: $S$. rosmarinifolia vesszők rugalmassága az 5. mérési időpontban

A következö, ötödik mérési időpontban is egyértelmủen elkülönültek a kontroll, a szárazon és a szobahőmérsékleten tartott vagy kezdetben hütőben, és a későbbiekben szobahőmérsékleten tartott vesszők, és a kétféleképpen felszívatott, valamint folyamatosan hütőben tárolt vesszők Young-modulus értékei. Az ötféle kezelés hatása tehát kettő, szignifikánsan elkülönülő csoportba volt sorolható: A-val jelöltem a diagramon (67. ábra) az oszlopokon az egymástól jelentősen nem különböző, alacsony Young-modulus értékeket tartalmazó, azaz kellően rugalmas vesszőket. A kiszáradt, magas Young-modulus értéket eredményező vesszőket jelölő oszlopok, vagyis a kezdetben hütött $(\mathrm{H})$, valamint a folyamatosan szobahőmérsékleten, szárazon tartott (SK) veszszők B betüjelet kaptak, szignifikánsan magasabb rugalmassági értékük alapján. Az alacsonyabb értékeknél tapasztalható kisebb eltérések alapján rugalmasság szerint a következő sorrendet lehetett felállítani a kezelések között (csökkenő rugalmasság szerint): két héten keresztül felszívatott (F2); folyamatosan hütőben tartott (HK); és végül az egy hétig felszívatott (F1) vesszők.

Az utolsó, hatodik mérési időpontban az eredményekben kimutatható eddigi különbségek jelentősen nem változtak, csak még árnyaltabbá váltak. Legalacsonyabb értékeket a két hétig tartó glicerines felszívatás (F2 kezelés) esetén kaptam, és ezek a számok szignifikánsan különböztek az egy hétig tartó glicerines felszívatás (F1 kezelés) eredményeitől. Az előző mérésektől eltérően itt már a folyamatosan hütőben tartott vesszők (HK) értékei lettek magasabbak az egy hétig glicerinnel felszívatott vesszők (F1) értékeinél, de ez a különbség még nem volt szignifikáns. Legmagasabb Young-modulus értékeket a kezdetben hütőben, majd szobahőmérsékleten, szárazon tartott vesszők esetén (H kezelésnél) kaptam, melyek ebben a mérési időpontban a többi kezelés eredményétől szignifikánsan különböztek. Második legmagasabb értékeket a szoba- 
hőmérsékleten, szárazon tartott kontroll (SK) vesszőknél kaptam. A folyamatosan hütőben tartott vesszők (HK kezelés) esetében alacsonyabb, de szignifikánsan nem különböző értékeket kaptam.

\section{A kezelések hatásának alakulása az idő folyamán és az eredmények kvantitatív érté-}

\section{kelése $S$. rosmarinifolia vesszők esetén}

A glicerinnel felszívatott vesszők (F1 és F2 kezelések) alacsony Young-modulus értékei között a különböző mérési időpontokban nem volt jelentős eltérés. A legelső és az utolsó mérési időpontban sem volt szignifikáns a különbség. A szobahőmérsékleten, szárazon tartott kontroll vesszők (SK kezelés) mérésekor minden mérési időpontban viszonylag magas Young-modulus értékeket kaptam. A kezdetben hütőben, majd szobahőmérsékleten, szárazon tartott vesszők (H kezelés) Young-modulus értékei fokozatosan nőttek, ahogy a hűtő-tárolóból kivett vesszők lassan kiszáradtak. A folyamatosan hütőben tartott vesszők (HK kezelés) mérésekor kapott értékek mindvégig az alacsonyabb tartományban mozogtak. Az utolsó mérési időpontban magasabbak lettek, ami a vesszők kismértékü kiszáradására utal, de ez a különbség nem volt szignifikáns.

\section{Kezelések hatása $S$. rosmarinifolia vesszők morfológiai paramétereire}

Az első mérési időpontban a kontroll száraz vesszők még tartották sárga színüket, ugyanekkor a felszívató oldatban lévők besötétedtek, barnás árnyalatúvá váltak (68. ábra). A kontroll vesszők merevek, szárazok lettek. A barkák is összeszáradtak, de ez önmagában nem volt feltünő, csak a felszívató oldatban (F2 kezelés) lévő, nem megnyúlt, ép barkákkal összehasonlításban lehetett érzékelni, hogy azoknál kisebbek. A barkák nem hullottak.

Az egy hetesre tervezett kezelés (F1) felszívató oldatában álló, fóliával is beburkolt vesszők színében a felszívatás kezdetétől számított negyedik napon volt megfigyelhető különbség: a fóliában még zöldessárgák maradtak, a fólia nélkül felszívató oldatban állók már egészen barnák lettek. A felszívatás kezdetétől számított hatodik napon a felszívató oldatba érő szárrészek élénk zöldessárgák maradtak, az oldat felszíne felett, a vázában szabadon álló szárrészek sötétbarnák lettek. A váza pereme felett a fóliával burkolt szárrészek a száraz kontrollhoz képest kevésbé, de a felszívató oldatban szabadon álló (F2) vesszőkhöz képest jobban tartották a színüket. A fólia alatt megpattantak a hajtásrügyek, és a bar-
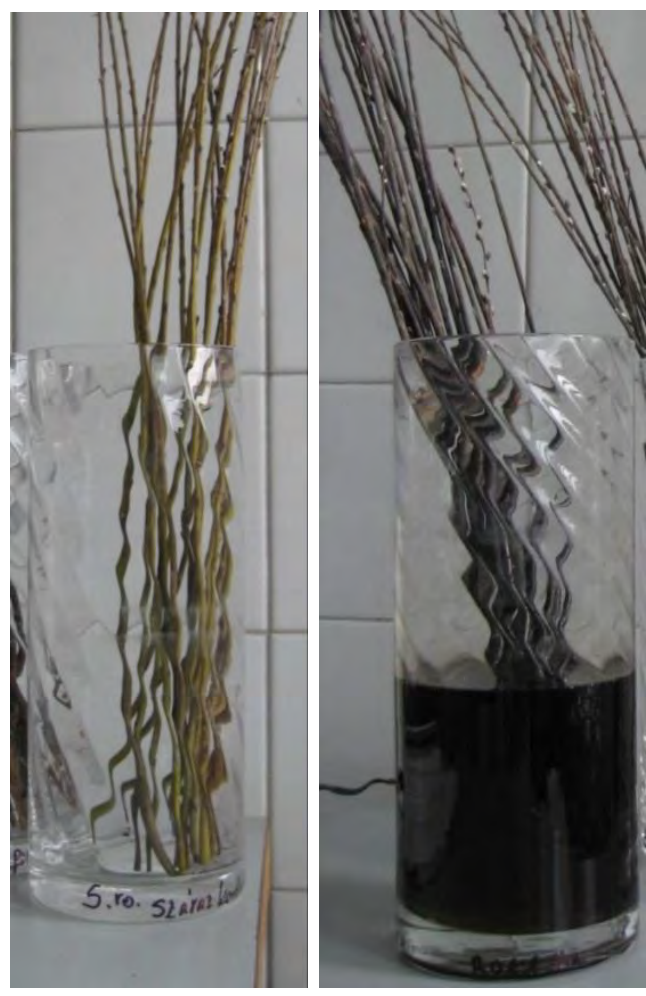

68. ábra: Szárazon tartott és glicerinnel felszívatott $S$. rosmarinifolia vesszők (fotó: Treerné, 2008) 
kák a felszívató oldatban szabadon álló vesszők (F2) barkáihoz képest megnyúltak. A felszívató oldatban lévő vesszők körüli fólia bepárásodott a megnövekedett relatív páratartalom következményeként, és a fóliához hozzáérő barkákon megjelent a glicerin barnás cseppek formájában. A barkák átlagosan 7,13 mm hosszúra nyúltak. A rügypikkelyek és a takarásukból kilátszó barkák aránya $1: 2,5$ volt.

Az egy hétig felszívatott, fóliával burkolt, a glicerines oldatból kivett vesszőkön a barkák megnyúltak, teljesen felszívták a glicerint. A barkák túlzott glicerin felvételét az is mutatta, hogy azokat megfogva összenyomhatóakká váltak, és a barna színü felszívató oldat kipréselődött belölük. A glicerines oldat nem csak a barkák (a füzér tengelye és a murvapikkelyek) friss víztartalmát helyettesítette, hanem kivált a murvapikkelyek között is. A megnyúlt, glicerinnel telített barkák könnyen, mozgatásra lehullottak a tövükön lévő rügypikkelyekkel együtt.

A fóliázás nélkül felszívató oldatban álló vesszők már a kísérlet beállítását követő negyedik napon barnára, a hatodik napra sötétbarnára színeződtek, a száraz kontroll vesszők sárgák maradtak. A felszívató oldat is sötétebbé, barna színűvé vált. Ugyanakkor ugyanez az oldat áttetsző maradt abban a vázában, melyben a vesszőket fóliába burkoltam. A barkák átlagosan 4,06 mm hosszúak voltak. A rügypikkelyek, és a takarásuk alól kilátszó barkák aránya 1:1 volt.

Az első mérési időpontban a hütéssel kezelt vesszők színe a frissen vágott anyaggal megegyező maradt. Sem a barkák, sem a fennmaradt rügypikkelyek nem hullottak. Az utolsó mérési időpontban a hütött kontroll vesszőknél azt tapasztaltam, hogy azok tapintásra viszonylag rugalmasak, a barkák puhák maradtak. A vesszőszín kevésbé fakult meg, 16 hét elteltével a sárga részek zöldes árnyalatúvá, a piros részek barna színűvé változtak.

\subsubsection{Salix vesszők víztartalmának és víz-helyettesítési faktorának (Z- érték) meghatározása}

Az első 48 órás szárítást követően a második kezelés hatására a vesszők már nem veszítettek többet a súlyukból, a szárítóból kivéve a laboratóriumban uralkodó relatív páratartalomnak köszönhetően kismértékben nőtt is. A kötegek friss, szárított, és a szárítást követő időpontokban mért tömegét részletesen a 11. táblázat és a 12. táblázat tartalmazza.

11. táblázat: $S$. caprea vesszők tömege frissen és szárító kezelés hatására

\begin{tabular}{|l|l|l|l|}
\hline \multicolumn{1}{|c|}{ Salix caprea } & \multicolumn{1}{|c|}{ Kötegek tömege (g) } & Szárazanyag (\%) & Víztart. (\%) \\
\hline Friss köteg: & 52,4 & & \\
\hline 48 órás szárítás után: & 18,27 & 34,87 & 65,13 \\
\hline Szárítóból kivéve + fél nap: & 18,43 & 35,17 & 64,83 \\
\hline plusz 2 nap & 18,58 & 35,46 & 64,54 \\
\hline plusz 1 hét & 18,71 & 35,71 & 64,29 \\
\hline plusz 2 hét & 18,95 & 36,16 & 63,84 \\
\hline
\end{tabular}


12. táblázat: $S$. rosmarinifolia vesszők tömege frissen és szárító kezelés hatására

\begin{tabular}{|l|l|l|l|}
\hline \multicolumn{1}{|c|}{ Salix rosmarinifolia } & Kötegek tömege (g) & Szárazanyag (\%) & Víztart. (\%) \\
\hline Friss köteg: & 9,85 & & \\
\hline 48 órás szárítás után: & 4,83 & 49,04 & 50,96 \\
\hline Szárítóból kivéve + fél nap: & 4,87 & 49,44 & 50,56 \\
\hline plusz 2 nap & 4,9 & 49,75 & 50,25 \\
\hline plusz 1 hét & 4,94 & 50,15 & 49,85 \\
\hline plusz 2 hét & 4,99 & 50,66 & 49,34 \\
\hline
\end{tabular}

A $S$. caprea és a $S$. rosmarinifolia kötegek esetében is elegendő volt 48 órás szárítás, további szárítással már nem lehetett még több vizet kivonni a növényekből. A szárítást követő enyhe növekedés a vesszők súlyában az idő múlásával abból adódott, hogy a laboratórium levegőjéből a teljesen kiszárított vesszők nedvességet vettek fel, míg be nem állt egy egyensúlyi állapot (69. ábra).

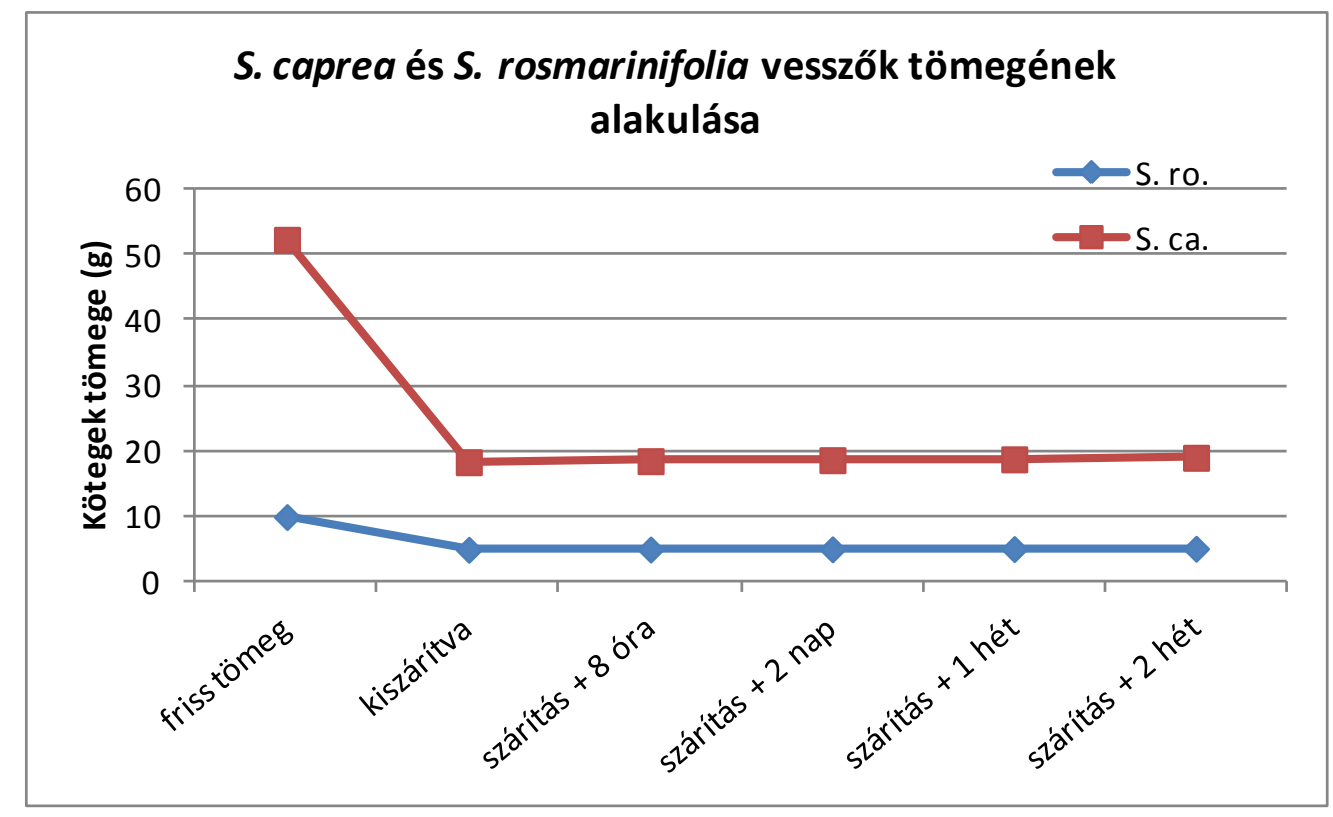

69. ábra: $S$. caprea és $S$. rosmarinifolia vesszők friss és szárítást követő tömegének alakulása

Két hétig nőtt a vesszők súlya, ezért ezt a végső, egyensúlyi állapotot vettük alapul a víz-, illetve szárazanyag tartalom megállapításához. Ezek alapján a $S$. caprea vesszők víztartalma 63,83\%, a S. rosmarinifoia vesszők víztartalma 49,33\% volt. A Z-érték számításhoz ezekből az adatokból indultunk ki.

A szárítószekrényből kivett $S$. caprea vesszők esetében nem csak a tömeg változása jelezte a vízveszteséget, hanem a vessző színe is, mely friss zöldből barna színűvé változott, és a száradás következtében jól látszottak a kidomborodó kéreg alatti lécek. A glicerines felszívató oldatban a vesszők zöld színűek, a kéreg ép, sima maradt, nem száradt össze, ezért a kéreg alatti lécek sem domborodtak ki (70. ábra - következő oldal). A barkák átlagos mérete a tartósított vesszőkön (hossz x szélesség): 26,81 mm x 15,34mm, a szárító kezelésben részesített vesszőkön: 15,95 


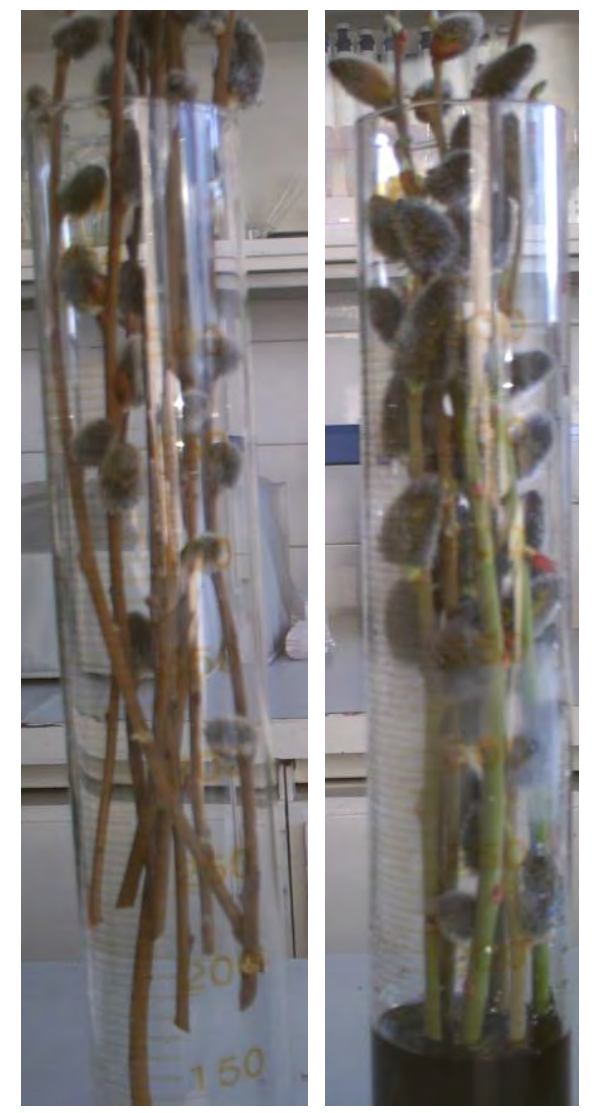

70. ábra: $S$. caprea vesszők szárító és tartósító kezelést követően (fotó: Treerné, 2013) mm x 7,85 mm volt. Az összeszáradt barkák mérete hosszirányban 40,5\%-kal, szélességük 48,8\%-kal csökkent, azaz a kiszáradás nem csak jól látszott, de az elvégzett mérések is igazolták.

A S. rosmarinifolia vesszők a szárítószekrényből kivéve látszólag kevésbé különböztek a tartósító oldatban lévő vesszőktől, érintésre azonban hullottak róluk a barkák, és érezhetően szárazabbak, merevek, törékenyek lettek. A glicerines oldatban a vesszők hajlékonyak maradtak, a barkák nem hullottak.

A tartósító oldatba állított vesszők folyadék-felvételét, a mérőhengerekről leolvasott folyadékszinteket, és az ezekből számított fogyási adatokat a 13. táblázat tartalmazza.

A tartósító oldatból összesen 16 nap alatt egy köteg $(49,85 \mathrm{~g}) S$. caprea $15 \mathrm{~cm}^{3}$, egy köteg $S$. rosmarinifolia $(8,13$ g) $6 \mathrm{~cm}^{3}$ mennyiséget vett fel. A folyadék felvételének időbeli eloszlását a következő oldal tetején látható grafikon illusztrálja (71. ábra). A S. rosmarinifolia vesszők a kísérlet beállítását követően két nap alatt az összes felvett oldat 33,3\%-át, öt nap alatt 58,3\%-át, hat nap alatt $66,6 \%$-át, nyolc nap alatt 75\%-át vették fel, a maradék $25 \%$-ot a második nyolc nap alatt. A $S$. caprea vesszők az első két nap alatt az összes felvett oldat 33,3\%-át, öt nap alatt 40\%-át, nyolc nap alatt 46,6\%-át vették fel. A maradék 53,4\% a második nyolc nap alatt fogyott el.

13. táblázat: $S$. caprea és $S$. rosmarinifoia vesszők folyadék-felvétele a glicerines tartósító oldatból

\begin{tabular}{|c|c|c|c|c|}
\hline \multirow{2}{*}{$\begin{array}{l}\text { Tartósító oldat } \\
\qquad\left(\mathrm{cm}^{3}\right):\end{array}$} & \multicolumn{2}{|c|}{ S. caprea } & \multicolumn{2}{|c|}{ S. rosmarinifolia } \\
\hline & $\begin{array}{c}\text { Mérö- } \\
\text { hengerben }\end{array}$ & Fogyás & $\begin{array}{c}\text { Mérö- } \\
\text { hengerben }\end{array}$ & Fogyás \\
\hline beállításkor & 160 & 0 & 23 & 0 \\
\hline 2 nap múlva & 155 & 5 & 21 & 2 \\
\hline 5 nap múlva & 154 & 6 & 19,5 & 3,5 \\
\hline 6 nap múlva & 154 & 6 & 19 & 4 \\
\hline 8 nap múlva & 153 & 7 & 18,5 & 4,5 \\
\hline 16 nap múlva & 145 & 15 & 17 & 6 \\
\hline
\end{tabular}




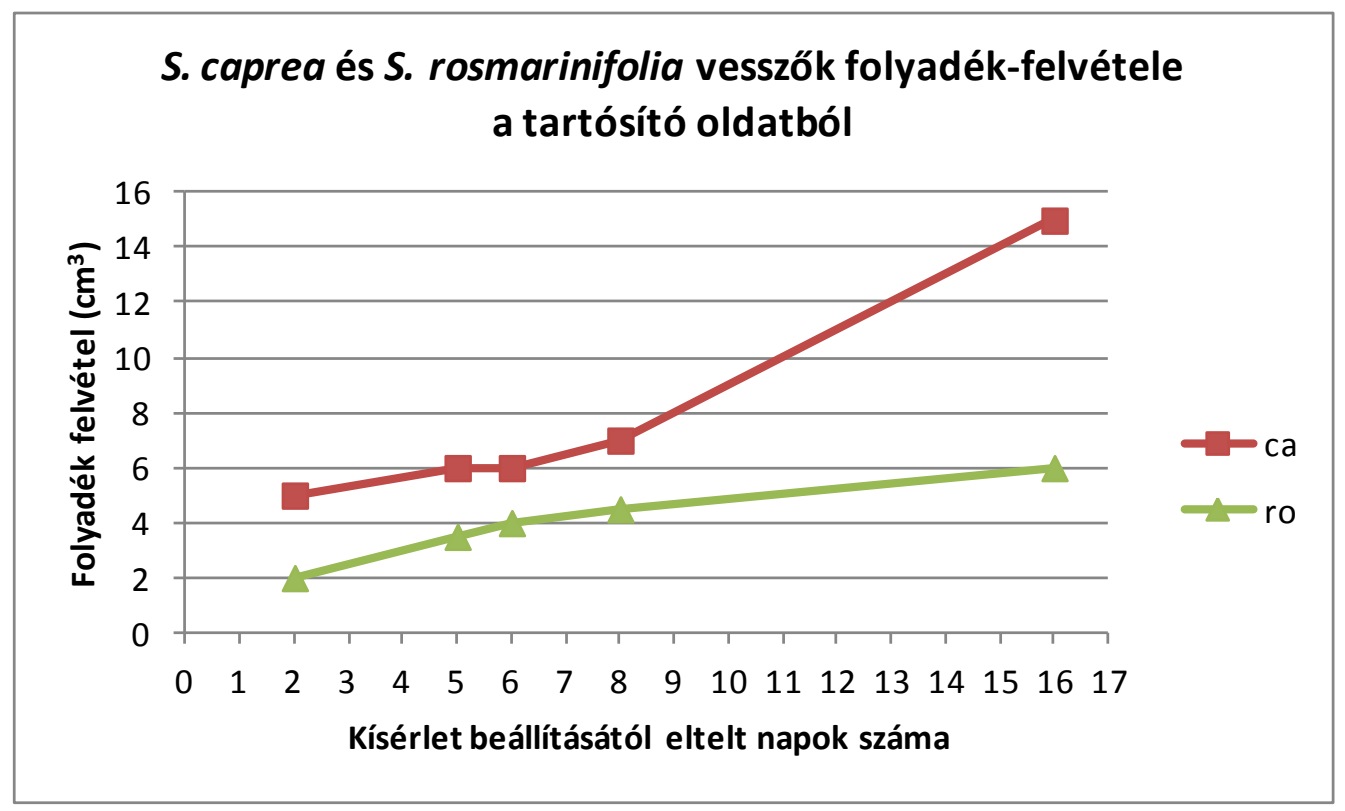

71. ábra: $S$. caprea és $S$. rosmarinifolia vesszők folyadék-felvételének alakulása az időben

A tartósító oldatba állított $S$. caprea vesszők kezdeti átlagos tömege 49,85 g volt, mely a felszívatást követően 28,34 g-ra változott, a S. rosmarinifolia vesszők kezdeti átlagos tömege 8,13 g volt, mely a felszívatást követően 7,75 g-ra változott. A tartósító oldat glicerintartalmának, az oldatból felvett mennyiségek, és az oldat sürüségének ismeretében kiszámoltuk az egyes kötegek által ténylegesen felvett glicerin mennyiségét. A kötegek friss tömegének, és ezen belül a víztartalom százalékos arányának ismeretében, a felvett glicerin mennyisége alapján az Irodalmi áttekintés, valamint az Anyag és módszer fejezetben ismertetett módon kiszámoltuk a kétféle Z-értéket, mely $S$. caprea esetén $0,1981, S$. rosmarinifolia esetén 0,9927 . A részletes számadatokat az M18. melléklet (189. o.) tartalmazza. Tehát ennél a tartósítási kísérletnél a $S$. caprea esetében a barkás vesszők friss víztartalmának közel 20\%-a, a S. rosmarinifolia vesszőknél a friss víztartalom 99\%-a cserélődött ki glicerinre.

A glicerines felszívatást követően a $S$. caprea vesszők súlya az eredeti súly 56,84\%-ára, a S. rosmarinifolia vesszők súlya az eredeti súly 95,33\%-ára csökkent. Ez egybevág a kiszámított Z-értékekkel, melyek közül a S. caprea esetében kapott 19,81\% nem elégséges a vesszők megfelelö tartósításához, a vesszők kiszáradtak. A S. rosmarinifolia vesszők esetében azonban az öszszes víztartalom 99\%-a glicerinre cserélödött, ez eredményezte azt, hogy a vesszők teljes mértékben megőrizték rugalmasságukat.

\section{6 Új tudományos eredmények}

A hazai flórából összesen hét, barkáikkal díszítő, a virágkötészetben felhasználható barkás vessző előállítás céljából termeszthető Salix taxont szelektáltam, melyek közül hat fajtajelölt 
leírása megjelent TóTH (2012) kézikönyvében. Elkészítettem az általam szelektált klónok részletes botanikai leírását, valamint hasznos adatokat szolgáltattam a növények fejlődésmenetéröl.

Elsőként írtam le (és publikáltam botanikai közleményben) a $S$. purpurea faj rügypikkelyének sajátos leválási módját, mely eltér a Salix nemzetségben általánosan jellemző rügypikkely leválási módtól.

Megállapítottam a szelektált klónok évenkénti vesszőhozamát, javaslatot tettem a $S$. rosmarinifolia kultúrában tartásának optimális hosszára. Felállítottam az egyes klónok esetén a barkás vesszők értékesítési méretkategóriáit.

A gyökereztetési kísérletek alapján megállapítottam, hogy a különlegesen dekoratív barkájú, rosszul gyökeresedő $S$. caprea CA1 klón és a $S$. rosmarinifolia RO3 klón dugványain az alkalmazott kezelésekkel kalluszképződés, illetve gyökérkezdemények fejlődése indukálható.

Kidolgoztam a $S$. caprea CA1 klón és a S. rosmarinifolia RO3 klón gyökereztetésének optimális módszerét, megállapítottam a gyökereztetés elősegítésére legmegfelelőbb serkentőszert, kezelési időtartamot, kezelési hőmérsékletet és a dugványszedésre alkalmas időpontot.

Összeállítottam a barkás vesszőként termesztett füz fajokon hazánkban leggyakrabban előforduló károsítók listáját, és kitértem ezek hatására a barkás vesszők tekintetében.

Elsőként végeztem $S$. rosmarinifolia rügyek nyugalmának megtörésére irányuló kísérletet, megállapítottam a vesszők nyílasztásához szükséges $\mathrm{GA}_{3}$ hormonkoncentrációt és a nyílasztás időtartamát.

Kidolgoztam a vesszők rugalmasságának számszerüsítésére szolgáló mérési módszert.

A rugalmasság számszerüsíthető mérésére szolgáló módszer segítségével bizonyítottam a Salix barkás vesszők glicerines tartósításának hatékonyságát. E módszer alkalmas lehet más különleges (fás szárú) vágott virágok tartósító kezeléseinek összehasonlítására, a kísérletek eredményeinek értékelésére.

Kidolgoztam három Salix faj vesszőinek tartósításához szükséges kezelési módszereket. Megállapítottam az egyes fajok esetében szükséges glicerines tartósító oldat megfelelő összetételét, valamint a felszívatás időtartamát. 


\section{KÖVETKEZTETÉSEK ÉS JAVASLATOK}

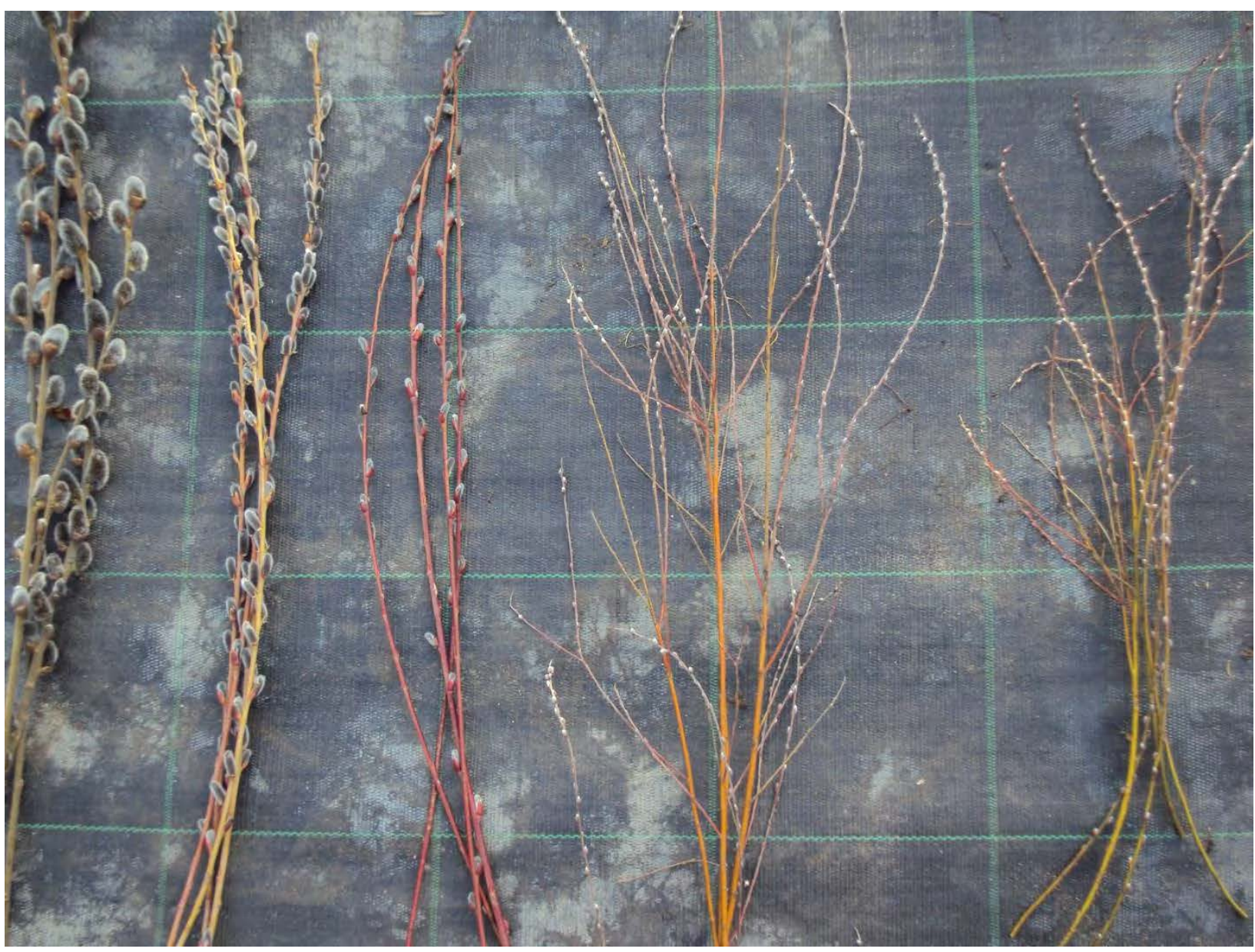

72. ábra: Salix klónok barkás vesszői (balról jobbra): CA1, PU2, PU2, RO1, RO2 (fotó: Treerné, 2010)

\subsection{Barkás vessző termesztés céljából szelektált Salix klónok}

Az általam szelektált Salix klónok mindegyike alkalmas barkás vessző (72. ábra) előállítás céljából való termesztésre, ezen túl kerti vagy közterületi kiültetésre is javasolhatók.

A S. caprea CA1, 'Big Black' fantázianevü klónt szoliternek érdemes ültetni nagyobb házikertbe. Parkokba rendkívül dekoratív barkái miatt csak olyan helyre ajánlott, ahol védve van a gyüjtők általi illetéktelen levágástól (pl. bekerített, őrzött ipari parkok, gyárak zöldfelületei). Barkás vessző termesztés céljából a szaporítást gyökereztetési kísérletem alapján növényházban, serkentőszer alkalmazásával (6\% NES por formában vagy legalább félórás felszívatás Kelpakkal) célszerü végezni kora tavasszal, vagy akár a januári faiskolai holt időszakban. Melegtalp alkalmazása nem szükséges. A gyökeres növényeket tavasszal vagy nyár elején (a faiskolai munkacsúcs időszakán kívül) lehet becserepezni, és ősszel kiültetni szabadföldre (tenyészterület: 1 x 2,5 m), az időjárástól függően akár november végéig. Már az egy éves tövekről szedhető piacképes áru, jelentősebb bevételt a növények két éves korától lehet elérni, mikor már extra méretü (120-150 cm hosszú) vesszők is fejlődnek. A növényeket minden évben vissza kell vágni 
a megfelelő minőségű vesszők fejlődése érdekében. A barkás vesszők betakarítása általában februárban vagy március első felében időszerü, a hőmérséklet aktuális változásának függvényében. Különös odafigyelést igényel a megfelelő stádiumú virágzatokkal berakódott vesszők szedése, mert egy tél végi, kora tavaszi váratlan felmelegedés következtében két-három nap alatt annyit fejlődhetnek a barkák, hogy azokból már nem szedhető piacképes áru.

A két $S$. purpurea klón szintén dekoratív barkás vesszőket terem, különösen a PU2 klón fényes bordó vesszői díszesek. Rendkívül erős növekedésükből adódóan az egyes töveken a generatív részekkel azonos, vagy azoknál még nagyobb arányban fejlődnek vegetatív rügyekkel berakódott vesszők, ezért a betakarításkor és az áru válogatásakor (a másod- és harmadrendü elágazások levágásakor) nagy mennyiségü hulladék keletkezik. Évenkénti visszavágása elengedhetetlen, ez azonban, és különösen a barkás vesszők további levágása igen munkaigényes. Ezért barkás vessző előállítás céljából történő termesztése elsősorban olyan területen ajánlott, ahol rendelkezésre áll olcsó kézi munkaerő. Érdemes lenne vele további kísérleteket végezni, a növekedési erély csökkentésének céljából más füz alanyokra oltva akár magastörzsön nevelni.

S. rosmarinifolia klónok közül az RO1 klónnak volt a legnagyobb hozama a vesszők számát és méretét is tekintve. Ezt közelítette a bordó vesszőszínủ RO4 klón hozama, melynek habitusa és termete is hasonló a sárga vesszőjü RO1 klónhoz. Az RO2, azaz a 'Green Creeper' fantázianevü klón kúszó, legyökerező szárainak köszönhetően talajtakarónak alkalmas, hálószerü gyökérzetével a rézsűt is megköti. A gyöngybarka klónok közül ez adja a legrövidebb vesszőket, melyek a növény habitusából (oldalirányba növő, majd felfelé törő vesszők) adódóan enyhén hajlottak, ívesek. Ugyanakkor a különleges, élénkzöld vesszőszín, és a rövid szártagok miatt a vesszőkön fejlődő rengeteg apró barkának köszönhetően rendkívül dekoratív különleges vágott virág, kisebb tavaszi virágok (pl. jácint, tulipán) mellé csokorba is könnyen köthető. A legnagyobb termetü S. rosmarinifolia klón a RO3, fantázianevén a 'Straight Orange' volt, mely végleges méretét a szaporítást követő negyedik évben érte el. A klón barkás vesszőként történő felhasználásán túl házikerti kiültetésre is kiválóan alkalmas, minden évszakban látványos, dekoratív színfoltja a kertnek. Télen világító narancspiros vesszőivel, tavasszal lombfakadás előtt nyíló ezüstös barkáival, nyáron már messziről csillogó ezüstös lombjával, ősszel sárga lombszínével díszít. Ennél a narancsos vesszőszínü klónnál volt a legszembetünőbb, hogy a vesszők végleges színének kialakításában valószínűleg az intenzív besugárzás és az alacsonyabb hőmérséklet nélkülözhetetlen tényezők, a vesszők a téli hónapokban színeződtek a legszebben.

A dugványozást követő első évben egyetlen klón sem ad még igazán piacképes árut, ám visszavágásuk ekkor is szükséges. Megfelelő minőségü és mennyiségű áru a legalább két, inkább három éves tövekről szedhető. A tövenkénti vesszőhozam helyett lehetséges volna területre vetítve megadni ezt a számot, mert - különösen az intenzíven legyökeresedő, kúszó jellegű klón 
esetében - a tövek jelentősen gyarapodnak az évek folyamán. A terjedést a telepítési távolság meghatározásánál is célszerü figyelembe venni.

A S. rosmarinifolia klónok szaporítását feltétlenül növényházban javasolt végezni tél végén vagy kora tavasszal. Fásdugványt akár a levágott vesszők alsó, vegetatív részéből is vághatunk. Minél vastagabb, annál jobban gyökeresedik. Melegtalp alkalmazása kerülendő. Legjobb, ha sejttálcába dugványozunk. A később becserepezett, konténerben nevelt növényeket ősszel lehet kiültetni a faiskolába. Az alacsony termetű klónok esetében (pl. RO2) érdemes lenne még talajtakarásos termesztési kísérleteket végezni. Több gyomfaj ugyanis (elsősorban a Poaceae családból) a füzvesszők között megtelepülve túlnövi azokat, illetve az elszáradt kórók miatt a betakarítás, a vesszők szétválogatása válik munkaigényesebbé.

Eredményeim alátámasztják, hogy a Magyarországon honos cinegefüz igen perspektivikus növény a dísznövénytermesztés és -kereskedelem számára. A különböző ökotípusok, klónok között többféle habitusú és vesszőszínü növényt találunk, melyek egyrészt a kínálatot gazdagítják, másrészt egyéb növény termesztésére alkalmatlan - például ideiglenesen vízzel elárasztott területek hasznosítására is alkalmasak. A növényeket viszonylag kis méretük könnyen kezelhetővé teszi. Az áru betakarítása, feldolgozása, és szállítása a többi különleges vágott virághoz, különösen az egyéb barkafüz vesszőkhöz képest egyszerübb, ugyanakkor a vesszők értéke meghaladja azokét. A többféle klónnak köszönhető szélesebb választék pedig végképp olyan növénynyé teszi, mellyel feltétlen érdemes foglalkozni, akár kis termesztőterületen is. A faj genetikai változatossága révén perspektívikus nemesítési alapanyag, az előbbi szempontok pedig alkalmassá teszik arra, hogy gazdasági válság idején is kiegészítő keresetet biztosíthasson a termesztők részére.

\subsection{A melegtalp kezelés, a gyökereztető szerek és a dugványozás időpontjának hatása a gyökeresedésre}

Melegtalp alkalmazása mindkét faj esetében szükségtelennek bizonyult. A S. caprea dugványok melegtalp kezelés nélkül is kellően gyökeresedtek, csak a gyökeresedés hosszabb ideig tartott. A S. rosmarinifolia dugványainál a melegtalp alkalmazása kifejezetten károsnak bizonyult, a vékony dugványok még a járulékos gyökerek képződése előtt könnyen kiszáradtak, ezért ez utóbbi faj gyökereztetése során kerülendő. 


\subsubsection{Salix caprea CA1 klón gyökeresedése}

A dugványok szedésének és a dugványozás időpontjának tekintetében megállapítottam, hogy mindhárom időpontban szedett dugványok sikeresen gyökereztethetők, de a gyökeresedés ideje különböző, a decemberben szedett dugványok esetében a legelhúzódóbb.

A novemberi dugványozást követő első hetekben úgy tünt, a NES porral végzett kezelés a legeredményesebb a gyökereztetés szempontjából, a végső bonitálás eredményei alapján azonban (73. ábra) a gyökeresedés elösegítésére leginkább a Kelpak ${ }^{\circledR}-k a l$ nyolc órán keresztül végzett felszívatás ajánlható, melegtalp alkalmazása nélkül.

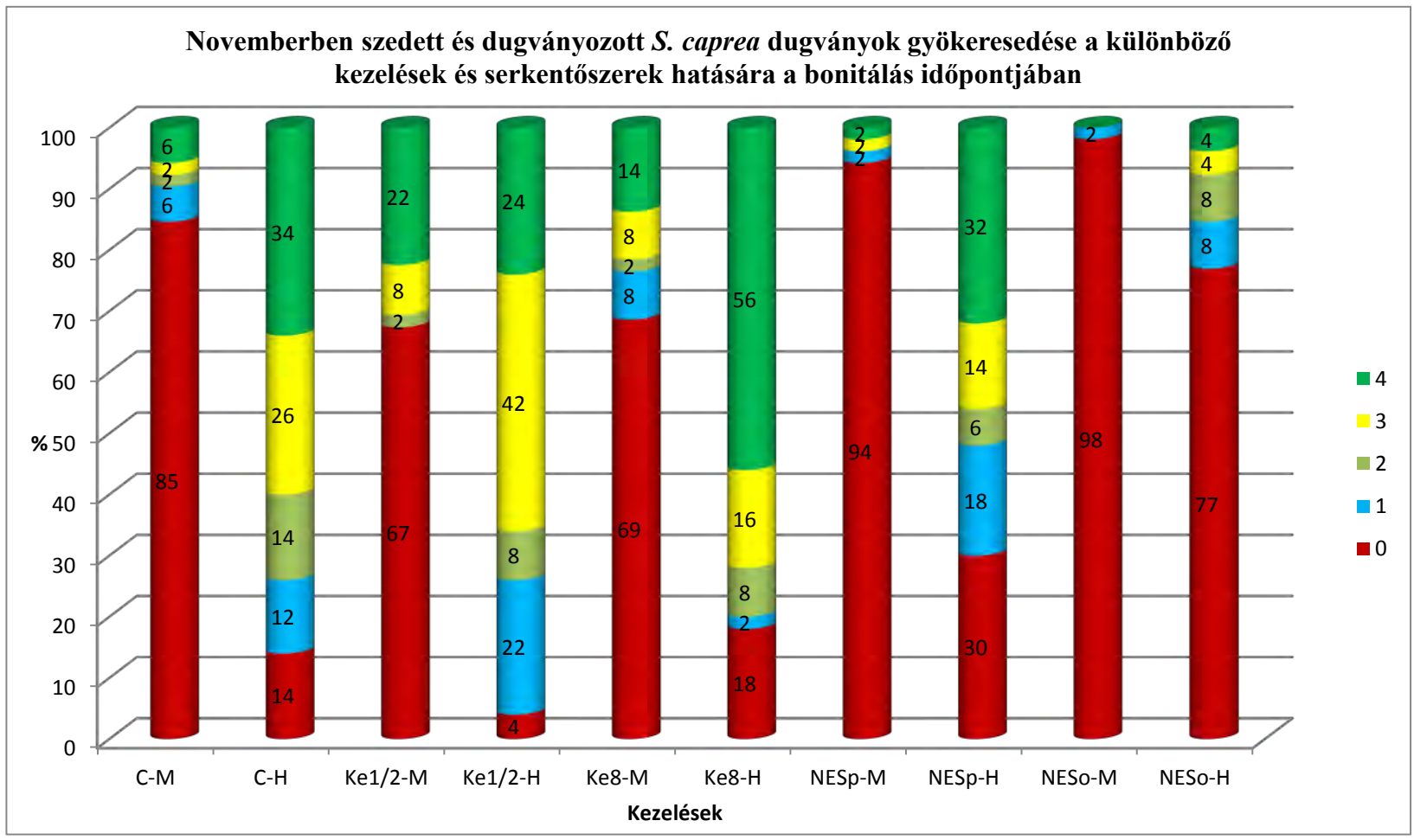

73. ábra: Novemberben szedett és dugványozott $S$. caprea dugványok gyökeresedése bonitáláskor

A decemberi dugványok lassan kezdtek gyökeresedni, hosszútávon azt bizonyítva, hogy kezelés nélkül fejlődtek legnagyobb arányban gyökerek (100\% gyökeresedés, 72\% gyökerekkel teljesen átszőtt földlabda) (74. ábra - következö oldal teteje). Második legjobb hatása ekkor is a nyolc órás Kelpak ${ }^{\circledR}$ felszívatásnak volt (100\% gyökeresedés, $67 \%$ gyökerekkel teljesen átszőtt földlabda).

Januárban is a Kelpak ${ }^{\circledR}-k a l$ végzett nyolc órás felszívatás ajánlott a gyökeresedés elősegítésére. Ekkor is jól gyökeresedett a kontroll, de három héttel a kezelés után még csak kalluszcsomók jelentek meg, míg a kezelt dugványokon ugyanekkor dugványonként 5-10 db 1020 mm-es gyökér fejlődött. A kezelés alkalmazásának jelentősége, hogy az időben meggyökeresedett dugványok becserepezése még a tavaszi munkacsúcs előtt megvalósulhat. 


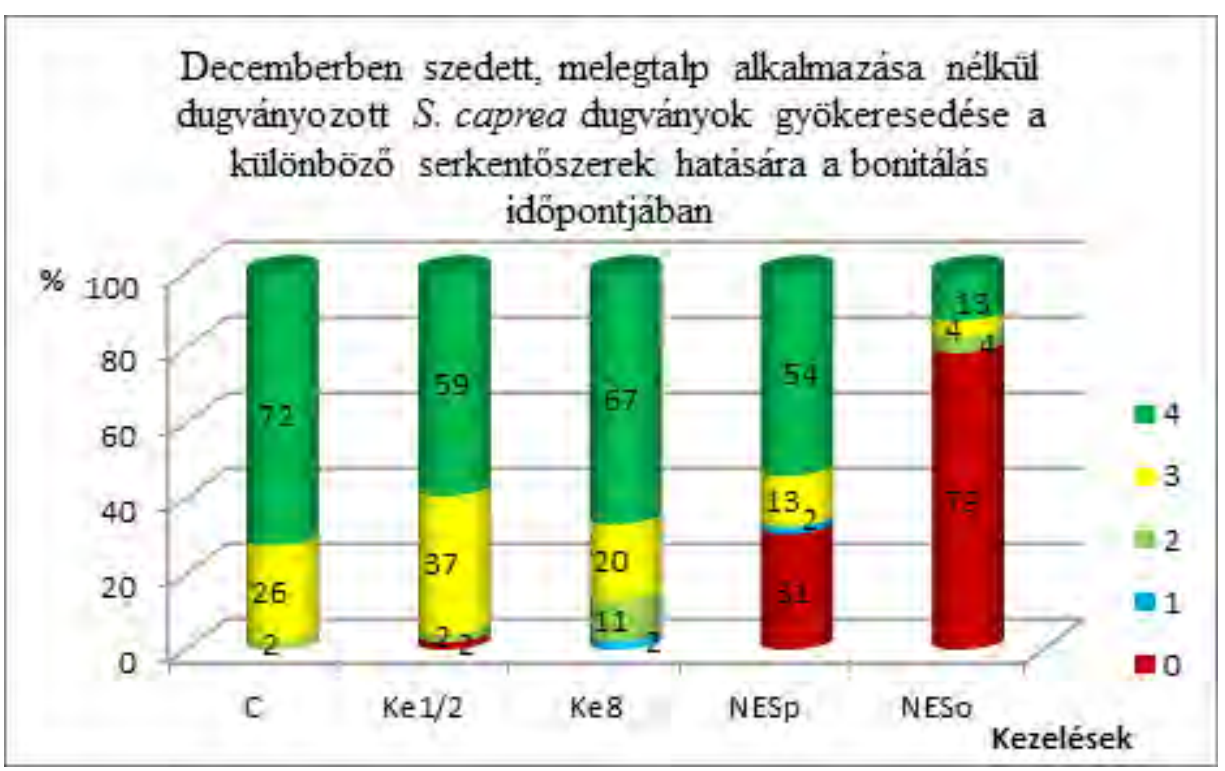

74. ábra: Decemberben dugványozott $S$. caprea gyökeresedése a bonitálás időpontjában

\subsubsection{Salix rosmarinifolia R03 klón gyökeresedése}

A S. rosmarinifolia RO3 klón dugványai a kezelések mellett is viszonylag gyengén gyökeresedtek, a serkentöszerrel elért legjobb eredmény 53\%-os gyökeresedés volt (6\%o-es NES por, decemberi dugványozás) (75. ábra). Novemberben is a 6\%-es NES porral végzett kezelés eredményezte a legtöbb (22\%) gyökeres dugványt. A késő öszi vagy tél eleji dugványok gyökereztetéséhez tehát a $6 \%$-es naftil-ecetsavval por formájában végzett kezelés javasolt. Januárban ugyanakkor már ez a kezelés kevésbé bizonyult eredményesnek, legjobban a Kelpak ${ }^{\circledR}$-kal fél órán keresztül felszívatott dugványok gyökeresedtek (38\%). A dugványok gyökereztetése során kerülendő a melegtalp alkalmazása, a gyökeresedés folyamatát nem segíti elő.

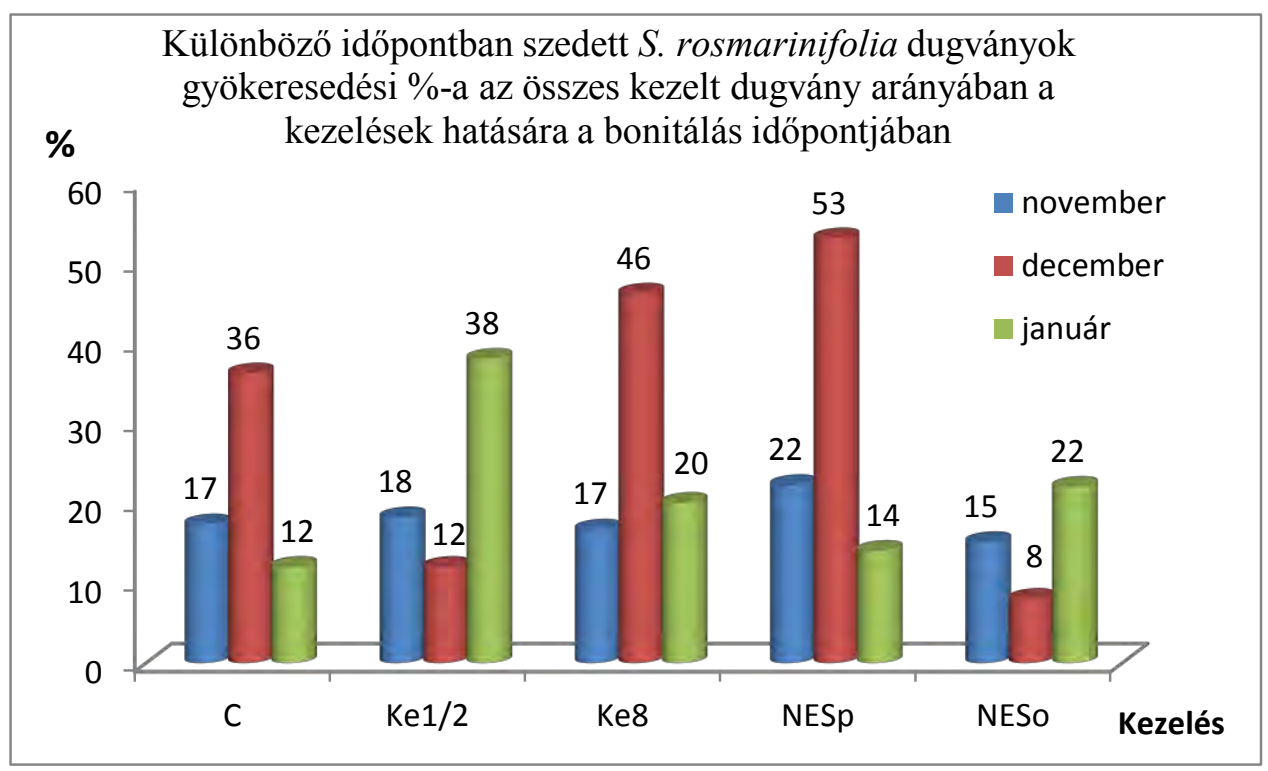

75. ábra: $S$. rosmarinifolia dugványok gyökeresedése novemberben, decemberben, és januárban végzett gyökereztetési kísérletekben a különböző kezelések hatására 
A bonitálási sorban az utolsó, „,X”-szel jelölt kategória, a dugványról levált meggyökeresedett hajtás a Kelpak ${ }^{\circledR}-k$ al kezelt dugványokra volt jellemző. Megfigyelhető volt tehát a Kelpak ${ }^{\circledR}$ hajtásfejlődést elősegítő hatása, mely így közvetetten segítette a gyökeresedést. Ezeknél a dugványoknál ugyanis az új hajtások alsó, etiolált szárrészéből fejlődtek gyökerek.

\subsection{Salix fajok károsítói és más minőségrontó tényezői}

A szakirodalomban említett kórokozók megjelenése az általam szaporított klónokon, illetve az általam vizsgált ültetvényekben nem jelentett komoly problémát. Ezért, hacsak nem jelentkezik különösen súlyos fertőzés, például szélsőségesen csapadékos időjárás esetén, az ültetvények gombaölő szeres kezelését nem tartom indokoltnak. A rozsdagombák és a hajtáselhalást okozó tömlősgomba lehullt levelekben való áttelelésének megakadályozása céljából a vágótelepeken az ősszel lehullott lombot ajánlott a területről elszállítani, esetleg a talajba beforgatni, vagy elégetni. A törzs- és tőkorhasztó gombák értelemszerűen a törzses, tehát inkább a fatermetü füzeken fordulnak elő. Idősebb ültetvényekben számíthatunk megjelenésükre a barkás vessző termesztés céljából létesített vágótelepeken is. Soroksáron már egy négyéves $S$. caprea példány tövén megjelent egy tőkorhasztó gomba, de nem befolyásolta a barkás vesszők hozamát.

A kártevők közül a levéltetvek és a szövőlepke hernyójának tömeges megjelenése okozhat gondot, ezek ellen vegyszeres védekezés javasolt. A szakirodalomban leírtakkal szemben a nagy farontólepke hernyója az országban több helyen súlyos károkat okozott barkás vessző termesztésére létesített füz ültetvényekben, károsítása nyomán a tövek rendszerint kipusztultak. A virágpiacon elhangzott beszámolókból kiderült számomra, hogy a károsított tövek ( $S$. caprea 'Silberglanz') forrása azonos volt, valószínűsítem, hogy a szaporítóanyag fertőzött volt. Ezt az a tény is megerősíti, hogy a tojásokat a fák kérgére rakó lepkék nem sokat repülnek [JENSER et al., 1998]. Ezért az ellene való védekezés első lépése az ép, egészséges, petékkel vagy lárvákkal nem fertőzött tövek telepítése. A lárvák ellen - azok rejtett életmódja miatt - nem ismert üzemi védekezés, egyedileg a hernyójáratokba benzint, szénkéneget, vagy diklorfosz készítményeket fecskendezve, majd a nyílást oltóviasszal lezárva lehet ellenük védekezni. A farontó lepke újabb károsításának megakadályozására a rajzás menetét szexferomon-csapdával lehet megállapítani, és a törzseket megfelelő időpontban permetezni. A kikelő lárvák az inszekticiddel érintkezve elpusztulnak.

A barkás vesszők tárolása során fokozott figyelmet kell fordítani a károsítók megjelenésének megakadályozására. Megfelelően zárt tárolóba egér nem juthat be, illetve csapdázható, a kötegekkel együtt esetlegesen behurcolt károsítók, mint például hernyók ellen a virágzati rügyek fakadása előtt lemosó permetezéssel lehet védekezni. 


\subsection{Salix rosmarinifolia vesszők nyílasztása}

Nyílasztási kísérletem eredményei azt bizonyítják, hogy a gibberellinsav képes a mélynyugalom megtörésére, illetve a virágfejlődés gyorsítására $S$. rosmarinifolia levágott barkás vesszőinek esetében. A hormon hat ezrelékes koncentrációjának alkalmazása felesleges, ennek a negyede (1,5\%o-es oldat) is elég volt a rügyfakadás gyorsításához (76. ábra). A február elején szedett vesszőkön vízben is megindult a virágzati rügyek fejlődése, de legalább két hét elteltével volt érzékelhető azok duzzadása, a virágzati tengely megnyúlása, a rügypikkelyek kezdődő leválása. Ezalatt könnyen kiszáradhattak a vesszők. Gibberellinsav adagolásával a virágzás pontosabban időzíthető. A vékony vesszőknél a magas páratartalomra különösen ügyelni kell, az apró rügyek könnyen beszáradnak. A betakarítás közben sérült héjú vékony vesszők hamar kiszáradtak, az óvatos kezelésre különösen oda kell figyelni. A rügyek harmadának, felének nyílása már olyan összképet mutat, mely piacképessé teszi a vesszőket. Csokorba kötve kifejezetten dekoratívak, a szemlélőben nem ébresztenek hiányérzetet, látszatra teljesen benyílt, barkával sürün berakódott vesszők. Érdemes a vesszőket idősebb szárrésszel megszedni és így nyílasztani, mert az eredmény mindig szebb, mintha ugyanezeket a vesszőket egyenként levágva állítanánk az oldatba. Nagy a kereslet a „,szálas” gyöngybarka iránt, a piacon sokszor ezt részesítik előnyben a virágkötők a „,bokros”, elágazódó áruval szemben. Ezért- amennyiben nyílasztással kívánjuk a vesszőket korán értékesíthetővé tenni, és szálas árut kívánunk előállítani -, a nyílasztást érdemes még bokros állapotban végezni, és csak a nyílasztást követően ajánlott levágni a vékonyabb barkás vesszőket a vastagabb ágrészekről.

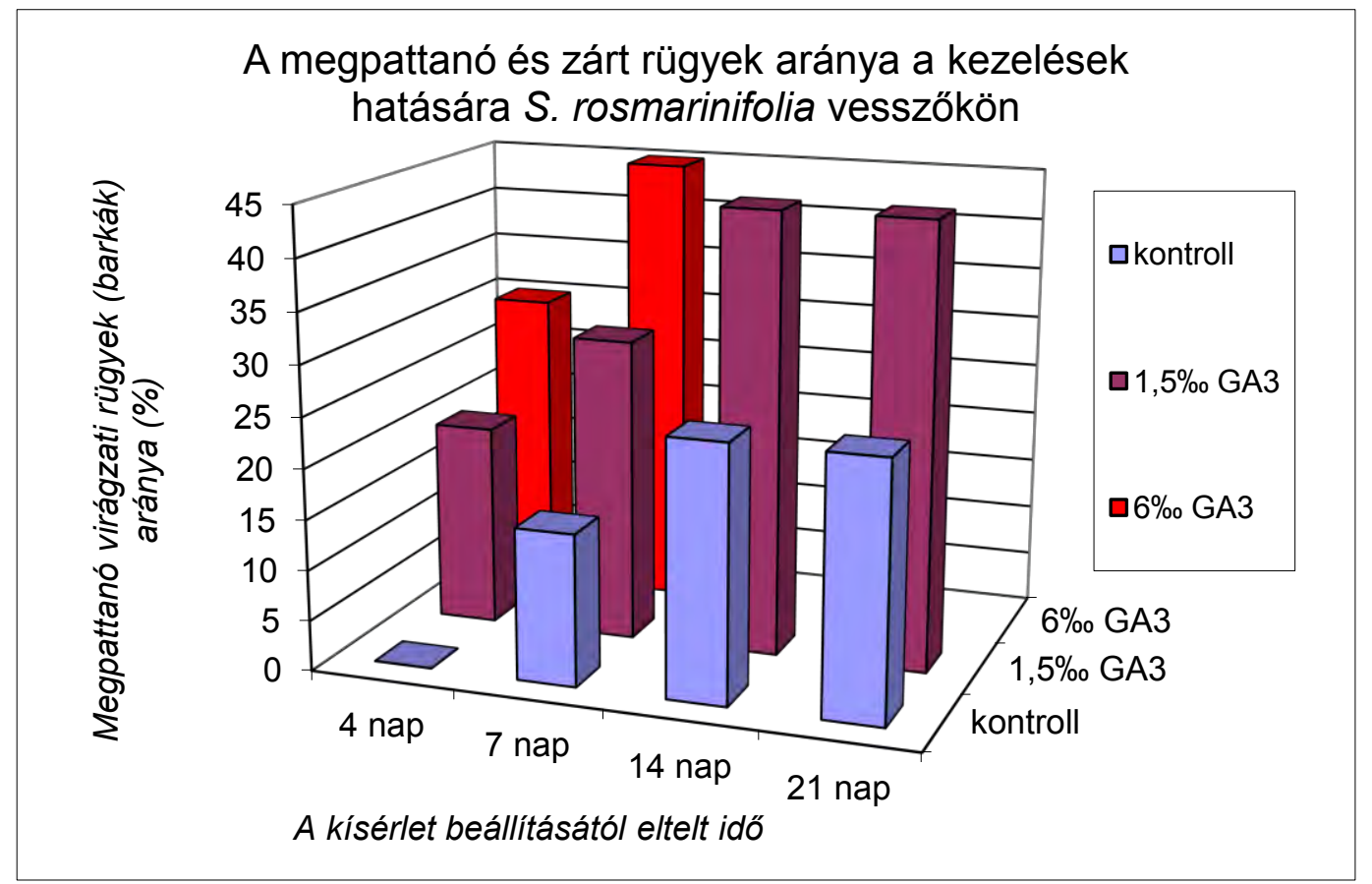

76. ábra: A megpattanó virágzati rügyek százalékos aránya a zárt rügyekhez képest $S$. rosmarinifolia vesszőkön vízben, 1,5\%o-es, és 6\%-es $\mathrm{GA}_{3}$-at tartalmazó nyílasztó oldatokban (Treerné, 2006) 


\subsection{Salix vesszők tartósítása}

A glicerines tartósítás témakörében a szakirodalom elsősorban kézikönyvek formájában áll rendelkezésre, melyek azonban nem mindig tudományosan megalapozottak, és esetenként ellentmondásosak. Ezt tapasztaltam például VAUGHAN (1998) müvében: szerinte a glicerines kezelés befejezésének idejét a glicerin növényen való kiválása jelzi. Ugyanakkor KoCH (1995) kézikönyvében részletesen leírja ezt, mint nemkívánatos jelenséget, és megmagyarázza a glicerin kiválásának okait. Egyetértek az utóbbi szerzővel. Saját tapasztalataim is azt támasztják alá, hogy a glicerines könnyezés jelensége veszélyezteti az áru eladhatóságát. Ezért a megfelelö körülmények megteremtésére különösen oda kell figyelni. Szellőztetéssel és a felszívató konténerek kellő távolságban történő elhelyezésével elkerülhető a relatív páratartalom túlzott megnövekedése a kezelés során.

A tartósító kezelések kiértékelése bizonyította, hogy hosszabb távon (három hónapon túl) a glicerines felszívatással őrizhető meg a rugalmasság, megvalósul a vesszők kellő mértékű tartósítása. Rövidtávon (két hétig) a hütőben tárolás kielégítő eredménnyel járhat $S$. caprea esetén. Korai Húsvét, illetve az ünnepet megelőző hosszantartó hideg idő esetén előfordulhat, hogy a frissen szedett vesszők Virágvasárnapig, illetve Húsvétig hütött tárolóban is kellő mértékben megőrzik rugalmasságukat. Az esetek többségében azonban indokolt a glicerines felszívatás. A statisztikai próbák alátámasztották, hogy a glicerinnel felszívatott vesszők a vizsgálati idő során mindvégig kellő mértékben megtartották rugalmasságukat.

A vékonyabb vesszőjü $S$. purpurea és $S$. rosmarinifolia glicerines tartósítása rövidtávon is szignifikánsan rugalmasabb vesszőket eredményezett, mint a többi kezelési mód.

A szobahőmérsékleten, szárazon tartott kontroll vesszők kiszáradtak, legjobban a $S$. purpurea barkái hullottak. Az összeszáradt, vesszőtől jobban elálló barkák könnyen letörhetők voltak manipulálás közben. Ezért a $S$. purpurea fajnál különösen oda kell figyelni a betakarítás megfelelő időzítésére. A vesszőket akkor célszerü levágni, mikor a rügypikkelyek többsége levált már a barkákról, de azok még nem nyúltak meg jelentősen, és a szárhoz simulnak. Ellenkező esetben a hosszúkás barkák könnyen letörnek.

Az F1 kezelésben részesített $S$. rosmarinifolia vesszőkön a fólia alatt megpattanó hajtásrügyek és megnyúló barkák arra utaltak, hogy a fólia alatt felszívatott, magasabb relatív páratartalomban tartott vesszők tovább élnek és hajtanak, ami nemkívánatos hatás a tartósítás szempontjából. A megnyúlt, glicerinnel telített, rendkívül könnyen lehulló barkák jelezték, hogy a fóliaburkolással kombinált glicerines felszívatás nem alkalmas a vesszők tartósítására. Ez a kísérlet beállítását követő negyedik napon nem látszott, a hatodik napon megkezdődött a felvett glicerin kiválása a barkák felületén, a szakirodalomban említett könnyezés jelensége. Mivel a fólia alatt 
megnövekedett a relatív páratartalom, a glicerin vizet kötött meg a vesszők környezetéböl, ezáltal a tartósító oldat felhígult a vesszőkben, végül kivált a növény felszínén. A felszívatás során ezért különösen ügyelni kell a megfelelő szellőztetésre.

A vesszők színének tekintetében a $S$. caprea faj bizonyult a legkevésbé tartósnak: szárazon tartott vesszöi kifakultak, a tartósított vesszők megbarnultak. Szárazon tárolva a $S$. rosmarinifolia örzi meg legjobban eredeti (a kísérletben szereplö klónnál: zöldes-sárga) színét, barkái is kevésbé hullanak. Ám a kiszáradt, látszólag dekoratív vesszők rendkívül törékenyek, ezáltal virágkötészeti felhasználásra alkalmatlanok. A glicerines oldatban a sárga vesszők hamar megbarnultak. Azt tapasztaltam, hogy a vöröses $S$. purpurea vesszöi tartották meg legjobban eredeti színüket a glicerines felszívató oldatban, ezért glicerines tartósítást a $S$. rosmarinifolia fajnak is vöröses vesszőszínű klónjaival (pl. RO3 és RO4) javasolt végezni. 


\section{6 ÖSSZEFOGLALÁS}

Az elmúlt évtizedben Európa-szerte, így hazánkban is a hagyományos (növényházi) vágott virágok mellett mind népszerübbé váltak az úgynevezett fás szárú vágott virágok (különleges vágott virágok) a dísznövények piacán. Ezek lehetnek a csokrot kitöltő, lazító elemek, vagy annak fö díszei. Megjelenésük, díszítőértékük megközelíti, esetenként felülmúlja a hagyományos vágott virágokét, termesztési költségük azonban jóval alacsonyabb, elsősorban a szabadföldön való termesztésnek köszönhetően. A Húsvétot megelőző időszakban keresett barkás füzvesszők is ebbe a csoportba tartoznak, melyek már tél végén megjelennek a tavaszt idéző virágcsokrokban és más virágkötészeti kompozíciókban.

Magyarország viszonylag gazdag füz fajokban, az egyes fajok változékonysága pedig rendkívül sokféle alakot és színt eredményez a barkás füzvesszők tekintetében. Hazánk 12 füzfajának számtalan alfaja, változata és hibridje olyan forrás, melyet érdemes alaposan feltárni és kiaknázni. A barkás füzvesszők napjainkban elsősorban gyüjtés útján kerülnek a hazai piacra, termesztésbe vonásuk azonban kertészeti, valamint természetvédelmi szempontból is indokolt.

A termesztéssel kapcsolatban hiányosak az ismereteink, barkafüzek termesztése barkás vessző előállításának céljából még nem gyakorlat hazánkban. Különösen a többitől teljesen eltérő habitusú, alacsony $S$. rosmarinifolia termesztése vet fel kérdéseket. A füzek köztudottan jól gyökeresednek, ugyanakkor a legszebb barkájú porzós klónok gyökeresedése rossz, illetve meglehetősen ellentmondásos a szakirodalom ezzel kapcsolatban.

A Húsvét úgynevezett mozgó ünnep, évenként változó időpontjából következően a szabadban fejlődő barkás vesszők gyakran már elnyílnak a kereslet csúcsának idejében, a $S$. rosmarinifolia virágzati rügyei pedig gyakran még nincsenek kellően fejlett állapotban.

Munkám célja a hazai barkafüzekben rejlő gazdagság bemutatása, barkás vessző termesztésére alkalmas dekoratív klónok szelekciója; a termesztésbe vonáshoz hasznos adatok szolgáltatása; a termesztés során megjelenő károsítók és hatásaik megismerése; a megfelelő gyökereztetési, nyílasztási, és tartósítási módszer kidolgozása volt.

A virágpiacon történő felméréssel sikerült átfogó képet alkotnom a barkás vesszők hazai keresletéröl és kínálatáról. A szakirodalomban barkafüzként nem említett $S$. purpurea fajt is nagy mennyiségben értékesítik, a $S$. rosmarinifolia kínálata pedig gyakorlatilag nem tudja kielégíteni a keresleti igényt, ennek az ígéretes fajnak a termesztése minden szempontból indokolt.

Munkám eredményeként egy különleges megjelenésű $S$. caprea klónt, két különböző veszszőszínű S. purpurea klónt, továbbá négy S. rosmarinifolia klónt sikerült szelektálnom. Ezeken részletes fenológiai és morfológiai megfigyeléseket és vizsgálatokat végeztem, a termesztésbe vonáshoz hasznos adatokat gyüjtöttem. A szelektált klónok közül 6 fajtajelölt leírása megjelent 
TóTH (2012) kézikönyvében. A $\boldsymbol{S}$. caprea klón idősebb tövei hamarabb nyíltak és nagyobb barkák fejlődtek rajtuk, mint az egy évvel később szaporított növényeken. Piacképes áru kisebb mennyiségben már az egyéves tövekröl is szedhető. Ez nagyrészt (86,5\%-ban) II. osztályú, kisebb arányban (12,5\%) I. osztályú vesszőket jelent. Extra méretü (120-150 cm hosszú) és gazdagon elágazódó, úgynevezett bokros vesszőket a második évtől hoz. Barkás vessző termesztéshez a megfelelő tő- és sortávolság 1 x 2,5 m. A két $\boldsymbol{S}$. purpurea klón közül a PU2 klón gyorsabban és intenzívebben gyökeresedett, mindkét klón a dugványozást követő első évben már piacképes árut adott. Évenkénti visszavágásuk feltétlenül szükséges a megfelelő minőségű vesszők fejlődése, valamint a növény kezelhetősége végett. Az ikersoros telepítés eredményeként a növénymagasság átlagosan $20 \mathrm{~cm}$-rel magasabb lett, mint a szimpla sorokban telepített növények esetében. Mivel a növények egymást árnyékoló hatásából adódóan a túlságosan hosszú vesszőknek csak a felső részén fejlődtek virágzati rügyek, a telepítés mindenképpen szimpla sorokban; 2,5 m-es sortávolságra javasolt. A $\boldsymbol{S}$. rosmarinifolia klónok végleges méretüket a dugványozást követő harmadik (RO1 és RO2), illetve negyedik (RO3 és RO4) évben érték el, megfelelő minőségű és mennyiségü áru a legalább két, a RO3 és RO4 klónok esetében hároméves tövekről szedhető. A megfelelő telepítési távolság $40 \mathrm{~cm}$ x $100 \mathrm{~cm}$ (RO1, RO2, RO4) illetve $40 \mathrm{~cm}$ x $150 \mathrm{~cm}$ (RO3). A legtöbb barkás vessző a 4-8 éves tövekről szedhető, az idősebb növények elöregednek, ezért célszerü a gyöngybarkát legalább két különböző területen négy év különbséggel telepíteni, és nyolc-tíz évig meghagyni.

A gyökereztetési kísérletek alapján megállapítottam, hogy a különlegesen dekoratív barkájú, de nehezen gyökeresedő $S$. caprea CA1 klón és a S. rosmarinifolia RO3 klón gyökeresedése javítható az alábbiakban ismertetett kezelésekkel.

A S. caprea dugványokon serkentőszer nélkül is megkezdődött a kalluszcsomók képződése, melegtalpon kielégítő gyökérképződést tapasztaltam, legjobban a januárban szedett dugványok gyökeresedtek. A 6\%o-es NES-sel oldat formájában végzett kezelés nem ajánlható a gyökerezés serkentésére, mert a kezdeti rendkívül intenzív kalluszképződést követően - különösen melegtalpon - a dugványok jelentős hányada elpusztult. A 6\%o NES-sel por formában végzett kezelés melegtalp nélkül javasolt, így a novemberi dugványokon már egy hét után kalluszcsomók jelentek meg, és nyolc hét alatt fejlődött legalább $5 \mathrm{db}$, átlagosan $25 \mathrm{~mm}$ hosszú gyökér dugványonként. A januárban szedett dugványokon a kezelés intenzív kalluszképződést és gyökérkezdemények megjelenését eredményezte már két héttel a dugványozást követően. A serkentőszerek közül legjobb hatása a Kelpak ${ }^{\circledR}$ biostimulátornak volt a $S$. caprea dugványok gyökeresedésére. A fél órás felszívatással kezelt dugványok melegtalp nélkül jobban gyökeresedtek. Melegtalpon a novemberben és decemberben szedett dugványok 33-34\%-a elpusztult. A 8 órás felszívatás hatása melegtalppal kombinálva érvényesült jobban, a decemberben és januárban 
szedett dugványok 54-56\%-án dugványonként legalább 5 db, átlagosan 5 mm-es gyökér fejlödött a kezelést követően kettő (január), illetve három (december) héttel.

A S. rosmarinifolia dugványok gyökereztetése során a melegtalp alkalmazása kerülendö, a gyökerezés folyamatát nem segítette elő, a legtöbb esetben a dugványok pusztulását okozta. Melegtalp alkalmazása nélkül a novemberben és decemberben szedett dugványok esetében a 6\%o NES-sel por formában végzett kezelés serkentette legjobban a gyökeresedést. Novemberben nyolc hét elteltével jelentek meg a 10 mm-es gyökerek a dugványokon, a decemberi gyökeresedés lassabban indult, és pozitív hatása a kezelést követően 13 héttel volt egyértelmü, mikor a dugványok 27\%-a gyökerekkel többé-kevésbé átszőtte a sejttálca földlabdáját (22\%-nál 10 mmnél rövidebb gyökerek és kalluszcsomók képződtek). Második legjobb hatása a S. rosmarinifolia novemberi és decemberi dugványainak gyökeresedésére a Kelpak ${ }^{\circledR}$ biostimulátorral 8 órán keresztül végzett felszívatásnak volt. A januárban szedett dugványok a biostimulátorral fél órán keresztül végzett felszívatás hatására gyökeresedtek legjobban: 52 nap alatt a dugványok 26\%-a gyökerekkel többé-kevésbé átszőtte a földlabdát, 14\%-on gyökerek és kalluszcsomók képződtek.

Barkás vessző termesztésére szelektált Salix klónjaimon, továbbá az általam meglátogatott ültetvényekben és élőhelyeken megfigyeltem és meghatároztam a következő károsítókat. Kórokozók: Erysiphe adunca, Drepanopeziza sphaeroidea, Melampsora sp., Phellinus igniarius. Kártevők: Chaitophorus salijaponicus, Chaitophorus salicti, Pterocomma salicis, Arctornis lnigrum, Pontania vesicator, Cossus cossus, Xanthia togata, Rodentia, Stylommatophora. A kórokozók megjelenése az ültetvényekben nem okozott problémát, védekezés csak súlyos fertőzésükkor, például szélsőségesen csapadékos időjárás esetén indokolt ellenük. A kártevők közül a levéltetü fajok és a szövőlepke (Arctornis l-nigrum) károsította esetenként olymértékben a lombot, illetve hajtásokat, hogy annak negatív hatása volt a vesszők fejlődésére és beérésére, ezáltal a következő évi barkás áru minőségére. A nagy farontó lepke (Cossus cossus) hernyói a füz tövek teljes pusztulását okozták több hazai termesztő ültetvényében, a levágott vesszők értékesítés előtti tárolása során pedig a Xanthia togata bagolylepke hernyói okozhatnak súlyos károkat.

A többi füz fajhoz képest legalább négy héttel később nyíló $S$. rosmarinifolia nyílasztása során a rügyek mélynyugalmát $\mathrm{GA}_{3}$ alkalmazásával sikeresen lehet megtörni, így a virágzás is pontosan időzíthető. A vesszőkön a virágzati rügyek 30-50\%-ának fakadása már piacképes árut eredményez. A rügypikkelyek rendszerint fent maradnak a vesszőkön, de ez a többi füz faj barkás vesszőjével szemben nem csökkenti a gyöngybarka díszítőértékét. A hormon 1,5\%o-es koncentrációjának alkalmazásával a kísérlet beállítását követően két héttel a generatív rügyek 50\%-a fejlődésnek indult. A négyszeres, azaz 6\%o-es koncentrációval ugyanezt a hatást egy héttel korábban sikerült elérnem. A gyöngybarka nyílasztásához tehát megfelelő az alacsonyabb koncentráció is, de a kívánt értékesítési időszak előtt időben el kell kezdeni a kezelést. Az egy évesnél 
idősebb alsó szárrésszel megszedett, és a nyílasztó oldatba így állított vesszőkön a nyílasztott barkák mérete akár 50\%-kal nagyobb lett, mint a vékony, egyéves, egyszálas vesszőkön, tehát nyílasztás céljára javasolt a vesszőket többéves alsó résszel megszedni.

A barkás vessző tartósítási kísérletek eredményeinek értékelésére nem létezett megfelelő, objektív mérési módszer. Ezért kidolgoztam a vesszők rugalmasságának mérésére szolgáló módszert, és elkészítettem, illetve beszereztem a mérés kivitelezéséhez szükséges eszközöket. A több képletből általam levezetett és alkalmazott következő képlettel határoztam meg a vesszők úgynevezett effektív Young-modulusát, mellyel a különböző kezelések által elért rugalmasságot sikerült pontosan számszerüsítenem: $E=l^{3} F\left[12 s \pi R^{4}\right]^{-1}$, ahol $l$ : a vessző két rögzítési (alátámasztási) pontjának távolsága ( $S$. caprea esetén $l=0,4 \mathrm{~m}$; $S$. purpurea és $S$. rosmarinifolia esetén $l=$ $0,25 \mathrm{~m}) ; F$ : a két alátámasztási pont között félúton ható, vesszőre gyakorolt, $40 \mathrm{~mm}$-es hajlításhoz szükséges erő (grammból Newtonba átszámítva: /1000*9,81), kézi erőmérővel, 3x ismétléssel mérve; $s$ : a lehajlás mértéke, azaz a támaszok magassága $=0,04 \mathrm{~m} ; R$ : a vesszők keresztmetszetének sugara, a vesszők két pontján mért átmérők átlagából számolva.

A tartósítási kísérletek során $S$. caprea esetében rövidtávon (2 héten belül) a hütőben való tárolás a glicerinnel tartósított vesszőkhöz hasonlóan rugalmas vesszőket eredményezett, ezért amennyiben csak ilyen rövid idő telik el a betakarítás és felhasználás időpontja között - ez a módszer is kielégítő lehet. A vékonyabb vesszőjü $S$. purpurea és $S$. rosmarinifolia glicerines tartósítása már rövidtávon is szignifikánsan rugalmasabb vesszőket eredményezett, mint a többi kezelési mód. A glicerinnel való kezelés mindhárom faj esetében hatékonynak bizonyult a rugalmasság megőrzésében. A S. caprea faj esetében 33\%v/v-os glicerinnel történő egy hetes felszívatás volt eredményes, a $S$. purpurea faj vesszőit $50 \% \mathrm{v} / \mathrm{v}-\mathrm{os}$ glicerines oldattal egy hétig felszívatva sikerült tartósítanom, a S. rosmarinifolia vesszői 50\%v/v-os, két hetes felszívatást követően maradtak a leginkább rugalmasak, a kísérlet beállítását követő 16. héten mért eredmények alapján is. A szobahőmérsékleten, szárazon tartott kontroll vesszők kiszáradtak, legjobban a $S$. purpurea barkái hullottak. A S. rosmarinifolia kontroll vesszői látszólag dekoratívak maradtak, a barkák kevésbé hullottak róluk, de a vesszők kiszáradtak és törékenyek lettek, ezáltal virágkötészeti felhasználásra alkalmatlanná váltak. A három faj vesszői közül ez utóbbi színe fakult ki legkevésbé, a szárazon tartott kontroll vesszők színesek (zöldessárgák) maradtak. A vesszők színének tekintetében a $S$. caprea faj bizonyult a legkevésbé tartósnak: szárazon tartott vesszői kifakultak, a tartósított vesszők megbarnultak. A vöröses $S$. purpurea vesszői tartották meg legjobban eredeti színüket a glicerines felszívató oldatban.

Az elmúlt tíz évben végzett munkám bizonyítja, hogy hazánk flórájából több ígéretes Salix taxon szelektálható barkás vessző termesztésére. Az általam kidolgozott módszerekkel a szelektált klónok sikeresen szaporíthatóak, illetve szükség szerint nyílaszthatóak vagy tartósíthatóak. 


\section{Summary}

In the marketing of ornamental plants, the so called woody cuts are becoming more and more popular among traditional (greenhouse) cut flowers throughout Europe, and also in Hungary in the last decade. These woody cuts serve as fillers or even as main decorative elements in a bouquet. Their appearance, as well as their decorative value, is very desirable. Sometimes they even exceed that of traditional cut flowers. Cultivation costs are much lower due to open ground production. The cut stems and branches of willow species with catkins (appearing before the leaves) are a type of woody cuts. Their main demand period is before Easter, but they often start to show up in February in bouquets and in floral spring compositions.

There is a relatively big number of willow species in Hungary. There is also considerable cross pollination in nature resulting in many forms and transition forms. This variability in the 12 Salix species, their subspecies, varieties and hybrids should be discovered and exploited. Today, cut willow twigs with catkins mainly come to the Hungarian market from gathering. It would be good both from the aspect of horticultural production and the protection of nature as well to take them into formal production.

Our knowledge is incomplete about production, because the cultivation of willow species to produce woody cuts decorated with catkins is not yet practiced in Hungary. This is especially true for the production of the prostrate $S$. rosmarinifolia, which has a totally different habit than other Salix species. As it is commonly known, willows root easily. At the same time, the most decorative male clones root poorly. The relevant literature is also quite contradictory.

Easter is a so-called moving holiday: its date changes every year. Thus the catkins developing in the fields often are already in full bloom and unsaleable. The later forming catkins of $S$. rosmarinifolia are not yet developed enough by the time of the peak demand.

The aim of my work is to present the richness resulting from Hungarian willows' variability; to select decorative clones capable for woody cuts' production; to provide useful data and information for taking (them) into production; to discover pathogens \& pests and their effects on woody cut production; and to work out the proper method of vegetative propagation (rooting), forcing, and preservation of the cut twigs.

Surveying the largest flower wholesale market, I sized up the supply and demand of the pussy willow cut twigs in Hungary. The species $S$. purpurea is not a pussy willow according to relevant horticultural works, but it is also offered for sale in a considerable amount. The supply of $S$. rosmarinifolia cut twigs does not satisfy demand. Therefore, its cultivation is indeed reasonable. 
A fancy looking $S$. caprea clone, two $S$. purpurea clones with different stem colors, and four $S$. rosmarinifolia clones were selected as a result of my work. Useful data and information were collected for taking them into production by phenological and morphological observations of the clones in details. Description of six of the selected clones was published in the reference book of TóTH (2012). Older specimens of the $\boldsymbol{S}$. caprea clone bloomed earlier and developed larger catkins than stools propagated one year later. The one-year-old stools yielded $86 \% 2^{\text {nd }}$ class and $14 \% 3^{\text {rd }}$ class cut twigs. Extra size (120-150 cm long) and branching twigs grow on at least two years old plants. To produce pussy willow cut stems the proper planting distance is $1 \mathrm{~m}$ x 2,5 m. PU2 clone of the two $S$. purpurea clones rooted more rapidly and intensively than the other clone, and both of them produced marketable cut twigs the first year after propagation. In order to produce good quality twigs and to keep the plants at a reasonable size, it is necessary to cut them back every year. Plant height grew $20 \mathrm{~cm}$ in average as a result of twin row spacing according to stools planted in simple rows. Since too long stems developed catkins only on their tops due to shade caused by close planting, it is recommended to space in simple rows with 2,5 $m$ distance. $S$. rosmarinifolia clones reached their final size by the $3^{\text {rd }}(\mathrm{RO} 1 \& \mathrm{RO} 2)$ or $4^{\text {th }}(\mathrm{RO} 3$ \& RO4) year after propagation. Woody cuts in sufficient amount and quality can be harvested from at least two (RO1 \& RO2) or three (RO3 \& RO4) years old plants. Proper planting space is $40 \mathrm{~cm}$ x $100 \mathrm{~cm}$ (RO1, RO2, RO4) or $40 \mathrm{~cm}$ x $150 \mathrm{~cm}$ (RO3). The largest amount of pussy willow catkins can be harvested from 4-8 years old stools. Older plants age and stunt so it is practical to site the plants on at least two different territories with four years difference and sustain the stools for eight to ten years.

Based on my experiments on rooting the otherwise hard rooting CA1 \& RO3 clones of $S$. caprea and S. rosmarinifolia respectively, which have especially decorative catkins, can be improved by applying the following treatments.

Formation of callus started on $S$. caprea cuttings without applying bioregulator or hormone treatment; sufficient root formation occurred on heated bins; and most intensive rooting was performed by cuttings propagated in January. Treatment with NAA (naphthyl-acetic-acid) in 50\% ethanol solution is not recommended to improve rooting, because following the initial extremely intensive callus formation - especially on heated bins - a significant proportion of the cuttings died. Treatment with NAA in the form of talcum powder is recommended without bottom heat. As a result of this treatment, callus was formed on cuttings propagated in November after one week. It took eight weeks to develop at least five, $25 \mathrm{~mm}$ long roots per cuttings. The treatment resulted in intensive callus formation and initiation of adventitious roots on the cuttings propagated in January in two weeks. Of all rooting compounds involved in the experiment, the bioregulator called Kelpak ${ }^{\circledR}$ had the best effect on the rooting of $S$. caprea cuttings. Cuttings treated 
with $\mathrm{Kelpak}^{\circledR}$ for 30 minutes rooted better without bottom heat. 33-34\% of the cuttings propagated in November and December perished on heated bins. The effect of the 8 hour long Kelpak ${ }^{\circledR}$ treatment was better expressed in combination with bottom heat. At least five, $5 \mathrm{~mm}$ long roots/cuttings formed on 54-56\% of the cuttings propagated in December and January in three or two weeks, respectively.

Using bottom heat is not recommended during the propagation of $S$. rosmarinifolia cuttings. It did not improve root formation. In most cases, cuttings died due to this treatment. Without bottom heat, root formation was best improved by 6\% NAA powder treatment in case of cuttings propagated in November and December. It took eight weeks in November to form 10 $\mathrm{mm}$ long roots. Root formation took longer in case of propagating in December. Positive effect of the treatment showed up 13 weeks later when $27 \%$ of the cuttings rooted well in the rooting medium (another $22 \%$ formed callus \& roots shorter than $10 \mathrm{~mm}$ ). Eight hour long treatment with the bioregulator Kelpak ${ }^{\circledR}$ had the second best effect on the rooting of S. rosmarinifolia cuttings propagated in November and December. Cuttings propagated in January showed best root formation following 30 minutes of Kelpak $^{\circledR}$ treatment: $26 \%$ of the cuttings rooted well in the rooting medium, $14 \%$ formed callus and roots in 52 days.

On the clones selected for woody cuts' production and in their plantings and habitats, I observed and identified the following pathogens \& pests. Pathogens: Erysiphe adunca, Drepanopeziza sphaeroidea, Melampsora sp., Phellinus igniarius. Pests: Chaitophorus salijaponicus, Chaitophorus salicti, Pterocomma salicis, Arctornis l-nigrum, Pontania vesicator, Cossus cossus, Xanthia togata, Rodentia, Stylommatophora. The existence of the diseases did not cause a problem. Plant protection is necessary only in case of severe infections; during times of extremely high amount of rainfall, for instance. Aphids and caterpillars of black v moths (Arctornis lnigrum) harmed the leaves and shoots to such an extent that it had a negative effect on the growth and ripening of the shoots and twigs and therefore on the quality of the woody cuts produced for sale next spring. Caterpillars of goat moth (Cossus cossus) totally ruined some willow stools in some plantings in Hungary. Caterpillars of pink-barred sallow (Xanthia togata) can cause serious damage during storage of the cut stems.

Dormancy of the buds of S. rosmarinifolia blooming at least four weeks later than other examined willow species could be broken successfully by applying $\mathrm{GA}_{3}$ in the forcing solution, so that the desired state of catkins can be precisely timed. $30-50 \%$ bud break of the generative buds results in products ready to sell. Bud scales normally stay on the twigs by the catkins, but in contrast with other willow twigs - it does not reduce the decorative value of the twigs called pearl-catkins in Hungary. Two weeks after starting the trials, $50 \%$ of the generative buds started to develop by using $1,5 \%$ concentration of the hormone. The four times higher, $6 \%$ o hormone 
concentration had the same effect a week earlier. So the lower concentration proved to be sufficient for forcing $S$. rosmarinifolia twigs. Treatment should take place, however, in adequate time before the desired sales' period. Twigs cut with a stem older than a year old produced even $50 \%$ larger catkins in the forcing solution so it is recommended to cut the twigs with an older section of the stem for forcing.

To evaluate the results of the preservation experiment, no proper method existed. Therefore a new method of evaluating the results was worked out by determining the elastic modulus of the twigs under different treatments. Using several different formulas the effective Youngmodulus of the twigs was calculated, thus the elasticity resulting from the different treatments became numerical. Young-modulus: $E=l^{3} F\left[12 s \pi R^{4}\right]^{-1}$, where $l$ : is the interval between the twig's two points of support (in case of Salix caprea $l=0,4 \mathrm{~m}$; in case of $S$. purpurea $\& S$. rosmarinifolia $l=0,25 \mathrm{~m}) ; F$ : the force needed to bend the twig $40 \mathrm{~mm}$ down in the middle of the above mentioned interval, measured with a manual dynamometer (each twig three times); $s$ : the scale of stoop; $R$ : the radius of the twigs' cross section calculated from the average diameter of the twigs measured at the two points of support with a digital caliper. A special stand was also designed and created to help with the measurements and the determination of the elastic modulus.

Cold storage had similar effects to glycol (glycerin) preservation on the suppleness of $S$. caprea twigs in the short term (within two weeks). Therefore cold treatment can be sufficient only when there is a short time period between the time of harvest and the usage. Thinner twigs of $S$. purpurea \& S. rosmarinifolia proved to be significantly suppler due to glycol preservation even in a short time period. Treatment with glycerin proved to be efficient in the preservation of all three species. Best results were achieved by using 33 percent by volume glycerin solution for one week in the case of $S$. caprea, 50 percent by volume glycerin solution for one week long treatment in case the of $S$. purpurea, and 50 percent by volume solution for two weeks long uptake in the case of $S$. rosmarinifolia twigs. Results showed that the twigs' elasticity was preserved even 16 weeks after the experiment set-up. Control twigs kept in room temperature dried out and the most catkins fell from the $S$. purpurea twigs. Control twigs of $S$. rosmarinifolia kept their decorative appearance and lost fewer catkins, but the stems dried out and become so brittle that they could not be used in any floral arrangements. Their color faded the least and the dry control twigs kept their greenish yellow stem color. S. caprea proved to be the least stable in point of stem color: the dry control twigs faded and the preserved twigs turned brown. The reddish S. purpurea twigs kept their original color best in the systemic preservation solution. 
The research done in the last ten years proves that many promising taxa could be selected from our flora for producing woody cuts with decorative catkins and stem color. The selected clones can be successfully propagated, forced or preserved as needed by the described methods. 


\section{IRODALOMJEGYZÉK}

1. A Magyar Állami Természetvédelem hivatalos honlapja (2013): Védett fajok. http://www.termeszetvedelem.hu/?pg=vf\&mode=search\&magyarnev=\&latinnev=Salix \&t ag_kat_magy $=\mathrm{Z} \% \mathrm{C} 3 \% \mathrm{~A} 1 \mathrm{rvaterm} \% \mathrm{C} 5 \% 91 \mathrm{k}+\% 28 \mathrm{t} \% \mathrm{C} 3 \% \mathrm{~B} 6 \mathrm{rzs} \% 29 \& \mathrm{tag}$ kat_lat $=$ Angio spermatophyta+\%28phylum\%29\&szuk_kat_magy=F\%C5\%B1zf\%C3\%A91\%C3\%A9k+ $\% 28 \mathrm{csal} \% \mathrm{C} 3 \% \mathrm{~A} 1 \mathrm{~d} \% 29 \&$ szuk_kat_lat $=\&$ ertek $=\&$ ev $=\&$ fokvedev $=\&$ melleklet $=\&$ iranyelv $=0 \&$ egyezmen $y=0 \&$ orderby $=$ latinnev $\&$ direction $=$ asc \&headers $=50.2013 .11 .25 .10: 30$

2. ABONYi N. (1998): Növekedés-szabályozók hatása egyes cserepes virágos dísznövények díszítő értékére. Diplomamunka. Budapesti Corvinus Egyetem, Kertészettudományi Kar, Dísznövénytermesztési és Dendrológiai Tanszék. p. 22-26.

3. Algeier W. (2010): Vágócserjék Móron. Kertészet és Szölészet. 59. (13.) p. 6-8.

4. ANIL K. et al (2013): Flora of India. Salix aegyptiaca L. https://sites.google.com/site/efloraofindia/species/m---z/s/salicaceae/salix/salixaegyptiaca. 2013.10.30. 12:05

5. APG (Angiosperm Phylogeny Group) (2003): An update of the Angiosperm Phylogeny Group classification for the orders and families of flowering plants: APG II. Botanical Journal of the Linnean Society 141 p. 399-436. folyóirat DOI-ja?

http://onlinelibrary.wiley.com/doi/10.1046/j.1095-8339.2003.t01-1-00158.x/full. 2011.03.31. 18:58

http://dx.doi.org/10.1046/j.1095-8339.2003.t01-1-00158.x

6. APG (Angiosperm Phylogeny Group) (2009). An update of the Angiosperm Phylogeny Group classification for the orders and families of flowering plants: APG III. Botanical Journal of the Linnean Society 161 (2) p. 105-121.

http://onlinelibrary.wiley.com/doi/10.1111/j.1095-8339.2009.00996.x/full. 2011.03.31. $18: 58$ http://dx.doi.org/10.1111/j.1095-8339.2009.00996.x

7. APG (The Angiosperm Phylogeny Group) (1998): An ordinal classification for the families of flowering plants. Annals of the Missouri Botanical Garden 85. p. 531-553. http://www.jstor.org/discover/10.2307/2992015?uid=3738216\&uid=2\&uid=4\&sid=2110 3093472617. 2011.03.31. 17:00 http://dx.doi.org/10.2307/2992015

8. ARIAS, O., CRABBÉ, J. (1975): Les gradients morphogénétiques du rameau d'un an des végétaux ligneux, en repos apparent. Données complémentaires fournies par l'étude de Prunus avium L. Physiologie Végétale 13. p. 69-81. 
9. ARmitage, A. M. (1993): Specialty Cut Flowers. The production of annuals, perennials, bulbs and woody plants for fresh and dried cut flowers. Varsity / Timber Press. Portland, Oregon. p. 11-26, 31-34, 338-340.

http://dx.doi.org/10.1016/B978-0-12-437651-9.50012-9

10. BAILEY, L. H. (1958): The standard cyclopedia of horticulture. 17th Printing. Vol. III: New York. The Macmillan Company. p. 3050-3055.

11. BALÁZs K., MÉSZÁros Z. (1998): Lepkék - Lepidoptera. (In: JENSER et al.: A szántóföldi és kertészeti növények kártevői.) Mezőgazda Kiadó. Budapest. p. 301-303.

12. BARTHA D. (1997): Fa- és cserjehatározó. Mezőgazda Kiadó. Budapest. p. 44-46, 62, 126-129, 156, 189-190, 197.

13. BARTHA D. (1999): Magyarország fa- és cserjefajai. Mezőgazda Kiadó. Budapest. p. 214234.

14. BARThA D. (2007): Dendrológia 4. előadás. Salicaceae család. PowerPoint prezentáció. 1-62 dia

15. BARTHA D. (2008): Az év fája. A törékeny füz (Salix fragilis) botanikai jellemzése. Erdészeti Lapok 143 (1) p. 10-11.

16. BASler, D.; KORNER, C. (2012): Photoperiod sensitivity of bud burst in 14 temperate forest tree species. Agricultural and Forest Meteorology. Vol. 165. p. 73-81. http://dx.doi.org/10.1016/j.agrformet.2012.06.001

17. BeAn, W. J. (1981): Trees and Shrubs hardy in the British Isles. Vol. IV. Murray. London. p. 246-312.

18. BEAN, W. J. (1988): Trees and Shrubs hardy in the British Isles. Supplement. Murray. London. p. 484-487.

19. BIDABÉ, B. (1967): Action de la température sur l'évolution des bourgeons de pommier et comparaison des méthodes de contrôle de l'époque de floraison. Annales de Physiologie Végétale 9. p. 65-86.

20. Bloemisterij, Staalkaart (1997). 52e jaarg. 23 mei. p. 44.

21. Bloemisterij, Staalkaart (1998). 53e jaarg. 29 mei. p. 43.

22. Bloemisterij, Staalkaart (1999). 54e jaarg. 28 mei. p. 50.

23. Bloemisterij, Staalkaart (2000). 55e jaarg. 26 mei. p. 60.

24. Bloemisterij, Staalkaart (2001). 56e jaarg. 25 mei. p. 62. 
25. Bloemisterij, Staalkaart (2002). 57e jaarg. 7 juni. p. 69.

26. Bloemisterij, Staalkaart (2003). 58e jaarg. 23 mei. p. 79.

27. Bloemisterij, Staalkaart (2004). 59e jaarg. 21 mei. p. 83.

28. Bloemisterij, Staalkaart (2005). 60e jaarg. 27 mei. p. 73, 77.

29. Bloemisterij, Staalkaart (2006). 61e jaarg. 26 mei. p. 71, 75.

30. Bloemisterij, Staalkaart (2009). 64e jaarg. 22 mei. p. 92, 95.

31. Boer, B.G.W., Murray J.A.H. (2000): Control of plant growth and development through manipulation of cell-cycle genes. Curr. Opin. Biotechnol 11. p. 138-145

32. BORCHERT, R. (1991): Growth periodicity and dormancy. In: Raghavendra, A. S. (szerk.): Physiology of Trees. Jonh Wiley. New York. p. 221-245.

33. BORHIDI A. (1998): A zárvatermők fejlődéstörténeti rendszertana. Nemzeti Tankönyvkiadó. Budapest. p. 64-66., 134-135., 250-251.

34. Bose, T. K., Jana, B. K., Mukhopadhyay (1980): Effects of growth regulators on growth and flowering in Hippeastrum hybridum hort. Scientia Horticulturae 12. p. 195200.

35. BöRnER, C. (1957): Tierische Schädlinge an Nutzpflanzen. 2. Teil. Homoptera. In: Sorauer, P. (szerk.): Handbuch der Pflanzenkrankheiten. Paul Parey. Berlin und Hamburg. p.65, 90.

36. BRÜCKNER GY. (1961): Szerves kémia I-1 kötet. Tankönyvkiadó. http://hu.wikipedia.org/wiki/Zs\%C3\%ADrok 2013.04.20. 20:49.

37. Budó Á. (1972): Mechanika. Tankönyvkiadó. Budapest. p. 277-281.

38. Campbell, M. A., Suttle, J. C., Sell, T. W. (1996): Changes in cell cycle status and expression of $\mathrm{p} 34 \mathrm{cdc} 2$ kinase during potato tuber meristem dormancy. Physiologia Plantarum 98. p. 743-752.

39. CAROW, B. (1978): Frischhalten von Schnittblumen. Verlag Eugen Ulmer. Stuttgart. p. 53., 122.

40. Cell Cycle Regulation (2013) honlap. http://biogirls4life.wordpress.com/cell-cycleregulators. 2013.04.21. 11:54

41. Champagnat, P. (1983): Quelques réflexions sur la dormance des bourgeons des végétaux ligneux. Physiologie Végétale. 21: 607-618.

42. Champagnat, P. (1992): Dormance des bourgeons chez les végéteaux ligneux. In: Côme, 
D. (szerk.) Lés Végétaux et le Froid. Hermann. Paris. p. 203-262.

43. Chang, R. (1984): Chemistry. 2nd edition. Random House. New York. NY. USA. Cit. Koch, M. (1995): Preserving Flowers and Foliage with Glycols and Dyes. A Manual for the Commercial Producer. Robert Koch Industries, Inc. Bennett. CO. USA. p. 61.

44. CORR, B. E., WIDMER, R. E. (1987): Gibberellic acid increases flower number in Zantedeschia elliottiana and Z. rehmannii in response to environmental factors. HortScience 22 (4). p. 605-607.

45. Corr, B. E., Widmer, R. E. (1991): Paclobutrazol, gibberellic acid, and rhizome size effect growth and flowering of Zantedeschia. HortScience 26 (2). p. 133-135.

46. Crabbé, J., Barnola, P. (1996): A New Conceptual Approach to Bud Dormancy in Woody Plants. In: Lang, G. A. (szerk.): Plant Dormancy: Physiology, Biochemistry and Molecular Biology. CAB INTERNATIONAL. Irrigated Agriculture Research and Extension Center. Washington State University. Professor, WA. USA. p. 83-114.

47. CSAPÓ J., CSAPÓNÉ KISS Zs. (2002): Tej és tejtermékek a táplálkozásban. Mezőgazda Kiadó. http://www.tankonyvtar.hu/hu/tartalom/tkt/tej-tejtermekek/ch03s03.html. 2013. 04. 20. 10:50.

48. CSAPODY I. (1982): Védett növényeink. Gondolat. Budapest. p. 24, 325.

49. CSAPODY I., CSAPOdY V., JÁvORKA S. (1993): Erdő-mező növényei. 2. kiadás. Budapest Mezőgazda Kiadó. p. 46-47.

50. Csonka Z. A. (2003): A füzfa hajtáselhalása. Kertészet és Szölészet. 52 (48) p. 13-14.

51. DenNis, D. J., DoREen, J., OHTEKI, T. (1994): Effect of a gibberellic acid 'quick-dip' and storage on the yield and quality of blooms from hybrid Zantedeschia tubers. Scientia Horticulturae 57. p. 133-142.

52. DevitT, M.L., StAfstrom, J.P. (1995): Cell cycle regulation during growth-dormancy cycles in pea axillary buds. Plant Mol. Biol. 29. p. 255-265.

53. DIRR, M. A. (1998): Manual of Woody Landscape Plants. Fifth Edition. Stipes. Champaign, Illinois. p. 921-927.

54. DIRR, M. A. (1999): Dirr's Hardy Trees and Shrubs - an illustrated encyclopedia. Timber Press. Portland, Oregon. p. 352-356. 
55. Donauchem (2013a): Termékek. Propilén-glikol. http://www.donauchem.hu/Products--Solutions/ProductView.aspx?productId=105. 2013.04.21. 12:35

56. DonAUCHEM (2013b): Termékek. Etilén-glikol. http://www.donauchem.hu/Products--Solutions/ProductView.aspx?productId=1901. 2013.04.21. 12:56

57. DonaUCHEM (2013c): Termékek. Dietilén-glikol. http://www.donauchem.hu/Products--Solutions/ProductView.aspx?productId=94 2013.04.21. 11:39

58. DrANSFIELD, B. et al. (2014): Aphids on willow (Salix). http://influentialpoints.com/Gallery/Aphids_on_willow_Salix. 2014.01.14.18:48

59. Dreyer, E., Mauget, J. C. (1986): Conséquences immédiates et différées de périodes de sécheresse estivale sur le développement de jeunes noyers (Juglans regia L., cv. 'Pedro') : dynamique de croissance et dormance automno-hivernale des bourgeons. Agronomie 6. p. 639-650.

60. Dubois, P., Joyce, D. (1992): Preservation of fresh cut ornamental plant material with glycerol. Post Harvest Biology and Technology 2. p. 143-145.

61. EHRENDORFER, F. (1991): Evolution und Systematik. In: Strasburger, E.: Lehrbuch der Botanik. 33. Aufl. - Springer Vlg. p. 484-828.

62. Elert, G. (2007): Viscosity. The Physics Hypertextbook. 2007. október 2. http://hu.wikipedia.org/wiki/Etil\%C3\%A9nglikol. 2013.04.20. 20:40

63. EsCHRICH, W. (1981): Gehölze im Winter: Zweige und Knospen. Stuttgart - New York. Gustav Fischer Verlag. p. 104-115.

64. Evans, R. Y., Reed, M. S. (1990): Post Harvest Care of Specialty Cut Flowers. Proceedings from presentation at 1990 Association of Specialty Cut Flower Growers 3rd National Conference on Specialty Cut Flowers. Association of Specialty Cut Flower Growers, Inc. Oberlin. OH. USA.

65. FARKAS S. (szerk.) (1999): Magyarország védett növényei. Mezőgazda Kiadó, Budapest. p. 269.

66. FELHŐSNÉ VÁCZI E. (szerk.) (1999): Növényszervezettan. Budapest. KÉE. Kertészeti Kar jegyzet. p. 259-260.

67. FOLHOFFER Gy. (2005): Virágkötészetileg hasznosított fás szárú növények jelentősége Magyarországon. Diplomamunka. Budapesti Corvinus Egyetem, Kertészettudományi Kar, Dísznövénytermesztési és Dendrológiai Tanszék. p. 45. 
68. Francis, D., Sorrell D. A. (2001): The interface between the cell cycle and plant growth regulators: a mini review. Plant Growth Regul. 33. p. 1-12.

69. FrANK N. (2008): Az év fája. A törékeny füz (Salix fragilis L.) erdőművelési tulajdonságai. Erdészeti Lapok 143 (9) p. 276-277.

70. Freeman, D., Riou-Khamlichi, C., Oakenfull, E. A., Murray, J. A. H.(2003): Isolation, characterization and expression of cyclin and cyclin-dependent kinase genes in Jerusalem artichoke (Helianthus tuberosus L.). Journal of Experimental Botany. Vol. 54. Iss. 381. p. 303-308.

71. Funnell, K. A., MacKay, B. R. (1992): Comparative effects of Promalin and GA3 on flowering and development of Zantedeschia 'Galaxy'. Acta Horticulturae 337. p. 167175.

72. GASSNER (1918) : Cit in: SzAlai I. (1974): Növényélettan. II. kötet. Növekedés- és fejlödésélettan. Tankönyvkiadó. Budapest.

73. Gencsi L., Vancsura R. (1992): Dendrológia. Mezőgazda Kiadó. Budapest. p. 382-411.

74. Gilmour, S. J., Thomashow M. F. (1991): Cold acclimation and cold-regulated gene expression in ABA mutants of Arabidopsis thaliana. Plant Molecular Biology 16. p. $1233-1240$.

75. GlyCERINE USP/FCC Technical Bulletin. Dow Chemical U.S.A., 1989. Dow Chemical Company. Midland. MI. USA. Cit. KocH, M. (1995): Preserving Flowers and Foliage with Glycols and Dyes. A Manual for the Commercial Producer. Robert Koch Industries, Inc. Bennett. CO. USA. p. 61.

76. Godwin, B. J. (1986): Alberta Supernaturals - Selecting, Growing and Processing Ornamental Plants and Flowers. Olds College. Olds. Alberta. USA. p. 78.

77. GrIfFITHS, M. (1997): Index of Garden Plants. Macmillan. London. p. 1024-1028.

78. Grisvard, P., Chaudun, V. (1964): Le bon jardinier. 152e ed. T. II. Paris. La Maison Rustique. p. 1550-1552.

79. Gutierrez, C., Ramirez-Parra, E., Castellano M. M., Pozo, J. C. (2002): G1 to S transition: more than a cell cycle engine switch. Current Opinion in Plant Biology 5 (6). p. $480-486$.

80. HAMrick, D. (2004): Woody cuts: Booming. FloraCulture International 14 (2) p. 6. 
81. Harbaugh, B. K., Wilfret, G. J. (1979): Gibberellic acid (GA3) induces flowering in Caladium hortulanum 'Birdsay'. HortScience 14. p. 72-73.

82. Henzell R.F., BRISCOE, M.R., GRAVETt, I. (1991): Improving kiwifruit vine productivity with plant growth regulators. Acta Horticultureae, 297. p. 345-350

83. Henny, R. J. (1980): Gibberellic acid $\left(\mathrm{GA}_{3}\right)$ induces flowering in Dieffenbachia maculata 'Perfection'. HortScience 15. p. 613.

84. HENNY, R. J. (1983): Flowering of Aglaonema commutatum 'Treubii' following treatment with gibberellic acid. HortScience 18. p. 374.

85. Herter, F. G., Balandier, P., mauget, J. C., Rageau, R., Bonhomme, M. (1991): Conséquences des conditions climatiques durant la croissance estivale et la période de repos sur la capacité de croissance des bourgeons chez deux espèces fruitières tempérées: le pommier et le pêcher. In: Edelin, C. (szerk.): L'Arbre: biologie et développement. Naturalia Monspeliensia, Montpelier. p. 417-431.

86. HiLlier et al. (1974): Hillier's Manual of Trees \& Shrubs. Yelf Brothers. Winchester. England. p. 349-358.

87. Hillier, M. (1991): Virágkötészet. Novotrade Kiadó. Budapest. p. 196-202.

88. HoffmanN, M. H. A. (szerk.) (2000): List of names of woody plants. International standard. Boomteelt Praktijkonderzoek. Boskoop, The Netherlands. p. 331-336.

89. Hoffmann, M. H. A. (szerk.) (2005): List of names of woody plants. International Standard ENA 2005-2010. Applied Plant Research. The Netherlands. p. 604-610.

90. Homestead (2004): The Homestead Nursery. Catalogue. USA. p. 169-173.

91. Horvath, D. P., Anderson, J. V., ChaO, W. S. et al. (2003): Knowing when to grow: signals regulating bud dormancy. Trends in Plant Science 8 (11) p. 534-540.

92. Horvath, D. P., ChaO, W. S., Anderson, J. V. (2002): Molecular analysis of signals controlling dormancy and growth in underground adventitious buds of leafy spurge. Plant Physiology 128 p. 1439-1446.

93. НRотKÓ K. (1999): Gyümölcsfaiskola. Mezőgazda Kiadó. Budapest. p. 18-22.

94. Johnson, A. T., Smith, H. A. (1979): Plant names simplified. Landsmans Bookshop. Buckenhill, Bormyard Herefordshire. p. 96.

95. KAREL, L. (1973): Dried Flowers From Antiquity to the Present. The Scarecrow Press, Inc. Metuchen. NJ. USA. p. 184. 
96. KÁRPÁTI Z., TERPÓ A. (1968): Növényrendszertan. Második kötet. Mezőgazdasági Kiadó. Budapest. p. 13-27, 361-362.

97. Kelpak (2013): A gyártó cég honlapja. www.Kelpak.com. 2013.05.06. 8:48

98. KereszTeSI B. (1971): Magyar erdők. Második, bővített kiadás. Akadémiai Kiadó. Budapest. p. 342.

99. KIRÁLY G. (szerk.) (2009): Új magyar füvészkönyv. Magyarország hajtásos növényei. Határozókulcsok. - Aggteleki Nemzeti Park Igazgatóság, Jósvafő. 616 old.

100. Kirtikar, K. R., Basu, B. D., I. C. S., Blatter, E., Caius, J. F., Mhaskar, K. S. (1975): Indian medicinal plants. 2nd ed. Vol. III. Jayyed Press. Delhi, India. p. 2360-2366.

101. KISS F. (1944): A serevényfúz (Salix rosmarinifolia L.) monográfiája. Erdészeti Lapok 83 (7) p. 303-314.

102. KLINCSEK P. (1990): Virágkötő kalauz. Zrínyi Nyomda Kiadója. Budapest. p. 176.

103. KliPPART (1874): Cit in: Szalai I. (1974): Növényélettan. II. kötet. Növekedés- és fejlődésélettan. Tankönyvkiadó. Budapest. p. 139.

104. Kobayashi, K. D., Fuchigami, L. H., English, M. J. (1982): Modeling temperature requirements for rest development in Cornus sericea. Journal of the American Society for Horticultural Science 107. p. 914-918.

105. KoCH, M. (1995): Preserving Flowers and Foliage with Glycols and Dyes. A Manual for the Commercial Producer. Robert Koch Industries, Inc. Bennett. CO. USA. p. 1-133.

106. Kolster, P. (2003): Schnittgehölze (Gebr. Kolster B.V. Snijheesters), Holland katalógus, p. 34.

107. KosÁry J. (1999): Szerves Kémia. Egységesített egyetemi jegyzet. Kertészeti és Élelmiszeripari Egyetem, Élelmiszeripari Kar. Kémia és Biokémia Tanszék. Budapest. 17-18., 63-65. p.

108. KRÜSSMANN, G. (szerk.) (1986): Manual of Cultivated Broad-leaved Trees \& Shrubs. III. Timber Press. Portland, Oregon. p. 273-300.

109. LAKATOS F. (2008): A törékeny füz károsítói. Erdészeti Lapok 143 (7-8) p. 250-251.

110. LANG, G. A. (szerk.) (1996): Plant Dormancy: Physiology, Biochemistry and Molecular Biology. CAB International. Biddles. London. p. 47-243. 
111. Lang, G. A., Early, J. D., Martin, G.C., Darnell, R. L. (1987): Endo-, para-, and ecodormancy: physiological terminology and classification for dormancy research. Horticultural Science 22 p. 371-377.

112. Lavarenne, S., Barnola, P., Champagnat, P. (1980): Climats artificiels et dormance des bourgeons. I. Températures et dormance automnale chez le frêne (Fraxinus excelsior L.). Comptes-Rendus de l'Académie d'Agriculture de France. 20. p. 92-106..

113. Lewis, W. H., Elvin-Lewis, M. P. F. (1977): Medical Botany. Plants affecting man's health. Wiley \& Sons. New York. U.S.A. p. 150-152, 244, 276.

114. Li, C. Y., Vihera-Aarnio, A., Puhakainen, T., Junttila, O., Heino, P., Palva, E. T. (2003): Ecotype-dependent control of growth, dormancy and freezing tolerance under seasonal changes in Betula pendula Roth. Trees Struct. Funct. 17 p. 127-132.

115. Long, W. S. (1917): The Composition of Commercial Fruit Extracts. Transactions of the Kansas Academy of Science 28. p. 157-161.

116. LŐRINCZ A. (1999): A szőlő életszakaszai és évi biológiai ciklusa. In: BÉNYEI F., LÖRINCZ A., Sz. NAGY L.: Szőlőtermesztés. Mezőgazda Kiadó. Budapest. p. 134-135.

117. Magullion, S. (1977): A Guide by Plant Family to Foliage Preservation. Arnoldia. Nov/Dec 1977. Volume 37 (6). USA. p. 289-304.

118. Magyar L., Barancsi Z., Dickmann A., Hrotkó K. (2008): Application of biostimulators in nursery. Bulletin UASVM Horticulture 65 (1). p. 515.

119. MAJER A. (1966): Erdőmüveléstan I/B. - Fafajok. Kézirat. Erdészeti és Faipari Egyetem, Erdőmérnöki Kar. Jegyzetsokszorosító részleg. Sopron. p. 84-87.

120. MAROSI F. (1886): A kosárfonásra alkalmas füz tenyésztéséről. Erdészeti Lapok 25 (3) p. 214-223.

121. Mauget, J. C. (1981): Modification des capacités de croissance des bourgeons du noyer (Juglans regia L.) par application d'une température de $4{ }^{\circ} \mathrm{C}$ à différents moments de leur période de repos apparent. Comptes-Rendus de l'Academia des Sciences, Paris III 292. p. 1081-1083.

122. Mauget, J. C. (1983): Etude de la levée de dormance et du débourrement des bourgeons du noyer (Juglans regia L., cv. Franquette) soumis a des températures supérieures a $15{ }^{\circ} \mathrm{C}$ au cours de leur période de repos apparent. Agronomie 3 p. 745-750. 
123. Mauget, J. C., Rageau, R. (1988): Bud dormancy and adaptation of apple tree to mild winter climates. Acta Horticulturae 232. p. 101-108.

124. Metzger, J. D. (1996): A Physiological Comparison of Vernalization and Dormancy Chilling Requirement. In: Lang, G. A. (szerk.): Plant Dormancy: Physiology, Biochemistry and Molecular Biology. CAB INTERNATIONAL. Irrigated Agriculture Research and Extension Center. Washington State University. Professor, WA. USA. p. 147-155.

125. MolnÁR N. (2003): Aphidina koalíciók szerveződése diszkrét habitat foltokban. Ph.D. értekezés. Szeged. p. 114.

126. Mornya, P. M. P., FAng, Y. C., LI, H. Y. (2011): Chronological changes in plant hormone and sugar contents in cv. Ao-Shuang autumn flowering tree peony. Horticultural Science 38. p. 104-112.

127. Morrison, R. T., Boyd, R. N. (1959): Organic Chemistry. Allyn and Bacon, Inc. Boston. MA. USA. Cit. Koch, M. (1995): Preserving Flowers and Foliage with Glycols and Dyes. A Manual for the Commercial Producer. Robert Koch Industries, Inc. Bennett. CO. USA. p. 61.

128. Muromcev, G. Sz., Agnyisztyikova, V. N. (1976): Gibberellinek, a növények hormonjai. Mezőgazdasági Kiadó. Budapest p. 91-92.

129. NAGY B. (szerk.) (1980): Díszfák, díszcserjék termesztése és felhasználása. Kertészeti dendrológia. Mezőgazdasági Kiadó. Budapest. p. 412-424.

130. NAGY B. (szerk.) (1986): Növényházi dísznövények termesztése és hajtatása. Mezőgazdasági Kiadó. Budapest. p. 78-83.

131. Nagy B., Schmidt G. (1991): Kertészeti dendrológia. Budapest: KÉE Kertészeti Kar. p. 89-92., 280-283.

132. Newsholme, C. (2002): Willows. The Genus Salix. Timber Press. Portland, Oregon. USA. p. 1-224.

133. NowaK, J., Rudnicki, R. M. (1990): Postharvest Handling and Storage of Cut Flowers, Florist Greens, and Potted Plants. Timber Press, Inc. Portland. Oregon. USA. p. 44-52.

134. Ogawa, M., Hanada, A., Yamauchi, Y., Kuwahara, A., KarniYa, Y., Yamaguchi, S. (2003): Gibberellin biosynthesis and response during Arabidopsis seed germination. Plant Cell 15 p. 1591-1604. 
135. OKubA, H. (2000): Growth cycle and dormancy in plants. in: Viemont, J.D., Crabbe, J. (szerk.): Dormancy in Plants - From Whole Plant Behavior to Cellular Control. CABI. p. $1-22$.

136. Or, E., Vilozny, I., Eyal,Y., OGRodovitch, A. (2000): The transduction of the signal for grape bud dormancy breaking induced by hydrogen cyanamide may involve the SNFlike protein kinase GDBRPK. Plant Molecular Biology 43 p. 483-494.

137. Petrides, G. A., Wehr, J. (1998): Eastern Trees. Houghton Mifelin Company. Boston. New York. USA. 329-338 p.

138. PODANI J. (2003): A szárazföldi növények evolúciója és rendszertana. ELTE Eötvös Kiadó. Budapest. p. 160.

139. Polunin, O. (1981): Európa fái és bokrai. Gondolat Kiadó. Budapest. p. 30-36.

140. PRISZTER SZ. (1998): Növényneveink. Mezőgazda Kiadó. Budapest. p. 92-93, 489-490.

141. Propylene Glycol. Industrial. Technical Bulletin. 1990. ARCO Chemical Company. Newton Square. PA. USA. Cit. KocH, M. (1995): Preserving Flowers and Foliage with Glycols and Dyes. A Manual for the Commercial Producer. Robert Koch Industries, Inc. Bennett. CO. USA. p. 61.

142. Rallo, L., Martin, G. C. (1991): The role of chilling in releasing olive floral buds from dormancy. Journal of the American Society for Horticultural Science 116. p. 1058-1062.

143. Raven, P. H., Evert, R. F., EichHorn, S. E. (1986): Biology of Plants. 4th edition. Worth Pulishers, Inc. New York. NY. USA. Cit. KocH, M. (1995): Preserving Flowers and Foliage with Glycols and Dyes. A Manual for the Commercial Producer. Robert Koch Industries, Inc. Bennett. CO. USA. p. 61.

144. RBGE - Royal Botanical Garden of Edinburgh (2013): Flora Europaea. http://rbgweb2.rbge.org.uk/cgi-bin/nph-readbtree.pl/feout?FAMILY_XREF=Salicaceae $\&$ GENUS_XREF $=$ Salix \&SPECIES_XREF $=\& T A X O N \_N A M E \_X R E F=\& R A N K=$ 2013.10.30. $14: 30$

145. ReHDER, A. (1951): Manual of cultivated trees and shrubs. The Macmillan Company. New York. p. 82-111.

146. ReISER, R. A., LANGHAns, R. W. (1993): Cultivation of Zantedeschia species for potted plant production. Acta Horticulturae 337. p. 87-94. 
147. Richardson, E. A., Seeley, S. D., Walker, D. R. (1974): A model for estimating the completion of rest for 'Redhaven' and 'Elberta' peach trees. Hortscience 9. p. 331-332.

148. RuPPRECHT, H. (1966): Treiben und Verfrühen von Blütengehölzen. Nemuann Verlag. Berlin-Köpernick. p. 39.

149. SaCalis, J. N. (1988): Fresh (Cut) Flowers For Designs. Ohio Florists' Association. Columbus. OH. USA. Cit. KocH, M. (1995): Preserving Flowers and Foliage with Glycols and Dyes. A Manual for the Commercial Producer. Robert Koch Industries, Inc. Bennett. CO. USA. p. 61.

150. SAUTER, M. (1997): Differential expression of a CAK (cdc2-activating kinase)-like protein kinase, cyclins and cdc2 genes from rice during the cell cycle and in response to gibberellin. Plant J. 11.p. 181-190.

151. SchMidT G. (1995): Rügyhatározó. Budapest Kertészeti és Élelmiszeripari Egyetem, Dísznövénytermesztési és Dendrológiai Tanszék. p. 114-116.

152. SchMIDT G. (szerk.) (1991): Dendrológiai herbárium. KÉE Kertészeti Kar. Budapest. p. 91.

153. SCHMIDT G. (szerk.) (2002): Növényházi dísznövények termesztése. Mezőgazda Kiadó. Budapest. p. 96-114.

154. Schmidt G., Tóth I. (1996): Díszfaiskola. Mezőgazda Kiadó. Budapest. p. 606-608.

155. SCHMIDT G., TóTH I. (2003): Kertészeti Dendrológia. BKÁE, KTK, Dísznövénytermesztési és Dendrológiai Tanszék. Budapest. p. 63-66.

156. Schoot, C. (1996): Dormancy and Symplasmic Networking at the Shoot Apical Meristem. In: Lang, G. A. (szerk.): Plant Dormancy: Physiology, Biochemistry and Molecular Biology. CAB INTERNATIONAL. Irrigated Agriculture Research and Extension Center. Washington State University. WA. USA. p. 63.

157. Shaltout, A. D., Unrath, C. R. (1983): Rest completion model for 'Starkrimson Delicious' apple. Journal of the American Society for Horticultural Science 108. p. 957961.

158. SiMON T. (2000): A magyarországi edényes flóra határozója. Tankönyvkiadó. Budapest. p. 657-660.

159. SoÓ R. (1970): A magyar flóra és vegetáció rendszertani-növényföldrajzi kézikönyve. IV. köt. Akadémiai Kiadó. Budapest. p. 548-565. 
160. SzABÓ I. (2008): Az év fája. A törékeny füz kórokozói. Erdészeti Lapok 143 (5) p. 156157.

161. SzABÓ L., BotZ L. (1999): A füzfakéreg (Salicis cortex) szalicil-tartalma. Olaj, szappan, kozmetika 48 (5) p. 207.

162. Szabó V., HrotKó K. (2009): Biostimulátorok hatása Crataegus és Prunus anyanövényeken. LOV Tudományos Ülésszak Abstracts. BCE KTK. Budapest. p. 70.

163. SzAlai I. (1974): Növényélettan. II. kötet. Növekedés- és fejlődésélettan. Tankönyvkiadó. Budapest. p. 11-17., 139-144., 179-191.

164. Szalai J. (2001): Életjelenségek a kertben. Szaktudás Kiadó Ház. Budapest. p. 14., 82., 102-106.

165. Szalai J. (2007): Növényi hormonok általános jellemzése. Mezőgazdasági Kiadó. Budapest. p. 11-105.

166. Szalai J. (2009): A növényi élet feltételei a kertekben. História Alapítvány. Budapest. p. 17-187.

167. TERPÓ A. (szerk.) (1986): Növényrendszertan az ökonómbotanika alapjaival. II. Budapest Mezőgazdasági Kiadó. p. 528-531.

168. То́тн I. (1969): Díszfák, díszcserjék. Mezőgazdasági Kiadó. Budapest. p. 422-428.

169. TÓтH I. (2000): Dísznövényismeret virágkötőknek. Mezőgazda Kiadó. Budapest. p. 146148.

170. То́тн I. (2012): Lomblevelü díszfák, díszcserjék kézikönyve. Tarkavirág. Budapest. p. 547-565.

171. TREERNÉ WINDISCH M. (2005): Vágott barkának alkalmas hazai füzek változatosságának és eltarthatóságának vizsgálata. Diplomadolgozat. Budapesti Corvinus Egyetem, Kertészettudományi Kar, Dísznövénytermesztési és Dendrológiai Tanszék. p. 58.

172. TReERnÉ Windisch M. (2006): Magyar szárazvirág. Kertészet és Szölészet. 55. (1.) p. 1618.

173. TURCSÁNYI G. (szerk.) (2000): Mezőgazdasági Növénytan. Mezőgazdasági Szaktudás Kiadó. Budapest. p. 555.

174. UPOV (2003): International Union For The Protection Of New Varieties Of Plants. Willow (Salix). Guidelines For The Conduct Of Tests For Distinctness, Uniformity And Stability. Geneva. p. 1-21. 
175. Vaughan, M. J. (1998): The Complete Book of Cut Flower Care. Timber Press, Inc.. Portland, Oregon. USA. p. 103-108, 120.

176. VeliCH I. (szerk.) (2001): Növénygenetika. Mezőgazda Kiadó. Budapest. p. 36-41.

177. Veres A., Kiss E., Tóth Á., Tóth E., HeszKy L. (2005): Az etiléntermelés gátlásának hatása a szegfü (Dianthus caryophyllus) néhány gazdaságilag fontos tulajdonságára. Kertgazdaság 37. (4) p. 53-61.

178. ViTASSE, Y. (2013): Ontogenic changes rather than difference in temperature cause understory trees to leaf out earlier. New phytologist 198 (1) p. 149-155.

179. WenszKY Á. (szerk.) (1990): Virágkötészet. Mezőgazdasági Kiadó. Budapest. p. 139141.

180. White, F. B. (1891): Revision of the British willows. The Journal of the Linnean Society 27 p. $333-457$.

181. Williams, R. R., Edwards, G. R., CoOmbe, B. G. (1979): Determination of the pattern of winter dormancy in lateral buds of appels. Annals of Botany 44. p. 575-581.

182. YANG, G., READ, P. E. (1997): Plant growth regulators in the forcing solution influenced bud break and shoot elongation of dormant woody plant species. PGRSA Quarterly.25 (3) p. $145-152$.

183. ZuMDAHL, S. S. (1989): Chemistry. 2nd edition. University of Illionois. D. C. Heath and Company. Lexington. MA. USA. Cit. KoCH, M. (1995): Preserving Flowers and Foliage with Glycols and Dyes. A Manual for the Commercial Producer. Robert Koch Industries, Inc. Bennett. CO. USA. p. 61. 


\section{M1. Táblázatok jegyzéke}

1. TÁBLÁZAT: SZEGED KÖRNYÉKI CINEGEFÜZEK ALAKJAI (KISS, 1944)

2. TÁBLÁZAT: A KÍSÉRLETEKBEN SZEREPLŐ TAXONOK, BESZERZÉSÜK ÉS SZAPORÍTÁSUK HELYE ÉS IDEJE, VALAMINT A VELÜK ELVÉGZETT

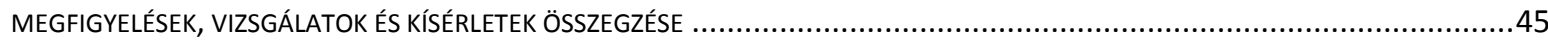

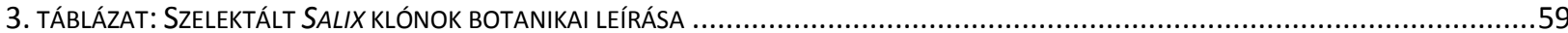

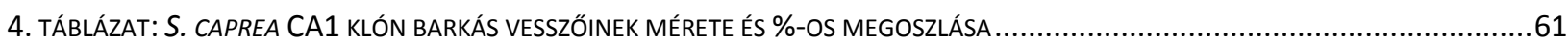

5. TÁBLÁZAT: S. PURPUREA PU2 KLÓN BARKÁS VESSZŐINEK MÉRETE ÉS \%-OS MEGOSZLÁSA ......................................................64

6. TÁBLÁZAT: S. ROSMARINIFOLIA RO1 KLÓN VESSZŐHOZAMA, MÉRETKATEGÓRIÁl ÉS EZEK \%-OS MEGOSZLÁSA 2006-2013 ................66

7. TÁBLÁZAT: S. ROSMARINIFOLIA RO2 KLÓN VESSZŐHOZAMA, MÉRETKATEGÓRIÁl ÉS EZEK \%-OS MEGOSZLÁSA 2006-2012 ................68

8. TÁBLÁZAT: S. ROSMARINIFOLIA RO3 KLÓN VESSZŐHOZAMA, MÉRETKATEGÓRIÁl ÉS EZEK \%-OS MEGOSZLÁSA (2008-2011) .............69

9. TÁBLÁZAT: S. ROSMARINIFOLIA RO4 KLÓN VESSZŐINEK \%-OS MEGOSZLÁSA MÉRET-KATEGÓRIÁK SZERINT 2013-BAN ......................71

10. TÁBLÁZAT: MEGPATTANÓ VIRÁGZATI RÜGYEK SZÁZALÉKOS ARÁNYA A ZÁRT RÜGYEKHEZ KÉPEST S. ROSMARINIFOLIA VESSZŐKÖN........85

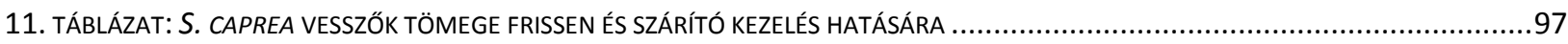

12. TÁBLÁZAT: S. ROSMARINIFOLIA VESSZŐK TÖMEGE FRISSEN ÉS SZÁRÍTÓ KEZELÉS HATÁSÁRA...................................................98

13. TÁBLÁZAT: S. CAPREA ÉS S. ROSMARINIFOIA VESSZŐK FOLYADÉK-FELVÉTELE A GLICERINES TARTÓSÍTÓ OLDATBÓL ............................99 


\section{M2. Ábrák jegyzéke}

1. ÁBRA: MAGAS TÖRZSRE OLTOTT S. INTEGRA 'KUROYANAGI' AZ ESSENI IPM KIÁLLítÁSON (FOTÓ: TREER, 2004) 12

2. ÁBRA: HOLLAND ÁRVERÉSI CSARNOKOKBAN FORGALMAZOTT SALIX VESSZŐK MENNYISÉGE 1996-2008 KÖZÖTT (FORRÁS: BLOEMISTERIJ)

3. ÁBRA: CIKLINFEHÉRJÉK ÉS CIKLINFÜGGŐ KINÁZ KOMPLEXEK HATÁSÁNAK HELYE A SEJTCIKLUS FOLYAMATÁNAK SZABÁLYOZÁSÁBAN (CELL

CyCle Regulation, 2013 alapján: TReerné) 34

4. ÁBRA: A GLICERIN ÉS NÉHÁNY SZÁRMAZÉKÁNAK KÉMIAI SZERKEZETE (FORRÁS: CSAPÓ ÉS CSAPÓNÉ, 2002)... . .37

5. ÁBRA: GLICERIN (FORRÁS: BRÜCKNER, 1961) .38

6. ÁBRA: A PROPILÉN-GLIKOL MOLEKULA SZERKEZETE (FORRÁS: DONAUCHEM, 2013A) …....................................................39

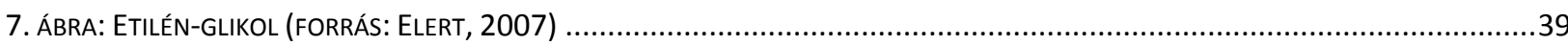

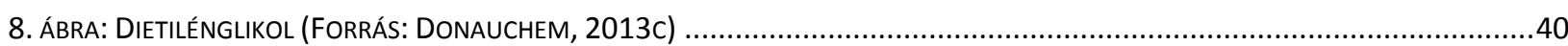

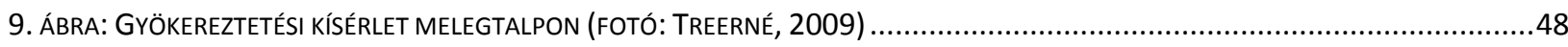

10. ÁBRA: GYÖKEREZTETÉSI KÍSÉRLET MELEGTALP NÉLKÜLI ASZTALON (FOTÓ: TREERNÉ, 2009) ................................................48

11. ÁBRA: BONITÁLÁSI SOR SALIX CAPREA DUGVÁNYOK GYÖKEREZTETÉSÉNEK ÉRTÉKELÉSÉRE (FOTÓ: TREERNÉ, 2010) .........................49

12. ÁBRA: BONITÁLÁSI SOR SALIX ROSMARINIFOLIA DUGVÁNYOK GYÖKEREZTETÉSÉNEK ÉRTÉKELÉSÉRE (FOTÓ: TREERNÉ, 2010) ..............49

13. ÁBRA: S. ROSMARINIFOLIA VESSZŐK KÜLÖNBÖZŐ NYÍLASZTÓ OLDATOKBAN (FOTÓ: TREERNÉ, 2006). .51

14. ÁBRA: SALIX VESSZŐK GLICERINES TARTÓSÍTÁSA (BALRA: S. PURPUREA VESSZŐK FELSZÍVATÁSA KÖZELRŐL, JOBBRA: S. P., S. CAPREA ÉS

S. CINEREA VESSZŐK KEZELÉSE SZOBAHŐMÉRSÉKLETEN) (BUDAÖRS, 2004. FOTÓ: TREERNÉ) ............................................53

15. ÁBRA: S. ROSMARINIFOLIA VESSZŐK A TARTÓSÍTÁSI KÍSÉRLETBEN (FOTÓ: TREERNÉ, 2008)..............................................53

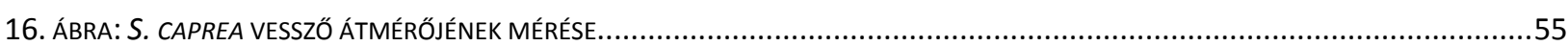

17. ÁBRA: A VESSZŐK HAJLITTÁSÁHOZ SZÜKSÉGES ERŐ MÉRÉSÉRE HASZNÁLT NÉGY FÉLE KÉZI ERŐMÉRŐ MŰSZER (FOTÓ: TREERNÉ, 2008).55

18. ÁBRA: S. ROSMARINIFOLIA VESSZŐ HAJLÍTÁSÁHOZ SZÜKSÉGES ERŐ MÉRÉSE KÉZI ERŐMÉRŐ MÜSZERREL (2008) ............................56

19. ÁBRA: S. ROSMARINIFOLIA ÉS S. CAPREA VESSZŐK FELSZÍVATÁSA (FOTÓ: TREERNÉ, 2013) ..............................................58

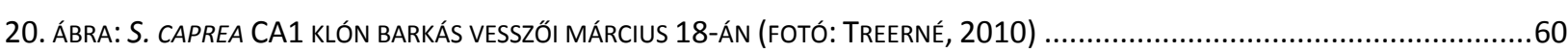

21. ÁBRA: S. CAPREA CA1 BARKA KERESZTMETSZET MURVAPIKKELYEKKEL ÉS PORTOKOKKAL (3X NAGYíTÁS, FOTÓ: REMÉNYI, 2013) .......61

22. ÁBRA: S. CAPREA CA1 KLÓN PORZÓS VIRÁGAI MEGFEKETEDETT MURVAPIKKELYEKKEL (2X NAGYíTÁS, FOTÓ: REMÉNYI, 2013)..........61

23. ÁBRA: S. CAPREA CA1 KLÓN VESSZŐHOZAMÁNAK SZÁZALÉKOS MEGOSZLÁSA MÉRET-KATEGÓRIÁK SZERINT .................................62

24. ÁBRA:HÁROM ÉVES S. CAPREA CA1 KLÓN TÖVEK OKTÓBER VÉGÉN (FOTÓ: TREERNÉ, 2010) ...............................................62

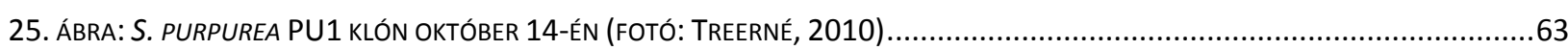

26. ÁBRA: S. PURPUREA PU2 (BALRA) ÉS PU1 (JOBBRA) KLÓNOK NOVEMBER ELEJÉN (FOTÓ: TREERNÉ, 2010) ..................................63

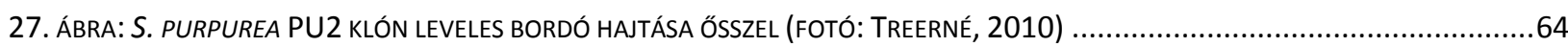

28. ÁBRA: A RÜGYPIKKELY SAJÁTOS LEVÁLÁSA S. PURPUREA ESETÉN (FOTÓ: TREERNÉ, 2008) ..................................................65

29. ÁBRA: S. ROSMARINIFOLIA RO1 KLÓN BARKÁS VESSZŐKKEL MÁRCIUS 10-ÉN (FOTÓ: TREERNÉ, 2006) ........................................65

30. ÁBRA: S. ROSMARINIFOLIA RO1 BARKÁS VESSZŐI MÉRET-KATEGÓRIÁK SZERINT (FOTÓ: TREERNÉ, 2011) ....................................66

31. ÁBRA: S. ROSMARINIFOLIA RO1 KLÓN VESSZŐINEK SZÁZALÉKOS MEGOSZLÁSA MÉRET-KATEGÓRIÁK SZERINT (2006-2013) .............67

32. ÁBRA: S. ROSMARINIFOLIA RO2 KLÓN RÖVID BARKÁS VESSZŐI (FOTÓ: TREERNÉ, 2006) ......................................................67

33. ÁBRA: S. ROSMARINIFOLIA RO2 KLÓN VESSZŐINEK SZÁZALÉKOS MEGOSZLÁSA MÉRET-KATEGÓRIÁK SZERINT (2006-2012) .............68

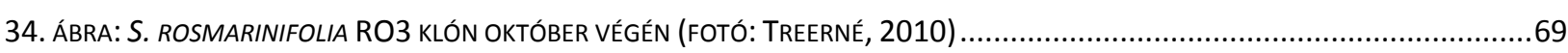

35. ÁBRA: S. ROSMARINIFOLIA RO3 MÉRET SZERINT VÁLOGATOTT BARKÁS VESSZŐI (FOTÓ: TREERNÉ, 2011)...................................69 


\section{DOI 10.14267/phd.2014004}

36. ÁBRA: S. ROSMARINIFOLIA RO3 KLÓN VESSZŐINEK SZÁZALÉKOS MEGOSZLÁSA MÉRET-KATEGÓRIÁK SZERINT (2008-2011) . .70

37. ÁBRA: S. ROSMARINIFOLIA RO4 KLÓN BORDÓ VIRÁGZATI RÜGYEI SZEPTEMBERBEN (FOTÓ: TREERNÉ, 2013) ...............................70

38. ÁBRA: S. ROSMARINIFOLIA RO4 DUGVÁNYOK GYÖKERESEDÉSE (FOTÓ: TREERNÉ, 2008) 71

39. ÁBRA: NOVEMBERI S. CAPREA DUGVÁNYOK (MELEGTALP NÉLKÜL, KE1/2 KEZELÉSSEL) 2 HÉTTEL A DUGVÁNYOZÁSt KÖVETŐEN (FOTÓ: TREERNÉ, 2010)

40. ÁBRA: KALLUSZKÉPZŐDÉS NES PORRAL KEZELT, DECEMBERBEN SZEDETT S. CAPREA DUGVÁNYOK TALPI RÉSZÉN MELEGTALP NÉLKÜL GYÖKEREZTETVE, A DUGVÁNYOZÁST KÖVETŐEN 5 HÉTTEL (FOTÓ: TREERNÉ, 2010).

41. ÁBRA: ÉLŐ, DE MÉG NEM GYÖKERESEDŐ, NES PORRAL KEZELT, DECEMBERBEN SZEDETT S. ROSMARINIFOLIA DUGVÁNYOK MELEGTALP NÉLKÜL, 5 HÉTTEL A DUGVÁNYOZÁST KÖVETŐEN (FOTÓ: TREERNÉ, 2010)

42. ÁBRA: NOVEMBERI S. ROSMARINIFOLIA DUGVÁNYOK (MELEGTALPON, NES PORRAL KEZELVE) 3 HÉTTEL A DUGVÁNYOZÁST KÖVETŐEN (FOTÓ: TREERNÉ, 2009).

43. ÁBRA: NOVEMBERI S. ROSMARINIFOLIA DUGVÁNYOK GYÖKERESEDÉSE BONITÁLÁSKOR. .76

44. ÁBRA: DECEMBERI S. ROSMARINIFOLIA DUGVÁNYOK GYÖKERESEDÉSE BONITÁLÁSKOR .76

45. ÁBRA: JANUÁRI S. ROSMARINIFOLIA DUGVÁNYOK GYÖKERESEDÉSE BONITÁLÁSKOR ...................................................77

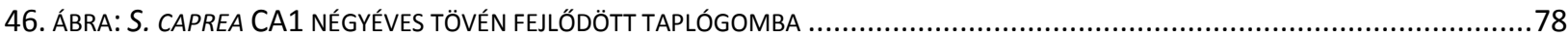

47. ÁBRA: SZÖVŐLEPKE HERNYÓK S. X SMITHIANA HAJTÁSÁN EGY DABASI TERMESZTŐNÉL (FOTÓ: DOBOS) ......................................79

48. ÁBRA: COSSUS COSSUS FIATAL LÁRVÁJA ÉS KÁRTÉTELE FÚZFÁBAN (FOTÓ: TREERNÉ, 2013) ..................................................79

49. ÁBRA: ZÁRT RÜGYEK A VÍZBEN LÉVŐ S. ROSMARINIFOLIA VESSZŐKÖN (FOTÓ: TREERNÉ, 2006).............................................81

50. ÁBRA: MEGPATTANÓ VIRÁGZATI RÜGYEK A VESSZŐ FELSŐ 5 CM-ÉN (FOTÓ: TREERNÉ, 2006). ............................................82

51. ÁBRA: EGY-EGY MEGPATTANÓ VIRÁGZATI RÜGY VÉKONY GYÖNGYBARKA VESSZŐN (FOTÓ: TREERNÉ, 2006) ...............................82

52. ÁBRA: GA ${ }_{3}$ HATÁSÁRA MEGPATTANÓ VIRÁGZATI RÜGYEK S. ROSMARINIFOLIA VESSZŐKÖN (FOTÓ: TREERNÉ, 2006) .......................83

53. ÁBRA: VASTAGABB ÉS VÉKONYABB GYÖNGYBARKA VESSZŐ FAKADÓ ÉS ZÁRT VIRÁGZATI RÜGYEKKEL (FOTÓ: TREERNÉ, 2006) ...........83

54. ÁBRA: VíZBEN TARTVA KIVIRÁGZÓ GYÖNGYBARKA VESSZŐ (FOTÓ: TREERNÉ, 2006) ........................................................84

55. ÁBRA: S. CAPREA VESSZŐK RUGALMASSÁGI MODULUSA (YOUNG-MODULUS) AZ 1. ÉS 2. MÉRÉSI IDŐPONTBAN.............................85

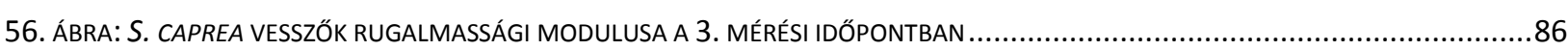

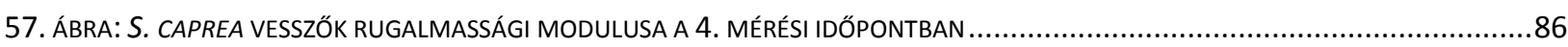

58. ÁBRA: KÉTFÉLE HÚTÉSES KEZELÉS EREDMÉNYEI S. CAPREA VESSZŐKNÉL AZ 5. MÉRÉSI IDŐPONTBAN ..........................................87

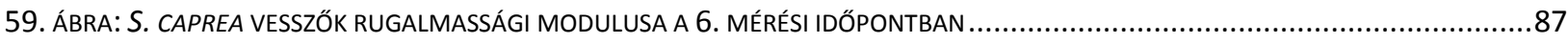

60. ÁBRA: GLICERINNEL FELSZÍVATOTT S. CAPREA VESSZŐK RUGALMASSÁGA A KÜLÖNBÖZŐ MÉRÉSI IDŐPONTOKBAN ..........................88

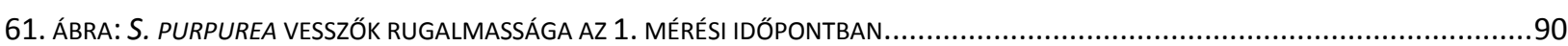

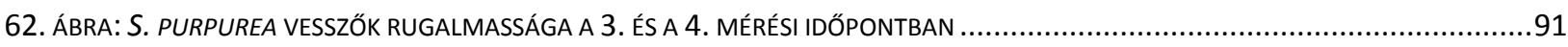

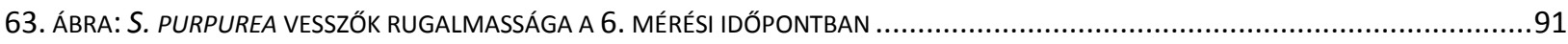

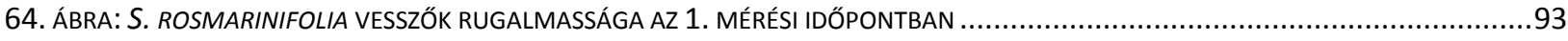

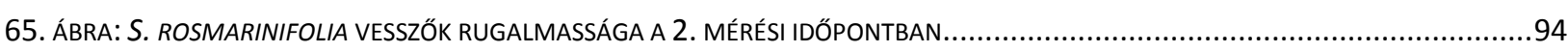

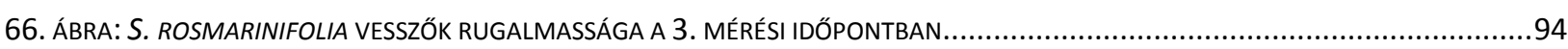

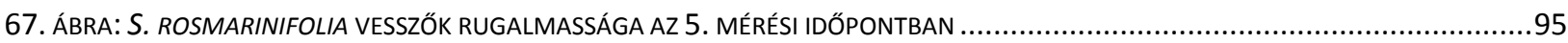

68. ÁBRA: SZÁRAZON TARTOTT ÉS GLICERINNEL FELSZÍVATOTT S. ROSMARINIFOLIA VESSZŐK (FOTÓ: TREERNÉ, 2008).........................96

69. ÁBRA: S. CAPREA ÉS S. ROSMARINIFOLIA VESSZŐK FRISS ÉS SZÁRÍTÁST KÖVETŐ TÖMEGÉNEK ALAKULÁSA ....................................98

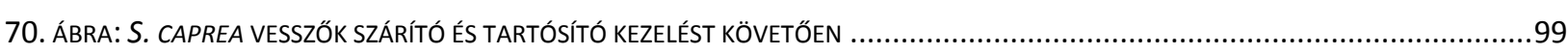


71. ÁBRA: S. CAPREA ÉS S. ROSMARINIFOLIA VESSZŐK FOLYADÉK-FELVÉTELÉNEK ALAKULÁSA AZ IDŐBEN 100

72. ÁBRA: SALIX KLÓNOK BARKÁS VESSZŐI (BALRÓL JOBBRA): CA1, PU2, PU2, RO1, RO2 (FOTÓ: TREERNÉ, 2010) .102

73. ÁBRA: NOVEMBERBEN SZEDETT ÉS DUGVÁNYOZOTT S. CAPREA DUGVÁNYOK GYÖKERESEDÉSE BONITÁLÁSKOR .105

74. ÁBRA: DECEMBERBEN DUGVÁNYOZOTT S. CAPREA GYÖKERESEDÉSE A BONITÁLÁS IDŐPONTJÁBAN. .106

75. ÁBRA: S. ROSMARINIFOLIA DUGVÁNYOK GYÖKERESEDÉSE NOVEMBERBEN, DECEMBERBEN, ÉS JANUÁRBAN VÉGZETT GYÖKEREZTETÉSI KÍSÉRLETEKBEN A KÜLÖNBÖZŐ KEZELÉSEK HATÁSÁRA 106

76. ÁBRA: A MEGPATTANÓ VIRÁGZATI RÜGYEK SZÁZALÉKOS ARÁNYA A ZÁRT RÜGYEKHEZ KÉPEST S. ROSMARINIFOLIA VESSZŐKÖN VÍZBEN, 1,5\%o-ES, ÉS 6\%o-ES GA 3 -AT TARTALMAZÓ NYÍLASZTÓ OLDATOKBAN (TREERNÉ, 2006) .108

77. ÁBRA: KÜLÖNBÖZŐ VESSZŐSZÍNŰ ÉS BARKAFORMÁJÚ S. CAPREA KLÓNOK (FOTÓ: TREER, 2004) .143

78. ÁBRA: KÜLÖNBÖZŐ S. PURPUREA BARKA FORMÁK (FOTÓ: TREER, 2004) .144

79. ÁBRA: VIRÁGZÓ S. PURPUREA (FOTÓ: TREER, 2004) .145

81. ÁBRA: NAGYOBB PORZÓS ÉS KISEBB TERMŐS BARKÁK S. ROSMARINIFOLIA VESSZŐKÖN (FOTÓ: TREER, 2004) .146

80. ÁBRA: TAPOLCA KÖRNYÉKÉN GYŰJTÖTT KÜLÖNBÖZŐ VESSZŐSZÍNŰ GYÖNGYBARKA KÖTEGEK (FOTÓ: TREER, 2004) .146

82. ÁBRA: DeCEMBERBEN SZEDETt ÉS DUGVÁNYOZOTT S. CAPREA DUGVÁNYOK (MELEGTALP NÉLKÜL, KE1/2 KEZELÉSSEL) 5 HÉTTEL A DUGVÁNYOZÁST KÖVETŐEN (FOTÓ: TREERNÉ, 2010)

83. ÁBRA: NES OLDATTAL KEZELT, DECEMBERBEN SZEDETT S. CAPREA DUGVÁNYOK KALLUSZKÉPZÉSE MELEGTALP NÉLKÜL, 5 HÉTTEL A DUGVÁNYOZÁST KÖVETŐEN (FOTÓ: TREERNÉ, 2010). 160

84. ÁBRA: KELPAK -KAL FÉL ÓRÁN KERESZTÜL FELSZÍVATOTT, NOVEMBERBEN SZEDETT S. CAPREA DUGVÁNYOK GYÖKERESEDÉSE MELEGTALPON, 2 HÉTtEL A DUGVÁNYOZÁSt KÖVETŐEN (FOTÓ: TREERNÉ, 2009). .162

85. ÁBRA: KELPAK -KAL 8 ÓRÁN KERESZTÜL FELSZÍVATOTT, DECEMBERBEN SZEDETT S. ROSMARINIFOLIA DUGVÁNYOK MELEGTALP NÉLKÜL, ÖT HÉTTEL A DUGVÁNYOZÁST KÖVETŐEN (FOTÓ: TREERNÉ, 2010) 168

86. ÁBRA: NOVEMBERBEN SZEDETT ÉS DUGVÁNYOZOTT S. ROSMARINIFOLIA DUGVÁNYOK (MELEGTALPON, NES PORRAL KEZELVE) 3 HÉTTEL A DUGVÁNYOZÁST KÖVETŐEN (FOTÓ: TREERNÉ, 2009) .173 


\section{M3. Füz fajok néhány egyéb felhasználási területe}

A gyógyászati szempontból fontos fenol-glikozidok, ezek közül is a legfontosabb szalicil miatt, mely a fajok kérgében (Salicis cortex) található, a füznek jelentős szerepe van a kertészet gyógynövénytermesztési ágazatában is. A legtöbb szalicil a következő füzfajokra jellemző: Salix viminalis L. (5\% körül), S. purpurea L. (4\% körül), S. alba L. subsp. vitellina (L.) Arcang. (34\%) és S. fragilis L. (2-3\%) [SZABÓ és BOTZ, 1999]. A szalicin a szintetikus szalicilsavkészítmények (Aspirin, Kalmopyrin) természetes elődje. Észak-Amerikában kétségkívül az Aspirin a legszélesebb körben alkalmazott drog az alkohol és a nikotin után [LEWIS és ELVINLEWIS, 1977]. A fehér füz ( $S$. alba L.) kérgéből sárga színű festékanyag is nyerhető. Az angolul törpe barkafüznek vagy prérifüznek nevezett S. humilis Marsh. gyökereit a Menominee indiánok hasi görcsök kezelésére használták [LEWIS és ELVIN-LEWIS, 1977]. Szintén gyógynövénynek számítanak abból a szempontból is, hogy a méhek által gyüjtött gyógyhatású propolisznak a füzés nyárfajok rügyeit védő gyantaanyag fontos összetevője. Iránban hagyományos nemzeti gyógyszerként tartják számon a $S$. aegyptiaca L. virágzatából (nektárjából) készült édesített szirupot [MiRMAZLOUM, 2010, szóbeli közlés]. Ez utóbbi fajt úgy is említik India flórájának leírásában, mint ,az indiai S. caprea”-t [ANIL et al., 2013]. Ugyanakkor az India gyógynövényeit összesítő lexikonban nem szerepel $S$. aegyptiaca, helyette a $S$. caprea fajt említi a könyv, és felsorolja számtalan gyógyhatását, illetve a belőle gyártott gyógyhatású készítményeket [KIRTIKAR et al., 1975]. A füzek fája kisebb értékü puhafa, mely elsősorban papírgyártásra alkalmas, de készítenek belőle fogpiszkálót, valamint a hagyományos angol sport, a krikett ütőjét is [TURCSÁNYI, 2000; LEWIS és ELVIN-LEWIS, 1977; NEWSHOLME, 2002]. 


\section{M4. Fủz fajták néhány jellegzetes tulajdonsága UPOV (2003) irányelvek alapján}

\begin{tabular}{|c|c|c|c|}
\hline Minőség & Növényrész & Lehetséges tulajdonságok & Példa \\
\hline \multirow[t]{4}{*}{ QL } & \multirow[t]{4}{*}{ Növény ivara } & kétlaki termős & Tora \\
\hline & & kétlaki porzós & Björn \\
\hline & & egylaki uniszex (kétivarú) & \\
\hline & & egylaki hermafrodita (hímnős) & \\
\hline \multirow[t]{5}{*}{ QN } & \multirow{5}{*}{$\begin{array}{l}\text { Növény: ta- } \\
\text { vaszi lombo- } \\
\text { sodása }\end{array}$} & nagyon korai & $\mathrm{I}-3-58$ \\
\hline & & korai & Godesberg \\
\hline & & normál & Metz \\
\hline & & késői & F-65-02 \\
\hline & & nagyon késői & Mangahn \\
\hline \multirow[t]{5}{*}{$\overline{P Q}$} & \multirow{5}{*}{ Vessző állása } & egyenes & Bredevoort \\
\hline & & enyhén hajlott & $\mathrm{I}-3-58$ \\
\hline & & közepesen hajlott & Mittlerer Inn V \\
\hline & & erösen hajlott & 75/64 (S. fragilis L.) \\
\hline & & csavarodott & Tortuosa \\
\hline \multirow[t]{10}{*}{ PQ } & \multirow{10}{*}{$\begin{array}{l}\text { Vesszőszín a } \\
\text { vessző kö- } \\
\text { zépső harma- } \\
\text { dán, a napos } \\
\text { oldalon }\end{array}$} & sárga & \\
\hline & & narancs & Gelbe Dotterweide \\
\hline & & szürke & \\
\hline & & szürkészöld & Stott 10 \\
\hline & & világoszöld & Graupa 34 \\
\hline & & közepesen zöld & 259/64 (S. x smithiana) \\
\hline & & barnászöld & $\mathrm{I}-3-58$ \\
\hline & & szürkésbarna & \\
\hline & & vörösesbarna & Altenstadt 4 \\
\hline & & barna & $\begin{array}{l}\text { Straubinger } \\
\text { Baumweide II }\end{array}$ \\
\hline \multirow[t]{5}{*}{ QN } & \multirow[t]{5}{*}{$\begin{array}{l}\text { Vessző szö- } \\
\text { rözöttsége }\end{array}$} & $\begin{array}{l}\text { kopasz, vagy minimális mértékben } \\
\text { szőrözött vesszők }\end{array}$ & Tordis \\
\hline & & gyengén szőrözött & Björn \\
\hline & & közepesen szőrözött & Eva \\
\hline & & erősen szőrözött & Nils \\
\hline & & nagyon erősen szőrözött & Osk \\
\hline \multirow[t]{5}{*}{ QN } & \multirow{5}{*}{$\begin{array}{l}\text { Vesszőkön a } \\
\text { lenticellák } \\
\text { kiemelkedé- } \\
\text { sének mérté- } \\
\text { ke }\end{array}$} & nincs / enyhén kiemelkedő lenticellák & Hild \\
\hline & & kismértékben kiemelkedő lenticelllák & Osk \\
\hline & & közepesen kiemelkedő lenticellák & Olaf \\
\hline & & erősen kiemelkedő lenticellák & Sherwood \\
\hline & & nagyon erősen kiemelkedő lenticellák & \\
\hline \multirow[t]{5}{*}{ PQ } & \multirow{5}{*}{$\begin{array}{l}\text { Vesszőn: a } \\
\text { hajtásrügyek } \\
\text { színe }\end{array}$} & világoszöld & \\
\hline & & zöld & Stott 10 \\
\hline & & zöldesbarna & Gustaf \\
\hline & & barna & Orm \\
\hline & & vörösesbarna & Jorum \\
\hline \multirow[t]{5}{*}{ QN } & \multirow{5}{*}{$\begin{array}{l}\text { Vessző: a } \\
\text { hajtásrügyek } \\
\text { szőrözöttsége }\end{array}$} & kopasz vagy alig szőrös & Flamingo \\
\hline & & kicsit szőrös & Sherwood \\
\hline & & közepesen szőrös & Nils \\
\hline & & erősen szőrös & Stott 10 \\
\hline & & nagyon erősen szörös & Osk \\
\hline
\end{tabular}




\section{M5. Barkafüzek hazai termesztése és kínálata}

Az antik idők óta felhasznált örökzöldek mellett számos lombhullató díszfa és díszcserje szolgáltat úgynevezett vágott zöldet, illetve különleges, fás szárú vágott virágot. Lombnyerés céljából sok fontos faj esetében (pl. Quercus cerris, Q. pubescens, Fraxinus ornus, Parthenocissus) mégsem létesítenek ültetvényeket, azokat sarjerdőkben gyüjtik. Számos nagy mennyiségben, vázadíszként felhasznált fajt nem vásárolnak, hanem házikertekben termesztenek. Különleges, fás szárú vágott virág előállítás céljából csak néhány fajt, illetve ezek fajtáit termesztik (pl. Cerasus glandulosa 'Alboplena' és 'Sinensis'; Amygdalus triloba 'Multiplex', Forsythia x intermedia 'Densiflora', 'Primulina', 'Spectabilis', 'Arnold Giant', stb.). Különleges vágott virág vágása céljából történő termesztésre jól előkészített talajba, 1,5 x 1,5 m távolságra telepítik, 4500 növény ültethető egy hektárra. A faiskolából 3-4 ágas cserjéket kell kiültetni, ezek vesszőit 10-15 cm-es csapokra kell visszavágni. A kétéves növények 5-7 db, a hároméves tövek 10-12 db, 1-1,5 m hosszú hajtatásra alkalmas vesszőt adnak. A Forsythia x intermedia fajtákból kétféle minőségü vágott virágot lehet nevelni: teljes hosszukban berakódott, elágazás nélküli egyéves vesszőket, valamint rövid, virágrügyekkel teli oldalhajtásokkal berakódött kétéves galylyakat. A Viburnum opulus 'Roseum' és a Weigela florida a Forsythia-hoz hasonlóan termeszthető, virágrügyeik a másodéves gallyakon fejlődnek. Nyugat-Európában fás szárú vágott virág termesztés céljából termesztik még a Deutzia, Chaenomeles, Corylus, Cornus mas fajokat és fajtáikat [NAGY, 1980; NAGY és SCHMIDT, 1991]. Hollandiában az egyik elsőként különleges (fás szárú) virágokra specializálódott termesztőtelep, a Gebr. Kolster Boskoop város mellett létesült PETER KOLSTER vezetésével. Az alapító több mint egy évtizedes faiskolai tevékenysége után, az 1970-es évek végén határozta el, hogy különleges vágott virág előállítás céljából is nevel fás szárú növényeket. A cég 2001-ben adta fel véglegesen az eredeti faiskolai tevékenységet, hogy teljesen a fás vágott növényekre álljanak át [HAMRICK, 2004].

\section{Salix fajok barkás vesszőinek felhasználása}

A kecskefüz (S. caprea) a leggyakrabban alkalmazott „húsvéti barka” [SIMON, 2000], Tóтн (1969) szerint az egyik legszebb barkájú füz. TóTH (2000) a tél végét, a tavasz kezdetét jelző növényként ír róla, és említi a barkaszentelést, felhasználását a húsvéti ünnepkörben. Megjelenik oltárok díszítésénél, csokrokban és asztaldíszekben [TÓTH, 2000]. Napjainkban barkás vesszői egyre kedveltebbek a virágkötészetben, Nyugat-Európában rendkívül divatos, termesztésével érdemes lenne foglalkozni. Elsősorban porzós egyedei alkalmasak díszítésre, mert azoknak nagyobb, dekoratívabb a barkája, de ismert nőivarú fajtája is [RETKES, szóbeli közlés]. A barka- 
termelésre alkalmas füzek közül NAGY (1980) szintén a hímivarú S. caprea 'Mas'-t és egyéb nagy barkájú fajokat tart alkalmasnak szabadföldi vágásra, valamint vesszők hajtatására.

A gyöngybarka (S. rosmarinifolia) То́тН (2000) szerint kis mérete miatt elsősorban ajándéktárgyak díszítésére alkalmas, különösen Húsvéthétfőn ajándékozáskor, vagy jellegzetes tavaszi virágokkal (pl. nárcisz, jácint) társítható. Megszárítva bármikor felhasználható. NAGY (1980) és KÁRTPÁTI és TERPÓ (1968) is említi, hogy vesszője gyüjtés útján kerül forgalomba.

A rekettyefüzröl (S. cinerea) BARTHA (1999) azt írja, hogy részben ez a faj szolgáltatja a húsvéti barkát.

\section{Salix fajok barkás vesszőként való termesztésének és kínálatának vizsgálata Magyarországon}

Salix taxonok barkás vessző előállítás céljából történő termesztéséről elsősorban azok a gyüjtők rendelkeztek tapasztalatokkal, akik a valamilyen szempontból érdekesebb klónokat sikeresen leszaporították, és termesztik saját kertjükben. A szigetszentmiklósi Flora Hungaria nagybani virágpiacon eleinte inkább gyanakodva, óvatosan, majd az évek múlásával egyre készségesebben osztották meg velem tapasztalataikat ezek a gyüjtők, illetve termesztők. Rajtuk kívül három helyen találtam az országban olyan kertészeteket, ahol komolyabban foglalkoztak különleges (fás szárú) vágott virágok, ezek között Salix taxonok termesztésével. Így 2005. nyár elején meglátogattam a szolnoki C\&L Flora Kft. pályázati pénzből telepített modern dísznövény vágótelepét, majd az évek során rendszeresen jártam le hozzájuk Szolnokra. A Veszprém megyei Egeralján Zajcsek Szabolcs kertészmérnök mutatta be kertészetét 2008 februárjában, ahol a tőlem kapott $S$. purpurea és $S$. rosmarinifolia dugványokból fejlődött növényeket nevelte. Végül a Móri Flora Kertészetet (Mór, Fejér megye) volt szerencsém megtekinteni, ahonnan igen dekoratív különleges (fás szárú) vágott virágok kerülnek a Flora Hungaria virágpiacra. A kertészetet a tulajdonos és felesége mutatta be 2009 nyarán.

A barkás füzvesszők hazai kínálatát 2004 és 2013 között, elsősorban az ország legnagyobb nagybani virágpiacán, a szigetszentmiklósi Flora Hungaria árusai között mértem fel. Ide az ország egész területéről érkeznek eladók, termesztők, importőrök és gyüjtők egyaránt. Ezen túl budapesti és vidéki virágüzletekben is jártam, ahol különösen az árak alakulása volt érdekes. A piacon megjelenő kínálat elemzésének céljából a nagybani virágpiacra minden évben januártól Húsvétig jártam ki heti rendszerességgel. Felmértem a piacon megjelenő barkák összetételét fajok szerint, valamint adatokat gyüjtöttem az eladásra kínált barkák mennyiségéről, méretéről, gyüjtési vagy termesztési helyéröl. Igyekeztem felmérni a fajokon belül megjelenő változatokat, például a különleges barkájú vagy vesszőszínü egyedeket, valamint az árakat is figyelemmel 
kísértem. Sokat beszélgettem az árusokkal, gyüjtőkkel, akik számos tudnivalót, érdekességet is megosztottak velem.

\section{A barkás füzvesszők kínálata, adatok Salix fajok barkás vessző előállítás céljáből történő termesztéséhez}

Az országban a különleges, fás szárú vágott virágot is termesztő kertészetek látogatása során azt tapasztaltam, hogy a termesztés technológiája, az áru kezelése még kiforratlan, inkább kísérleti stádiumban van. A Szolnokon 2004-ben létesített dísznövény vágótelepet elsősorban a virágcsokrokat gyártó, és azokat multinacionális nagyáruházakban forgalmazó vállalkozás saját felhasználásra szánta. A Tisza partjára telepített $S$. purpurea klónokból nevelt ültetvényt már felhagyták, mert munkaerő hiányában nem győzték visszavágni, és a kezelhetetlenül nagyra nőtt bokrokon már nem termett dekoratív barkás vessző.

Egeralján közel $8000 \mathrm{~m}^{2}$ területen folyik a termesztés. Rendelkezésre áll fóliasátor, hütőtároló és egyéb raktár céljára szolgáló épületek. A 2006 tavaszán tőlem kapott, $20 \mathrm{~cm}$ hosszú $S$. purpurea dugványokat a termesztő félbevágta, hogy a növények mennyiségét megduplázza, és így dugványozta ezeket május 4-én. A dugványokat három szabadföldbe ültetett kivételével cserépbe tette. Az eredés $100 \%$-os volt, de mivel a következő évben nem ért rá kiültetni, a fóliasátorban, a 11 cm-es műanyag konténerekben sínylődő növények közül több kipusztult. Mivel a begyökeresedett növényeket továbbra is a fólia alatt tartotta, az eredetileg bordó, és egy másik klónnál zöld vesszőszín nem alakult ki, a növények szára szürkésbarna maradt. A kísérletező kedvü termesztő 2007 tavaszán a Flora Hungaria nagybani piacon gyüjtőktől vásárolt $S$. rosmarinifolia dugványokat is dugványozott, összesen 10 ezer darabot, 140 db-ot sejttálcánként, de a dugványok nagy része kipusztult. 2007. május 10-én Egeralja határában 1 ha energiafüzt szaporított a termesztő, melynek eredése meghaladta a 95\%-ot, és az első évben 1,5 m hosszú vesszőket hozott. Szekszárd közelében is megnéztem egy energiafüz ültetvényt 2007. november végén, ahol a töveket ugyanazon a tavaszon ikersorosan telepítette az Aranyfürt TSZ. Ez a japánfüz azonban igen rosszul, 50\%-osan eredt meg.

\section{Salix caprea vesszők kínálata Magyarországon}

Ebből a fajból a legnagyobb a kínálat hazánkban, az országban szinte mindenütt megtalálható. Sok helyről gyüjtik, és ezt a fajt termesztik a legtöbben. Már január közepén-végén megjelentek vesszői a piacon, főleg Kaposvár környékén gyüjtik, Belső-Somogyból, valamint Zala megyéből hoznak sokat. A roma gyüjtők a barkás vesszőket „cicamaca” névvel illetik. Ez a kifejezés tulajdonképpen nem áll messze a barka angol, francia vagy német nevétől, ugyanis mindháromban 
szerepel a cica szó (catkin, chaton, kätzchen). Az értékesítési szezon kezdetén inkább gyüjtött árut hoznak, a saját kertjében termő vesszőket mindenki később szedi le, mikor az a legszebb formáját mutatja. A természetben azonban verseny van, a gyüjtők sokszor egymás elől vágják a vesszőket, ezért amint az értékesítésre alkalmas stádiumot megközelíti, azonnal vágják, és a pincében tárolják egy ideig, vagy azonnal hozzák értékesíteni. Az ilyen, általuk erdei barkának nevezett vessző (szemben az otthon termesztett kertivel) általában jóval elágazóbb, bokrosabb.

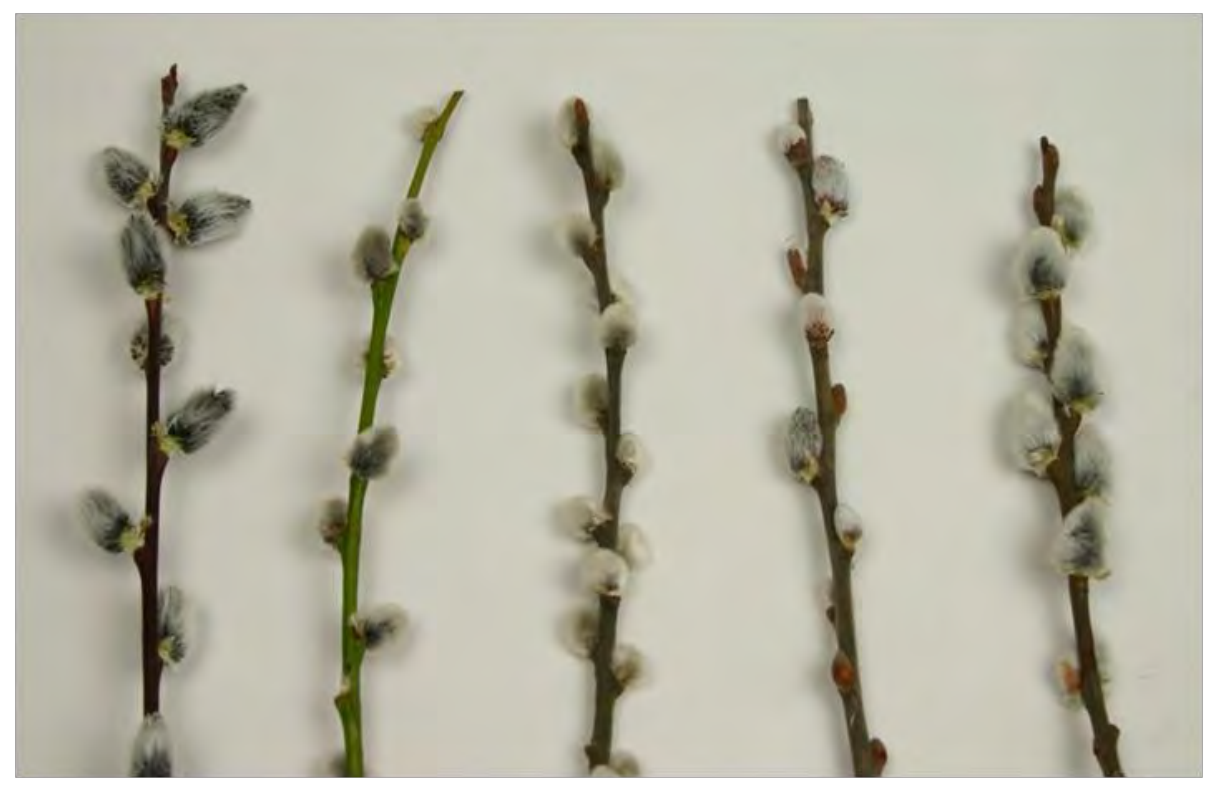

77. ábra: Különböző vesszőszínü és barkaformájú $S$. caprea klónok (fotó: Treer, 2004)

Gyakori az is, hogy a gyüjtők ugyanoda járnak vissza, és az évről évre ily módon metszett füzek hosszú, el nem ágazó vesszőket hoznak. Március elsején például találtam $170 \mathrm{~cm}$ hosszú kecskefüz vesszőket, melyeken alig volt elágazás, és ezeket gyüjtés útján szerezték be.

A Csepel-sziget déli részén is jelentős füzes található, innen főleg egy makádi család hoz vesszőket. Az állományban találtak egy sötét, fekete barkájú kecskefüz bokrot, melyhez évrőlévre visszajártak, de mindössze 15-20 vesszőt tudtak belőle hozni.

A sokféle kecskefüzet (77. ábra) vizsgálva volt alkalmam megfigyelni, hogy a portokok viszonylag korai fejlettségi stádiumban rózsaszínek. Ez a természetben nem feltűnő, akkor lehet megfigyelni, ha a korán begyüjtött barkákról a rügypikkelyt idő elött kézzel leszedegetik ilyenkor teljesen rózsaszínű barkákat is láthatunk. Abban az esetben, mikor annyit fejlődött, hogy félig kilátszik a rügypikkely alól, és aztán szedik azt le róla, gyakran csak a barka tövét díszíti egy rózsaszínű folt. Ez különlegesen dekoratív, de semmiképpen sem gazdaságos a rügypikkelyek leszedegetése, ezért ilyen vesszőt csak „ráérős” gyűjtőtől vásárolhatunk, üzemi előállítása nem volna lehetséges. 
A vesszőket csomóba kötik, egy csomóba általában 10 szálat tesznek. Ezeket aztán kötegelik, egy kötegbe 3, 5, vagy 10 csomó kerül. A vesszők ára változó, elsősorban mérettől függ. A hosszabb, 1-1,5 métert meghaladó szálakat 2004-ben 35-50 Ft-os áron értékesítették, ez az ár közel tíz éven keresztül stagnált, 2013-ban inkább kicsit csökkent, ezek a vesszők 20-30 Ft-ért találtak gazdára. Az extra nagy méretü, esetenként a 3 m hosszúságot is elérő vesszőket akár több száz forintért kínálták 2004-ben, 2013-ban ezekért körülbelül 200 Ft-ot lehetett kapni. Az 50-100 cm hosszú vesszők ára 5-15 Ft között változott, ennek megfelelően egy 10 csomós köteget 500-1500 Ft-ért értékesítettek a vizsgált időintervallumban. Egyre többen szaporítják és termesztik kertjükben vagy földjükön a $S$. caprea 'Silberglanz' nevü, fényes vesszőjü, igen nagyméretü, ezüstös, rendkívül dekoratív barkájú, kifejezetten barkás vessző termesztés céljából szelektált kecskefüz fajtát. Körülbelül $60 \mathrm{~cm}$-esre hagyott alacsony törzsön, minden évben legfeljebb $10 \mathrm{~cm}$-es, rövid csapokra visszavágva nevelik. Erről változatos hosszúságú barkás vesszőket hoznak, és rendszerint mind el tudják adni. Általános szabályként fogadható el az árképzésnél, hogy ahány centiméter hosszú a vessző, annyi Forintba kerül darabja. Így a $30 \mathrm{~cm}$-es rövid vesszőkből álló csomó 300 Ft-ba kerül, a 2 m hosszú vesszőkből 2000 Ft egy tízszálas csomó (2013-as adatok).

\section{Salix purpurea vesszők kínálata Magyarországon}

Ezt a fajt a szakirodalomban [SCHMIDT, 1995] nem sorolják a barkafüzek közé, azonban az előbbi két fajjal közel egy időben, lombfakadás előtt virágzik, így barkás vesszői is ugyanakkor jelennek meg, melyek virágkötésze-

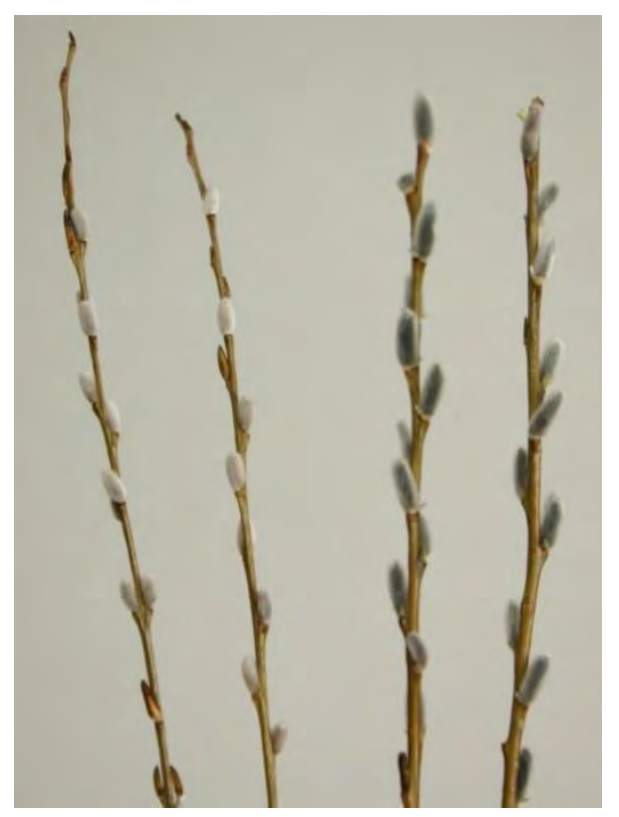

78. ábra: Különböző $S$. purpurea barka formák (fotó: Treer, 2004) ti célra felhasználhatók. A barka alakja lényegesen eltér az előző kettőtől, a rügypikkely alól előbújó virágzata átlagosan $20 \mathrm{~mm}$ hosszú, keskeny, hengeres (78. ábra). Kifejezetten folyópartok növénye, csak közvetlenül a víz mellett él meg. Szintén Zala és Somogy megyékből hoznak sokat. Vesszője az előző két fajjal ellentétben teljesen kopasz, és ez azért előnyös, mert a por kevésbé tapad meg rajta, a fényes vessző dekoratívabb, mint a molyhos. A vesszők színe a faj nevével ellentétesen leggyakrabban sárga, de találtam vörös vesszőjűeket is. A gyüjtők ezt a fajt vesszöbarka, füzbarka vagy füzvesszö néven ismerik. Számukra ez „,a füz”, a többi barkás Salix fajt csak barkának nevezik (és nem akarták elhinni, hogy azok is füz fajok), a füz magyar nevet csak ennél a fajnál használják. A kecskefüzhöz hasonlóan ennek a fajnak is pirosak a portokjai éretlen állapotban, és ez az állapot hosszabb ideig, a rügypikkely takarásából előbújt barkákon is megmarad. Ez az egészen mélyvörös szín a virágzás előtti állapotban rendkívül mutatós, sajnos 
ekkor már nem értékesíthetők a vesszők. Virágzáskor a hosszú barkák meggörbülnek (79. ábra). Amikor még csak kezdenek elöbújni a rügypikkely alól, és nem látszik teljesen hosszúkás alakjuk, emlékeztetnek a cinegefüz vesszőire, ez utóbbi faj azonban csak hetekkel később jelenik meg a piacon. Mivel a cinegefüz vesszője, az úgynevezett gyöngybarka értékesebb, a megjelenését megelőző időszakban néha megpróbálják a csigolyafüzt gyöngybarkaként értékesíteni. A gyüjtött csigolyafüz ára a kecskefüzénél valamivel magasabb (egy vessző minimum $10 \mathrm{Ft}$ ), azonban kereslete alacsonyabb.

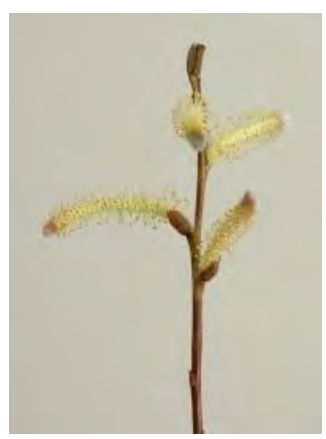

79. ábra: Virágzó $S$. purpurea

(fotó: Treer, 2004)

Ennek a barkának is sokféle alakjával találkoztam, például olyannal, amelyik a keskeny henger helyett egész vastag, nagy barkákat produkált. Az ilyen véleményem szerint már kevésbé értékes, mert ennek a fajnak az értéke éppen ez a különleges, filigrán barka a vékony vesszőkkel együtt. Vesszőjét korábban levágva kosárfonásra is használják. A faj barkás vesszői rendszerint február-március hónapokban kaphatók a piacon, valamivel később fakadnak virágzati rügyei, mint a kecskefüznek. Ugyanakkor a vékonyabb vesszők miatt sajnos hamarabb ki is szárad.

\section{Salix rosmarinifolia vesszők kínálata Magyarországon}

A gyöngybarka néven forgalmazott cinegefüz vesszők iránti kereslet a vizsgált években folyamatos, illetve egyre nagyobb volt, mivel a vékony, filigrán, apró, gömbölyü barkákkal berakódott vesszőket számtalan kompozícióban és virágcsokorban felhasználhatják a virágkötők. A 2010. év kivételével a gyüjtők arról számoltak be, hogy ez az egyetlen faj, melyből gyakorlatilag sosem maradt eladatlan árujuk, a teljes gyüjtött mennyiséget sikerült értékesíteniük. Az egyetlen probléma kései virágzása, amiért a többi barkafüzhöz képest csak hetekkel később tudják a piacra hozni, és korai Húsvét esetén csak rövid ideig van lehetőségük értékesíteni. 2010-ben is ez okozott problémát - az ünnep előtt három-négy héttel még sok virágkötő, kereskedő érdeklődött és vásárolt volna, ám a gyüjtők akkor még nem találtak kellően nyílott, vagy nyílasztható gyöngybarkát. Mikorra sikerült hozniuk a piacra, gyakorlatilag lezárult a kereslet időszaka. 2013-ban hasonlóan korai időpontra esett a Húsvét, és a szokatlan, késői nagy havazás tovább rontott a helyzeten. Csak két héttel az ünnep előtt hoztak gyöngybarkát a piacra, de az mind vevőre talált.

A rügypikkelyek az esetek többségében fennmaradnak a vesszőn, és a barkákat valamilyen mértékben (negyed vagy fele részben) borítják. Olyan köteggel is találkoztam, melyen a barkák egyharmad része látszott csak ki. Ez a variáció is dekoratív volt, így is megvásárolták. 
A gyöngybarkát is viszonylag nagy mennyiségben gyüjtik Somogy megyében, de korántsem hoznak onnan annyit, mint a kecske- vagy rekettyefüzből. Élőhelye is más, a gyüjtők szerint vízfolyás közelében található, de nem közvetlenül a parton, inkább a réten. A Balaton északi részéről, Tapolca és Sümeg környékéről változatos vesszőszínü, dekoratív példányokat hoztak (81. ábra). A gyüjtők is megfigyelték, hogy nem nő egy helyen a kecskefüzzel, amit ők leggyakrabban barkafának neveznek. Dabas környékén sokat gyüjtenek az úgynevezett turjánosok ${ }^{3}$ környékén. Egy gyüjtő, aki Somogy megyéből hozott árut, háromféle gyöngybarkát kínált - mind a három típus más alakú volt. Az egyik típusban kicsit bokros, elágazó vesszők voltak, teljesen berakódva nagyon apró, fél-egy mm átmérőjü barkákkal. Állító-

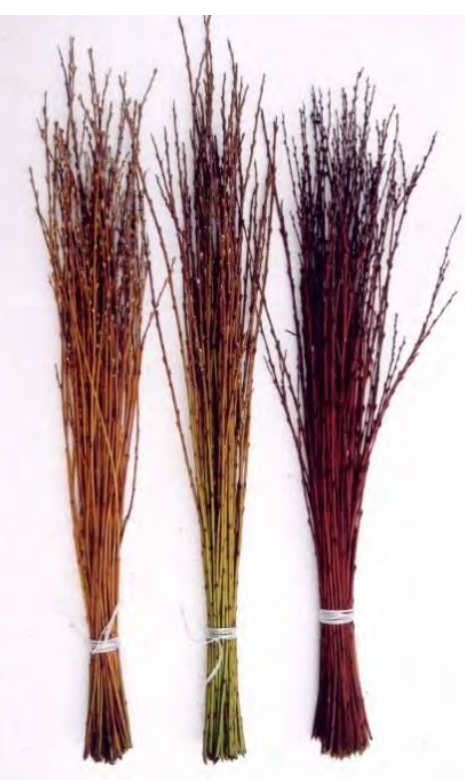

81. ábra: Tapolca környékén gyüjtött különböző vesszőszínü gyöngybarka kötegek (fotó: Treer, 2004)
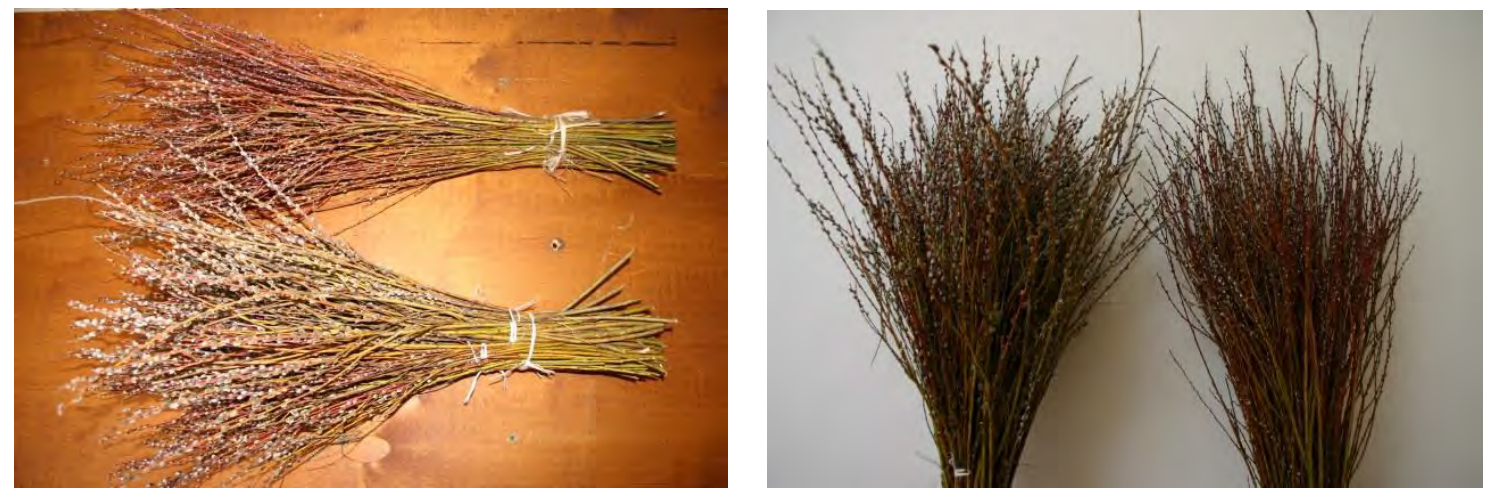

80. ábra: Nagyobb porzós és kisebb termős barkák $S$. rosmarinifolia vesszőkön (fotó: Treer, 2004)

lag ezeket köves, száraz területen gyüjtötte. A másik típusban egyenes, el nem ágazódó vesszők voltak nagyobb, enyhén hosszúkás-gömbölyded alakú barkákkal, vesszője hamvas bordó színű, és barkákkal tökéletesen berakódott volt. A harmadik típus a két előző közti átmenetet adta, de egyértelmủen elkülönült mind a kettőtől. Egy somogyi eladó gyűjtőhelyként említette még a Fonyód-Bélatelep vasúti szakasz melletti területet. Baranya megyéből is hoznak néhány köteget (80. ábra).

A gyöngybarka a korábban jellemzett fajoknál később virágzik, így barkái is közel egy hónapos késéssel jelennek meg a piacon az előzőekhez képest. Lehetett ugyan már február elején is gyöngybarkát kapni, de azok a vesszők díszítőértéküket tekintve igen gyengék voltak. Sokan próbálkoznak e faj „nyílasztásával” - gyakran már január hónapban megszedik a vesszőket, és szobában, fütőtest mellett, vízbe állítva, az ablak előtt fényen tartják addig, míg a rügypikkelyek

\footnotetext{
${ }^{3}$ Turjánosnak nevezik az alföldi síkságban az olyan bemélyedő területeket, melyeket gyakran tavasszal, hóolvadáskor elönt a víz, és csak nyárra száradnak ki.
} 
elkezdenek megpattanni. Legtöbbször sikertelen a kísérlet, a barkák többsége teljesen fedett marad. Az első sikeresen nyílasztott gyöngybarkával 2004 március elsején találkoztam, az eladó egy hónappal korábban gyüjtötte. A későbbi években a gyüjtők feladták a kísérletezést a nyílasztással, és csak akkor vágták le a vesszőket, mikor a tövön a barkák elkezdtek előbújni a rügypikkelyek alól.

A gyöngybarka vesszője a 2010. év kivételével magasabb áron kelt el, mint az előző fajoké. Egy szálat 10-60 Ft-ért kínálnak, a többi barkafüz 5-10 Ft-os árával szemben, a 10 szálas csomókból 3, 5, vagy 10 db-ot tesznek egy kötegbe. Egy 10-15 szálat tartalmazó, maroknyi méretű csomót 300-700 Ft-ért kínálnak eladásra, a nagyobb kötegek ára 1500-2500 Ft. A gyöngybarka kínálatban a kötegelt vesszők hosszúságának tekintetében nincsenek az előző fajokhoz hasonlóan sokszoros különbségek, az eladásra kínált vesszők hosszúsága 30-40 cm-től 80-90 cm-ig változhat. Többségében porzós példányokról származó veszőket kínáltak, de láttam porzós és termős barkájú vesszőket vegyesen tartalmazó köteget is. A barkák nemét csak fejlettebb állapotukban lehetett megállapítani. A termős virágok magháza ebben az állapotban zöld színü, bibéjük piros. A magház szabad szemmel is láthatóan szőrös.

\section{Egyéb barkás füzvesszők kínálata Magyarországon}

\section{Salix cinerea}

A magyar nevén rekettyefüzt a gyüjtők rekettyének hívják, szintén legtöbbet Somogy és Zala megyékből hoznak. Élőhelyeit jól ismerik az emberek, és szinte minden árus el tudta mondani, hogy csak víz közelében, vízparton nő, nem úgy, mint a szárazabb területeken is megtelepülő kecskefüz. Ez utóbbihoz hasonlóan óriási mennyiségben kínálják, de nem szaporítják. Barkái valamivel kisebbek a kecskefüz barkáinál, és alakjuk is eltérö, annál gömbölydedebb. A vesszők leggyakrabban sötét vagy világos barna színüek, teljes hosszukban molyhosak. A rügypikkelyek gyakran fennmaradók, sok esetben olyan árut értékesítenek, ahol a barkának csak kisebb hányada látszik, jó részét a rügypikkely fedi. Mivel kizárólag gyüjtésből származik, nincsenek olyan különlegesen hosszú vesszők, mint amilyen kecskefüzből nevelhető. A bokros ágakat általában egy szálasra feldarabolják, és a hasonló méretűeket kötegelik együtt. Ennek következtében egészen rövid, 25-30 cm-es vesszőket is értékesítenek, melyeket koszorúkhoz használnak a virágkötők. A rekettyefüz ára közel azonos az ugyanolyan méretü kecskefüz vesszőkével. Különösen hosszú vesszői azonban nincsenek, ezért nem lehet olyan magas bevételt elérni vele, mint esetleg néhány hosszabb, akár 3 m körüli $S$. caprea vesszővel, ellenben az egész rövid rekettyefüz vesszőket akár 2-3 Ft-ért adják.

\section{Salix viminalis}


A kosárfonó füz több mint egy hónappal a nagybarkájú füzek után jelent meg a piacon, a gyöngybarkával egy időben, de ezt a fajt nem nyílasztották a kétezres évek elején sem. Barkája a csigolyafüzéhez hasonlóan keskeny, hosszúkás. A lombfakadás azonban a virágzással szinte egy időben kezdődik, minden barka tövében egy apró fellevél zöldellt, ami a vágott vessző díszítőértékét nagy mértékben csökkentette. Rövid ideig tartott az az állapot, amikor már szedhető volt ez a faj, de még nem fakadtak ki rajta a levelek. Általában egy hét áll a gyüjtők rendelkezésére, hogy megszedjék az árut. A 2004. évben ezen a héten végig szakadt az eső, így a barkák megáztak. Hiába száradtak utána meg, a murvapikkelyeken lévő finom szőröket a víz eláztatta, összeborzolta, és így az összes barka csökkent értékü maradt. Kivétel nélkül minden árusnál ilyen barkákat találtam, melyeket nehezen tudtak csak értékesíteni.

\section{Salix fajok barkás vesszőinek felhasználása és termesztése}

A hazai különleges (fás szárú) vágott virág termesztők esetében az egyik legnagyobb nehézségnek a specializálódás hiányát látom. Sok más tevékenység mellett a különleges vágott virágok termesztését, az ültetvények ápolását-gondozását könnyen elhanyagolják, ami az áru minőségének leromlásához vezet. A szolnoki csigolyafüz ültetvény esetében például egy erős, fiatalító visszavágást követően az ültetvényt újra használatba lehetne vonni. Az egeraljai, inkább erdészeti csemetekert sem volt felkészülve a különleges vágott virágok betakarítására, tárolására, az értékesítés megszervezésére. Legsikeresebbnek a móri kertészet bizonyult, ahol nagyobb hangsúlyt fektettek az minőségi áru osztályozására, megfelelő kiszerelésére, tárolására, és a különleges vágott virágokat sikeresen értékesítik a Flora Hungaria nagybani virágpiacon.

A virágpiacon a gyüjtött növényanyagot tekintve szinte kizárólag porzós barkájú füz veszszőket kínáltak eladásra, ennek oka, hogy a rügypikkely leválását követően, a füzér virágzati tengelyének enyhe megnyúlásakor a kétféle virágzati kezdemény közül a porzós mindig szebb, nagyobb. Ez megfelel FRANK (2008) megállapításának, aki a törékeny füzről ír, de a többi füzre is igaz lehet, hogy a hímbarkában több virág található, mint a női füzérekben. Szintén erről a füzről írja, hogy a természetes populációkban a hím- és a nőivarú egyedek aránya 4:1. Hasonló lehet ez az arány a barkafüzek esetén is, ezért is adódik az, hogy a gyüjtők sokkal több porzós egyeddel találkoznak, mint termőssel.

\section{Barkás vesszők a hazai piacon}

A S. caprea fajból már vannak sikeres fajták, ezek termesztésével hazánkban érdemes lenne foglalkozni. Nem kifejezetten vágó barka, de itt szeretném megemlíteni, hogy az irodalomban sokféleképpen leírt 'Pendula' és 'Kilmarnock' nevü fajtákat illetően a következőket tapasztaltam. Két különböző fajtaként forgalmazzák, mindkettő porzós klón, a 'Pendula' barkái kisebbek, ke- 
vésbé ezüstösek. Éppen ezért Ny-Európában a 'Kilmarnock' fajta elterjedt, hazánkban még inkább a 'Pendula' (vagy ezen a néven forgalmazott 'Kilmarnock') alkotja a kínálatot. Várhatóan nálunk is a 'Kilmarnock' veszi majd át a 'Pendula' helyét.

Újdonságként bevezethető a $\boldsymbol{S}$. purpurea barkás vesszőinek felhasználása, külföldön érdekességként bizonyára lenne iránta kereslet. A nagybani piacon látott vesszők alapján elmondható, hogy a hazai populációkból különösen dekoratív vesszőszínű és formájú fajták szelektálhatók.

A gyöngybarka (S. rosmarinifolia) minden bizonnyal óriási siker lenne, hazai állományaiból számtalan dekoratív fajtát lehetne szelektálni. Ez a faj külföldön nem ismert. Hollandiában és Németországban, nemzetközi dísznövény kiállításokon járva tapasztaltam, hogy a kúszó $S$. repens fajnak számos fajtáját oltják fel magas törzsre, és így apró barkájú, mutatós, kicsi szomorúfüzeket kapnak. Ezeknek a kúszó (csüngő) formáknak azonban seszínű, szürkés-barna a veszszője, ezért sem lennének versenyképesek a barkás vesszők piacán a magyar cinegefüzzel.

A kecskefüz fajták esetében a nemesítők célja minél nagyobb (és ezüstösebb, színesebb, stb.) barka előállítása. Ez a folyamat hasonlít ahhoz, ahogyan sok vágott virág, illetve virágos cserepes dísznövény virágméretét igyekeztek nemesítéssel mindjobban megnövelni. Egy idő után pedig új irányzat alakult ki, amely mindenből a legapróbbat próbálta kihozni, így lettek népszerüek a különböző „Mini”'-k (pl mini rózsák, mini gerbera, stb.). Ezeknek lehetne megfelelője a barkás vesszők között a gyöngybarka.

A S. cinerea felhasználásáról egyetlen virágkötőknek szóló irodalomban találtam utalást [KLINCSEK, 1990]. SiMON (2000) védendőnek nevezi, ennek ellenére viszonylag nagy mennyiségben láttam a piacon. Maga a faj minden bizonnyal védendő, bár a kecskefüzzel (és más füzekkel is) kereszteződött hibridjei nagy számban fordulnak elő az országban. Mint a természetből begyüjtött faj, valószínüleg vissza fog szorulni, helyét a termesztett kecskefüz fajták veszik át várhatóan.

A S. viminalis faj is egy lehetőség a barkás vesszők választékában, a piacon már jelen van. Előnye, hogy később virágzik, tehát nem kell korán megszedni, ugyanakkor a barka díszítőértéke nem különösebben jelentős, a hamarosan bekövetkező lombfakadás pedig hátránya. Számtalan hibridje fordul elő az országban, a kifejezetten kosárfonásra telepített ültetvényekből sok beporozza az alapfajt, és ennek következtében dekoratív vesszőszínek alakulhatnak ki. 


\section{M6. Gibberellinsav alkalmazása egyéb dísznövények hajtatásakor}

MuROMCEV és AGNYISZTYIKOVA (1976) megállapították, hogy a gibberellin hatására a virágkocsányok gyakran megnyúlnak, a virágok megnövekednek, a virágzatok nagyobbak lesznek. A hatás nagymértékben függ a kezelés idejétől. A virágkezdemény képződésének idején végzett kezelés késleltetheti a virágzást és megváltoztathatja a virágok felépítését. Ha azonban a kezelés a bimbózás időszakában történik, nagyobb virágok képződhetnek. ABONYI (1998) diplomamunkájában ír a gibberellin növekedést serkentő, valamint a virágok mennyiségét és minőségét javító hatásáról. Kála esetében 25, illetve $50 \mathrm{mg} / 1$ töménységü $\mathrm{GA}_{3}$-ba áztatta a gumókat 10 percig. Az amarillisznél is sikeresen alkalmazta a gibberellinsavat 2000 mg/l koncentrációban 24 órán keresztül. CORR és WIDMER (1991) a gibberellin megnyúlásos növekedésre kifejtett hatását bizonyították, amikor Zantedeschia fajok rizómájának törpítő kezelését gibberellin kezeléssel kombinálták. A paclobutrazol hatóanyagú Bonzi növekedésgátló hatását a gibberellin teljes mértékben ellensúlyozta [CORR és WIDMER, 1991]. A gibberellin egyes növényekben elért virágzást előidéző hatásáról ír HENNY (1983). Aglaonema commutatum 'Treubii' fajta lombját permetezve 100, 200, illetve 400 ppm-es töménységben a virágzás megindult, míg a kezeletlen növények nem virágoztak. Dieffenbachia maculata 'Perfection' fajtát kezelve 250, 500, illetve 1000 ppm-es $\mathrm{GA}_{3}$-al, lombpermetezés formájában a kezelt növények virágoztak, a virágszám arányosan nőtt a szer koncentrációjával [HENNY, 1980]. HARBAUGH és WILFRET (1979) a gibberellin virágzásserkentő hatását vizsgálták Caladium hortulanumon. A gumókat 16 óráig 250 ppm-es $\mathrm{GA}_{3}$ oldatban áztatva a kezelés a növényenkénti virágzó hajtásszámot és a hajtásonkénti virágszámot is növelte. Bose et al. (1980) a Hippeastrum hybridum 'Fire Dance' fajtát 10, 100 és $1000 \mathrm{mg} / 1 \mathrm{GA}_{3}$ oldattal kezelték. Az egyik kísérletben 24 óráig áztatták a hagymákat ültetés előtt, a másikban a növényeket két-három lombleveles korban permetezték a szerrel, majd ezt 30 nap múlva megismételték. Az áztatás minden koncentrációban egynél több virágszárat eredményezett, a permetezésnek nem volt ilyen hatása. A virágszár hosszát mindkét módszer növelte magas koncentrációban alkalmazva. A legtöbb virágot a $100 \mathrm{mg} / \mathrm{l}$-es áztatás, illetve a 100 és $1000 \mathrm{mg} / \mathrm{l}$-es permetezés eredményezte. A virágok méretét mindkét kijuttatási mód növelte, legnagyobb virágátmérőt az 1000 mg/l-es áztatással lehetett elérni. CORR és WIDMER (1987) kála rizómákat kezeltek 50, 100, 500 és 1000 ppm-es $\mathrm{GA}_{3}$-al. Permetezéskor a szer csak gyengén szívódott fel, az áztatási koncentrációk közül az 500 ppm (10 perces áztatás) bizonyult leghatásosabbnak a virághozam növekedése szempontjából. A rizómánkénti hajtások száma, valamint a hajtásonkénti virágszám is növekedett. FUNNELL és MACKAY (1992) kísérletükben a Zantedeschia 'Galaxy' fajtájának rizómáit 25, 50, és 100 ppm-es GA3 oldatban áztatták 10 másodpercen, 1, illetve 30 percen keresztül. A virágok megjelenésének idejét a kezelések nem befolyásolták, a virághozam azonban 
megemelkedett. Leghatásosabbnak a 25 ppm-es kezelés bizonyult. REISER és LANGHANS (1993) különböző kála fajtákon vizsgálták a gibberellin kezelés hatását. A rizómákat ültetés elött 10 percre $\mathrm{GA}_{3}$ 100, illetve 500 ppm-es oldatába mártották. A virághozam minden esetben emelkedett, a magasabb hormonkoncentráció hatására nagyobb mértékben. DENNIS et al. (1994) szintén kála rizómákon végzett kezelésekkel vizsgálták a gibberellinsav virághozamra, illetve minőségre gyakorolt hatását. A rizómákat egy percre $\mathrm{GA}_{3} 25$, valamint 50 ppm-es oldatába mártották, itt is az előbbi koncentráció bizonyult hatásosabbnak. CAROW (1978) a Lilium longiflorum esetében alkalmazott sikeresen gibberellinsavat 500 és 1000 ppm koncentrációban. 


\section{M7. Glikolokkal tartósítható fás szárú zárvatermők}

Az alábbi felsorolás azokat a fás szárú, nyitvatermő növénytaxonokat tartalmazza KoCH (1995) kézikönyve alapján, melyekkel sikeresen végeztek tartósítási kísérletet glikolok alkalmazásával. A tartósítás módját a taxon neve melletti F (felszívatás), vagy M (merítés) betủvel jelöltem. Amennyiben mindkét módszer alkalmazható, a javasolt eljárás betüjelét vastagon kiemeltem.

Abelia (örökzöld fajok) $\mathrm{F}$
Abelia $\mathrm{F}$
Abeliophyllum $\mathrm{F}$
Alnus (számos faj) $\mathrm{F}$
Amelanchier $\mathrm{F}$
Andromeda $\mathrm{F}$
Arctostaphylos manzanita $\mathrm{F}$
Aronia $\mathrm{F}$
Aruncus $\mathrm{F}$
Atriplex $\mathrm{F}$
Betula $\mathrm{F}$
Bruckenthalia $\mathrm{F}$
Bumelia $\mathrm{F}$
Buxus (tartósítása nagyon
nehéz) $\mathrm{F}$
Calluna $\mathrm{F}$
Canstanopsis chrysophylla $\mathrm{F}$
Carpinus $\mathrm{F}$
Cassiope $\mathrm{F}$
Castanea pumila $\mathrm{F}$
Cephalanthus $\mathrm{F}$
Cercidiphyllum $\mathrm{F}$
Cercocarpus betuloides; $\mathrm{C}$.
breviflorus $\mathrm{F}$
Chaenomeles $\mathrm{F}$
Chamaedaphne $\mathrm{F}$
Chionanthus $\mathrm{F}$
Comptonia $\mathrm{F}$
Corylopsis $\mathrm{F}$
Crataegus $\mathrm{F}$
Cydonia $\mathrm{F}$
Cytisus scoparius $\mathrm{F}$
Daphne $\mathrm{F}$
Dirca $\mathrm{F}$
Elaeagnus angustifolia $\mathrm{F}$
Enkianthus $\mathrm{F}$
Erica $\mathrm{F}$

Eucalyptus globulus; E. coccifera; E. cordata; E. gunii; E. pulvulenta $\mathbf{F}, \mathrm{M}$ (Hajlamos a könnyezésre ha túl sok glikolt vett fel a növény.)

Eucommia $\mathrm{F}$

Euptelea $\mathrm{F}$

Exochorda $\mathrm{F}$

Fagus F

Fontanesia $\mathrm{F}$

Forsythia $\mathrm{F}$

Gaultheria $\mathrm{F}$

Gaylussacia $\mathrm{F}$

Hamamelis $\mathrm{F}$

Hibiscus $\mathrm{F}$

Kalmia $\mathrm{F}$

Kerria $\mathrm{F}$

Ledum $\mathrm{F}$

Leiophyllum $\mathrm{F}$

Leitneria $\mathrm{F}$

Leucothoe fontianesiana $\mathrm{F}$

Liquidambar $\mathrm{F}$

Liriodendron tulipifera $\mathbf{M}, \mathbf{F}$

(Csak a lombos ágak tartósíthatók. A virágok nem reagálnak jól a bennük lévő víztartalom glikolokkal történő helyettesítésére.)

Lonicera (kislevelü fajok) $\mathrm{F}$ Lyonia $\mathrm{F}$

Magnolia acuminata; $M$.

fraseri; $M$. grandiflora; $M$.

pyramidata; $M$. tripetala; $M$.

virginiana $\mathbf{M}, \mathrm{F}$ (Csak a lombos ágak tartósíthatók. A virágok nem reagálnak jól a bennük lévő víztartalom glikolokkal történő helyettesítésére.)

Mahonia bealii $\mathrm{F}$

Malus F

Myrica $\mathrm{F}$

Oxydendrum $\mathrm{F}$

Parrotia $\mathrm{F}$

Parrotiopsis $\mathrm{F}$

Physocarpus $\mathrm{F}$

Pieris F

Platanus F

Populus tremuloides; $P$.

deltoides; P. deltoides var.

occidentalis; P. angustifolia $\mathrm{F}$ (A felesleges glikol mennyiség könnyen kiválik a növényeken.)

Potentilla $\mathrm{F}$

Prunus laurocerasus $\mathrm{F}$

Pyrus calleryana 'Bradford' F

Quercus dumosa; $Q$.

gambelii; Q. turbinella; F, M

Rhododendron $\mathrm{F}$

Rhodotypos $\mathrm{F}$

Smilax F

Sorbaria F

Sorbus alnifolia; $S$. hostii $\mathrm{F}$

Spiraea F

Staphylea F

Symplocos F

Tilia $\mathrm{F}$

Vaccinium $\mathrm{F}$

Yucca $\mathrm{F}$

Zenobia $\mathrm{F}$ 


\section{M8. Salix taxonok mikrotechnikai módszerekkel történő vizsgálata és ábrázolása}

A virágzatokból egy-egy virágot kiszedtem, ezeket elsősorban sztereomikroszkóp (OLYMPUS SZH10 Research Stereo) alatt vizsgáltam. Az egyes virágok tövében található murvapikkelyek megfigyelése alapvető a barkás vessző díszítőértékének jellemzéséhez, mivel a barka színének kialakításában szerepük elsődleges a rajtuk elhelyezkedő szőrökkel együtt. A Salix caprea CA1 klón különösen érdekes színü murvapikkelyéből metszetet készítettem, valamint szőreit is megfigyeltem fénymikroszkóp alatt. Borostyánfejes mikrotrómmal vessző- és levélmetszetet is készítettem. A vizsgált növényekről a következő rajzokat készítettem.

I. Poszter (155. o.): A leveles hajtást egy 2003 tavaszán fásdugvánnyal általam szaporított példány után rajzoltam. A dugványból kihajtott vesszőt nem vágtam vissza, a lerajzolt rövidebb hajtás azon fejlődött. Mellette méretarányosan ábrázoltam egy barkákkal szépen berakódott elágazódó vesszőt. Feljebb egy-egy rajzon egy termős és egy porzós virágot ábrázoltam tövükön a murvapikkellyel. A termős virág magháza nyélen fejlődik, az egész szőrös. A $S$. caprea CA1 klón virágzatát szétszedtem, és külön is vizsgáltam a fekete murvapikkelyt. Metszetet készítettem belöle, ami miniatür mérete miatt nem volt egyszerü. Elöször 21-es méretre állítottam be, de az a metszet túl vastag lett, végül 17-est sikerült készítenem. Ezt rajzoltam le a porzós virág mellé. A murvapikkely fonáka látható a rajta lévő erekkel. Mellette a fellevélen található hengeres, kihegyesedő csúcsú, egysejtü szőröket ábrázoltam.

II. Poszter (156. o.): A leveles hajtást szintén egy általam szaporított növény után rajzoltam. 2004 tavaszán dugványoztam, 2-4 ilyen méretü hajtás fejlődött dugványonként. Mellette a barkás vesszőt láthatjuk. Feljebb egy kisebb rajzon ábrázoltam azt a vesszőt, melynek aljából a metszetet készítettem. A rajzon bejelöltem, hogy a metszet két, rügypikkellyel még teljesen fedett, zárt rügy közti szártagból készült. A keresztmetszeti rajzon elkülöníthető a periderma (p) és a háncsrész (h), melyben kisebb csoportokat alkot a szklerifikálódott elsődleges háncs (háncsrostok). A bőrszövet alatt még jól látszik a lemezes kollenchima, melynek megvastagodott sejtfala a fénymikroszkópban nézve ezüstösen csillog. A kambium (k) sejtsorától befelé következnek a fa elemek (f), majd jól látható a bélszövet (b) nagyobb, lazábban elhelyezkedő sejtjeivel.

III. Poszter (157. o.): Baloldalt alul egy hím barkákkal berakódott $S$. cinerea vessző részletét ábrázoltam, mellé egyetlen porzós virágot. Feljebb egy virágzó termős füzért rajzoltam le. Amikor ezt gyüjtöttem, a porzós barkák már sárgállottak a növényeken. A füzér mellé egy belőle kipreparált rövid kocsányú, hosszú nyakú, szőrös termős virágot rajzoltam. A murvapikkely a termőrészekhez késpest viszonylag apró. 
A középen ábrázolt cinegefüz barkás vesszöjét 2004 tavaszán dugványoztam konténerbe, július közepére az eredetileg A/3-as poszteren ábrázolt méretủ hajtások fejlődtek rajta. A ledugott vessző csúcsa elszáradt, legfelül egy apró (elszáradt) barka maradt rajta tavaszról. Mellette egy elágazódó barkás vesszőt ábrázoltam. Ezeken a barkákon fennmaradtak a barna rügypikkelyek, de véleményem szerint nem rontottak a vessző díszítöértékén. A barkák közt apró, zárt, nagyrészt vegetatív rügyek láthatók a vesszőn.

Végül szerettem volna a Salix nemzetség valamely fajának leveléből is metszetet készíteni 2004 április végén a Budai Arborétumból egy nőivarú mandulalevelü füz cserjéről szedtem egy frissen kihajtott levelet, ezt metszettem. A keresztmetszeti rajz a foér helyén hiányosnak tünik, ez valószínűleg azért lett ilyen, mert a levél még nagyon zsenge volt, és a szövetek könnyen roncsolódtak. A levél széle felé a keresztmetszeti rajzon jól elkülöníthetők a pallisad parenchima sejtek. 
DOI 10.14267/phd.2014004

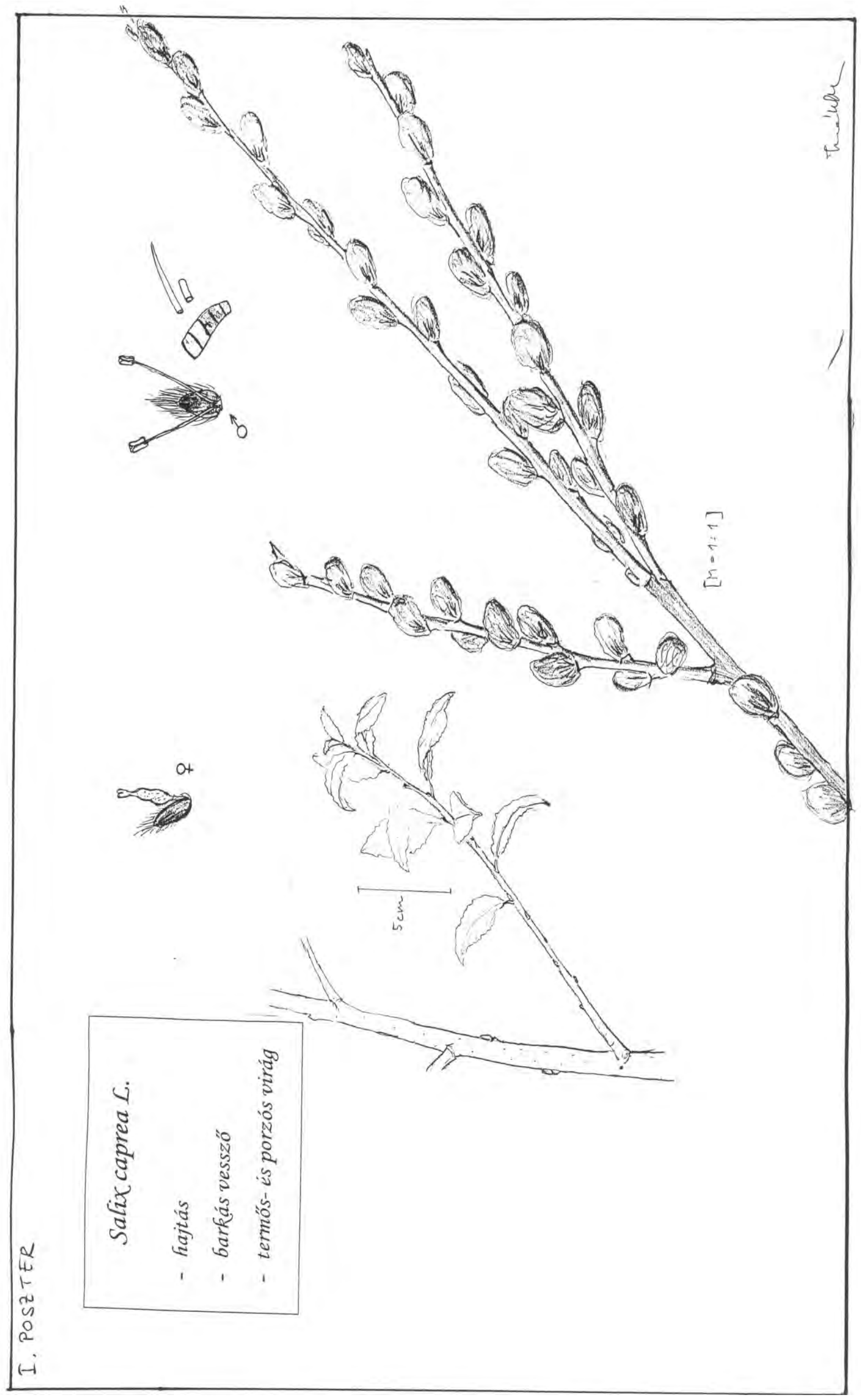




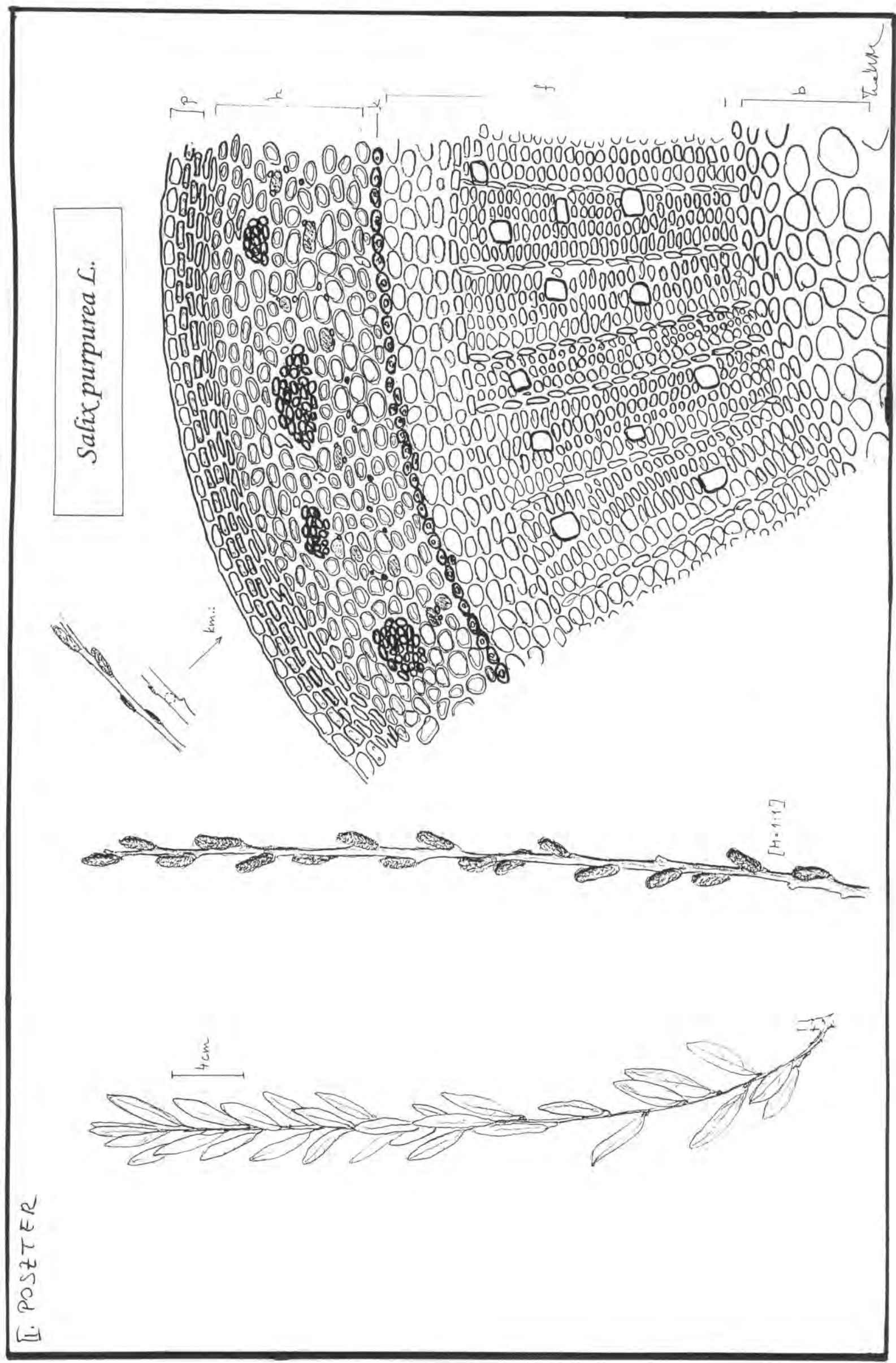




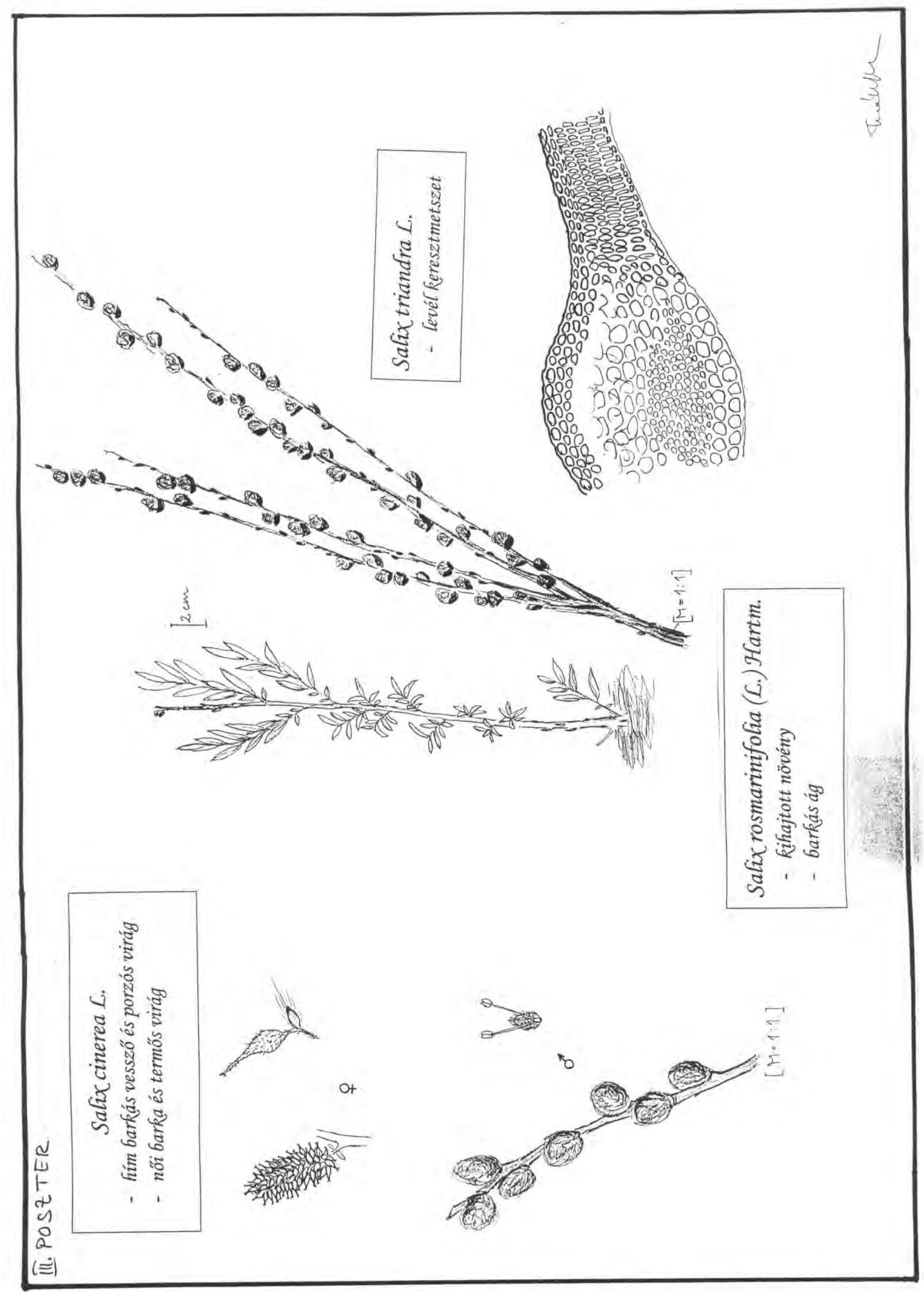




\section{M9. A gyökereztető szerek, kezelések, és a dugványozás időpontjának hatása a dugványok gyökeresedésére - jegyzőkönyv szöveges kivonata}

\section{Salix caprea gyökereztetése}

\section{CA_H: melegtalp nélkül}

A Kelpak ${ }^{\circledR}$-kal való fél órás felszívatás eredményeként a novemberi dugványok esetében egy hét után 10-ből 2 dugvány alja vastagodott meg. Két hét után a kontroll dugványokhoz hasonló, vagy az azokon lévőknél még kisebb, apró kalluszcsomók jelentek meg a dugványokon. Három héttel a kezelés után 50-ből 22 dugványon 2-5 cm hosszú hajtások fejlődtek, melyeken a levelek még nem terültek ki. Nyolcból öt dugványon fejlödött több (3-6 db) 5-10 mm hosszú gyökér. A kezelést követően nyolc héttel az 50 dugványból 39 kihajtott, hasonlóan a kontroll dugványokhoz. Nyolc dugványból 2 nem hajtott ki, de ezek is gyökeresedtek; illetve az egyiken csak kalluszcsomók jelentek meg. A kihajtott dugványok alján az epidermiszt áttörték a kalluszcsomók, és 1-3 cm hosszú gyökerek fejlődtek. A decemberben szedett és dugványozott, Kelpak $^{\circledR}$-kal fél órán keresztül felszívatott dugványok több mint három héten keresztül nyugalomban maradtak, nem hajtottak, és gyökeresedésnek sem láttam rajtuk nyomát. Nyolcból három dugvány talpától felfelé minimális halvány barnulást észleltem. Öt héttel a dugványozást követően hajtottak ki (50-ből 44 dugvány) a Kelpak ${ }^{\circledR}$-kal fél óráig kezelt dugványok a kontroll növényekhez hasonló 5-20 mm-es hajtásokkal. A megindult fejlődés következtében egy barka bújt elő a virágzati rügyet fedő rügypikkely takarásából. Nyolcból hét dugványon figyeltem meg kalluszképződést, elsősorban a dugványok alsó fél-egy centiméteres szakaszán, ahol a kambiumból képződő kallusztömeg függőleges irányban felhasította a héjkérget, helyenként 1-2 mm hosz-

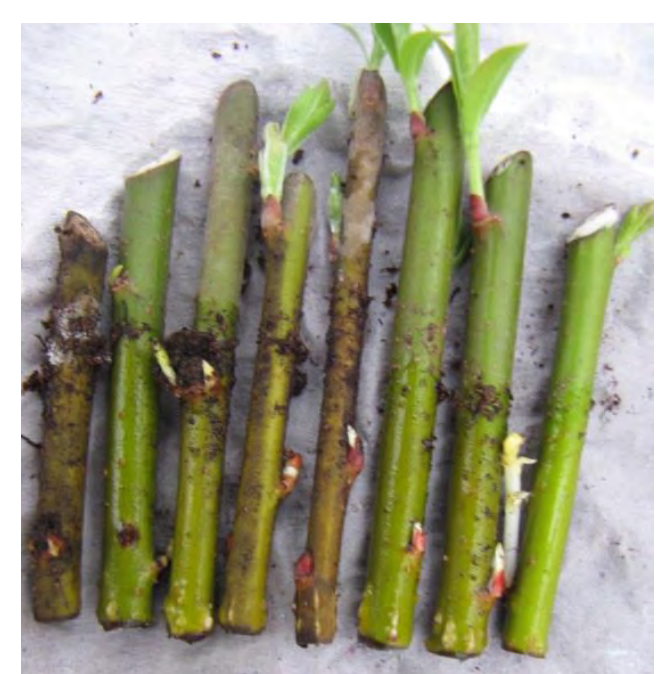

82. ábra: Decemberben szedett és dugványozott $S$. caprea dugványok (melegtalp nélkül, Ke1/2 kezeléssel) 5 héttel a dugványozást követően (fotó: Treerné, 2010) szan, egybefüggőn (82. ábra).

A januárban szedett és dugványozott dugványoknál a kezelést követően két héttel 50 dugványból 36 elkezdett hajtani, a kontroll dugványokhoz képest rövidebb hajtásokkal. Tízből három dugvány alsó fél centiméteres szakaszán a kalluszképződés következtében felrepedt a héj. Hét másik dugványnak majdnem teljes hosszában kalluszcsomók fejlődtek, apróbbak és kevesebb a kontroll dugványokhoz képest. Három hét elteltével öt dugvány közül kettőn 3-4 db, 2-3 mm hosszú gyökér fejlődött, két dugványon nagyobb kalluszcsomók törték át az epidermiszt. Négy héttel a januári dugványok kezelését 
követően nyolcból nyolc dugvány gyökeresedett; alsó fél centiméteres szakaszukon öt vagy még több 4-5 mm hosszú gyökér fejlödött.

A Kelpak ${ }^{\circledR}$-kal 8 órán keresztül felszívatott dugványok közül a novemberben szedett és dugványozott dugványokon az első héten még semmi szemmel látható változás nem történt. A második hét után 50-ből 14 dugvány hajtásrügyei fakadtak meg, a hajtáskezdemények $5 \mathrm{~mm}$ hosszúak voltak. Nyolcból négy dugvány alul bunkószerüen megvastagodott, több helyen felhasadt a héjkéreg, kilátszott a fehérlő kallusz. A másik négy dugványon nem tapasztaltam változást. Három héttel a kezelés után 50-böl 38 dugvány hajtott, és a kezelések közül ez hozta a legnagyobb, $5 \mathrm{~cm}$ hosszú hajtásokat, melyen a levelek is kiterültek. A dugványok nem barnultak, de alul még mindig csak domborodó kalluszcsomók és a függőlegesen felrepedt kérget áttörő kallusz jelent meg, gyökerek nem fejlödtek. Nyolc héttel a kezelést követően az 50 dugványból 49 kihajtott, akár 5-8 cm hosszú, nagylevelü hajtásokkal. Nyolc dugványból kettőn 6-7 db, 1-3 cm hosszú gyökér fejlődött, hat dugvány alján kalluszcsomók domborították fel az epidermiszt, de még nem törtek át. A Kelpak ${ }^{\circledR}$-kal 8 órán keresztül felszívatott, decemberben szedett dugványokból a kezelést követően három héttel 29 dugványon megpattantak a rügypikkelyek, és alóluk 1-2 mm-es hajtáskezdemények bújtak elő. A dugványok alján jelentős változást nem tapasztaltam, helyenként félhold alakú halványbarna elszíneződés, szöveti elhalás volt felfedezhető a dugványok talpánál. A decemberi kezelések után öt héttel 50-böl 46 dugvány kihajtott, 1-3 cm hosszú hajtásokkal, kicsit erősebben, mint a kontroll esetében tapasztaltam. Nyolcból nyolc dugvány talp felőli $5 \mathrm{~mm}$-es részén $1 \mathrm{~mm}$ hosszan az epidermisz felrepedt, a szár belsejében képződő kallusz láthatóvá vált. A 8 órás Kelpak ${ }^{\circledR}$ kezelésben részesített, januárban szedett és 50 dugványból a kezelést követően két héttel 42 dugványon megpattantak a hajtásrügyek. Tízből négy dugvány alsó 5-10 mm-es szakaszán repedt föl az epidermisz a kalluszburjánzás eredményeképpen, a többi hat dugványnak elsősorban az alsó részén, és feljebb csak elvétve jelent meg egyegy pontszerü kalluszcsomó. Három hét elteltével nyolcból négy dugványon sok $(5 \leq$ db/dugvány), 1-2 mm nagyságú gyökér fejlődött, másik négy dugványon apró kalluszcsomók törték át az epidermiszt. Négy hét elteltével minden dugványon átlagosan $6 \mathrm{~cm}$ hosszú hajtások fejlődtek kibomlott levelekkel. Öt dugványból kettőn sok ( $5 \leq \mathrm{db}$ /dugvány), 1-3 cm hosszú gyökér fejlődött, a másik három dugványon kalluszcsomók törték át az epidermiszt.

A NES oldattal kezelt $S$. caprea dugványok melegtalp nélküli gyökereztetésekor csak a novemberi dugványokon fejlődtek $1 \mathrm{~mm}$ körüli gyökérkezdemények az erősen megvastagodott dugványokból (2 héttel a kezelést követően), a többi időpontban szedett dugványokon a kezdeti intenzív kalluszosodást követően megindult a dugványok nagy részének barnulása, pusztulása. A decemberben szedett 47 dugvány közül a bonitálás időpontjában, azaz 13 héttel a kezelést követően tíz dugványon voltak gyökerek vagy kalluszcsomók, a többi nem élt. 


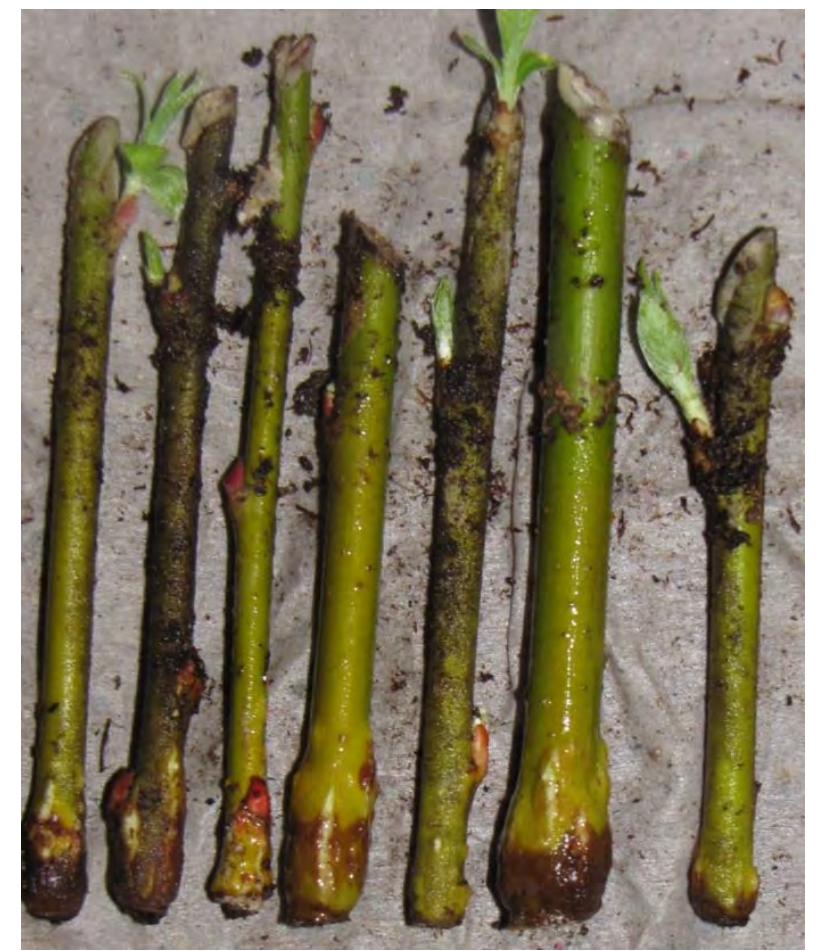

83. ábra: NES oldattal kezelt, decemberben szedett S. caprea dugványok kalluszképzése melegtalp nélkül, 5 héttel a dugványozást követően (fotó: Treerné, 2010)

A Naftil-ecetsavval alkoholos oldat formájában kezelt novemberi dugványokon már a kezelést követő első héten a teljes szaporító közegben lévő részen megjelentek a kalluszcsomók, melyek belülről feszítették az epidermiszt, illetve kezdték azt áttörni. A kezelést követő második héten 50-ből 26 dugvány kihajtott. A dugványok alsó részükön erősen megvastagodtak, az epidermisz több helyen hosszában felrepedt, ezeken a hasadékokon tört át a differenciálatlan kalluszszövet. A dugványokon feljebb kalluszcsomók törték át az epidermiszt. Három héttel a kezelést követően 26 dugvány $3 \mathrm{~cm}$-es hajtásokat hozott, melyeken a levélkék elkezdtek kiterülni. A dugványok alsó része erősen megvastagodott. Nyolcból három dugvány alján a hosszában felrepedt epidermiszen keresztül differenciálatlan kallusztömeg látszott, öt dugvány esetében szintén felhasadt az epidermisz, de a megvastagodott talpi rész már megbarnult, elhalt. A kezelés után nyolc héttel a kihajtott 26 dugványból 11 élt, rajtuk 3-6 cm-es hajtások zöldelltek, a többi megbarnult, elszáradt. Nyolcból nyolc dugvány alja bunkószerüen megvastagodott, megbarnult, a dugványok elpusztultak. A S. caprea decemberben szedett és NES oldattal kezelt dugványai közül a kezelést követően három héttel nyolcból két dugvány alján törték át az epidermiszt apró kalluszcsomók, két vékonyabb dugvány alsó része megvastagodott, a maradék négy dugványnál semmilyen változást nem észleltem. Öt hét elteltével 50-ből 35 dugványon pattantak meg a rügypikkelyek, és a virágzati rügyekből feketedő murvapikkelyü barkák; a hajtásrügyekből 5-10 mm-es hajtáskezdemények fejlődtek. (Öt héttel a decemberi dugványozást követően a kezelési módok közül ez eredményezte a leggyengébb hajtásnövekedést, a többi kezelt dugvány mind jobban hajtott.) Nyolcból hét dugvány esetében az alsó $2 \mathrm{~cm}$-es szakasz erősen, bunkószerüen megduzzadt, és hosszanti irányban felhasadt, a réseken keresztül kilátszott a differenciálatlan kallusztömeg (83. ábra). A januárban szedett és dugványozott dugványokon a kezeléseket követően két hét elteltével a rügypikkelyek alól fejlődésnek indultak a hajtások. Tízből három dugványon semmi sem változott. A másik hét dugvány alsó két centiméteres része szélesen duzzadt, a kéreg hosszirányban felhasadt, kilátszott a fehér kallusztömeg. Három hét elteltével 24 dugvány hajtott ki. Ötből öt dugvány alja rendkívül erősen megvastagodott, rajtuk a héj hosszirányban felrepedt, de gyökerek nem fejlődtek, a dugványok alja kezdett barnulni. 
Négy hét elteltével már csak 16 dugványon voltak élő, 3-5 cm-es hajtások, a többi elszáradt, elpusztult. Ötből öt dugvány alja erősen, bunkószerüen megvastagodott, megbarnult, elhalt.

A naftil-ecetsavval por formájában kezelt novemberi dugványok közül tízből nyolc alján már az első hét után megjelentek a kalluszcsomók. Két hét elteltével 50 dugványból nyolc kihajtott. A dugványok alja megvastagodott, hosszirányban felrepedt a héj, és megjelent a kallusz, gyökér nem fejlődött. A kezelések után három héttel már 21 dugvány hajtott, 2-5 cm-es hajtásokkal, kiterülő levelekkel. A dugványok alsó fél centiméteres szakaszán a hosszában felrepedt héjkéregből kalluszcsomók törtek elő egymás alatt, az egyik dugványnál egy gyökér is fejlődött. A kezeléseket követően nyolc héttel 50-ből 34 dugvány hajtott ki, 3-6 cm-es hajtásaikon a levelek teljesen kiterültek. Nyolcból öt dugvány alján dugványonként 8-10 db, néhol elágazódó gyökér fejlödött. A gyökerek csak a dugványok alsó 1-2 cm-es szakaszán fejlődtek. Két dugvány alján kalluszcsomók és $1 \mathrm{~mm}$-es gyökérkezdemények fejlődtek. A nyolcadik dugvány elpusztult. A S. caprea decemberben szedett és NES porral kezelt dugványain három héttel a kezelést követően semmilyen jelentős változást nem tapasztaltam. Nem hajtottak, és gyökeresedésnek sem volt nyoma, néhány dugvány talpa halványan megbarnult. Öt héttel a kezeléseket követően 50ből 43 dugványon 1-1,5(-2) cm-es hajtások fejlődtek. Nyolcból öt dugvány alja erősen megvastagodott, rajta hosszirányban felhasadt a héjkéreg, a differenciálatlan kallusztömeg kitüremkedett. A januári dugványokon a kezeléseket követően két hét elteltével megkezdődött a hajtásrügyek fakadása, 1-2 mm-es hajtáskezdemények indultak fejlődésnek. Tízből hét dugvány alja bunkószerüen megvastagodott, rajtuk felhasadt a héjkéreg, és jól látszott a kallusztömeg. Hat dugvány teljes hosszán apró kalluszcsomók jelentek meg. Három hét elteltével 25 dugvány hajtott ki átlagosan $3 \mathrm{~cm}$-es hajtásokkal, a vizsgált dugványok alja erősen megvastagodott. A kéreg felrepedt rajtuk, de gyökerek nem fejlődtek. Négy héttel a kezelést követően 36 dugvány hajtott ki átlagosan 3,5 cm-es hajtásokkal, a megvastagodott talpú dugványokon gyökeresedést nem tapasztaltam.

A S. caprea novemberben szedett és dugványozott, melegtalp nélkül nevelt kontroll dugványok esetében az első héten tízből két dugványon fejlődtek apró kalluszcsomók, és az epidermiszt áttört gyökérkezdemények. Két hét elteltével már tízből hét dugvány alsó fél centiméteres szakaszán, a talp közelében az epidermisz helyenként hosszában felrepedt, néhol kalluszcsomók törték át. A harmadik héten indult meg a kihajtás, 50-ből 20 dugványon fejlődtek 2-5 cm-es hajtások. Mind a nyolc dugvány alján kalluszcsomók fejlődtek a talp közelében, az egyikek egy 5 mm-es gyökér is nőtt. A gyökeresedés módja hasonló volt a Kelpak ${ }^{\circledR}$-kal fél órán keresztül felszívatott dugványoknál tapasztalthoz, de a kontroll dugványokon kevesebb gyökér fejlődött. Egy hónap múlva már 50-ből 38 dugványon 3-6 cm hosszú, kibomlott levelü hajtások fejlődtek. Nyolcból két vastagabb $(\mathrm{d}>1 \mathrm{~cm})$ dugványon $1 \mathrm{~cm}$-es gyökerek, a többin kalluszcsomók fejlőd- 
tek. A decemberi kontroll dugványok a dugványozást követően három héttel sem hajtottak még, 50 dugványon összesen két barka indult fejlődésnek. Nyolcból öt dugvány alsó 0,5-1 mm-es szakasza halványan barnult, nem gyökeresedtek, de feljebb a színük teljes hosszukban egészséges zöld volt. Öt héttel a dugványozás után minden dugványon 0,5-2 cm-es hajtások fejlődtek. Nyolcból nyolc dugvány alsó fél centiméterén fél mm-es szakaszokon felrepedt a héjkéreg, kilátszott a képződött kallusz. A januárban szedett 50 kontroll dugvány közül két hét elteltével 38 dugványon megindult a hajtáskezdemények fejlődése. Tízből öt dugvány teljes közegben lévő részén apró kalluszcsomók fejlődtek elszórtan. Két dugvány alsó részén a héj felhasadt a nagy mennyiségben képződő kallusztól, három dugvány esetében semmilyen változást nem tapasztaltam. Három hét elteltével ötből három dugványon 3-4 mm-es gyökerek fejlődtek (3-4 db/dugvány). Négy hét elteltével nyolcból nyolc dugványon fejlődtek gyökérkezdemények.

A S. caprea kontroll dugványok gyökeresedése azt bizonyította, hogy ez a klón serkentőszerrel végzett kezelés nélkül is gyökeresedik, csak lassabban és kevésbé egyenletesen, mint a Kelpak $^{\circledR}$ biostimulátorral.

\section{CA_M: melegtalpon}

A novemberben szedett és melegtalpon gyökereztetett összes $S$. caprea dugvány kihajtott a második héten. A közeg fölött 4-6-8 cm-es, 6 leveles hajtások, a föld alá került rügyekből 4-6 cm-es fehér etiolálódott hajtások fejlődtek.

A Kelpak ${ }^{\circledR}$-kal fél órán keresztül felszívatott $S$. caprea novemberben szedett és melegtalpon gyökereztetett dugványain egy hét után a gyökereztető közegben lévő rügyek kezdtek először hajtani (1-2 cm-esek), a dugványok alján apró kalluszcsomókat, és $1 \mathrm{db} 1 \mathrm{~cm}$-es gyökeret láttam. Két hét után a nyolcból nyolc dugvány alján apró kalluszcsomók törték át az epidermiszt, a legvastagabb dugványon négy 0,5-1,5 cm hosszú gyökér fejlődött (84. ábra). A dug-

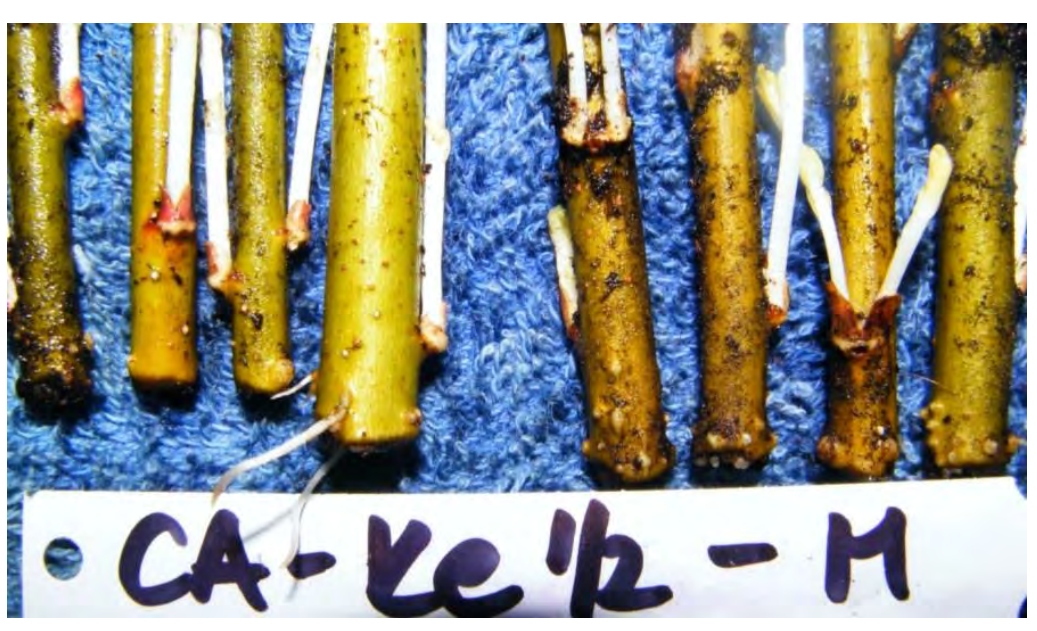

84. ábra: Kelpak ${ }^{\circledR}$-kal fél órán keresztül felszívatott, novemberben szedett $S$. caprea dugványok gyökeresedése melegtalpon, 2 héttel a dugványozást követően (fotó: Treerné, 2009) ványok felsőbb rügyei is kihajtottak. Három hét múlva az 50 dugványból 47 hajtott (2-6 cm-es hajtások). Nyolcból három dugvány alsó fél centiméteres szakaszán az epidermiszt áttört csomókból 2-15 mm hosszú gyökerek fejlődtek (3-4 db/dugvány). Három dugványon gyökeresedésnek nem láttam nyomát és barnul- 
tak, két dugványon áttörték az epidermiszt a kalluszcsomók. Nyolc héttel a kezelést követően az 50 dugványból 30 megbarnult, elhalt. Nyolcból hat dugvány teljesen megbarnult, elhalt. Két dugvány alsó fele barnult, felül még zöldek voltak, de gyökérképződést nem tapasztaltam. Ugyanakkor egy letört hajtás meggyökeresedett. A decemberben szedett, és Kelpak ${ }^{\circledR}-k a l$ fél órán keresztül felszívatott 50 dugvány közül a melegtalpon a kezelést követően két héttel 37 kihajtott, a fél centiméteres hajtásokon a levelek még nem kezdtek kiterülni. A vizsgált dugványok alsó 1,5 cm-es szakaszán az epidermisz elkezdett felhasadni, a dugványok alja kicsit megvastagodott. Az átlagosan $5 \mathrm{~mm}$ átmérőjü dugványok alja vastagodott meg leginkább, és itt hasadozott fel legjobban az epidermisz. Az 5-7 mm-nél nagyobb átmérőjü, vastagabb dugványok alja kevésbé duzzadt meg. Három héttel a kezelést követően az 50 dugványból már 46 zöldellt, 2-5 cm-es hajtásokat hozott melegtalpon. A dugványok alsó egy centiméteres szakaszán a héj néhol hoszszában felrepedt, máshol apró kalluszcsomók törték át. Négy héttel a kezelést követően ötből négy dugványon 1-2 db 10 mm-es gyökér fejlödött, az ötödik dugvány alja megbarnult. Öt hét elteltével az akkor 6-8 cm-es hajtások fele hervadásnak indult. Nyolcból hat dugvány alsó felekétharmada megbarnult, elhalt. Két dugvány alján csak az egyik oldal barnult, a dugványok zöld részén a héjkéreg hosszirányban repedt és kalluszcsomók jelentek meg. A januárban szedett összes dugvány kihajtott a kezelést követően két héttel. Az 1-5 cm hosszú hajtások (három-négy kibomlott levéllel) a kontrollhoz képest jelentősen fejlettebbek voltak. A dugványok alsó fél centiméteres szakaszán jelentek meg kalluszcsomók és gyökerek. Tízből négyen dugványonként 3-4 db 2 mm hosszú gyökér fejlődött. Hat dugványon a nagymennyiségű kalluszképződés következtében felhasadt a héjkéreg, és a kontrollhoz képest több kalluszcsomó törte át. Három hét elteltével nyolc dugványból haton dugványonként 3-4 db, 2-3 mm-es gyökér fejlödött, két dugványon apró kalluszcsomók jelentek meg. Négy hét elteltével minden dugvány alján 3-4 db 5-10 mm hosszú gyökér fejlödött.

A Kelpak ${ }^{\circledR}$-kal 8 órán keresztül felszívatott $S$. caprea novemberben szedett és melegtalpon gyökereztetett dugványain egy hét után kalluszcsomók jelentek meg a talp közelében. A második hét után a talp közelében áttörték a csomók az epidermiszt, és a dugványokon két-három rövid, átlagosan $5 \mathrm{~mm}$ hosszú gyökér fejlődött. A dugványokon a melegtalpon lévő kontrollhoz hasonlóan 3-5 cm-es hajtások fejlődtek. Három héttel a kezelés után 50-ből 44 dugvány kihajtott. Nyolcból hat dugvány alsó 5-10 mm-es szakaszán a kalluszcsomókból 5-10 mm hosszú gyökerek fejlődtek, egységesebbek méretben, mint ugyanekkor a Kelpak ${ }^{\circledR}$-kal csak fél órán keresztül felszívatott dugványok gyökerei. A másik két dugvány megbarnult, gyökerek nem fejlődtek rajtuk. Nyolc héttel a kezeléseket követően a dugványok fele elpusztult. Nyolcból öt dugvány alsó fele barna, felső része még zöld volt. Három dugványnak a teljes szaporítóközegben lévő szakasza, továbbá a földbe került hajtásrügyből fejlődött új hajtás etiolált 
szárrésze is gyökeres volt, dugványonként 8-10 db, átlagosan $10 \mathrm{~mm}$ hosszú gyökér fejlödött. A decemberben szedett, és Kelpak ${ }^{\circledR}$-kal 8 órán keresztül felszívatott 50 S. caprea dugványból két héttel a kezelést követően 30 dugványon megpattantak a rügypikkelyek, és alóluk 2-5 mm hoszszú hajtások fejlődtek. Minden dugvány alsó egy centiméteres szakaszán epidermiszt áttörő kalluszcsomók, gyökérkezdemények fejlődtek. A dugványok talpán szabályos körben kirajzolódott a megvastagodott kallusz, ahogyan a kambium osztódásnak indult. Három hét elteltével az 50 dugványból 49 kihajtott. A hajtások 3-5 cm hosszúak, egészséges élénkzöld színűek voltak. A dugványok alsó 10-15 mm-es szakaszán kalluszcsomók, gyökérkezdemények, és 5 mm hosszú gyökerek fejlődtek. Ez utóbbiak közül néhány beleszakadt a közegbe, ahogy a dugványokat a vizsgálat céljából kivettem a sejttálcából. Öt héttel a kezelések után a Kelpak ${ }^{\circledR}$-kal 8 órán keresztül felszívatott dugványokon fejlődtek a legnagyobb, 8-10 cm hosszú hajtások, melyeken a levelek szélesen kiterültek. Ugyanakkor a dugványok felén a hajtások hervadásnak indultak. Nyolcból három dugvány alsó fele a kalluszcsomókkal együtt megbarnult, elhalt. Öt dugványnak csak az egyik oldala barnult, függőleges irányban, a zöld részeken még a dugványok alsó fél centiméteres szakaszán elszórtan $5 \mathrm{~mm}$-es gyökerek fejlődtek. A januárban szedett 50 dugvány közül két hét elteltével 45 dugvány kihajtott, a Kelpak ${ }^{\circledR}$-kal fél órán keresztül felszívatott dugványokhoz hasonló mértékben. Tízből négy dugvány alsó fél centiméteres szakaszán több (3-6 db) 210(-15) mm hosszú gyökér fejlödött, a másik hat dugványon föleg kalluszcsomók törték át a héjat, és ezekből fejlődtek a gyökérkezdemények. Három héttel a kezelést követően nyolcból hat dugványon 5-8 db, 2-3 mm-es gyökér fejlődött, a másik két dugványon kalluszcsomók és gyökérkezdemények jelentek meg.

A NES oldattal kezelt, melegtalpon gyökereztetett $S$. caprea dugványok mindegyikénél már egy héttel a kezelést követően rendkívül erős kalluszburjánzást tapasztaltam: a dugványok alja bunkószerüen megvastagodott, rajtuk a héj hosszanti irányban felrepedt, hamar megkezdödött a dugványok talptól csúcs felé húzódó barnulása, pusztulása. A novemberi és a decemberi dugványokon a kezelést követő első három hétig még fejlődtek gyökerek (novemberi dugványoknál átlagosan $5 \mathrm{~mm}$-esek, decemberieknél átlagosan 7,5 mm-esek), de a januári dugványokon az intenzív kalluszosodással szinte egyidejüleg kezdődött a dugványok héjának barnulása, azok pusztulása.

A naftil-ecetsavval oldat formájában kezelt, melegtalpon gyökereztetett, novemberben szedett $S$. caprea dugványok alsó része már a kezelést követően egy héttel rendkívül erősen megvastagodott, az epidermiszt gyökerek törték át, és alul a dugványok héja megbarnult. A dugványok nem hajtottak ki. Két hét elteltével nyolcból három dugvány alja még tovább vastagodott, kallusztömeg látszott ki a felhasadt héjon, egy-két gyökér is fejlődött. A másik öt dugvány alja bunkószerűen megvastagodott, megbarnult. A kezelést követően három héttel sem hajtott ki 
a legtöbb dugvány; 50-böl kettőn fejlödtek csak rövid (2 cm-es) hajtások. Nyolc dugvány közül a legvastagabbon a héjkéreg hosszanti repedéseiböl egymás alatt $5 \mathrm{~mm}$-es gyökerek törtek elö, a többi dugvány alja bunkszerüen megvastagodott, felhasadozott, megbarnult. Nyolc hét elteltével az 50 dugványból négynek még zöld volt a föld feletti része, a többi megbarnult. Nyolcból nyolc dugvány teljesen megbarnult, talpi részük hasadozott, bunkószerüen megvastagodott. A decemberben szedett, melegtalpon gyökereztetett, NES oldattal kezelt dugványok két héttel a kezelés után nem hajtottak, a dugványok talpa, alsó 10-25 mm-es szakasza rendkívül erösen, bunkószerüen megvastagodott, erősen széthasadt, és sok helyen barnult. Három hét elteltével 50 dugványból egyetlen maradt zöld, a többi megbarnult. Nyolcból három dugvány alján 5-10 mm-es gyökerek fejlődtek, másik öt dugvány alsó fele bunkószerüen megvastagodott, megbarnult. Öt hét elteltével kilenc dugványból négy alja rendkívül erősen, bunkószerüen megvastagodott. Három dugvány alja enyhén, kettőé nem vastagodott, mind a kilenc dugvány megbarnult, elhalt. A januárban szedett összes dugvány két hét elteltével elpusztult, teljes hosszukban barnultak. Tízből tíz dugvány alsó fele teljesen megbarnult, talpuk megvastagodott. A későbbi vizsgálatok során is ezt tapasztaltam: az erősen megvastagodott talpú, felrepedt héjú dugványok mind megbarnultak, gyökeresedés nem történt.

A naftil-ecetsavval por formájában kezelt, melegtalpon gyökereztetett, novemberben szedett és dugványozott $52 \mathrm{~S}$. caprea dugványból egy hét után 13 hajtásrügyei megpattantak, és rajtuk $1 \mathrm{~cm}$-es, kibomló levelü hajtások fejlődtek. A dugványok alja rendkívül erősen, bunkószerüen megvastagodott, és nagy számban törtek át minden dugvány alsó $2 \mathrm{~cm}$-es szakaszán a gyökerek. Két hét elteltével a NES porral kezelt dugványokon a hajtások nem nőttek nagyobbra, mint a többi kezelésben részesült, melegtalpon gyökereztetett dugványon (bár ezek hajtottak ki legelőször). Nyolcból öt dugvány erősen megvastagodott alsó részén áttörték az epidermiszt a kalluszcsomók, és egységesen mindenhol átlagosan $5 \mathrm{~mm}$-es gyökerek fejlödtek belőlük és mellettük. A másik három dugvány alsó részén a héj megbarnult. Három héttel a kezelés után az 50 dugványból 45 db-on 5-8 cm-es zöld hajtások fejlődtek. Nyolcból három dugvány alsó fele megbarnult. Öt dugványon az epidermiszt áttört kalluszcsomók, és mindenhol rövid, 5 mm-es gyökerek fejlődtek. Nyolc hét elteltével az 50 dugványból már csak három élt. Nyolcból hét dugvány alja bunkószerủen megvastagodott, megbarnult, elhalt. A nyolcadik dugvány alsó $2 \mathrm{~cm}$-es szakaszán megbarnult, efölött 9 db 5-6 mm-es gyökér fejlödött rajta. A novemberben szedett $S$. caprea dugványok tehát nagyon jól reagáltak melegtalpon a NES porral történő kezelésre, már egy hét elteltével megindult az intenzív gyökeresedés, mely több mint három hétig tartott. Dugványonként 5-8, átlagosan $5 \mathrm{~mm}$ hosszú gyökér fejlődött. Nyolc héttel a kezelés után volt szembetűnő a dugványok barnulása, pusztulása, mely az intenzív kihajtás és a túlzott kalluszképződés következménye volt. A decemberben szedett 50 dugvány közül két hét elteltével 18 dugványon meg- 
pattantak a hajtásrügyek. A dugványok alsó fél centiméteres szakasza erősen megvastagodott, itt a héj felhasadt, és a dugványok talpán körben intenzív kalluszképződés volt megfigyelhető. A dugványokon feljebb elvétve apró kalluszcsomók fejlődtek. A kezelést követően három héttel 50-böl 45 dugványon 1-3 cm hosszú hajtások fejlődtek. Nyolcból négy dugványon 3-3 db, 5-10 mm-es gyökér fejlődött. A másik négy dugvány alja szintén megvastagodott, a felhasadt héjkéreg nyílásain keresztül látszott a kallusz. Öt hét elteltével a dugványokon fejlödött 3-5 cm-es hajtások fele zöld volt, másik fele elkezdett sárgulni, hervadni. Nyolcból hat dugványon a barnulás felfelé húzódott, bunkószerüen megvastagodott talpuk teljesen megbarnult. A másik két dugványon 5 mm-es gyökerek fejlödtek. A januárban szedett 50 dugvány közül a kezelést követően két héttel 33 kihajtott, a hajtások 5-20 mm hosszúak voltak, éppen kibomló levelekkel. Tízből tíz dugvány alja erősen megvastagodott, három bunkószerüen, hét pedig fordított $\mathrm{T}$ formában. $\mathrm{A}$ dugványok talpánál körben a kambiumgyürüből indult az erőteljes kalluszképződés. Három hét elteltével 45 dugvány hajtott ki 5-8 cm-es hajtásokkal. Nyolcból négy dugványon 3-4 db, átlagosan 5 mm-es gyökér fejlődött, a másik négy dugvány megbarnult, elhalt. Négy hét elteltével 44 dugványon voltak 5-8 cm-es hajtások. Nyolcból hat dugványon 4-5 db, 4-7 mm-es gyökér fejlödött, a másik két dugvány megbarnult.

A gyökereztető szer nélkül dugványozott, kontrollként a melegtalpon gyökereztetett, novemberben szedett $S$. caprea dugványokon már az elrakást követően egy héttel apró kalluszcsomók jelentek meg a talp közelében, a dugványok alsó 5-10 mm-es szakaszán. Két hét elteltével ezek áttörték az epidermiszt, és két dugványon, melyek átmérője meghaladta az egy centimétert, közel 10 mm-es gyökerek is fejlődtek. A dugványozást követő második héten a rügyekből 3-5 cm-es hajtások fejlődtek. Három hét elteltével az 50 dugványból 42 kihajtott, 4-8 cm-es, 6-8 leveles hajtásokat hoztak. Több dugványon 2-8 cm-es hajtások fejlödtek, ugyanakkor alul (akár a dugvány feléig) barnultak. Olyan dugványokat is találtam, melyek nem hajtottak, de gyökeresedtek. A dugványok alsó fél centiméteres szakaszán fejlödtek az apró gyökérkezdemények. A decemberben szedett kontroll dugványok közül a melegtalpon két hét elteltével 46 hajtott ki. A 2 cm-es zöld hajtásokon a levelek éppen kezdtek kibomlani. A dugványok alsó 10-15 mm-es részén az epidermisz $5 \mathrm{~mm}$-es szakaszokon hosszában felrepedt, és megjelent a kallusz. Egy vastagabb (d 10 mm) dugványon apró kalluszcsomók és gyökérkezdemények jelentek meg, az egyik helyen egy 1 mm-es gyökér fejlődött. Három hét elteltével az 50 dugványból 48 kihajtott, az 5-8 cm-es zöld hajtásokon a levelek már kibomlottak. A dugványok alját még mindig áttörő kalluszcsomók, illetve 1-2 mm hosszú repedések jellemezték. Két dugvány alulról hullámvonalszerüen fölfelé elkezdett barnulni. Öt hét elteltével a hajtások már 8-10 cm-esek voltak, de nagy részük elkezdett hervadni, lankadni. Nyolcból öt dugványon a hajtás megbarnault, elhalt. Három dugványon 2-3 db, 2-3 centiméteres, tövüknél elágazódó gyökér fejlödött. A januárban 
szedett 50 kontroll $S$. caprea dugványból melegtalpon a dugványozást követően két hét elteltével 48 hajtott ki, fél-másfél centiméter hosszú hajtásaikon a levelek ekkor kezdtek kibomlani. Tízből három dugvány alján 3-5 db, 5-10 mm hosszú, nem elágazódó gyökér fejlődött. A másik hét dugvány alsó fél centiméteres szakaszán apró kalluszcsomók nyomták fel az epidermiszt, helyenként át is törték azt. Három hét elteltével ötböl két dugványon az epidermiszt áttört kalluszcsomók, három dugványon 1-2 db, átlagosan 2 mm-es gyökér fejlődött.

A melegtalp alkalmazása egy héttel hozta elörébb a gyökeresedés időpontját. Melegtalpon a novemberi és januári kontroll dugványokon két héttel a kezelés után fejlődtek gyökerek (decemberben öt hét elteltével), melegtalp nélkül ugyanez az idő három hét volt, a decemberi dugványoknál csak kalluszcsomók törték át az epidermiszt.

\section{Salix rosmarinifolia $\mathrm{R03}$ gyökereztetése}

\section{RO_H: melegtalp nélkül}

A S. rosmarinifolia melegtalp nélkül gyökereztetett, Kelpak ${ }^{\circledR}-k_{\text {al }}$ fél órán keresztül felszívatott, novemberi dugványain a kezelést követő első héten még semmilyen változást nem tapasztaltam. Két hét elteltével 50-ből négy dugvány hajtásrügyei megpattantak, egy barka fejlődésnek indult, egyetlen dugvány alján láttam egy apró kalluszcsomót. A kezelés után három héttel 50 dugványból 19 kihajtott. Nyolcból hat dugvány alján gyökeresedésnek semmi jelét nem tapasztaltam, egy dugványon egy apró kalluszcsomó, a hetedik dugványon $2 \mathrm{db} 2 \mathrm{~cm}$ hosszú gyökér fejlődött. Nyolc hét elteltével továbbra is ezen a 19 dugványon voltak hajtások (3-6 cmesek). Nyolcból négy dugványon elágazódó gyökerek fejlődtek, melyek kalluszcsomók megjelenése nélkül törtek elö a dugványok oldalából. A négy gyökeres dugvány közül hármon van hajtás, a negyedik nem hajtott, de gyökeres volt. Egy másik dugvány kihajtott, de alul a gyökeresedésnek semmi jelét nem mutatta. A decemberben szedett dugványokon a hajtásrügyek három héttel dugványozás után sem pattantak meg, de megtartották fényes narancsszínüket, élőnek tủntek. Öt héttel a dugványozás után 50-ből 12 dugványon kezdődött meg a virágzati rügyekről a rügypikkely leválása, vagy a hajtáskezdemények fejlődése. A dugványok alja kismértékben sötétebbé vált, egyébként megörizték eredeti színüket. A januárban szedett 50 dugványon a kezelést követően két héttel összesen három hajtásrügy pattant meg, a dugványokon a gyökeresedésnek semmi jelét nem tapasztaltam. Két hét elteltével még mindig ez a három dugvány hajtott, öt dugvány közül a legvastagabbon $(\mathrm{d}=6 \mathrm{~mm})$ egy $5 \mathrm{~mm}$-es gyökér fejlödött. Három hét elteltével 22 dugvány kihajtott. Ötből két dugvány alján fejlődtek apró kalluszcsomók. 


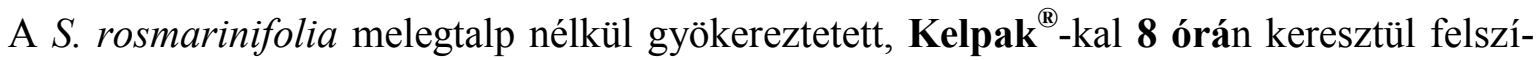
vatott, novemberi dugványain egy hét után még semmilyen változást nem tapasztaltam. Két héttel a kezelést követően több barka fejlődésnek indult. A dugványok színe még mindig egészséges narancs volt, de talpuk megfeketedett. Három héttel a kezelést követően 50 dugványból 29 kihajtott, vagy a barkák indultak fejlődésnek. A virágzati tengely elkezdett megnyúlni, de a portokok még nem nyúltak ki a murvapikkelyek közül. Gyökeresedésnek semmi jelét nem tapasztaltam, a dugványok talpa fekete volt. Nyolc hét elteltével 33 dugványon fejlődtek 2-6 cm hosszú hajtások, vagy megnyúlt, de még nem virágzó barkák. Nyolcból hét dugvány alján sem-

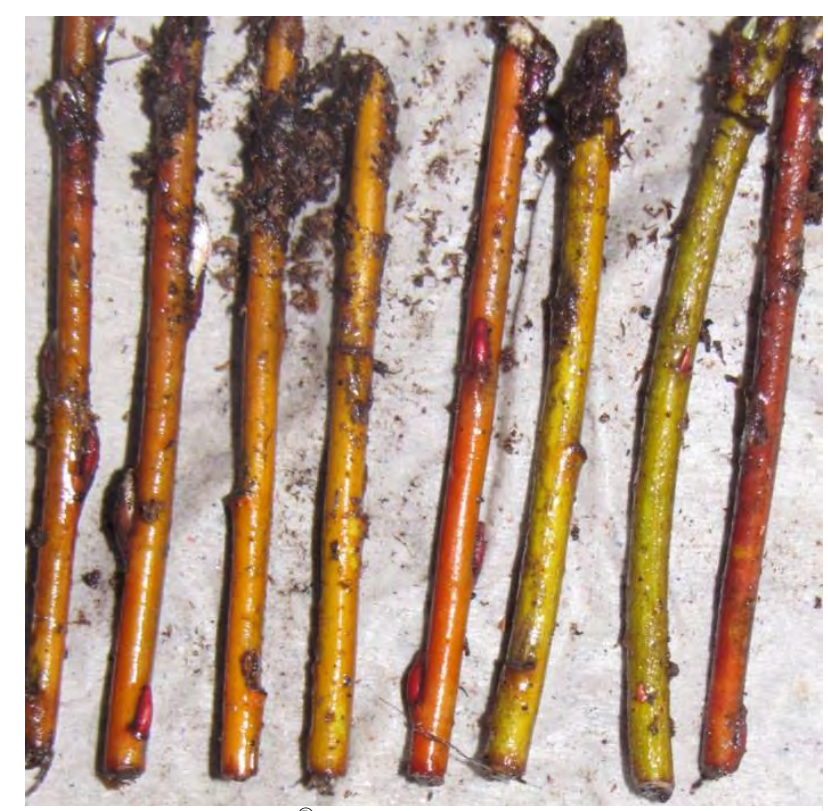

85. ábra: Kelpak ${ }^{\circledR}$-kal 8 órán keresztül felszívatott, decemberben szedett $S$. rosmarinifolia dugványok melegtalp nélkül, öt héttel a dugványozást követően (fotó: Treerné, 2010)

milyen változást nem tapasztaltam, a fekete talp kivételével a vesszők színe élénk narancs maradt. A nyolcadik, legvastagabb $(\mathrm{d}=7 \mathrm{~mm})$ dugvány alján elágazódó gyökerek fejlődtek. Ugyenezen a gyökeres dugványon felül hoszszabb (6 cm-es) hajtások is voltak. A decemberben szedett dugványokon a kezelést követően három héttel még semmilyen változást nem tapasztaltam. Öt hét elteltével 50-böl 18 dugványon fejlődtek 5-10 mm-es hajtáskezdemények, vagy megnyúlt bordó színủ barkák. A dugványok alsó részén sem tapasztaltam semmilyen változást, de mindegyik megtartotta dekoratív színét (85. ábra). A januári dugványokon két héttel a Kelpak ${ }^{\circledR}$-kal 8 órán keresztül végzett felszívatást követően még hajtásnak, gyökeresedésnek semmi jelét nem tapasztaltam, viszont 18 generatív rügy megpattant, és megindult a barkák fejlődése. Három hét elteltével már 25 dugványon indultak fejlődésnek a füzérek vagy 2-3 cm-es hajtások. Gyökeresedésnek még mindig nem tapsaztaltam jelét. Négy héttel a kezelés után 29 dugványon fejlődtek megnyúlt barkák vagy 3-4 cm hosszú hajtások. Ötből egy dugványon fejlődött egy 3 mm-es gyökér.

A naftil-ecetsavval oldat formájában kezelt, melegtalp nélkül gyökereztetett, novemberben szedett $S$. rosmarinifolia dugványok alja már a kezelést követően egy héttel megduzzadt, több helyen a megvastagodott szár kérge felhasadt, és kilátszott a kallusz. Két hét elteltével azonban a dugványok alja megbarnult vagy megfeketedett, már nem látszott a fehérlő kallusztömeg. Ugyanakkor több hajtáskezdemény és barka is megjelent. Három hét elteltével az 50 dugványból 23 darabon a virágzat-kezdeményekről leváltak a rügypikkelyek, és a füzérek virágzati tengelye megnyúlt, négy dugványon hajtáskezdemények fejlődtek. Nyolcból hét dug- 
ványon semmilyen változást nem tapasztaltam, a nyolcadik alján egy gyökérkezdemény törte át az epidermiszt. Nyolc hét elteltével 50 dugványból 19 kihajtott. Nyolc dugványból kettő alján 2$2 \mathrm{db}$ vastag, $15 \mathrm{~mm}$ hosszú gyökér fejlödött, a másik hat dugványon gyökeresedésnek semmi jelét nem tapasztaltam, ugyanakkor a héj színe élénk narancs maradt. A decemberben szedett dugványokon a NES oldattal való kezelés után három héttel még semmilyen változást nem tapasztaltam, nem hajtottak, nem gyökeresedtek, de eredeti színük megőrzése arról tanúskodott, hogy nem is pusztultak el. Öt hét elteltével 50-ből nyolc dugványon megpattantak a virágzati rügyek, és a rügypikkelyek alól bordó színű barkák indultak fejlödésnek. A dugványokon gyökeresedésnek semmi nyomát nem tapasztaltam, a héj színe továbbra is életteli narancssárga maradt. A januári 50 dugványból öt kihajtott a második héten. Tízből négy dugvány alsó 1-2 cm-es szakaszán apró kalluszcsomók jelentek meg. A kalluszburjánzás eredményeképpen a dugványok megvastagodott alsó részén a héjkéreg hosszanti irányban felrepedt. Három hét elteltével a hajtáskezdemények $1 \mathrm{~cm}$-esek voltak, négy barkán megpattantak a rügypikkelyek, ötből öt dugványon nem tapasztaltam gyökeresedésre utaló jelet. A kezelést követően négy héttel 24 dugványon megnyúltak a füzérvirágzatok. A dugványok talpa és alsó $0,5 \mathrm{~mm}$-es része megfeketedett, a héj színe narancssárga maradt. Gyökeresedésnek nem tapasztaltam jelét.

A melegtalp nélkül gyökereztetett, naftil-ecetsavval por formájában kezelt, novemberben szedett $S$. rosmarinifolia dugványokon a kezelést követően egy héttel még semmilyen változást nem tapasztaltam. Két hét elteltével sem tapasztaltam semmilyen változást, a dugványok alja sem feketedett. A kezelést követően három héttel 50-ből 13 dugvány hajtásrügyei megpattantak, 17 dugványon a füzérvirágzatok fejlődése indult meg. Nyolcból hét dugványon nem tapasztaltam a gyökeresedésnek semmilyen jelét, a nyolcadikon két apró kalluszcsomó kezdte áttörni az epidermiszt. Nyolc hét elteltével 50-böl 17 dugványon fejlődtek 2-3 cm-es hajtások, illetve megnyúlt tengelyü füzérvirágzatok. A közegből kiszedve nyolcból két dugványon látszódott a gyökeresedés megindulása; az egyiken egy $1 \mathrm{~cm}$-es gyökér fejlödött, a másikon egy kalluszcsomó törte át az epdiermiszt. A maradék hat dugványon gyökeresedésnek nem tapasztaltam jelét, de a héj megőrizte színe élénk narancssárga színét. A decemberben szedett, NES porral kezelt dugványok három héttel a kezelés után nem hajtottak, nyolcból hét dugvány alján gyökeresedésnek semmi nyomát nem tapasztaltam. Egy vastagabb $(\mathrm{d}=5,5 \mathrm{~mm})$ dugvány talpa megvastagodott. Öt héttel a kezelés után az 50 dugványból 14 dugványon megpattantak a hajtásrügyek, vagy bordó színü barkák utaltak a dugványok fejlődésére. Gyökeresedésnek semmi jelét nem tapasztaltam, ugyanakkor a dugványok teljes hosszukban (a szaporítóközegbe érő részükön is) élénk narancssárga színűek voltak. A januárban szedett dugványokon a kezelést követően két héttel gyökeresedésnek semmi jelét nem tapasztaltam. Ötvenből két dugványon megpattant egy-egy generatív rügy, és vöröslő barkák fejlődtek belölük. Három hét elteltével már tíz dugványon in- 
dultak fejlődésnek a barkák. Nyolcból három dugványon egy-egy apró kalluszcsomó kezdte áttörni az epidermiszt. Négy hét elteltével már 16 dugványon megpattantak a generatív rügyek.

A S. rosmarinifolia melegtalp nélkül gyökereztett, kontroll céljából novemberben szedett dugványain a dugványozást követően egy héttel nem tapasztaltam változást. Két héttel a dugványozás után 50-ből négy kezdett el hajtani, három dugványon a virágzati rügyek indultak fejlődésnek. Nyolcból a legvastagabb dugványon $(\mathrm{d}=6 \mathrm{~mm})$ egy kalluszcsomó törte át az epidermiszt, a többin gyökeresedésre utaló jelet nem tapasztaltam, de nem is feketedett a talpuk. Három hét elteltével 50 dugványból 21 kihajtott, illetve kivirágzott. A füzérvirágzatokban a porzók kinyúltak a murvapikkelyek közül, az érett portokok kinyúltak a virágzatokból. A dugványok alján gyökeresedésnek semmi jelét nem tapasztaltam, az alsó 0,5 mm-es szakaszuk (talpuk) besötétedett. Nyolc héttel a dugványozást követően 50-ből 29 dugványon fejlődtek 2-6 centiméteres, kibomlott keskeny leveles hajtások, illetve barkák. A dugványok alján gyökeresedésnek semmi nyomát nem tapasztaltam, talpuk megfeketedett, de feljebb a héj színe narancssárga maradt. A decemberi dugványokon három héttel a dugványozást követően a gyökeresedésnek semmi jelét nem tapsaztaltam. Nem hajtottak, egyetlen barkán pattant meg a rügypikkely. Öt hét elteltével 50-ből 13 dugványon pattantak meg elsősorban a generatív rügyek, de néhány hajtáskezdemény is megjelent. A rügypikkely alól előbújó barkák színe bordó volt, a nyél nélküli sárga portokok már látszottak a murvapikkelyek között. A dugványokon a gyökeresedésnek semmi jelét nem tapasztaltam, alsó fél mm-es szakaszuk megbarnult, de a héj megtartotta eredeti színét. A januári kezelések esetében a kontroll dugványoknál két hét elteltével 50-ből tíz dugványon indultak fejlődésnek a virágzatok, és megnyúlt bordó színű barkák fejlődtek belőlük. Hajtásfejlődést nem tapasztaltam. Tízből tíz dugványon gyökeresedésnek semmi jelét nem tapasztaltam, de - különösen a többéves ágrészekből vágott dugványok esetében - élénk, egészséges maradt a héj színe (a vékonyabb vesszőké narancspiros, az idősebb, vastagabb részeké zöld). A harmadik héten sem tapasztaltam változást, a közelebbről vizsgált dugványok közül a legvastagabbon $(\mathrm{d}=$ $7 \mathrm{~mm}$ ) fejlődött egyetlen kalluszcsomó. Négy hét elteltével 50 dugványból 22 kihajtott vagy kivirágzott. A dugványok alsó 2 mm-es szakasza megfeketedett, ezt leszámítva a vesszők színe még az eredeti volt.

\section{RO_M: melegtalpon}

A S. rosmarinifolia melegtalpon gyökereztetett, Kelpak ${ }^{\circledR}-k a l$ fél órán keresztül felszívatott, novemberben szedett dugványain a kezelést követően egy héttel semmi változást nem tapasztaltam. Két hét elteltével sem volt a gyökeresedésnek semmi nyoma, a dugványok alsó része (alsó fél centimétertől akár az alsó 4 cm-es szakaszig, a dugvány teljes hosszának közel feléig) megbarnult, megfeketedett, egyik sem hajtott. Három hét elteltével ugyanazt tapasztaltam, mint 
az előző vizsgálati időpontban, a dugványok alsó fele megfeketedett, látszólag elhalt. A decemberben szedett dugványok két héttel a kezelés után a gyökeresedésnek semmi jelét nem mutatták, az 50 dugvány közül egy sem hajtott, egyetlen dugványon kezdett megpattani egy virágzati rügy. Három hét elteltével 50-ből nyolc dugványon összesen $6 \mathrm{db} 1 \mathrm{~cm}$-es hajtáskezdemény és két barka fejlődött. A rövid hajtások egyikének csúcsán is fejlődött egy barka. Nyolcból egyetlen dugványon fejlődött egy apró, epidermiszt áttört kalluszcsomó. Öt héttel a kezelést követően 50ből hét dugványon fejlődtek 1-2 cm-es hajtások 3-5 apró levéllel. Nyolcból hét dugványon 2-20 mm hosszan alulról felfelé húzódó barnulás jelent meg. A nyolcadik dugvány nem barnult, a legalján egy apró kalluszcsomó törte át az epidermiszt. A januárban szedett 50 közül a fél órás Kelpak $^{\circledR}$-os felszívatást követően két héttel tíz dugványon pattantak meg hajtás- illetve virágzati rügyek. Tízből nyolc dugvány alsó $1 \mathrm{~cm}$-es szakaszán egy-egy kalluszcsomó törte át a héjkérget, ami hosszanti irányban felrepedezett az intenzív kalluszképződés következtében. Három hét elteltével négy dugványon 1-2 cm-es hajtások fejlődtek. Nyolcból hét dugvány alja barnult.

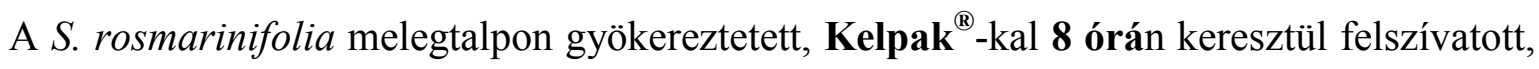
novemberben szedett dugványain a kezelést követően egy héttel még semmilyen változást nem tapasztaltam. Két hét elteltével 50-böl kilenc dugványon megjelentek a hajtáskezdemények. Gyökeresedésnek nem tapasztaltam jelét, a dugványok alsó $5 \mathrm{~mm}$-es szakasza megbarnult, talpuk megfeketedett. Három héttel a kezelést követően 50 dugványból 25 kihajtott, a barkák eredeti méretük kétszeresére nyúltak. Nyolc dugványból az egyiken $5 \mathrm{db}$ 2-3 mm-es gyökér törte át az epidermiszt, kallusz nem képződött. Ugyanezen a dugványon $3 \mathrm{db} 3 \mathrm{~cm}$-es hajtás is fejlődött. A másik hét dugvány legalja (legfeljebb a dugványok alsó $5 \mathrm{~mm}$-es szakasza) megbarnult, de a többi részen megtartották eredeti vesszőszínüket. Ezek közül három dugványon fejlődtek hajtások. Nyolc héttel a kezelést követően 50-böl 21 dugványon voltak hajtások vagy barkák. Nyolcból három dugvány gyökeresedett, de ezek közül az egyik már elpusztult, egy másikon a gyökér a dugványon fejlődött új hajtás alsó részéböl tört elö. A másik öt dugványon gyökeresedésnek semmi nyomát nem tapasztaltam. Ez utóbbiak közül három dugvány teljesen, kettőnek az alsó 2 cm-es szakasza megbarnult, felül megtartották eredeti színüket. A decemberben szedett és Kelpak $^{\circledR}$-kal 8 órán keresztül felszívatott 50 dugvány közül két héttel a kezelést követően csak öt dugványon indultak fejlődésnek a rügyek, mindegyik generatív; és vöröslő barkák jelentek meg rajtuk. Gyökeresedésnek semmi jelét nem tapasztaltam. Három hét elteltével 50-ből 11 dugványon fakadtak a rügyek; kettőn hajtáskezdemények fejlödtek, kilenc dugványon barkák piroslottak. Nyolcból négy dugvány alsó fél centiméteres szakasza megbarnult. Öt hét elteltével a korábban fejlődésnek indult 11 dugvány közül kettőn elhervadtak a hajtások, a maradék kilenc dugványon 2-3 centiméteresek voltak, nagyobbak, mint ugyanekkor a Kelpak ${ }^{\circledR}-k a l$ csak fél órán keresztül felszívatott dugványok hajtásai. Nyolcból három dugvány alsó 5-20 mm-es szakasza 
megbarnult, bár az egyik dugványon még zöld hajtások voltak. A további három dugványnak csak az alsó 2 mm-es szakasza barnult meg, két dugvány megtartotta eredeti színét. A januárban szedett 50 dugvány közül a kezelést követően két hét elteltével 11 darabnál indultak fejlődésnek a rügyek. A generatív rügyekből megnyúlt barkák, a vegetatív rügyekből 5-20 mm-es hajtások fejlődtek. Tízből hat dugvány alsó felén egy-egy kalluszcsomó kezdte áttörni az epidermiszt, illetve az néhol hosszirányban felrepedt, négy dugványnál nem tapasztaltam változást. Három héttel a kezelést követően 15 dugvány hajtott. Nyolcból egy vastagabb $(\mathrm{d}=6 \mathrm{~mm})$ dugványon apró kalluszcsomók törték át az epidermiszt. Négy hét elteltével 23 dugványon fejlődtek hajtások vagy megnyúlt barkák. Nyolcból négy dugványon 2-3 mm-es gyökerek fejlődtek az epidermiszt áttört kalluszcsomókból.

A S. rosmarinifolia melegtalpon gyökereztetett, naftil-ecetsavval oldat formájában kezelt, novemberben szedett dugványok mindegyikének alja bunkószerüen megvastagodott volt a kezelést követően egy héttel, és ezekből a megvastagodott részekből több helyen 1-2 mm-es gyökerek törtek elő. A dugványok talpa barna volt. Két héttel a kezelések után 50-ből hat dugványon pattantak meg a rügyek. A dugványok erősen megvastagodtak, majd elpusztultak, alsó fél centiméteres szakaszuk megbarnult. Három hét elteltével 50 NES oldattal kezeltből 12 dugványon 3-5 cm-es hajtások fejlődtek. Nyolcból egy dugvány talpa körben megvastagodott a nagy mennyiségben képződött kallusztól. Öt dugvány alja erősen megvastagodott, megbarnult, ezek közül két dugvány megvastagodott, barna alsó részéből egy-egy 2 mm-es gyökér fejlődött. A legvékonyabb $(\mathrm{d}=2,3 \mathrm{~mm})$ két dugvány alja nem vastagodott meg, de alsó $3 \mathrm{~cm}$-es szakaszuk megfeketedett. Nyolc hét elteltével 50-ből hat dugványon fejlődtek 3-6 cm-es hajtások. Nyolcból egy dugvány teljesen megbarnult és elhalt, bár korábban fejlődött rajta hajtás. A másik hét dugvány alsó 1-3 cm-es szakasza megbarnult, feljebb megőrizte eredeti narancssárga színét. A decemberben NES oldattal kezelt dugványokon az első héten nem fejlődtek hajtások. A kezelést követően egy héttel nyolcból három dugvány alsó része megvastagodott, az epidermisz hosszanti irányban felrepedt, a másik öt dugvány alja megbarnult. Két hét elteltével még mindig nem hajtottak. Nyolcból négy dugvány alja bunkószerüen megvastagodott volt, de alsó 0,5-2 cm-es részük megbarnult, elhalt. Négy hét elteltével 50-ből három dugványon megpattantak a hajtásrügyek, a rügypikkelyek alól fél centiméteres hajtáskezdemények fejlődtek. Nyolcból nyolc dugványon tapasztaltam barnulást. Három dugványnak csak az alsó fél centiméteres szakasza barnult meg, három dugványnak a fele, a másik két dugvány teljes hosszán megbarnult, elhalt. A januárban szedett, NES oldattal kezelt $S$. rosmarinifolia dugványokon a kezelést követően két héttel megindult a hajtásfejlődés. Tízből hét dugványon fejlődtek fél-másfél centiméter hosszú zöld hajtások. Hat dugvány meggyökeresedett, mindegyiken 1-3 db, 2-3 cm hosszú, elágazódó gyökerek fejlődtek. Négy dugvány alja erősen megvastagodott és bebarnult, néhányon a hossz- 
irányban felrepedt héjkéreg alatt látszott a differenciálatlan kallusztömeg. Három héttel a kezelés után nyolcból három dugvány alsó része megvastagodott, öt dugvány alja megbarnult. Négy hét elteltével 50 közül 24 dugványon indultak fejlödésnek a barkák, virágzati tengelyük megnyúlt. Nyolcból egyetlen dugványons sem fejlődött gyökér; öt dugvány megfeketedett, elhalt, három alja megduzzadt, megbarnult.

A S. rosmarinifolia melegtalpon gyökereztetett, naftil-ecetsavval por formájában kezelt, novemberben szedett dugványokon a kezelést követően a tizedik napon tízből három dugványon 1-15 mm hosszú gyökerek fejlődtek. Két héttel a kezelést követően 50 dugvány közül négy hajtott ki. Nyolcból kettő alsó része megvastagodott, a dugványok talpán a kalluszréteg kismértékben kitüremkedett, hat dugvány alsó pár mm-es szakasza megfeketedett. Három hét elteltével 50ből öt dugvány hajtott ki (3-5 cm hosszú hajtások). Nyolcból három dugvány talpi része körben megvastagodott, rajta kalluszcsomók fejlődtek (86. ábra). Öt dugvány alsó fél centiméteres szakasza teljesen megbarnult. A NES porral kezelt novemberi dugványokon a kezelés után nyolc héttel gyökeresedésnek semmi jelét nem tapasztaltam. Nyolcból négy dugvány alsó 5-20 mm-es szakasza megbarnult, fölötte a héj megőrizte eredeti narancssrága színét. Az eddig kihajtott növényeken a hajtások lankadtak, hervadtak. A decemberben szedett 50 dugványból a kezelést követő második héten nyolc dugványon megpattantak a virágzati rügyek, és vöröslő barkák fejlődtek. A dugványok alsó egy centiméteres szakasza kismértékben megvastagodott, apró kalluszcsomók kezdték áttörni az epidermiszt. Három héttel a kezelést követően 50 dugványból 27 kihajtott; 2 cm-es hajtáskezdemények vagy barkák fejlődtek rajtuk. Nyolcból két dugvány alsó 2 centiméteres szakaszán apró kalluszcsomók törték át az epidermiszt. Öt hét elteltével az

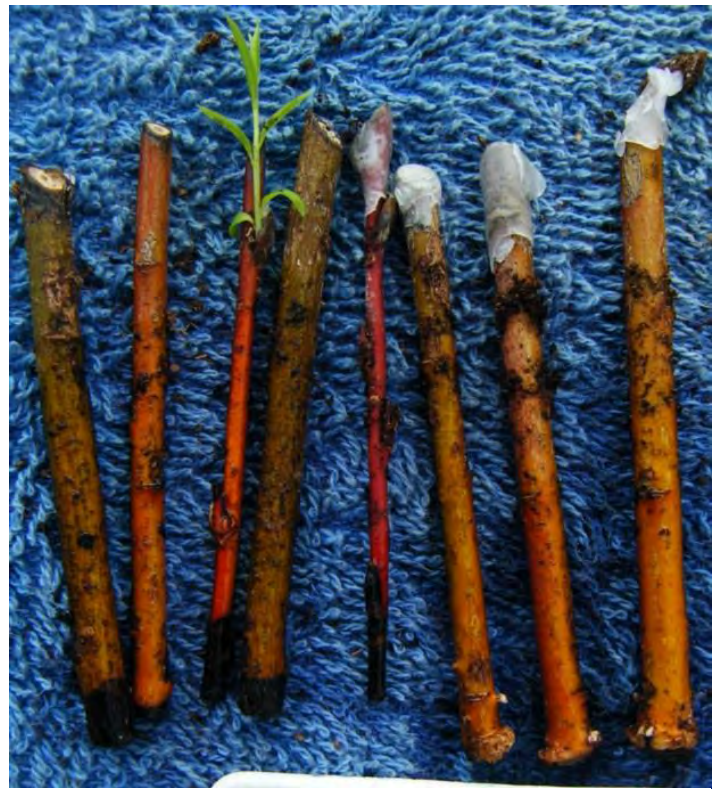

86. ábra: Novemberben szedett és dugványozott $S$. rosmarinifolia dugványok (melegtalpon,

NES porral kezelve) 3 héttel a dugványozást követően (fotó: Treerné, 2009)
50 decemberben szedett, NES porral kezelt dugvány közül 24 dugványon fejlődtek 2-5 cm-es hajtások. Nyolcból öt dugvány alsó 2 cm-es szakasza megbarnult, három megtartotta eredeti színét, és rajtuk apró, epidermiszt áttörő kalluszcsomók jelentek meg. A januárban szedett és NES porral kezelt $50 \mathrm{~S}$. rosmarinifolia dugvány közül a dugványozást követően két hét elteltével 11 kihajtott, a hajtások hossza $10 \mathrm{~mm}$ volt, a levelek még nem terültek ki rajtuk. Tízből öt dugvány alsó egy centiméteres szakaszán apró kalluszcsomók kezdték áttörni az epidermiszt. A másik öt dugványnál gyökeresedést nem tapsaztaltam, négy dugvány alja bunkószerűen meg- 
vastagodott. Három hét elteltével nyolcból három dugvány alsó része megfeketedett, öt dugvány talpi része kicsit megvastagodott, és itt kalluszcsomók törték át az epidermiszt. Négy hét elteltével nyolc dugványon fejlődtek 1-3 cm-es hajtások. Nyolcból nyolc dugvány nem gyökeresedett. Hat dugvány alsó része megfeketedett, a másik kettő megőrizte eredeti színét.

A S. rosmarinifolia melegtalpon kontroll gyanánt gyökereztett, novemberben szedett dugványain az első héten hajtásfejlődést nem tapasztaltam. A dugványok közegben lévő részén elszórtan pontszerüen feldomborodott az epidermisz, valószínüleg a kalluszcsomók nyomták fel, melyek még nem voltak képesek áttörni. Két hét elteltével 50 dugvány közül három kihajtott, a dugványok alsó fél centiméteres szakaszán a héj megfeketedett. Három hét elteltével 50-ből tíz dugványon fejlődtek 2-5 cm hosszú hajtások. Az előző heti eredményekhez képest nem tapasztaltam változást, a dugványok nem barnultak tovább, és az alsó, megbarnult rész felett megőrizték eredeti élénk narancssárga színüket. Nyolcból két dugványon fejlődtek hajtások, de gyökeresedésnek ezeken sem tapasztaltam jelét. Nyolc héttel a kezelést követően 50 dugvány közül 11 kihajtott. Nyolcból egy dugványon a rügypikkely alól előbújt a barka, a dugvány alsó $2 \mathrm{~cm}$-es szakasza megbarnult, feljebb megőrizte eredeti színét. Nyolcból nyolc dugvány alsó 1-4 cm-es szakasza megbarnult vagy megfeketedett, feljebb megtartották narancssárga színüket. Gyökeresedésnek semmi nyomát nem tapasztaltam. A decemberben szedett, melegtalpon kontrollként gyökerezetett 50 S. rosmarinifolia dugvány közül a kezeléseket követően két héttel két dugványon fejlődtek 10 mm-es hajtáskezdemények. Gyökeresedésnek semmi jelét nem tapasztaltam. Három hét elteltével 50-ből 15 hajtott ki, tíz dugványon 1-2 cm-es hajtások, öt dugványon pirosló barkák fejlődtek. Az egyik barka egy rövidhajtás csúcsán fejlődött. Nyolcból az egyik dugványon egyetlen apró kalluszcsomó kezdte áttörni az epidermiszt, hét dugványon gyökeresedésnek semmilyen jelét nem tapasztaltam, alsó fél mm-es talpi részük megbarnult. Öt hét elteltével 22 dugványon indultak fejlődésnek a rügyek; 16 dugványon 2-3 cm-es hajtások fejlődtek, a többin a barkák nyúltak meg. Nyolcból nyolc dugvány alsó 5-30 mm-es szakasza megbarnult. A januárban szedett dugványok esetében a dugványozást követően két héttel 50 dugványból 14 kihajtott, a rajtuk lévő barkák elkezdtek megnyúlni. A hajtások 1-2 cm hosszúságúak voltak, több barka a zöld hajtások csúcsán fejlődött. Tízből négy dugvány alján egy-egy kalluszcsomó, illetve abból fejlődő gyökér kezdte áttörni az epidermiszt, a többi dugvány alsó 1-4 mm-es szakasza elkezdett barnulni. Három héttel a dugványozást követően a hajtások 2-4 cm-esek voltak, nyolcból egy dugványon fejlödtek 2-3 mm-es gyökerek. 


\section{M10. Gyökereztetési kísérlet fotódokumentációja}

2009. novemberben szedett és dugványo-

zott $S$. caprea dugványok gyökeresedése

melegtalp kezelés nélkül (XI_CA_H)

3 héttel a dugványozást követően
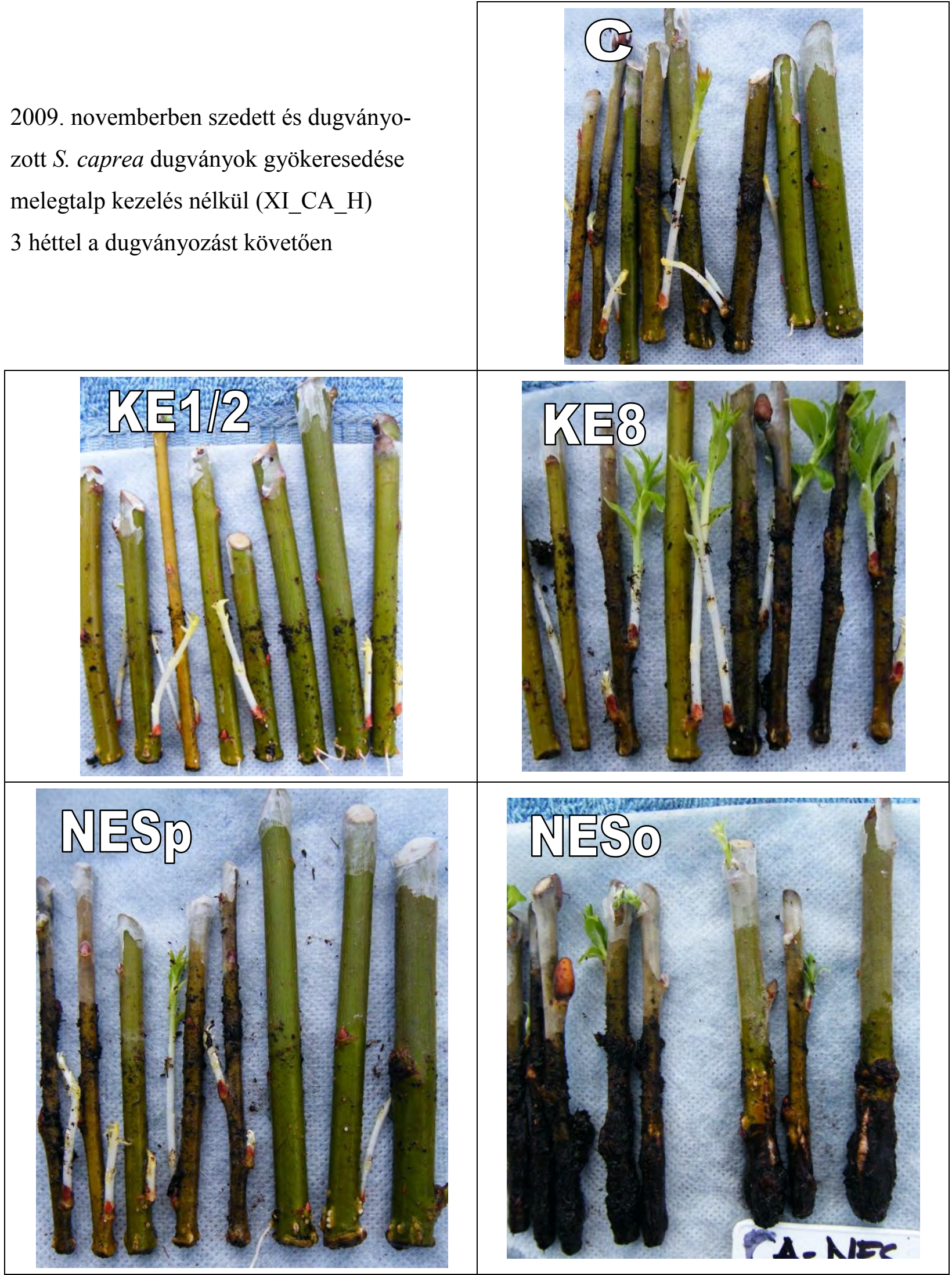
2009. novemberben szedett és dugványozott $S$. caprea dugványok gyökeresedése melegtalp kezeléssel (XI_CA_M) 3 héttel a dugványozást követően

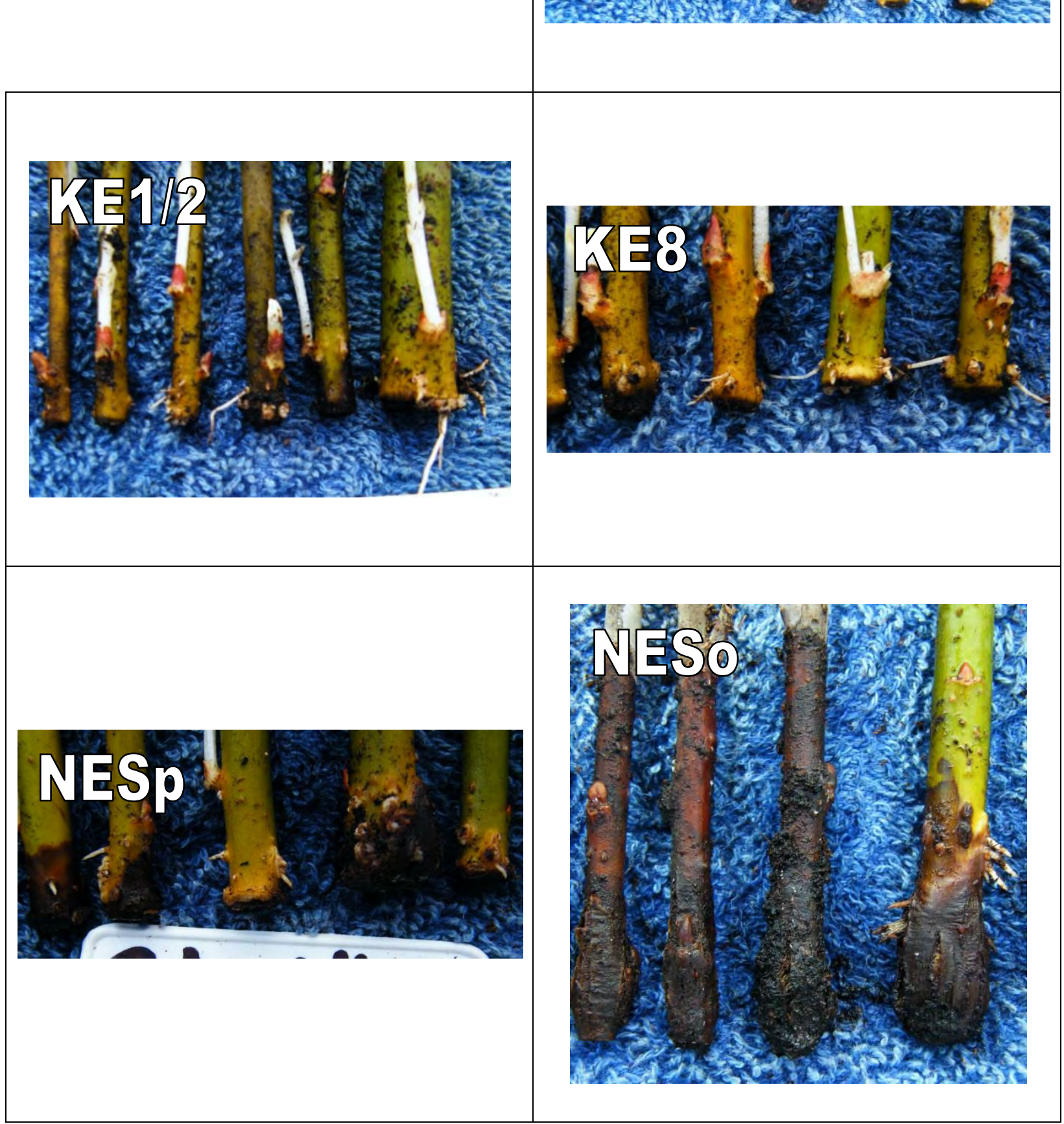


2009. decemberben szedett és dugványozott $S$. caprea dugványok gyökeresedése melegtalp kezelés nélkül (XII_CA_H) 5 héttel a dugványozást követően
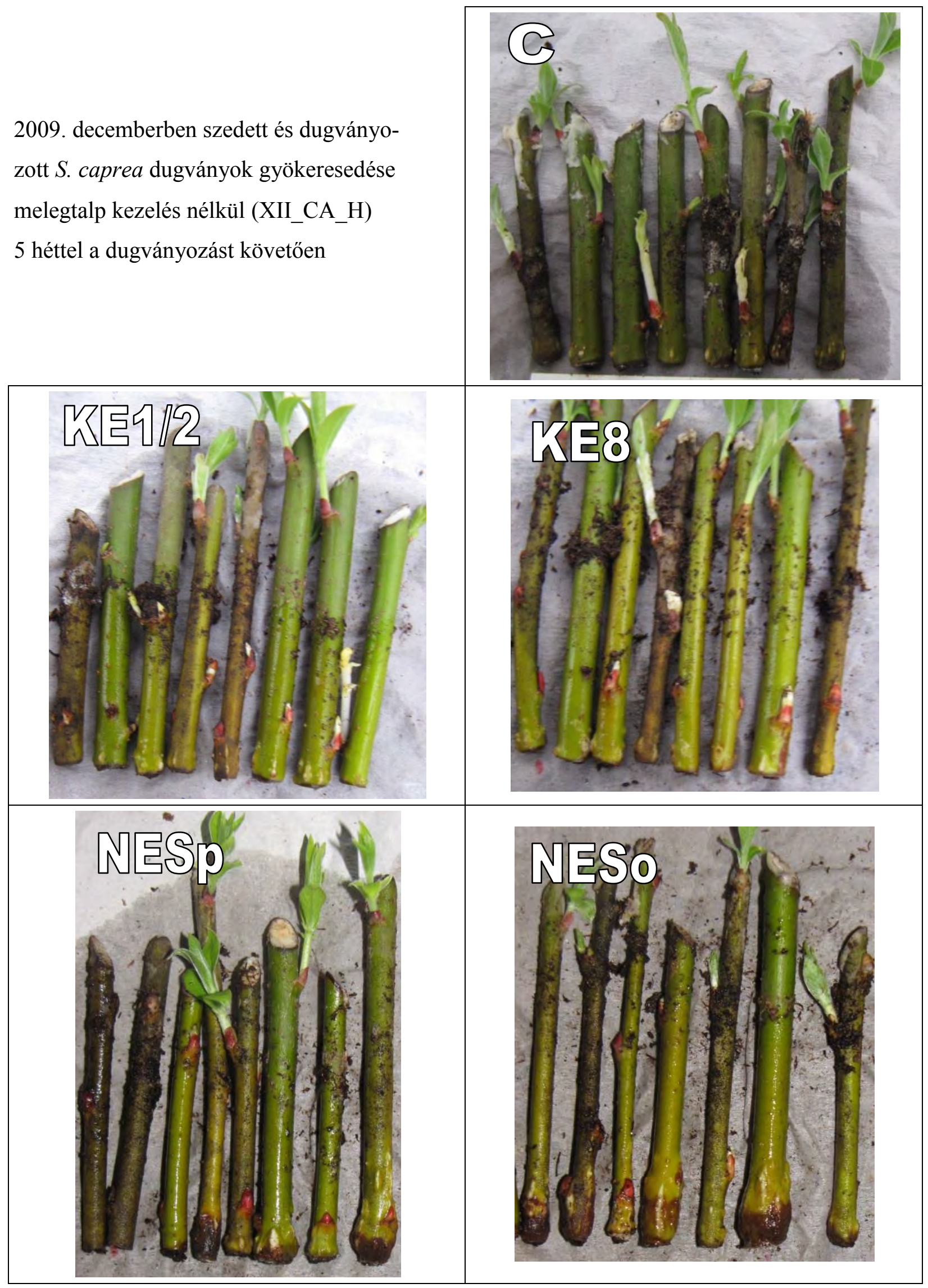
2009. novemberben szedett és dugványozott $S$. rosmarinifolia dugványok

gyökeresedése melegtalp kezelés nélkül (XI_RO_H)

3 héttel a dugványozást követően

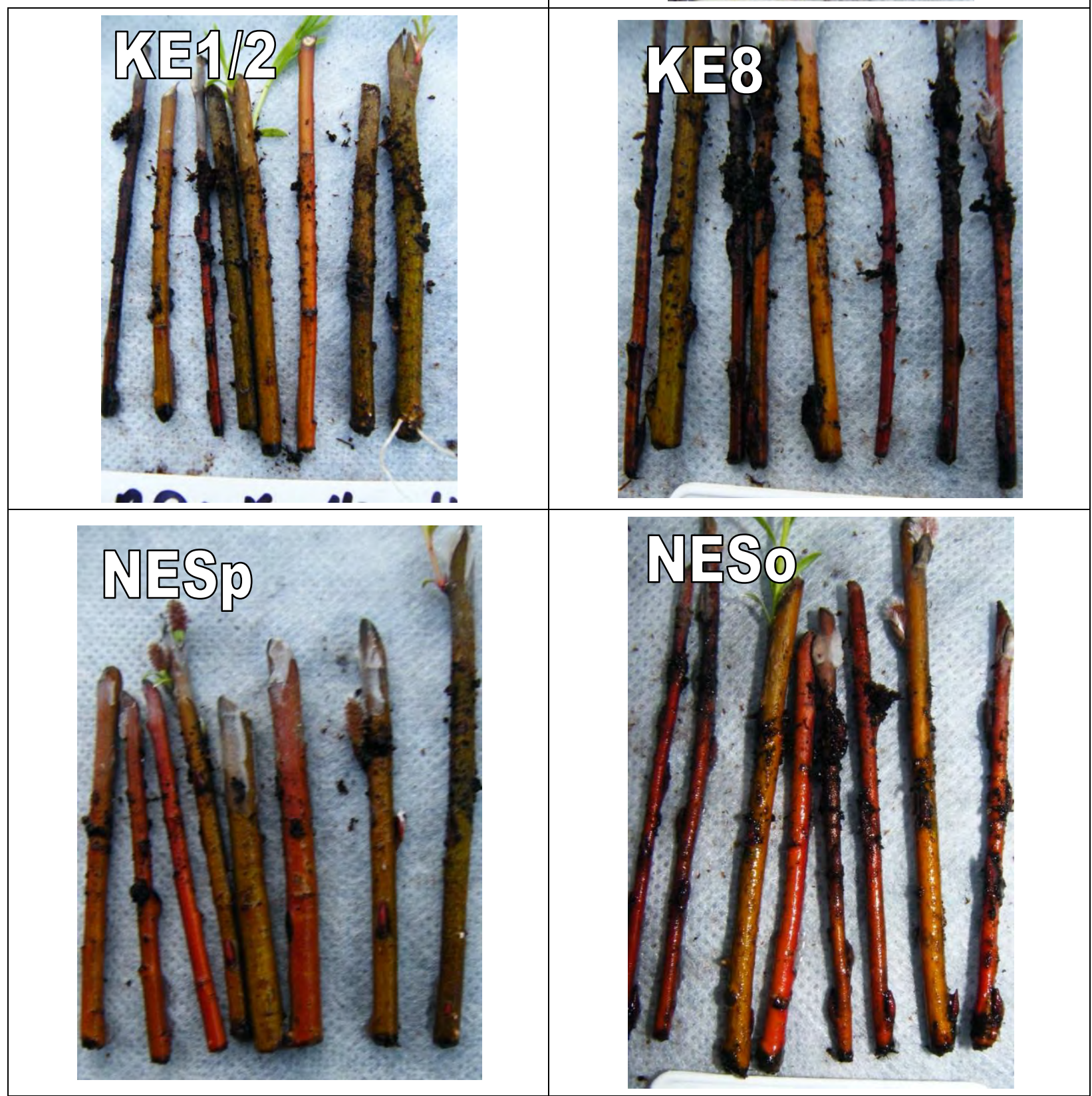


2009. novemberben szedett és dugványozott $S$. rosmarinifolia dugványok gyökeresedése melegtalp kezeléssel (XI_RO_M) 3 héttel a dugványozást követően
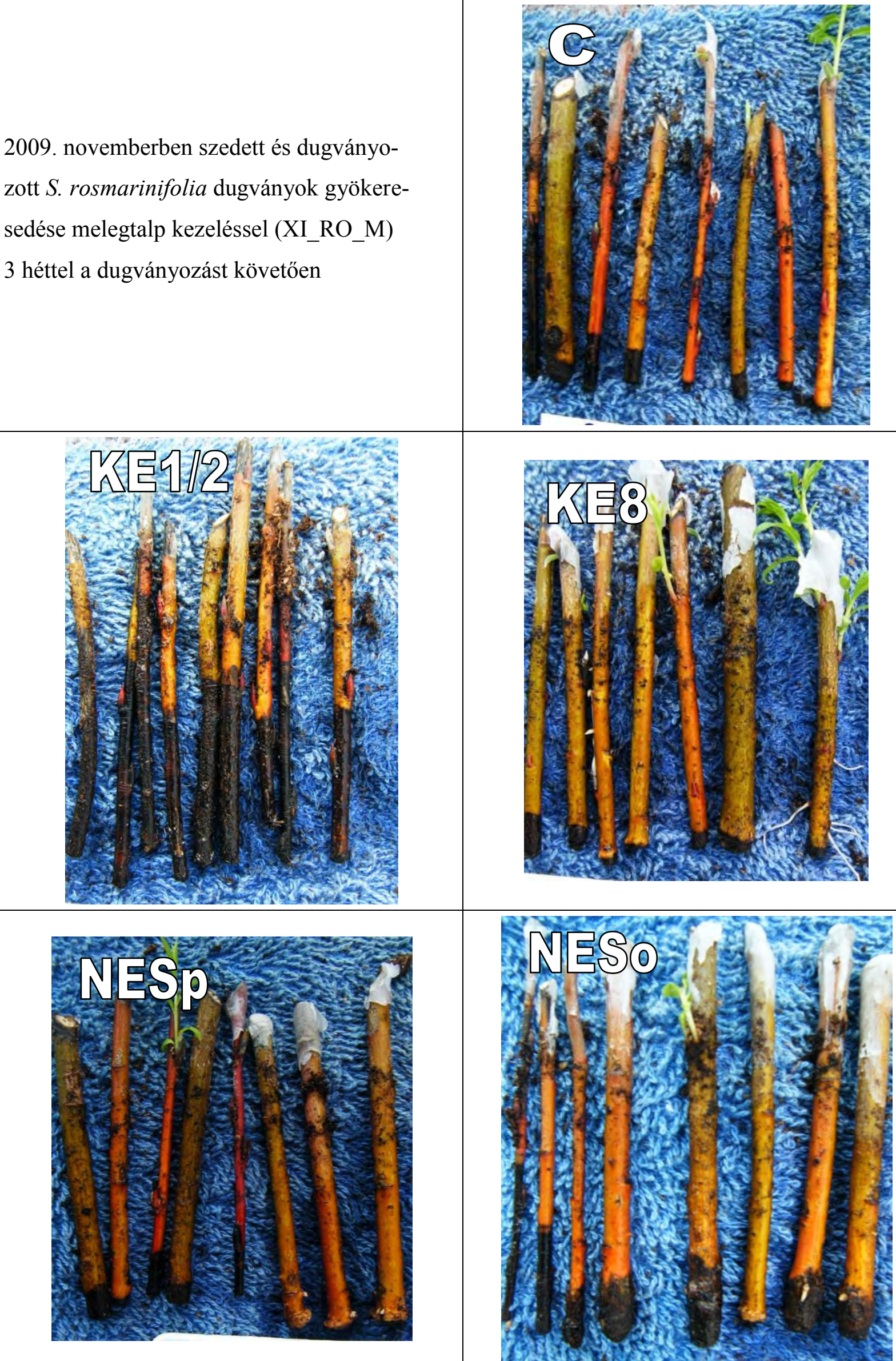
2009. decemberben szedett és dugványozott $S$. rosmarinifolia dugványok gyökeresedése melegtalp kezelés nélkül (XII_RO_H)

5 héttel a dugványozást követően
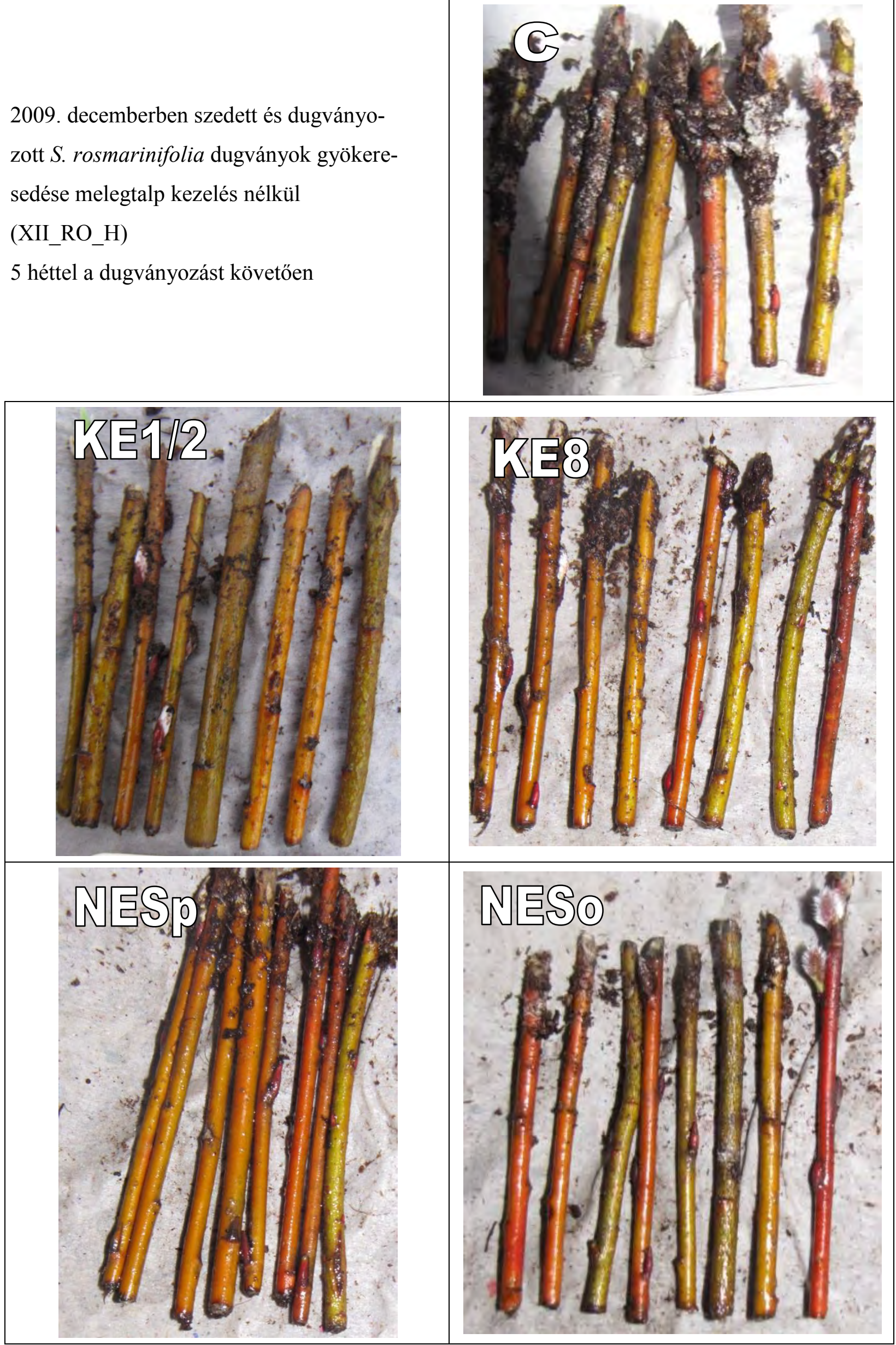
2009. decemberben szedett és dugványozott $S$. rosmarinifolia dugványok gyökeresedése melegtalp kezeléssel (XII_RO_M) 5 héttel a dugványozást követően

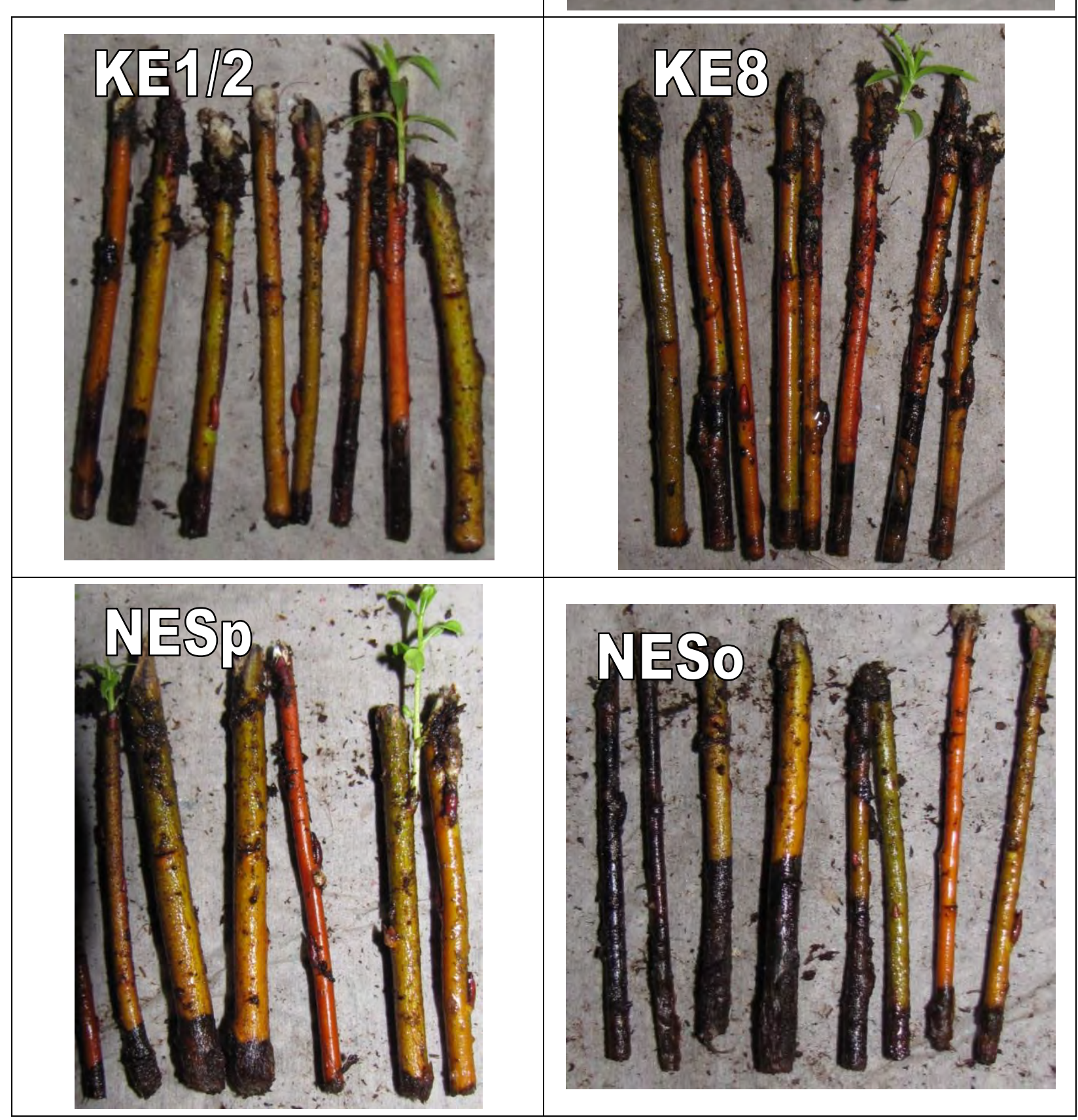




\section{M11. Gyökereztetési kísérlet bonitálási táblázatai}

\begin{tabular}{|l|l|l|l|l|l|l|l|l|l|l|}
\hline $\begin{array}{l}\text { RO 2009. } \\
\text { XI. havi }\end{array}$ & C-M & C-H & Ke1/2-M & $\begin{array}{l}\text { Ke1/2- } \\
\text { H }\end{array}$ & Ke8-M & Ke8-H & $\begin{array}{l}\text { NESp- } \\
\text { M }\end{array}$ & $\begin{array}{l}\text { NESp- } \\
\text { H }\end{array}$ & $\begin{array}{l}\text { NESo- } \\
\text { M }\end{array}$ & NESo-H \\
\hline 0 & 50 & 43 & 59 & 45 & 44 & 40 & 50 & 42 & 44 & 45 \\
\hline 1 & 2 & 1 & 2 & 5 & 8 & 1 & 3 & 5 & 7 & 3 \\
\hline 2 & 0 & 2 & 0 & 0 & 0 & 1 & 0 & 1 & 0 & 1 \\
\hline 3 & 0 & 4 & 0 & 3 & 1 & 1 & 0 & 2 & 0 & 3 \\
\hline 4 & 1 & 2 & 0 & 2 & 1 & 5 & 0 & 4 & 0 & 1 \\
\hline $\mathrm{X}$ & 0 & 0 & 0 & 0 & 0 & 1 & 0 & 0 & 0 & 0 \\
\hline$\Sigma(\mathrm{db}):$ & 53 & 52 & 61 & 55 & 54 & 48 & 53 & 54 & 51 & 53 \\
\hline
\end{tabular}

\begin{tabular}{|l|l|l|l|l|l|l|l|l|l|l|}
\hline $\begin{array}{l}\text { RO 2009. } \\
\text { XII. havi }\end{array}$ & C-M & C-H & Ke1/2-M & Ke1/2-H & $\begin{array}{l}\text { Ke8- } \\
\text { M }\end{array}$ & $\begin{array}{l}\text { Ke8- } \\
\text { H }\end{array}$ & $\begin{array}{l}\text { NESp- } \\
\text { M }\end{array}$ & $\begin{array}{l}\text { NESp- } \\
\text { H }\end{array}$ & $\begin{array}{l}\text { NESo- } \\
\text { M }\end{array}$ & $\begin{array}{l}\text { NESo- } \\
\text { H }\end{array}$ \\
\hline 0 & 44 & 30 & 49 & 44 & 47 & 28 & 42 & 23 & 49 & 46 \\
\hline 1 & 0 & 7 & 1 & 5 & 0 & 20 & 1 & 11 & 0 & 2 \\
\hline 2 & 0 & 7 & 0 & 0 & 0 & 1 & 5 & 2 & 1 & 1 \\
\hline 3 & 4 & 3 & 0 & 1 & 3 & 2 & 1 & 5 & 0 & 1 \\
\hline 4 & 2 & 0 & 0 & 0 & 0 & 1 & 1 & 8 & 0 & 0 \\
\hline $\mathrm{X}$ & 0 & 0 & 0 & 0 & 0 & 0 & 0 & 0 & 0 & 0 \\
\hline$\Sigma(\mathrm{db}):$ & 50 & 47 & 50 & 50 & 50 & 52 & 50 & 49 & 50 & 50 \\
\hline
\end{tabular}

\begin{tabular}{|l|l|l|l|l|l|l|l|l|l|l|}
\hline $\begin{array}{l}\text { RO 2010. } \\
\text { I. havi }\end{array}$ & C-M & C-H & $\begin{array}{l}\text { Ke1/2- } \\
\text { M }\end{array}$ & $\begin{array}{l}\text { Ke1/2- } \\
\text { H }\end{array}$ & $\begin{array}{l}\text { Ke8- } \\
\text { M }\end{array}$ & Ke8-H & $\begin{array}{l}\text { NESp- } \\
\text { M }\end{array}$ & $\begin{array}{l}\text { NESp- } \\
\text { H }\end{array}$ & $\begin{array}{l}\text { NESo- } \\
\text { M }\end{array}$ & $\begin{array}{l}\text { NESo- } \\
\text { H }\end{array}$ \\
\hline 0 & 45 & 44 & 50 & 31 & 41 & 40 & 44 & 43 & 49 & 39 \\
\hline 1 & 1 & 0 & 0 & 5 & 5 & 3 & 6 & 2 & 0 & 9 \\
\hline 2 & 1 & 3 & 0 & 2 & 2 & 0 & 0 & 1 & 1 & 0 \\
\hline 3 & 3 & 3 & 0 & 7 & 2 & 5 & 0 & 0 & 0 & 2 \\
\hline 4 & 0 & 0 & 0 & 5 & 0 & 2 & 0 & 4 & 0 & 0 \\
\hline $\mathrm{X}$ & 0 & 0 & 0 & 0 & 1 & 0 & 0 & 0 & 0 & 0 \\
\hline$\Sigma(\mathrm{db}):$ & 50 & 50 & 50 & 50 & 51 & 50 & 50 & 50 & 50 & 50 \\
\hline
\end{tabular}

\begin{tabular}{|l|l|l|l|l|l|l|l|l|l|l|}
\hline $\begin{array}{l}\text { CA 2009. } \\
\text { XI. havi }\end{array}$ & C-M & C-H & $\begin{array}{l}\text { Ke1/2- } \\
\text { M }\end{array}$ & $\begin{array}{l}\text { Ke1/2- } \\
\mathbf{H}\end{array}$ & Ke8-M & Ke8-H & $\begin{array}{l}\text { NESp- } \\
\text { M }\end{array}$ & $\begin{array}{l}\text { NESp- } \\
\text { H }\end{array}$ & $\begin{array}{l}\text { NESo- } \\
\text { M }\end{array}$ & $\begin{array}{l}\text { NESo- } \\
\text { H }\end{array}$ \\
\hline 0 & 44 & 7 & 33 & $\mathbf{2}$ & 35 & 9 & 49 & 15 & 53 & 40 \\
\hline 1 & 3 & 6 & 0 & $\mathbf{1 1}$ & 4 & 1 & 1 & 9 & 1 & 4 \\
\hline 2 & 1 & 7 & 1 & $\mathbf{4}$ & 1 & 4 & 0 & 3 & 0 & 4 \\
\hline 3 & 1 & 13 & 4 & $\mathbf{2 1}$ & 4 & 8 & 1 & 7 & 0 & 2 \\
\hline 4 & 3 & 17 & 11 & $\mathbf{1 2}$ & 7 & 28 & 1 & 16 & 0 & 2 \\
\hline X & 1 & 0 & 3 & $\mathbf{0}$ & 1 & 4 & 0 & 0 & 0 & 0 \\
\hline Össz: & 52 & 50 & 49 & $\mathbf{5 0}$ & 51 & 50 & 52 & 50 & 54 & 52 \\
\hline
\end{tabular}

\begin{tabular}{|l|l|l|l|l|l|l|l|l|l|l|}
\hline $\begin{array}{l}\text { CA 2009. } \\
\text { XII. havi }\end{array}$ & C-M & C-H & $\begin{array}{l}\text { Ke1/2- } \\
\text { M }\end{array}$ & $\begin{array}{l}\text { Ke1/2- } \\
\text { H }\end{array}$ & Ke8-M & Ke8-H & $\begin{array}{l}\text { NESp- } \\
\text { M }\end{array}$ & $\begin{array}{l}\text { NESp- } \\
\text { H }\end{array}$ & $\begin{array}{l}\text { NESo- } \\
\text { M }\end{array}$ & $\begin{array}{l}\text { NESo- } \\
\text { H }\end{array}$ \\
\hline 0 & & 0 & & 1 & & 0 & & 16 & & 37 \\
\hline 1 & & 0 & & 0 & & 1 & & 1 & & 0 \\
\hline 2 & & 1 & & 1 & & 5 & & 0 & & 2 \\
\hline 3 & & 12 & & 18 & & 9 & & 7 & & 2 \\
\hline 4 & & 34 & & 29 & & 30 & & 28 & & 6 \\
\hline $\mathrm{X}$ & & 0 & & 0 & & 0 & & 0 & & 0 \\
\hline$\Sigma(\mathrm{db}):$ & & 47 & & 49 & & 45 & & 52 & & 47 \\
\hline
\end{tabular}




\section{M12. S. caprea kontroll dugványok gyökeresedése melegtalpon és melegtalp nélküil ${ }^{4}$}
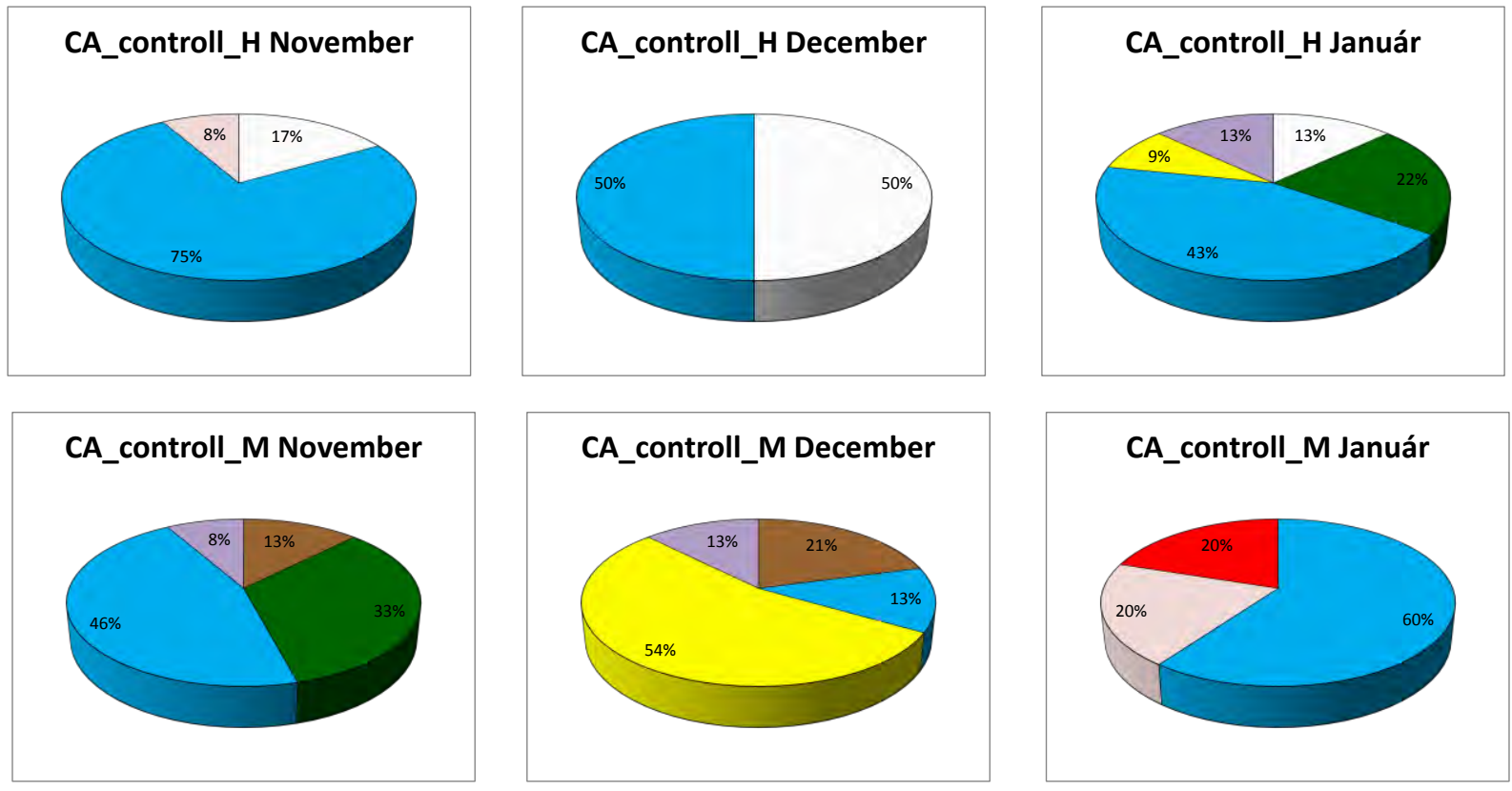

\begin{tabular}{|l|l|l|}
\hline & talpi barnulás & kalluszcsomók \& gyökérkezdemények \\
\hline & semmi változás & erős kalluszburjánzás (repedő kéreg) \\
\hline & megvastagodott alsó rész & $1-2$ gyökér \\
\hline 1-5 db kalluszcsomó & $3-4$ gyökér \\
\hline $5 \mathrm{db}<$ kalluszcsomó & $5 \leq$ gyökér \\
\hline
\end{tabular}

${ }^{4} 3$ (november, január), illetve 5 (december) héttel a dugványozást követően 


\section{M13. Kelpak ${ }^{\circledR}$-kal fél-, illetve 8 órán keresztül felszívatott $S$. caprea dugványok gyökeresedése melegtalpon és melegtalp nélkül ${ }^{5}$}
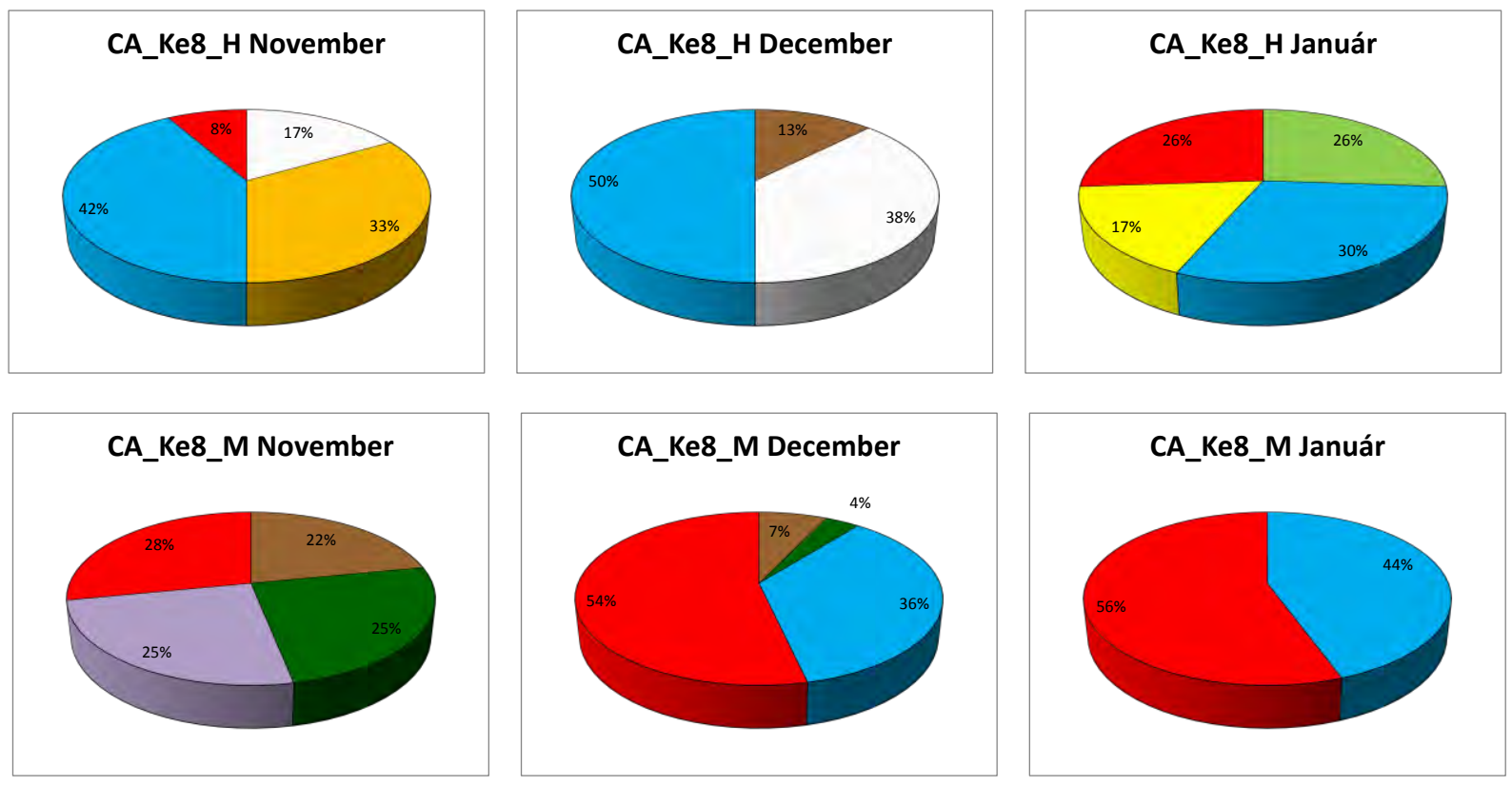

\begin{tabular}{|l|l|l|}
\hline & talpi barnulás & kalluszcsomók \& gyökérkezdemények \\
\hline & semmi változás & erős kalluszburjánzás (repedő kéreg) \\
\hline & megvastagodott alsó rész & $1-2$ gyökér \\
\hline $1-5 \mathrm{db}$ kalluszcsomó & $3-4$ gyökér \\
\hline $5 \mathrm{db}<$ kalluszcsomó & $5 \leq$ gyökér \\
\hline
\end{tabular}
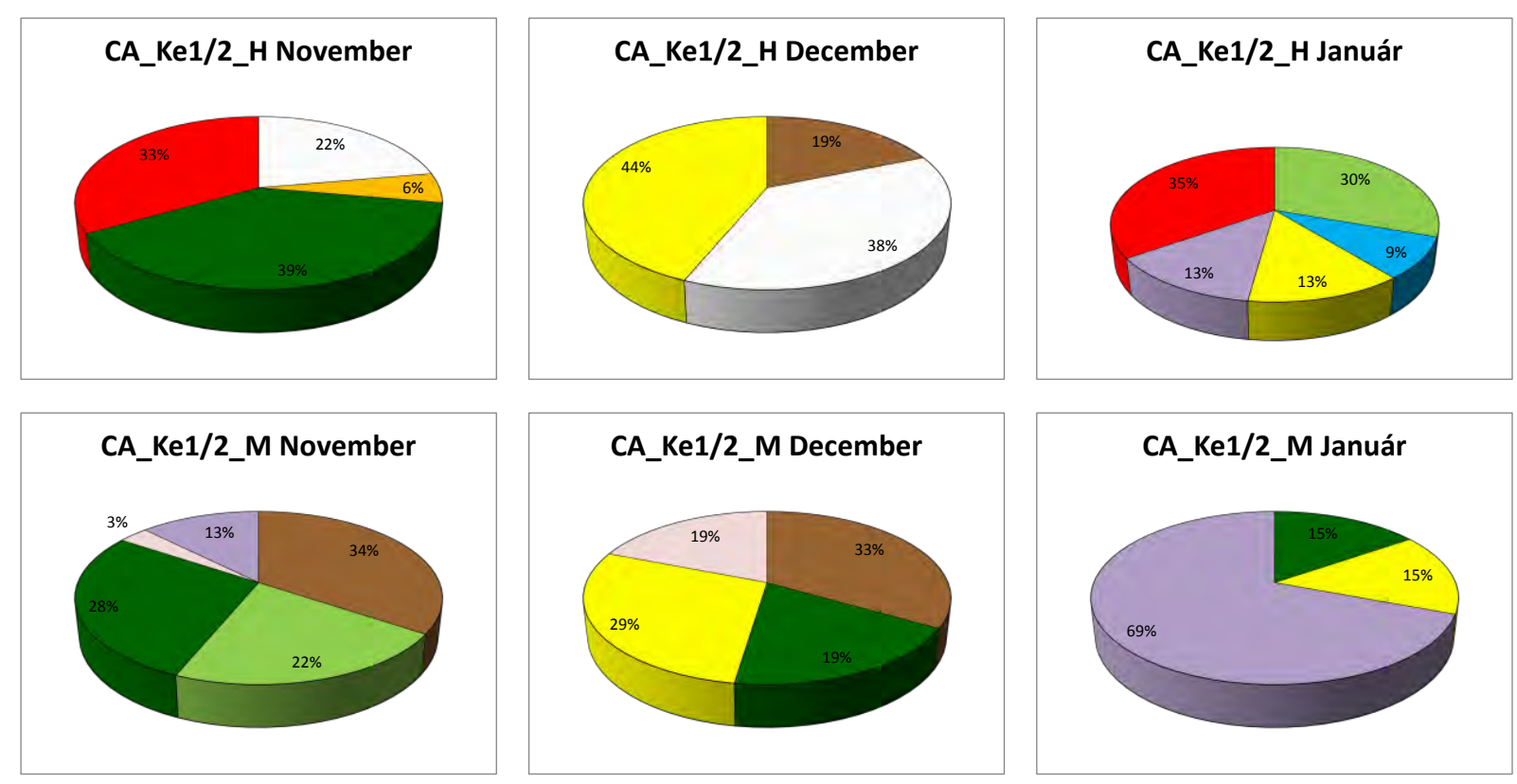

${ }^{5} 3$ (november, január), illetve 5 (december) héttel a dugványozást követően 


\section{M14. 6 \%o naftil-ecetsavval alkoholos oldat és por formátumban kezelt $S$. caprea dugványok gyökeresedése melegtalpon ${ }^{6}$}
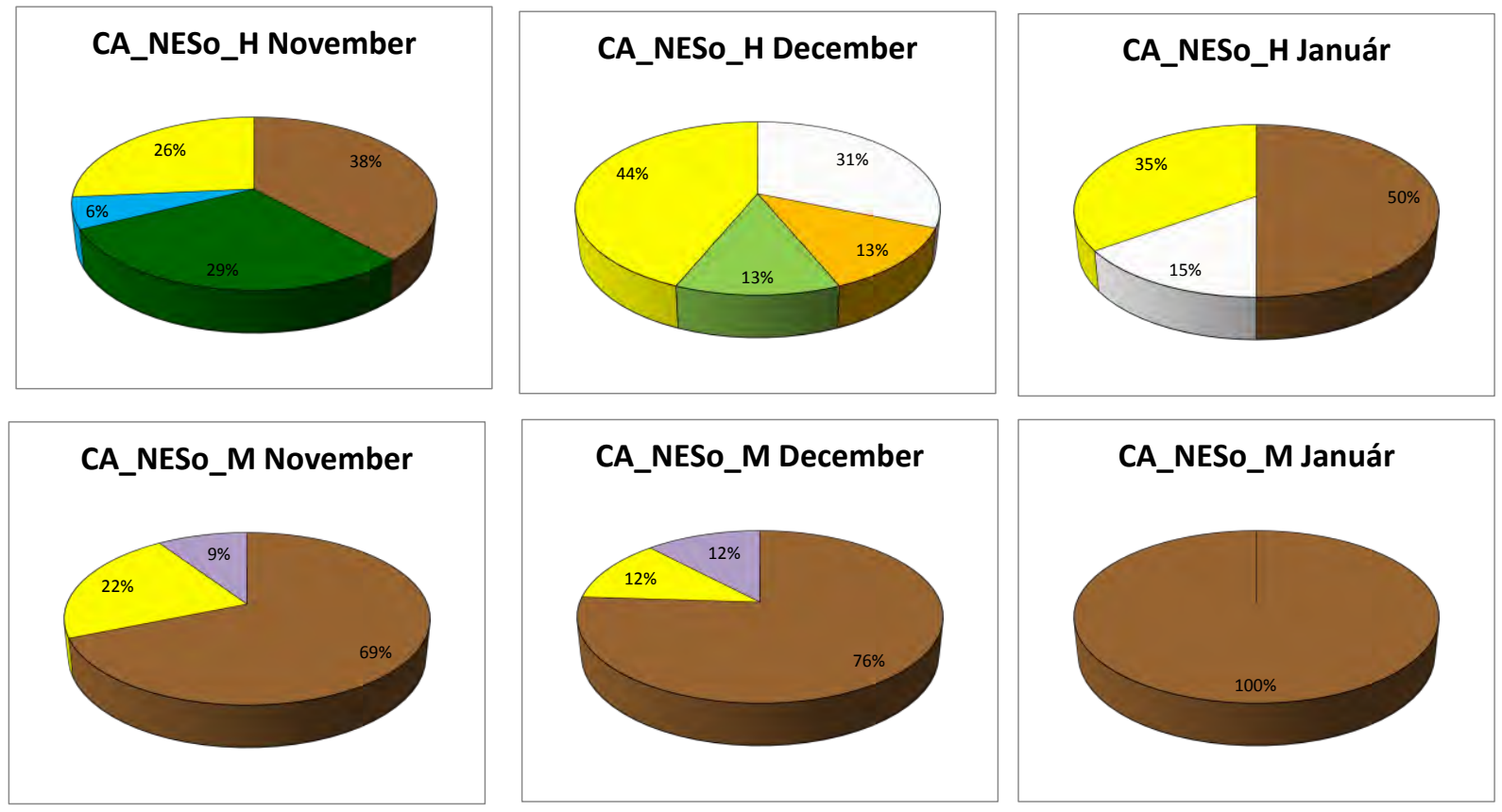

\begin{tabular}{|c|c|}
\hline talpi barnulás & kalluszcsomók \& gyökérkezdemények \\
\hline semmi változás & erős kalluszburjánzás (repedő kéreg) \\
\hline megvastagodott alsó rész & 1-2 gyökér \\
\hline 1-5 db kalluszcsomó & 3-4 gyökér \\
\hline $5 \mathrm{db}<$ kalluszcsomó & $5 \leq$ gyökér \\
\hline
\end{tabular}
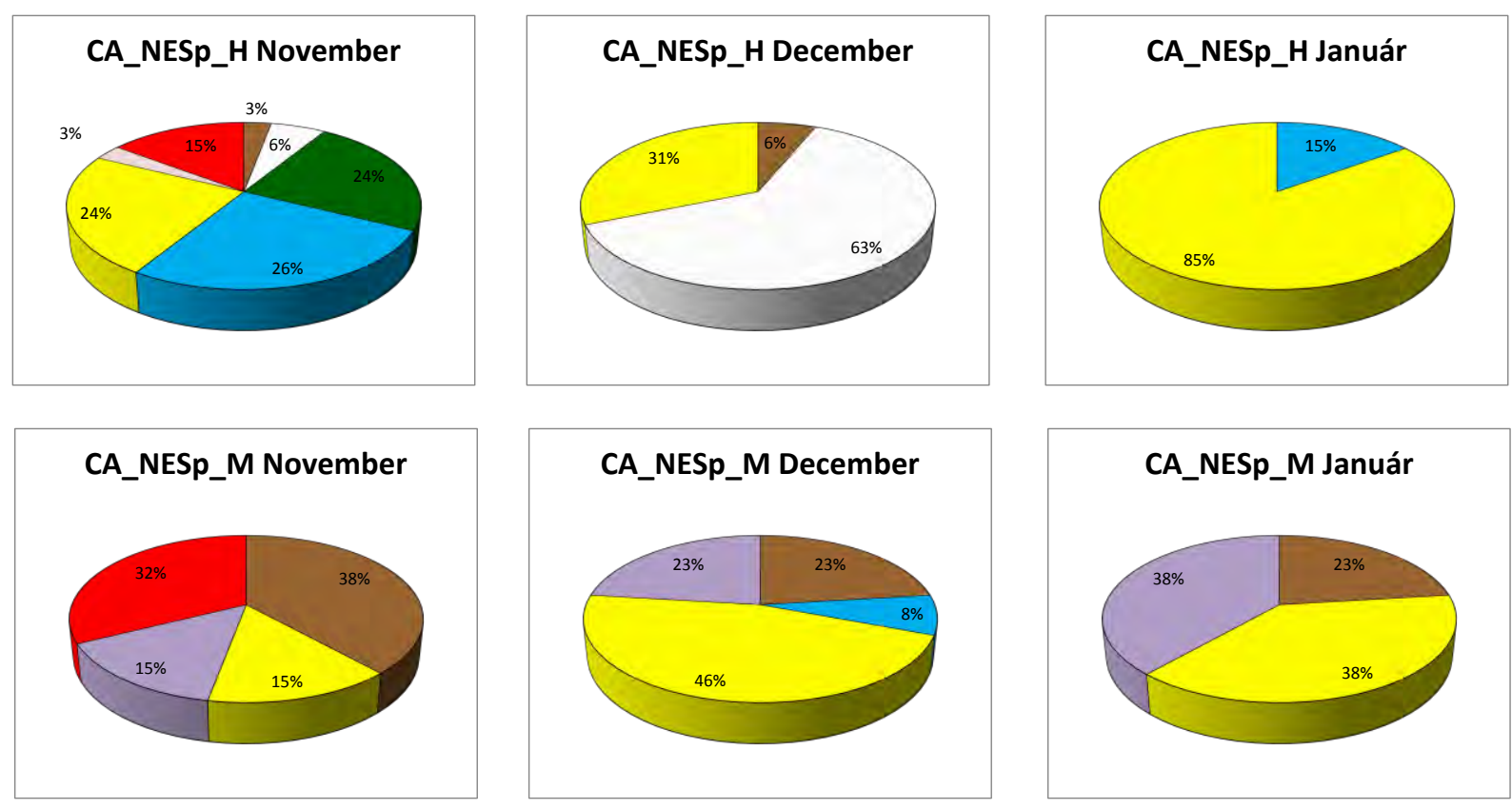

${ }^{6} 3$ (november, január), illetve 5 (december) héttel a dugványozást követően 


\section{M15. S. rosmarinifolia kontroll dugványok gyökeresedése melegtalpon és melegtalp nélkül ${ }^{7}$}
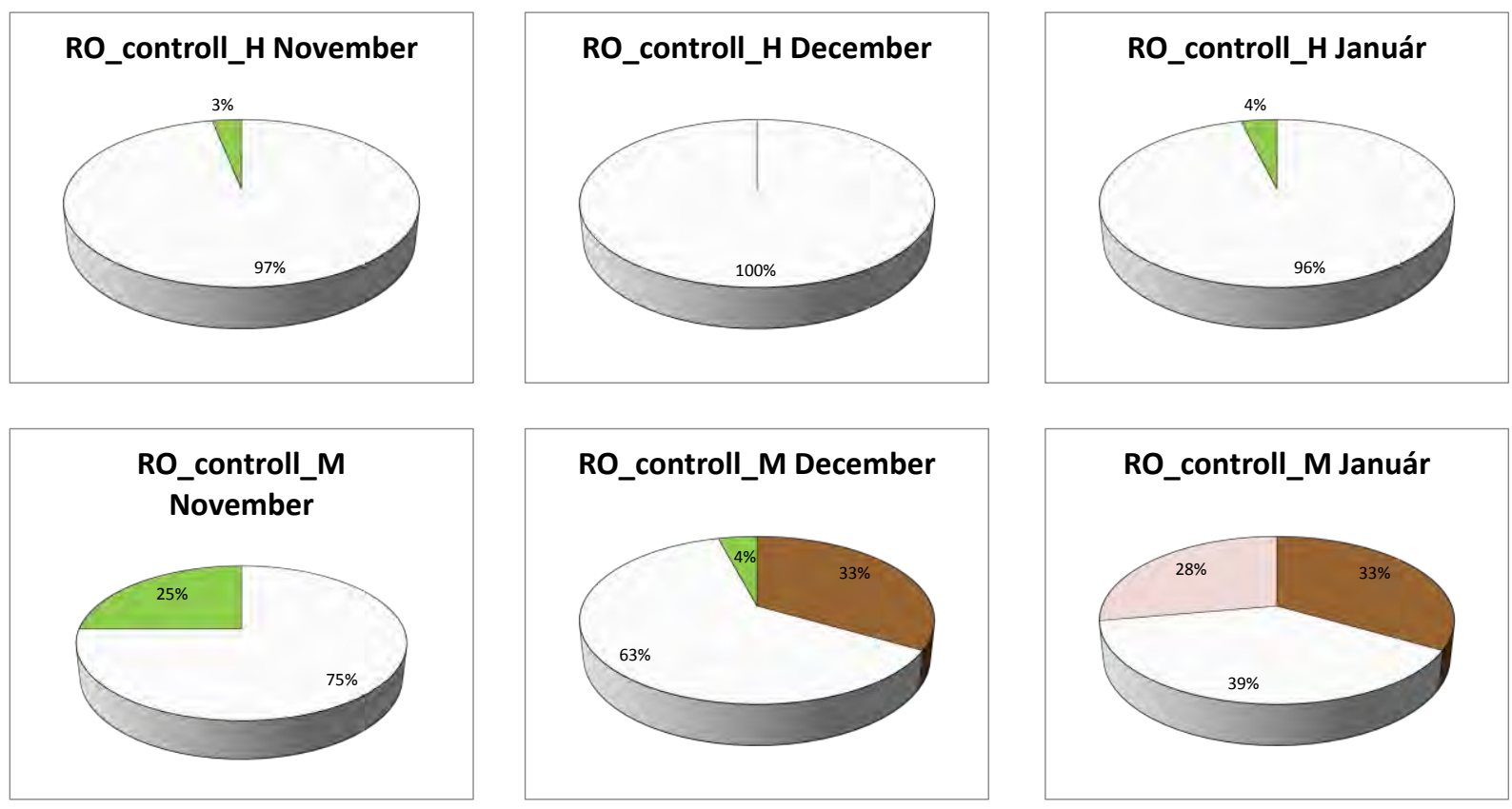

\begin{tabular}{|c|c|}
\hline talpi barnulás & kalluszcsomók \& gyökérkezdemények \\
\hline semmi változás & erős kalluszburjánzás (repedő kéreg) \\
\hline megvastagodott alsó rész & 1-2 gyökér \\
\hline 1-5 db kalluszcsomó & 3-4 gyökér \\
\hline $5 \mathrm{db}<$ kalluszcsomó & $5 \leq$ gyökér \\
\hline
\end{tabular}

${ }^{7} 3$ (november, január), illetve 5 (december) héttel a dugványozást követően 


\section{M16. Kelpak ${ }^{\circledR}$-kal fél-, illetve 8 órán keresztül felszívatott $S$. rosmarinifolia dugványok gyökeresedése melegtalpon és melegtalp nélküil ${ }^{8}$}
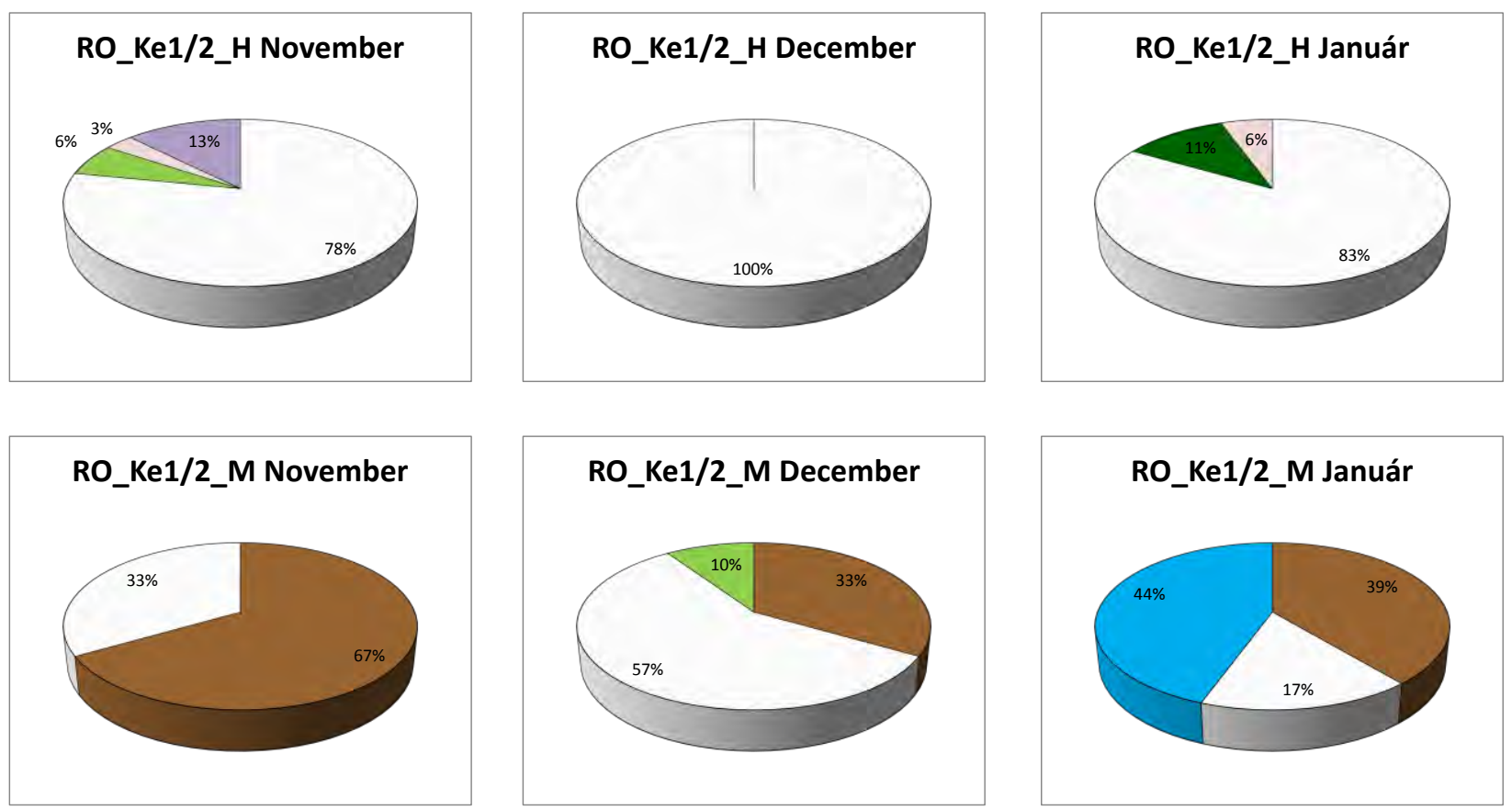

\begin{tabular}{|l|l|l|}
\hline & talpi barnulás & kalluszcsomók \& gyökérkezdemények \\
\hline semmi változás & erős kalluszburjánzás (repedő kéreg) \\
\hline megvastagodott alsó rész & $1-2$ gyökér \\
\hline 1 - $5 \mathrm{db}$ kalluszcsomó & 3 -4 gyökér \\
\hline $5 \mathrm{db}<$ kalluszcsomó & $5 \leq$ gyökér \\
\hline
\end{tabular}
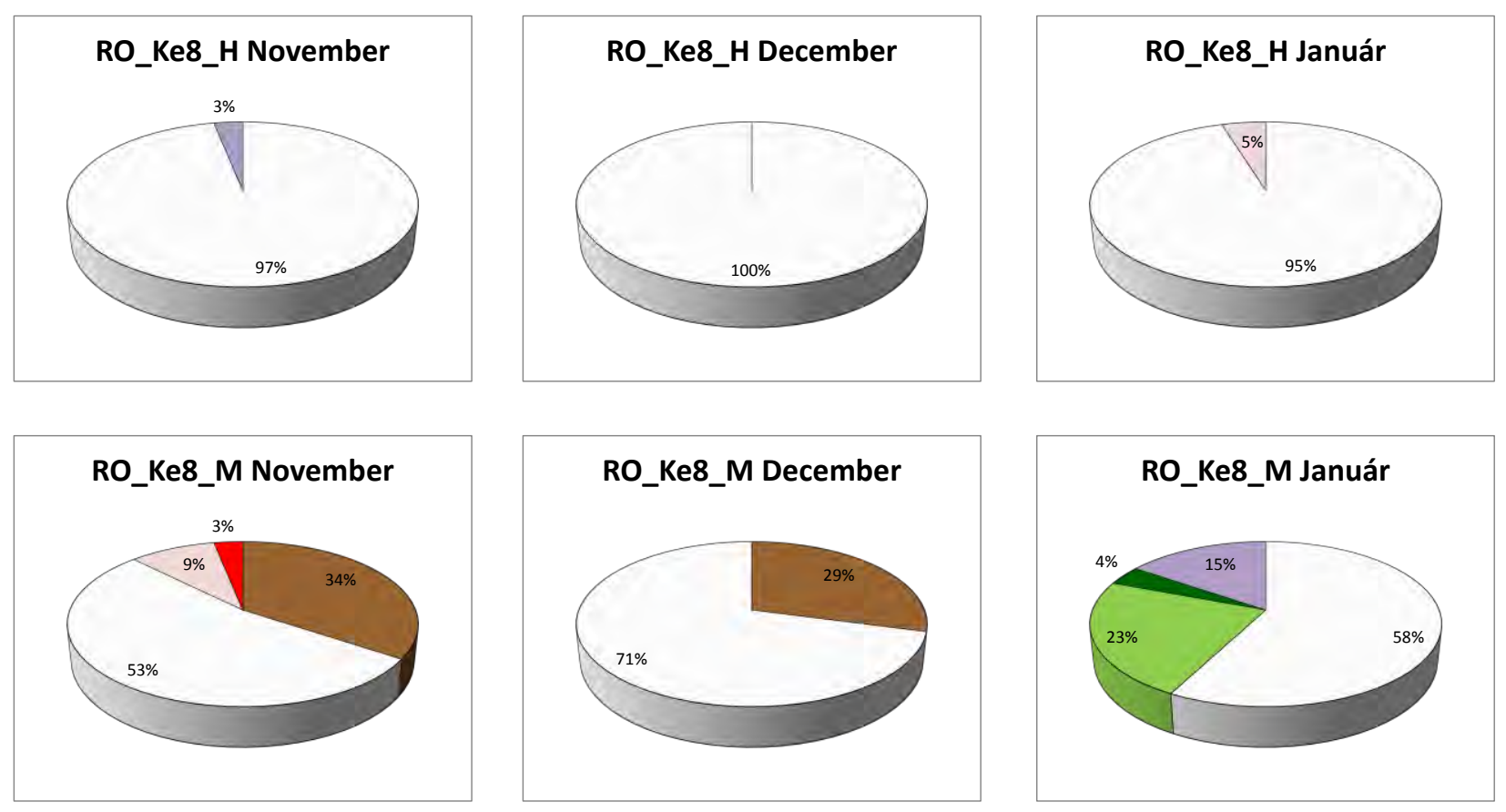

${ }^{8} 3$ (november, január), illetve 5 (december) héttel a dugványozást követően 


\section{M17. 6 \%o naftil-ecetsavval alkoholos oldat és por formátumban} kezelt $S$. rosmarinifolia dugványok gyökeresedése melegtalpon és melegtalp nélkül'
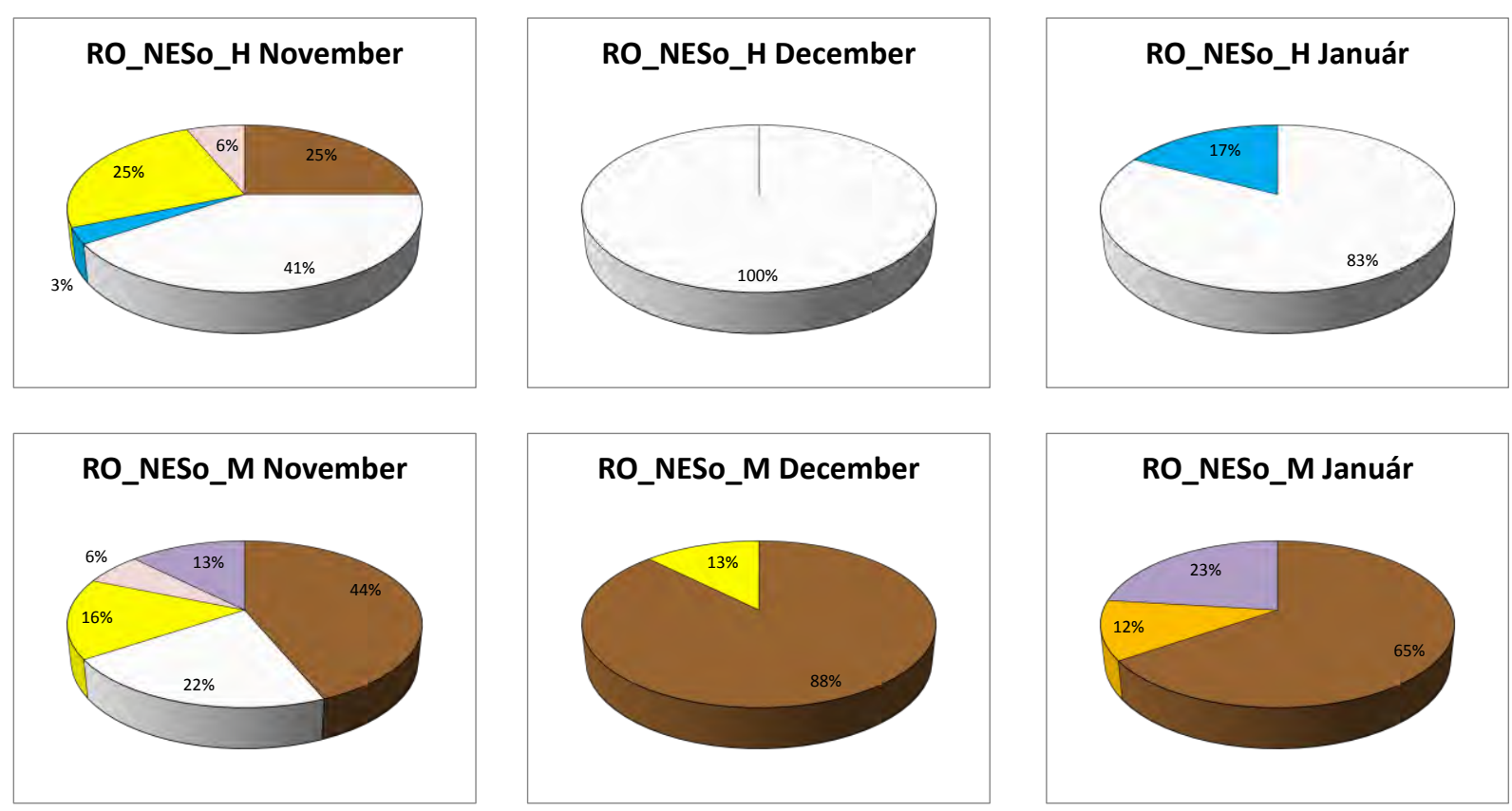

\begin{tabular}{|l|l|l|}
\hline & talpi barnulás & kalluszcsomók \& gyökérkezdemények \\
\hline & semmi változás & erős kalluszburjánzás (repedő kéreg) \\
\hline megvastagodott alsó rész & $1-2$ gyökér \\
\hline $1-5 \mathrm{db}$ kalluszcsomó & 3 -4 gyökér \\
\hline $5 \mathrm{db}<$ kalluszcsomó & $5 \leq$ gyökér \\
\hline
\end{tabular}
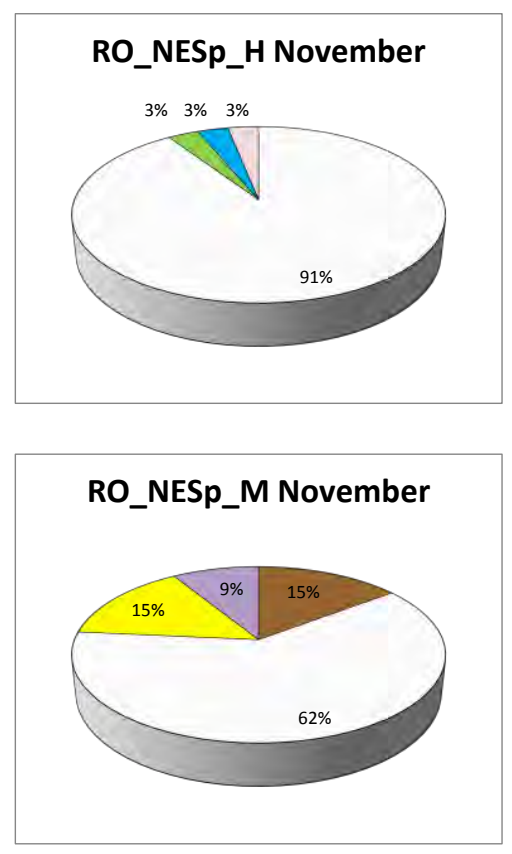
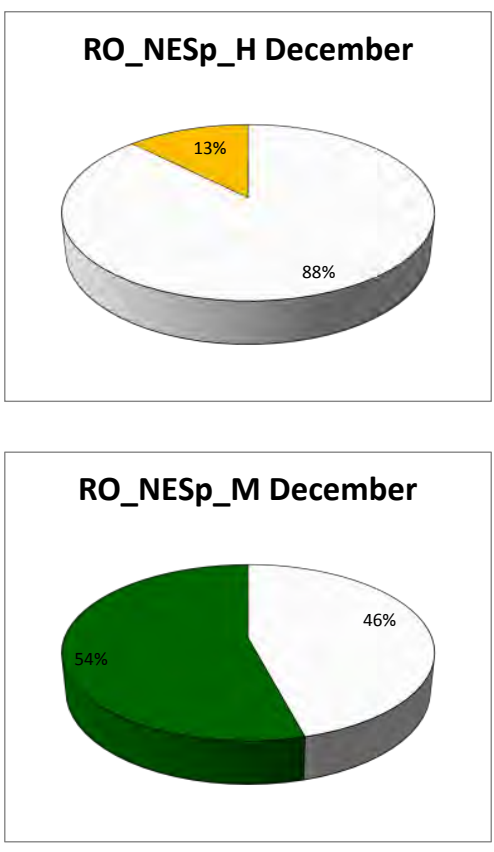

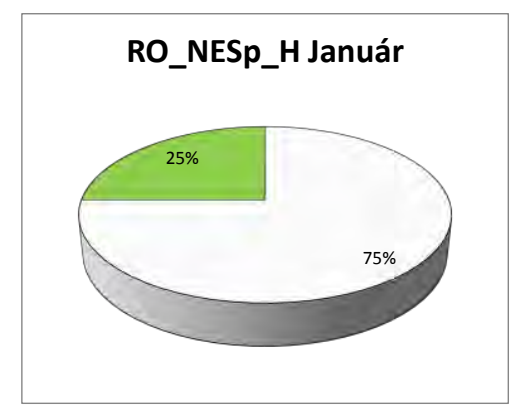

RO_NESp_M Január

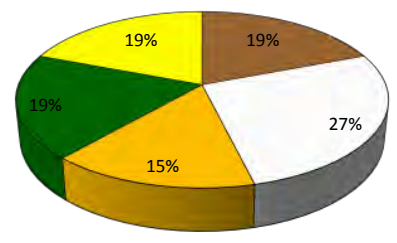

${ }^{9} 3$ (november, január), illetve 5 (december) héttel a dugványozást követően 


\section{M18. Salix caprea és $S$. rosmarinifolia víztartalmának és Z- értékének meghatározása}

\begin{tabular}{|c|c|c|c|}
\hline S. rosmarinifolia köteg töme & ge felszívatás előt & & 8,13 \\
\hline S. rosmarinifolia taxon friss & víztartalma & & 0,493401 \\
\hline Vizsgált köteg friss víztartal & $\mathrm{ma}(\mathrm{g})$ & & 4,0113503 \\
\hline & sürüsége $\left(\mathrm{g} / \mathrm{cm}^{3}\right)$ & térfogata $\left(\mathrm{cm}^{3}\right)$ & tömege $(\mathrm{g})$ \\
\hline glicerin & 1,261 & 10 & 12,61 \\
\hline víz & 0,998 & 10 & 9,98 \\
\hline felszívató oldat & 1,188947368 & 19 & 22,59 \\
\hline térfogatszázaléka: & & 526315789 & \\
\hline tömegszázaléka: & & 558211598 & \\
\hline Felvett mennyiség $(\mathrm{g})$ : & 1,188947368 & 6 & 7,1336842 \\
\hline Felvett glicerin mennyisége: & 3,982105263 & (felvett ele & y tömege * \\
\hline Z-érték: & 0,99270944 & & aléka) \\
\hline
\end{tabular}

$\rightarrow$ Azaz a gyöngybarka friss víztartalmának 99\%-a cserélődött ki glicerinre.

\begin{tabular}{|c|c|c|c|}
\hline S. caprea köteg tömege felsz & zívatás előtt $(\mathrm{g})$ & & 49,85 \\
\hline S. caprea taxon friss víztarta & alma & & 0,6383588 \\
\hline Vizsgált köteg friss víztartal & $\mathrm{ma}(\mathrm{g})$ & & 31,822185 \\
\hline & sürüsége $(\mathrm{g} / \mathrm{cm} 3)$ & $\begin{array}{l}\text { térfogata } \\
(\mathrm{cm} 3)\end{array}$ & tömege $(\mathrm{g})$ \\
\hline glicerin & 1,261 & 50 & 63,05 \\
\hline víz & 0,998 & 100 & 99,8 \\
\hline felszívató oldat & 1,085666667 & 150 & 162,85 \\
\hline térfogatszázaléka: & & 33333333 & \\
\hline tömegszázaléka: & & 87166104 & \\
\hline Felvett mennyiség: & 1,085666667 & 15 & 16,285 \\
\hline $\begin{array}{l}\text { Felvett glicerin mennyisége: } \\
\text { Z-érték: }\end{array}$ & $\frac{6,305}{0,198132214}$ & $\begin{array}{l}\text { (felve } \\
\text { elegy }\end{array}$ & $\begin{array}{l}\text { gy tömege * } \\
\text { gszázaléka) }\end{array}$ \\
\hline
\end{tabular}

$\rightarrow$ Azaz a barkás vesszők friss víztartalmának 20\%-a cserélődött ki glicerinre.

$\mathrm{Z}=($ felvett oldat * glicerines oldat tömegszázaléka)/(tartósítandó növény friss tömege * adott növény víztartalma\%-ban) 


\section{KÖSZÖNETNYILVÁNÍTÁS}

Ezúton szeretném megköszönni konzulensem, Tillyné Dr. Mándy Andrea egyetemi docens támogatását, türelmét, segítő tanácsait a dolgozat elkészítésével kapcsolatban. Köszönöm Dr. Schmidt Gábor professzor úrnak, hogy mindvégig segítő figyelemmel kísérte kutatásaimat, és sok hasznos tanácsot és javaslatot kaptam tőle. Hálás köszönet illeti Dr. Szabóné Dr. Erdélyi Éva egyetemi adjunktust az eredmények statisztikai próbákkal történő vizsgálatáért, a statisztikai programcsomagok használatában nyújtott áldozatkész segítségéért. Köszönöm Dr. Szalai József tanár úrnak a növényélettan területén folytatott konzultációkat. A fizikával, mechanikával kapcsolatos konzultációkért hálás köszönetem Dr. Láng Zoltán professzor úrnak, a Müszaki Tanszék tanszékvezetőjének; Dr. Dobos Lászlónak, az ELTE fizikusának, és Dr. Vozáry Eszter tanárnőnek, a Fizika-Automatika Tanszék munkatársának. Köszönöm Dr. Csapó Gyula egyetemi adjunktusnak, a gödöllői Szent István Egyetem Gépészmérnöki Karán a Géptani Intézet munkatársának a szakítógép bemutatását, a kézi erőmérők kölcsönzését, és a témában folytatott konzultációkat. Nagyon köszönöm a Rovartani Tanszék munkatársainak; Dr. Mészáros Zoltán, Dr. Haltrich Attila és Dr. Vétek Gábor tanár uraknak a füz fajok kártevőinek meghatározásában nyújtott segítségét. Köszönöm a hazai fás szárú vágott virág termesztőknek: Varjú Ákosnak és Csillának (C\&L Flora Kft., Szolnok); Krausz Tamásnak (Mór); és Zajcsek Szabolcsnak (Csemeteplussz Erdészeti Faiskola, Egeralja), hogy bemutatták ültetvényeiket, és megosztották tapasztalataikat. Köszönöm a gyüjtőknek, különösen Dabasról Sikari Jánosnak és családjának, hogy megosztották velem tapasztalataikat. Köszönöm Dr. Reményi Mária Lujza egyetemi adjunktus munkáját; a gyökeresedés, a füzérvirágzatok, és a vesszők morfológiáját és anatómiáját bemutató, sztereo- és fénymikroszkópos felvételek elkészítését. Köszönöm a Soroksári Kísérleti Üzem és Tangazdaság, Dísznövény Ágazat munkatársainak, különösen Dr. Fekete Szabolcsnak, Feró Ágnesnek, és Kovács Zitának a segítségét a kísérleti növények, a dugványok, és a becserepezett növények gondozásában. Köszönöm Gyurcs Andreának, a Dísznövénytermesztési és Dendrológiai Tanszék laboránsának az adatok rögzítésében nyújtott sok segítséget a tartóssági kísérlet több ezer mérésénél. Köszönöm Dobos Katalinnak és Lambert Attilának a Soroksáron kiültetett növényekröl készített felvételeket, Treer Andrásnak az esseni virágkiállításon és a Flora Hungaria virágpiacon készített, Salix vesszőket bemutató professzionális minőségü fényképeket. Hálásan köszönöm József testvérem áldozatkész segítségét a dolgozat szerkesztésében, a Word számtalan alkalmazásának megismertetésében. Végül, de nem utolsósorban végtelenül hálásan köszönöm családomnak, elsősorban szüleimnek, hogy közel tíz éven keresztül megadtak minden támogatást, hogy kutatásaimat minél zavartalanabbul folytathassam, és a dolgozatot végül befejezhessem. Köszönöm gyermekeimnek, Borbálának és Virágnak angyali türelmüket. 